\author{
UNIVERSIDADE DE SÃO PAULO \\ ESCOLA DE ENGENHARIA DE SÃO CARLOS \\ DEPARTAMENTO DE HIDRÁULICA E SANEAMENTO
}

DAYANE MENDES BONI

Avaliação da Viabilidade de Cistos de Giardia spp. e Oocistos de Cryptosporidium parvum em Água Filtrada Obtida Após Tratamento Convencional com Flotação e Ozonização

VERSÃO CORRIGIDA

São Carlos - SP

2016 


\title{
Avaliação da Viabilidade de Cistos de Giardia spp. e Oocistos de Cryptosporidium parvum em Água Filtrada Obtida Após Tratamento Convencional com Flotação e Ozonização
}

\author{
Dissertação apresentada à \\ Escola de Engenharia de São Carlos, \\ da Universidade de São Paulo, como \\ parte dos requisitos para obtenção do \\ título de Mestre em Ciências: \\ Engenharia Hidráulica e Saneamento.
}

Orientadora: Prof. ${ }^{a}$ Dr. ${ }^{a}$ Lyda Patrícia Sabogal Paz 
AUTORIZO A REPRODUCCÃO TOTAL OU PARCIAL DESTE TRABALHO, POR QUALQUER MEIO CONVENCIONAL OU ELETRONNICO, PARA FINS DE ESTUDO E PESQUISA, DESDE QUE CITADA A FONTE

Boni, Dayane Mendes

B715u Uso de Oronio na Inativaça de Giardia spp. e Cryptosporidium parvum Presentes na Agua Filtrada Obtida Apos Tratamento Convencional com Flotaclo / Dayane Vendes Boni; orientadora Iyda Patricia Sabogal Dayane Kendes

Dissertaçalo (Mestrado) - Programa de Pos-Graduaçlo en Engenharia Hidrkulica e Saneamento e Area de Concentraço em Hidraulica e Sanemento -- Escola de Engenharia de SAo Carlos da Universidade de SHo Paulo, 2016 .

1. Giardia spp.. 2. Cryptosporidiun parvun. 3. desinfecçlo de agua. 4. ozônio. 5. flotaç\$o. 6. PAC. 7. floculaç̌lo en carbonato de cálcio. 8. separaçăo imunomagnetica. I. Titulo. 


\section{FOLHA DE JULGAMENTO}

\section{Candidata: Bacharela DAYANE MENDES BONI.}

Título da dissertaçāo: "Uso de ozônio na inativaçåo de Giardía spp. e Cryptosporidium paryum presentes na agua filtrada obtida após tratamenlo convencional com flotaçäo.

Dato da detesa: 09/09/2016.

\section{Comissào Jukgadora:}

Profa. Dra. Lyda Pairicia Sabogal Paz

(Orlentadora)

[Escola de Engenharia de Sāo Carlos/EESC]

Frofa. Dra. Jeonette Beber de Souzo

[Universidade Estadual do Centro-Oosto/UNICENTRO)

Prof. Dr. José Roberto Guimarães

(Universidade Estadual de Campinas/UNICAMP)

\section{Resultado:}

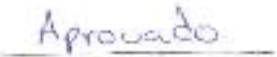

Aprovado

APROMAOT

Coordenadora do Programu de Pós-Graduoção em Engenharia Hidrćulica e Saneamento:

Prola. Associada Maria Bernadete A. Varesche Silva

Presidente da Comissāo de Pós-Graduaçōo:

Proí. Associodo Luis Fernando Costa Alberto 


\section{AGRADECIMENTOS}

Primeiramente, agradeço à Deus pela minha vida e pelo belo caminho traçado até aqui, pelas boas escolhas, saúde, fé, aprendizado, infinitas alegrias e coragem nos momentos de dificuldade;

Aos meus pais, Cleide e Valcir, pelo amor e apoio incondicional que sempre me proporcionaram, por quem tenho imenso orgulho e eterna gratidão. Agradecerei sempre pelos incentivos, educação, carinho e conselhos que guiaram e sempre guiarão meus passos. A vocês, todo o amor do mundo;

Ao meu irmão Renan, meu fiel escudeiro, amigo e companheiro de todas as horas. Obrigada por todas as ajudas, brincadeiras e conselhos;

À toda a minha família, em especial aos meus avós maternos, vó Amandia e vô Saturnino (em memória) e aos avós paternos, vó Alexandrina e vô Ernesto (em memória) por todos os momentos vividos, por todo carinho compartilhado, conversas e conselhos, pessoas de caráter e de coração puro, por quem tenho amor imensurável;

À minha orientadora, Prof. ${ }^{a}$ Dr. ${ }^{a}$ Lyda Patricia Sabogal Paz, por quem tem enorme respeito, pela pessoa e profissional que é, sempre atenciosa, solícita e presente em todos os momentos da pesquisa. Obrigada pela paciência, dedicação, ajuda e orientação em todas as etapas;

Ao Professor Luiz Antonio Daniel, pela ajuda com o ozonizador e ao Professor Marco Antonio Penalva Reali por ceder o LATAR para realização da pesquisa;

À técnica de laboratório do LATAR, Maria Teresa, pela ajuda nas análises e preparo dos reagentes, pela amizade e conversas; ao técnico Júlio por contribuir com as análises de metais e ao Alcino, pessoa sempre agradável que solucionou diversos problemas sempre que necessário;

Às professoras Regina Maura e Luciana Urbano e ao técnico biólogo Nilson Branco do Instituto de Biologia da UNICAMP pela ajuda com as dúvidas no decorrer da pesquisa e pelas suspensões de protozoário;

Aos amigos e companheiros LATARIANOS, Fernanda, Juliana, Fernando, Gabriela, Eloá, Guilherme, Paulo, Marcon, Pri, Rodrigo, Ana, Gabriel, Aline, Thadeu, Bárbara, Ulisses e Arroz pelos momentos de alegria, conversas e distração;

Ao Guilherme Giglio pela ajuda no início da pesquisa e ao Fernando Andreoli, companheiro na parte inicial do trabalho;

Ao Rodrigo Vieira pelos dados cedidos da calibração do ozonizador;

Ao Willame Cavalcante pela ajuda com as análises estatísticas;

Às amizades conquistadas em São Carlos e que sempre levarei comigo: Quixera, Tupete, Lombardi, Pariconha, Carolzinha, Alecrim, Gabriel, Cebola, Pauleta, Gui, Paulo, Elaias e a todos que aqui conheci;

Ao grupinho de amigas que deixou o Latar e a vida mais leve: Fernanda, Gabriela, Juliana e Eloá, vocês são as minhas lindezas, obrigada pela amizade e por todos os momentos; 
À Fernanda Valdez, minha companheira da faculdade, do mestrado e da vida, uma pessoa incrível que tenho a alegria de ter amizade. Obrigada por tudo;

Ao Rafael Novais, meu amigo mais que especial, uma pessoa maravilhosa, por quem tenho muito carinho e alegria de compartilhar os momentos;

À República Sheidy, que foi e sempre será minha segunda família da graduação em Irati: Mylena, Moara e Fernanda. Pensem num quarteto inseparável, amo vocês. E a todos os amigos da faculdade;

Aos meus amigos de infância e para a vida toda: Patrícia, Moara, Felipe e Natiélli. Aqui tem amizade sincera e muito amor envolvido;

À Escola de Engenharia de São Carlos e ao Departamento de Hidráulica e Saneamento pela oportunidade de realizar o mestrado;

À Sá, Priscila e Rose, secretarias do departamento, pela atenção e informações;

À Empresa Quimisa S/A por fornecer o coagulante cloreto de polialumínio (PAC) necessário

à pesquisa;

Ao CNPQ pela bolsa concedida e à FAPESP pelo suporte financeiro concedido no projeto temático no 2012/50522-0 "Contaminação ambiental pelos protozoários Giardia spp. e Cryptosporidium spp. e por Ascaris suum: desafios de detecção, remoção e inativação das formas infectantes". 
"Não se preocupe com a perfeição. Substitua a palavra "perfeição" por "totalidade". Não pense que você tem de ser perfeito, Pense que tem de ser total. A totalidade dá a você uma dimensão diferente." 


\section{RESUMO}

BONI, D. M. (2016). Avaliação da Viabilidade de Cistos de Giardia spp. e Oocistos de Cryptosporidium parvum em Água Filtrada Obtida Após Tratamento Convencional com Flotação e Ozonização. Dissertação (Mestrado). Escola de Engenharia de São Carlos, Universidade de São Paulo, São Carlos, 2016.

Esta pesquisa avaliou o uso de ozônio para inativar cistos de Giardia spp. e oocistos de Cryptosporidium parvum presentes na água filtrada obtida após a utilização da tecnologia de ciclo completo com flotação (coagulação, floculação, flotação e filtração) em escala de bancada, empregando o cloreto de polialumínio - PAC como coagulante. O método de floculação em carbonato de cálcio - FCCa, sem e com a etapa de separação imunomagnética - IMS foi utilizado na quantificação dos protozoários. A recuperação nos ensaios de qualidade utilizando o kit Easyseed ${ }^{\circledR}$ de Giardia spp. foi de 8,4\% \pm 97,4\% sem IMS e com IMS, com duas dissociações, o valor foi de 7,4\% $\pm 39,7 \%$ e, com três dissociações, a recuperação alcançou 9,6\% $\pm 34,7 \%$, portanto, somente o ensaio com IMS e duas dissociações, não atendeu os padrões do Método 1623.1. A recuperação de Cryptosporidium parvum, obteve valor de $3,4 \% \pm 100 \%$ em ensaio sem IMS e com IMS, o valor obtido foi de $1,0 \% \pm 70,0 \%$ com duas dissociações e $1,8 \% \pm 44,4 \%$ com três dissociações e nos três métodos apresentados, não houve conformidade com os critérios do Método 1623.1. Na etapa de desinfecção com ozônio, os ensaios realizados na Etapa 1, que se utilizou $5 \mathrm{mgO}_{3} \mathrm{~L}^{-1} \mathrm{e}$ tempo de contato de 1 min sem IMS, as maiores inativações atingidas foram de 2,52 e 2,22 log para cistos de Giardia spp. e oocistos de Cryptosporidium parvum, respectivamente. Com o tempo de contato de $5 \mathrm{~min}$, as maiores inativações foram de 2,52 e 2,92 log de cistos de Giardia spp. e oocistos de Cryptosporidium parvum, respectivamente. Na Etapa 2, com IMS, utilizando a mesma dosagem e tempo de contato de 1 min, obteve-se 2,27 e 0,21 log de inativação para cistos e oocistos, respectivamente. Comparando-se com o tempo de contato de 5 min, foram obtidos 2,9 e 2,3 log de inativação para cistos e oocistos, respectivamente. $\mathrm{Na}$ avaliação de custo, o método de FCCa sem IMS demonstrou ser o mais econômico em relação ao procedimento com IMS. A influência da inclusão da terceira dissociação ácida no método com IMS também foi analisada e este procedimento não resultou em diferenças estatísticas significativas nos resultados.

Palavras-chave: Giardia spp.; Cryptosporidium parvum; desinfecção de água; ozônio; PAC; floculação em carbonato de cálcio; separação imunomagnética - IMS. 


\begin{abstract}
BONI, D. M. (2016). Viability Assessment of Giardia spp. Cysts and Cryptosporidium parvum Oocysts in Filtered Water Obtained After Conventional Treatment With Flotation and Ozonation. Dissertação (Mestrado). Escola de Engenharia de São Carlos, Universidade de São Paulo, São Carlos, 2016.
\end{abstract}

This research evaluated the use of ozone to inactivate Giardia spp. cysts and Cryptosporidium parvum oocysts present in the filtered water obtained after the use of the complete cycle of flotation technology (coagulation, flocculation, flotation and filtration) on a bench scale employing polyaluminium chloride - PAC as coagulant. The calcium carbonate flocculation method - FCCa, without and with immunomagnetic separation step - IMS has been used in the quantification of protozoa. The recovery in quality test using the kit Easyseed $^{\circledR}$ for Giardia spp. was $8.4 \% \pm 97.4 \%$ non-IMS and IMS with two dissociations, the value was $7.4 \% \pm 39.7 \%$ and with three dissociations, the recovery reached $9.6 \% \pm 34,7 \%$, so only the test with IMS and two dissociations, did not meet the standards of method 1623.1. Recovery of Cryptosporidium parvum obtained value of $3.4 \% \pm 100 \%$ in non-IMS and IMS testing, the value obtained was $1.0 \% \pm 70.0 \%$ with two dissociations and $1.8 \% \pm 44.4 \%$ with three dissociations and the three methods presented, there was non-compliance with the criteria of Method 1623.1. In step disinfection with ozone, tests performed in Step 1 was used $5 \mathrm{mgO}_{3} \mathrm{~L}^{-1}$ and contact time of $1 \mathrm{~min}$ without IMS, the major inactivation achieved were 2.52 and $2.22 \log$ for Giardia spp. cysts and Cryptosporidium parvum oocysts, respectively. With 5 minutes of contact time, the greater inactivation were 2.52 and $2.92 \log$ for Giardia spp. cysts and Cryptosporidium parvum oocysts, respectively. In Step 2, with IMS, using the same dose and 1 min contact time, there was obtained 2.27 and 0.21 log inactivation for cysts and oocysts, respectively. Compared with the 5 min of contact time, were obtained 2.9 and $2.3 \log$ inactivation for cysts and oocysts, respectively. In evaluating cost, the FCCa method without IMS proved to be the most economical in relation to the procedure with IMS. The influence of inclusion of the third acid dissociation method in IMS was also analyzed and this procedure did not result in statistically significant differences in the results.

Keywords: Giardia spp.; Cryptosporidium parvum; water disinfection; ozone; PAC; flocculation of calcium carbonate; immunomagnetic separation - IMS. 


\section{LISTA DE TABELAS}

Tabela 1: Valores utilizados para a calibração do ozonizador. 78

Tabela 2: Produção de ozônio obtida através da tensão do ozonizador e da vazão aplicada no

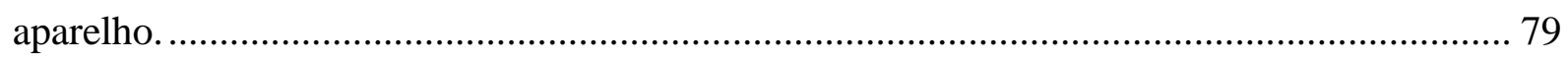

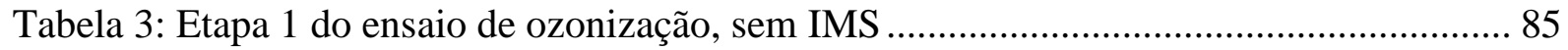

Tabela 4: Etapa 2 do ensaio de ozonização, com IMS........................................................... 85

Tabela 5: Valores obtidos da dosagem de caulinita e ácido húmico ...................................... 90

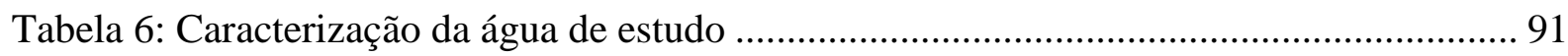

Tabela 7: Parâmetros fixados para a construção do diagrama de coagulação ......................... 92

Tabela 8: Melhores valores obtidos a partir do diagrama de coagulação ............................... 95

Tabela 9: Parâmetros definidos após a otimização do tratamento de ciclo-completo com

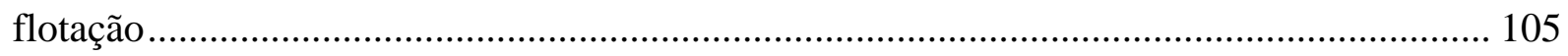

Tabela 10: Características da turbidez e da cor ao longo do tratamento............................... 106

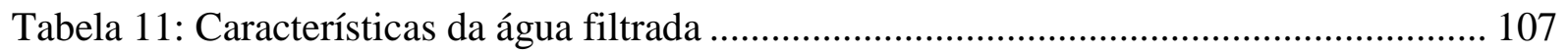

Tabela 12: Resultados dos testes 1 e 2 do Método 1 AT ....................................................... 108

Tabela 13: Resultado da contagem de Giardia lamblia ( $5 \mu \mathrm{L}$ em cada poço) para a realização

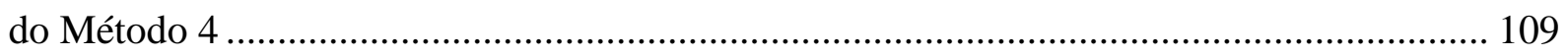

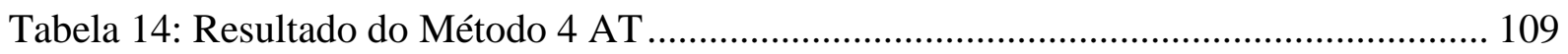

Tabela 15: Resultado dos testes obtidos para a suspensão de Giardia lamblia e Cryptosporidium parvum

Tabela 16: Resultado da leitura em triplicata das lâminas de Giardia spp. e Cryptosporidium parvum

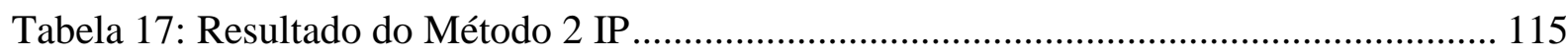

Tabela 18: Resultado do Método 3 IP ............................................................................... 117

Tabela 19: Resultado da contagem de Giardia lamblia e Cryptosporidium parvum ............. 118

Tabela 20: Resultado obtido nas alterações do DAPI, IP e nova contagem da suspensão de

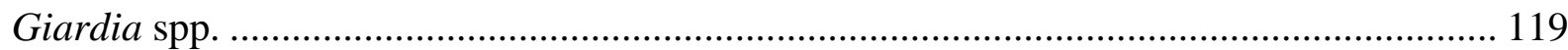

Tabela 21: Resultado do ensaio em triplicata para a suspensão de Giardia lamblia .............. 120

Tabela 22: Resultado do Método 7 IP ................................................................................ 121

Tabela 23: Resultados da leitura da suspensão de Giardia spp. e Cryptosporidium parvum com tempo de 5 min para o IP

Tabela 24: Resultados da leitura da suspensão de Giardia spp. e Cryptosporidium parvum com tempo de 10 min para o IP 
Tabela 25: Resultados da leitura da suspensão de Giardia spp. e Cryptosporidium parvum com tempo de 15 min para o IP

Tabela 26: Resultado da comparação dos resultados obtidos a partir do uso do azul de tripano e do iodeto de propídio.

Tabela 27: Resultado da contagem em triplicata das suspensões de Giardia spp. (5 $\mu \mathrm{L})$ e Cryptosporidium parvum $(50 \mu \mathrm{L})$ para posterior inóculo.

Tabela 28: Resultado do método de concentração de FCCa sem IMS utilizando as suspensões de Giardia spp. e Cryptosporidium parvum.

Tabela 29: Resultado do ensaio de qualidade analítica do protocolo de FCCa sem IMS com o kit Easyseed ${ }^{\circledR}$.

Tabela 30: Resultado do ensaio de qualidade analítica do protocolo de FCCa com IMS com o kit Easyseed ${ }^{\circledR}$.

Tabela 31: Comparação dos métodos avaliados de acordo com os critérios de qualidade para precisão e recuperação contínua (USEPA, 2012)

Tabela 32: Condições sobre os testes de hipóteses adotados a fim de comparar as recuperações dos métodos utilizados (FCCa sem e com IMS).

Tabela 33: Dados utilizados para realização do teste de hipótese.

Tabela 34: Orçamento dos materiais utilizados para uma única amostra (1 de abril de 2016).

Tabela 35: Custo médio do ensaio de controle de qualidade analítica do método de FCCa sem IMS, FCCa com IMS utilizando 2 e 3 dissociações, com dados atualizados utilizando o índice IGP-M (FGV) (1 de abril de 2016). 142

Tabela 36: Determinação do valor e concentração do inóculo a ser utilizado para os 3 L de água filtrada para o ensaio de ozonização para as suspensões de Giardia spp. e Cryptosporidium parvum para a primeira etapa. 144

Tabela 37: Dados obtidos a partir de ensaios de viabilidade do inóculo da suspensão de Giardia spp. e Cryptosporidium parvum para a primeira etapa. 144

Tabela 38: Caracterização da água filtrada antes da desinfecção e após a ozonização dos 3 ensaios com $5 \mathrm{mgO}_{3} \mathrm{~L}^{-1}$ e tempo de contato de 1 min e sem IMS 145

Tabela 39: Concentrações de ozônio aplicado, ozônio do off-gas, ozônio residual dissolvido, ozônio consumido e eficiências na transferência de massa de ozônio para as dosagens de 5 $\mathrm{mgO}_{3} \mathrm{~L}^{-1}$ e tempo de contato de 1 min sem IMS. 146

Tabela 40: Inativação em $\log _{10}$ de Giardia spp. e Cryptosporidium parvum em relação à dosagem de $5 \mathrm{mgO}_{3} \mathrm{~L}^{-1}$, tempo de contato de 1 min e concentração de ozônio consumido. .146 
Tabela 41: Dados de recuperação dos métodos empregados de Giardia spp. e Cryptosporidium parvum para a primeira parte da etapa 1, com dosagem de $5 \mathrm{mgO}_{3} \mathrm{~L}^{-1}$, tempo de contato de 1 min e sem IMS.

Tabela 42: Porcentagem dos organismos viáveis (não corados) e inviáveis (corados) referentes à primeira parte da etapa 1 . 148

Tabela 43: Caracterização da água filtrada antes da desinfecção e após a ozonização dos 3 ensaios com $5 \mathrm{mgO}_{3} \mathrm{~L}^{-1}$ e tempo de contato de 5 min e sem IMS.

Tabela 44: Concentrações de ozônio aplicado, ozônio do off-gas, ozônio residual dissolvido, ozônio consumido e eficiências na transferência de massa de ozônio para as dosagens de 5 $\mathrm{mgO}_{3} \mathrm{~L}^{-1}$ e tempo de contato de 5 min sem IMS.

Tabela 45: Inativação em $\log _{10}$ de Giardia spp. e Cryptosporidium parvum em relação à dosagem de $5 \mathrm{mgO}_{3} \mathrm{~L}^{-1}$, tempo de contato de 5 min e concentração de ozônio consumido. . 150 Tabela 46: Dados de recuperação dos métodos empregados de Giardia spp. e Cryptosporidium parvum para a segunda parte da etapa 1 , com dosagem de $5 \mathrm{mgO}_{3} \mathrm{~L}^{-1}$, tempo de contato de 5 min e sem IMS.

Tabela 47: Porcentagem dos organismos não corados e corados referentes à segunda parte da etapa 1.

Tabela 48: Determinação do valor e concentração do inóculo a ser utilizado para os $3 \mathrm{~L}$ de água filtrada para o ensaio de ozonização para as suspensões de Giardia spp. e Cryptosporidium parvum para a segunda etapa.

Tabela 49: Dados obtidos a partir de ensaios de viabilidade do inóculo da suspensão de Giardia spp. e Cryptosporidium parvum para a segunda etapa.

Tabela 50: Caracterização da água filtrada antes da desinfecção e após a ozonização dos 3 ensaios com $5 \mathrm{mgO}_{3} \mathrm{~L}^{-1}$ e tempo de contato de $1 \mathrm{~min}$ e com IMS.

Tabela 51: Concentrações de ozônio aplicado, ozônio do off-gas, ozônio residual dissolvido, ozônio consumido e eficiências na transferência de massa de ozônio para as dosagens de 5 $\mathrm{mgO}_{3} \mathrm{~L}^{-1}$ e tempo de contato de 1 min com IMS.

Tabela 52: Inativação em $\log _{10}$ de Giardia spp. e Cryptosporidium parvum em relação à dosagem de $5 \mathrm{mgO}_{3} \mathrm{~L}^{-1}$, tempo de contato de 1 min e concentração de ozônio consumido. . 155 Tabela 53: Dados de recuperação dos métodos empregados de Giardia spp. e Cryptosporidium parvum para a primeira parte da etapa 2, com dosagem de $5 \mathrm{mgO}_{3} \mathrm{~L}^{-1}$, tempo de contato de 1 min e com IMS. 156

Tabela 54: Porcentagem dos organismos não corados e corados referentes à primeira parte da etapa 2. 
Tabela 55: Caracterização da água filtrada antes da desinfecção e após a ozonização dos 3 ensaios com $5 \mathrm{mgO}_{3} \mathrm{~L}^{-1}$ e tempo de contato de 5 min e com IMS.

Tabela 56: Concentrações de ozônio aplicado, ozônio do off-gas, ozônio residual dissolvido, ozônio consumido e eficiências na transferência de massa de ozônio para as dosagens de 5 $\mathrm{mgO}_{3} \mathrm{~L}^{-1}$ e tempo de contato de 5 min com IMS 158

Tabela 57: Inativação em $\log _{10}$ de Giardia spp. e Cryptosporidium parvum em relação à dosagem de $5 \mathrm{mgO}_{3} \mathrm{~L}^{-1}$, tempo de contato de 5 min e concentração de ozônio consumido. .159 Tabela 58: Dados de recuperação dos métodos empregados de Giardia spp. e Cryptosporidium parvum para a segunda parte da etapa 2, com dosagem de $5 \mathrm{mgO}_{3} \mathrm{~L}^{-1}$, tempo de contato de 5 min e com IMS.

Tabela 59: Porcentagem dos organismos não corados e corados referentes à segunda parte da etapa 2 161

Tabela 60: Considerações sobre os testes de hipóteses adotados a fim de comparar os tempos de contato de 1 e 5 min, nas Etapas 1 e 2 . 164

Tabela 61: Dados utilizados para aplicação do teste-t e valores obtidos 165

Tabela 62: Considerações sobre os testes de hipóteses adotados a fim de comparar os métodos de FCCa sem e com IMS, para os tempos de 1 e 5 min, nas Etapas 1 e 2. 166

Tabela 63: Dados utilizados para aplicação do teste-t e valores obtidos 166 Tabela 64: Considerações sobre os testes de hipóteses utilizados para comparação entre as recuperações com duas e três dissociações ácidas

Tabela 65: Resultados do teste de hipóteses comparando as recuperações com duas e três dissociações ácidas.

Tabela 66: Valor médio de uma aplicação do método de FCCa com e sem IMS, utilizando 2 ou 3 dissociações ácidas, com dados atualizados para abril de 2016, pelo índice IGP-M (FGV). 


\section{LISTA DE FIGURAS}

Figura 1: Diagrama de seleção da flotação baseado na qualidade da água bruta (condições médias) (VALADE et al., 2009)

Figura 2: Diagrama de seleção da flotação baseado na qualidade da água bruta (condições máximas) (VALADE et al., 2009). 35

Figura 3: Bombona de $200 \mathrm{~L}$ acoplada ao misturador elétrico. 49

Figura 4: Equipamento de Floteste utilizado na pesquisa. 51

Figura 5: Filtros de laboratório de areia - FLA. 52

Figura 6: Produtos pertencentes ao Kit Merifluor ${ }^{\circledR}$. Da esquerda para a direita: Solução tampão concentrada 20 x; Reagente de detecção; Contra corante e meio de montagem. 54 Figura 7: Foto do kit Dynabeads ${ }^{\circledR}$ Life Technologies $^{\mathrm{TM}}$. Produtos pertencentes ao kit. Da esquerda para a direita: Solução tampão SL-A 10X; Solução tampão SL-B 10X; Dynabeads ${ }^{\circledR}$ anti-Giardia e Dynabeads ${ }^{\circledR}$ anti-Cryptosporidium.

Figura 8: Produção de ozônio $\left(\mathrm{gO}_{3} \cdot \mathrm{h}^{-1}\right)$ obtida através da regulação da vazão de ozônio $\left(\mathrm{L} \cdot \mathrm{min}^{-1}\right)$ e tensão adotada (\%) (VIEIRA, 2016). 80

Figura 9: Unidade piloto de ozonização construída no LATAR. 81

Figura 10: Detalhes da coluna de ozonização. a) coluna em acrílico; b) topo da coluna com o registro esfera; c) vista superior da coluna (alimentação) e d) base da coluna e válvula de descarte da amostra. 82

Figura 11: Frasco lavador de gás. 83

Figura 12: Gerador de ozônio. 84

Figura 13: Rotâmetro utilizado para regular a vazão de oxigênio. 84 Figura 14: Diagrama de coagulação para turbidez nas seguintes condições: dosagem de PAC entre 25 e $45 \mathrm{mg} \cdot \mathrm{L}^{-1 \mathrm{c}}, \mathrm{G}_{\mathrm{mr}}=700 \mathrm{~s}^{-1}, \mathrm{~T}_{\mathrm{mr}}=15 \mathrm{~s}, \mathrm{G}_{\mathrm{ml}}=50 \mathrm{~s}^{-1}, \mathrm{~T}_{\mathrm{ml}}: 4 \mathrm{~min}$, tempo de flotação = 5 min, taxa de recirculação $=5 \%$ e pressão de saturação $=5$ bar. 93 Figura 15: Diagrama de coagulação para cor aparente nas seguintes condições: dosagem de PAC entre 25 e $45 \mathrm{mg} \cdot \mathrm{L}^{-1}, \mathrm{G}_{\mathrm{mr}}=700 \mathrm{~s}^{-1}, \mathrm{~T}_{\mathrm{mr}}=15 \mathrm{~s}, \mathrm{G}_{\mathrm{ml}}=50 \mathrm{~s}^{-1}, \mathrm{~T}_{\mathrm{ml}}: 4 \mathrm{~min}$, tempo de flotação $=5 \min$, taxa de recirculação $=5 \%$ e pressão de saturação $=5$ bar.

Figura 16: Otimização do gradiente de mistura rápida conforme valores de turbidez remanescente. Ensaios realizados nas seguintes condições: Dosagem de PAC: $25 \mathrm{mg} . \mathrm{L}^{-1}, \mathrm{G}_{\mathrm{mr}}$ entre 600 e $1000 \mathrm{~s}^{-1}, \mathrm{~T}_{\mathrm{mr}}=15 \mathrm{~s}, \mathrm{G}_{\mathrm{ml}}=50 \mathrm{~s}^{-1}, \mathrm{~T}_{\mathrm{ml}}=4 \mathrm{~min}, \mathrm{~T}_{\text {flot }}=5 \mathrm{~min}$, taxa de recirculação $=$ $5 \%$, pressão de saturação $=5$ bar. Ensaios em triplicata. 
Figura 17: Otimização do gradiente de mistura rápida conforme valores de cor aparente remanescente. Ensaios realizados nas seguintes condições: Dosagem de PAC: 25 mg.L $\mathrm{L}^{-1}, \mathrm{G}_{\mathrm{mr}}$ entre 600 e $1000 \mathrm{~s}^{-1}, \mathrm{~T}_{\mathrm{mr}}=15 \mathrm{~s}, \mathrm{G}_{\mathrm{ml}}=50 \mathrm{~s}^{-1}, \mathrm{~T}_{\mathrm{ml}}=4 \mathrm{~min}, \mathrm{~T}_{\text {flot }}=5 \mathrm{~min}$, taxa de recirculação $=$ $5 \%$, pressão de saturação $=5$ bar. Ensaios em triplicata.

Figura 18: Otimização do tempo de mistura rápida conforme valores de turbidez remanescente. Ensaios realizados nas seguintes condições: Dosagem de PAC: 25 mg.L $\mathrm{L}^{-1}, \mathrm{G}_{\mathrm{mr}}$ $=700 \mathrm{~s}^{-1}, \mathrm{~T}_{\mathrm{mr}}$ entre 5 e $20 \mathrm{~s}, \mathrm{G}_{\mathrm{ml}}=50 \mathrm{~s}^{-1}, \mathrm{~T}_{\mathrm{ml}}=4 \mathrm{~min}, \mathrm{~T}_{\mathrm{flot}}=5 \mathrm{~min}$, taxa de recirculação $=$ $5 \%$, pressão de saturação $=5$ bar. Ensaios em triplicata.

Figura 19: Otimização do tempo de mistura rápida conforme valores de cor aparente remanescente. Ensaios realizados nas seguintes condições: Dosagem de PAC: 25 mg.L ${ }^{-1}, \mathrm{G}_{\mathrm{mr}}$ $=700 \mathrm{~s}^{-1}, \mathrm{~T}_{\mathrm{mr}}$ entre 5 e $20 \mathrm{~s}, \mathrm{G}_{\mathrm{ml}}=50 \mathrm{~s}^{-1}, \mathrm{~T}_{\mathrm{ml}}=4 \mathrm{~min}, \mathrm{~T}_{\text {flot }}=5 \mathrm{~min}$, taxa de recirculação $=$ $5 \%$, pressão de saturação $=5$ bar. Ensaios em triplicata. 98

Figura 20: Otimização do gradiente de mistura lenta conforme valores de turbidez remanescente. Ensaios realizados nas seguintes condições: Dosagem de PAC: 25 mg.L $\mathrm{L}^{-1}, \mathrm{G}_{\mathrm{mr}}$ $=700 \mathrm{~s}^{-1}, \mathrm{~T}_{\mathrm{mr}}=10 \mathrm{~s}, \mathrm{G}_{\mathrm{ml}}$ entre 30 e $80 \mathrm{~s}^{-1}, \mathrm{~T}_{\mathrm{ml}}=4 \mathrm{~min}, \mathrm{~T}_{\text {flot }}=5 \mathrm{~min}$, taxa de recirculação $=$ $5 \%$, pressão de saturação $=5$ bar. Ensaios em triplicata.

Figura 21: Otimização do gradiente de mistura lenta conforme valores de cor aparente remanescente. Ensaios realizados nas seguintes condições: Dosagem de PAC: 25 mg.L ${ }^{-1}, \mathrm{G}_{\mathrm{mr}}$ $=700 \mathrm{~s}^{-1}, \mathrm{~T}_{\mathrm{mr}}=10 \mathrm{~s}, \mathrm{G}_{\mathrm{ml}}$ entre 30 e $80 \mathrm{~s}^{-1}, \mathrm{~T}_{\mathrm{ml}}=4 \mathrm{~min}, \mathrm{~T}_{\text {flot }}=5 \mathrm{~min}$, taxa de recirculação $=$ $5 \%$, pressão de saturação $=5$ bar. Ensaios em triplicata.

Figura 22: Otimização do tempo de mistura lenta conforme valores de turbidez remanescente. Ensaios realizados nas seguintes condições: Dosagem de PAC: $25 \mathrm{mg} \cdot \mathrm{L}^{-1}, \mathrm{G}_{\mathrm{mr}}=700 \mathrm{~s}^{-1}, \mathrm{~T}_{\mathrm{mr}}=$ $10 \mathrm{~s}, \mathrm{G}_{\mathrm{ml}}=60 \mathrm{~s}^{-1}, \mathrm{~T}_{\mathrm{ml}}$ entre 1 e $8 \mathrm{~min}, \mathrm{~T}_{\mathrm{flot}}=5 \mathrm{~min}$, taxa de recirculação $=5 \%$, pressão de saturação $=5$ bar. Ensaios em triplicata.

Figura 23: Otimização do tempo de mistura lenta conforme valores de cor aparente remanescente. Ensaios realizados nas seguintes condições: Dosagem de PAC: 25 mg.L ${ }^{-1}, \mathrm{G}_{\mathrm{mr}}$ $=700 \mathrm{~s}^{-1}, \mathrm{~T}_{\mathrm{mr}}=10 \mathrm{~s}, \mathrm{G}_{\mathrm{ml}}=60 \mathrm{~s}^{-1}, \mathrm{~T}_{\mathrm{ml}}$ entre 1 e $8 \mathrm{~min}, \mathrm{~T}_{\text {flot }}=5 \mathrm{~min}$, taxa de recirculação $=$ $5 \%$, pressão de saturação $=5$ bar. Ensaios em triplicata.

Figura 24: Otimização do tempo de flotação conforme valores de turbidez remanescente. Ensaios realizados nas seguintes condições: Dosagem de PAC: $25 \mathrm{mg} \cdot \mathrm{L}^{-1}, \mathrm{G}_{\mathrm{mr}}=700 \mathrm{~s}^{-1}, \mathrm{~T}_{\mathrm{mr}}=$ $10 \mathrm{~s}, \mathrm{G}_{\mathrm{ml}}=60 \mathrm{~s}^{-1}, \mathrm{~T}_{\mathrm{ml}}=4 \mathrm{~min}, \mathrm{~T}_{\text {flot }}$ entre 2 e $10 \mathrm{~min}$, taxa de recirculação $=5 \%$, pressão de saturação $=5$ bar. Ensaios em triplicata.

Figura 25: Otimização do tempo de flotação conforme valores de cor aparente remanescente. Ensaios realizados nas seguintes condições: Dosagem de PAC: $25 \mathrm{mg} \cdot \mathrm{L}^{-1}, \mathrm{G}_{\mathrm{mr}}=700 \mathrm{~s}^{-1}, \mathrm{~T}_{\mathrm{mr}}=$ 
$10 \mathrm{~s}, \mathrm{G}_{\mathrm{ml}}=60 \mathrm{~s}^{-1}, \mathrm{~T}_{\mathrm{ml}}=4 \mathrm{~min}, \mathrm{~T}_{\text {flot }}$ entre 2 e $10 \mathrm{~min}$, taxa de recirculação $=5 \%$, pressão de saturação $=5$ bar. Ensaios em triplicata.

Figura 26: Otimização do tempo de flotação conforme valores de turbidez remanescente. Ensaios realizados nas seguintes condições: Dosagem de PAC: $25 \mathrm{mg} \cdot \mathrm{L}^{-1}, \mathrm{G}_{\mathrm{mr}}=700 \mathrm{~s}^{-1}, \mathrm{~T}_{\mathrm{mr}}=$ $10 \mathrm{~s}, \mathrm{G}_{\mathrm{ml}}=60 \mathrm{~s}^{-1}, \mathrm{~T}_{\mathrm{ml}}=4 \mathrm{~min}, \mathrm{~T}_{\text {flot }}=10 \mathrm{~min}$, taxa de recirculação entre 5 e $20 \%$, pressão de saturação $=5$ bar. Ensaios em triplicata. 103

Figura 27: Otimização do tempo de flotação conforme valores de cor aparente remanescente. Ensaios realizados nas seguintes condições: Dosagem de PAC: $25 \mathrm{mg} \cdot \mathrm{L}^{-1}, \mathrm{G}_{\mathrm{mr}}=700 \mathrm{~s}^{-1}, \mathrm{~T}_{\mathrm{mr}}=$ $10 \mathrm{~s}, \mathrm{G}_{\mathrm{ml}}=60 \mathrm{~s}^{-1}, \mathrm{~T}_{\mathrm{ml}}=4 \mathrm{~min}, \mathrm{~T}_{\mathrm{flot}}=10 \mathrm{~min}$, taxa de recirculação entre 5 e $20 \%$, pressão de saturação $=5$ bar. Ensaios em triplicata..................................................................... 104

Figura 28: Curva de flotação para turbidez. Ensaio em triplicata........................................ 105

Figura 29: Curva de flotação para cor aparente. Ensaio em triplicata. .................................. 106 Figura 30: Imagem da lâmina de Giardia spp. com o azul de tripano. 1, 2 e 3: Cistos de Giardia que não penetraram o corante e 4: Cisto de Giardia que penetrou o corante, (aumento de $400 \mathrm{x})$.

Figura 31: Imagem da lâmina de Cryptosporidium parvum com o azul de tripano, em que o oocisto não penetrou o corante (cisto viável) (Aumento de 400 x). 113

Figura 32: Resultado do Método 1 IP onde houve formação de cristais na lâmina. 115

Figura 33: Aglomerado de cistos de Giardia lamblia (Aumento de 400 x). 116

Figura 34: Formação de aglomerados de cistos de Giardia lamblia observados na lente UV (aumento de $400 \mathrm{x}$ ).

Figura 35: Aglomerado de cistos de Giardia lamblia observados em filtro DAPI com a Solução Comercial Fluoroshield ${ }^{\mathrm{TM}}$ with DAPI (Aumento de 400 x). 118

Figura 36: Tentativa de análise de viabilidade observado em filtro WG para visualizar o corante IP utilizando a suspensão de Giardia lamblia com formação de aglomerados (Aumento de $400 \mathrm{x}$ ). 119

Figura 37: Do lado esquerdo são visualizados 2 cistos de Giardia spp. na lente UV. Do lado direito, os cistos foram observados em lente WG para visualizar o IP, a flecha de cima aponta o cisto não corado e a de baixo, o corado (aumento de $400 \mathrm{x}$ ).

Figura 38: Na parte superior, visualizaram-se oocisto na lente UV. Na parte inferior, do lado esquerdo, observa-se o oocisto sem a penetração do corante e do lado direito, com a inclusão do corante (aumento de $400 \mathrm{x}$ ).

Figura 39: Visualização de um cisto de Giardia spp., à esquerda em lente UV e a direita em DAPI com 3 núcleos (Aumento de 400 x). 
Figura 40: Visualização de um oocisto de Cryptosporidium parvum, à esquerda em lente UV e a direita em DAPI com 2 núcleos (Aumento de 400 x).

Figura 41: Porcentagem de cistos de Giardia spp. não corados (viáveis) para os tempos de exposição de 5, 10 e 15 min.

Figura 42: Porcentagem de oocistos de Cryptosporidium parvum não corados (viáveis) para os tempos de exposição de 5, 10 e 15 min.

Figura 43: Imagem dos (oo) cistos durante ensaio do tempo de contato de 15 min de IP. À esquerda: 4 cistos de Giardia coradas e à direita, 1 oocisto de Cryptosporidium corado.

Figura 44: Sujidades observadas na lâmina do ensaio de controle de qualidade do método FCCa sem IMS.

Figura 45: Imagem da visualização do poço do ensaio de controle de qualidade do método FCCa utilizando IMS. 138

Figura 46: Cistos de Giardia spp. com deformação após a desinfecção com o ozônio (Aumento de $400 \mathrm{x}$ ).

Figura 47: Porcentagem de recuperação de Giardia spp. para cada dissociação para o tempo de $1 \mathrm{~min}$.

Figura 48: Porcentagem de recuperação de Cryptosporidium parvum para cada dissociação para o tempo de $1 \mathrm{~min}$.

Figura 49: Porcentagem de recuperação de Giardia spp. para cada dissociação para o tempo de 5 min. 171

Figura 50: Porcentagem de recuperação de Cryptosporidium parvum para cada dissociação para o tempo de $5 \mathrm{~min}$.

Figura 51: Visualização de oocisto de Cryptosporidium parvum em fluorescência à esquerda e visualização em DAPI à direita na primeira dissociação ácida.

Figura 52: Visualização de cisto de Giardia spp. em fluorescência à esquerda e visualização em DAPI à direita na segunda dissociação ácida. 174

Figura 53: À esquerda, cisto de Giardia spp. com deformidade na membrana visualizado na terceira dissociação ácida e à direita, mesmo cisto visualizado em DAPI (Aumento de 400 x). 


\section{LISTA DE ABREVIATURAS}

APHA - Standard Methods for the Examination of Water and Wastewate

AT - Azul de tripano

COT - Carbono orgânico total

CV - Coeficiente de variação (desvio padrão relativo)

DAPI - 4',6-diamino-2fenil-indol

DIC - Contraste interferencial diferencial

EESC - Escola de Engenharia de São Carlos

ETA - Estação de Tratamento de Água

FAD - Flotação por Ar Dissolvido

FITC - Isotiocianato de fluoresceína

FCCa - Floculação em carbonato de cálcio

FLA - Filtro de Laboratório de Areia

FM - Fator de multiplicação

HBSS - Hanks' Balanced Salt Solution

HIV - Vírus da Imunodeficiência Humana

IMS - Separação imunomagenética

IP - Iodeto de propídio

LATAR - Laboratório de Tratamento Avançado e Reúso de Água

MPC-1 - Concentrador de partículas magnéticas 1

MPC-S - Concentrador de partículas magnéticas 2

OMS - Organização Mundial da Saúde

PAC - Cloreto de polialumínio

PBS - Solução salina de fosfato

PCR - Reação em cadeia de Polimerase

SHS - Departamento de Hidráulica e Saneamento

TLP - Tubo de lado plano

THM - Trihalometanos

UNICAMP - Universidade Estadual de Campinas

USEPA - Agência de proteção ambiental dos Estados Unidos

USP - Universidade de São Paulo 


\section{LISTA DE SÍMBOLOS}

$\mathrm{CaCl}_{2}$ - Cloreto de cálcio

$\mathrm{CaCO}_{3}-$ Carbonato de cálcio

$\mathrm{G}_{\mathrm{ml}}$ - Gradiente de velocidade de mistura lenta

$\mathrm{G}_{\mathrm{mr}}$ - Gradiente de velocidade de mistura rápida

$\log _{10}$ - Logaritmo de base 10

$\mathrm{NaHCO}_{3}-$ Bicarbonato de sódio

$\mathrm{NaOH}$ - Hidróxido de sódio

pH - Potencial hidrogeniônico

$\mathrm{P}_{\text {sat }}$ - Pressão de saturação

Pt-Co - Unidade de cor

$\mathrm{pZ}$ - Potencial zeta

rpm - Rotação por minuto

$\mathrm{T}_{\text {flot }}-$ Tempo de flotação

$\mathrm{T}_{\mathrm{ml}}-$ Tempo de mistura lenta

$\mathrm{T}_{\mathrm{mr}}-$ Tempo de mistura rápida

$\mathrm{T}_{\text {rec }}-$ Taxa de recirculação

uT - Unidade de turbidez (unidade nefolométrica de turbidez)

${ }^{\circ} \mathrm{C}$ - Graus celsius 


\section{SUMÁRIO}

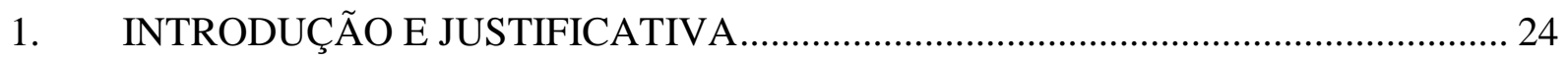

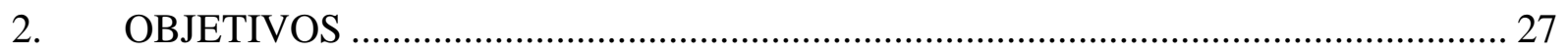

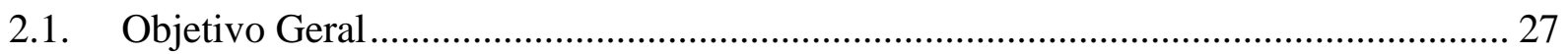

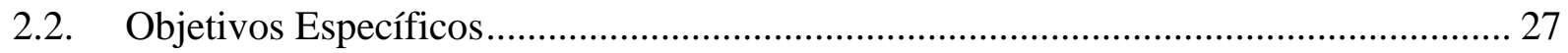

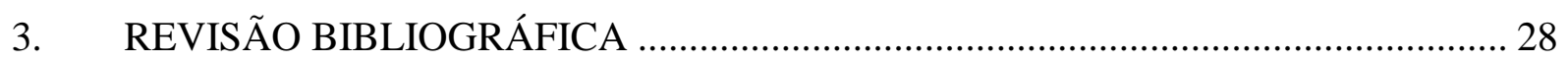

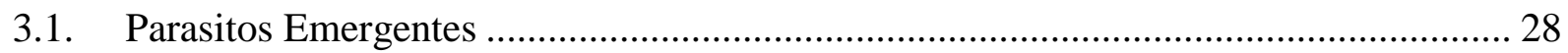

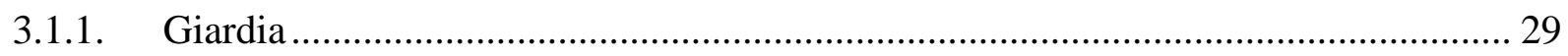

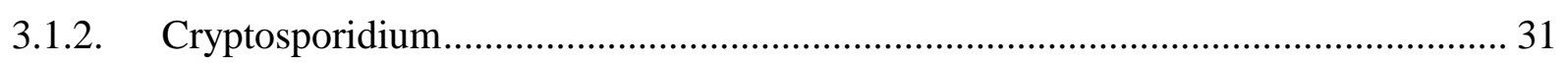

3.2. Remoção de Giardia e Cryptosporidium no Tratamento de Água .............................. 33

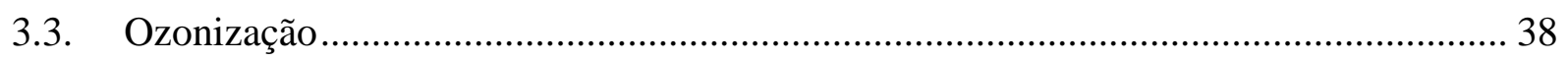

3.4. Controle da Qualidade Analítica dos Métodos de Avaliação de Protozoários em

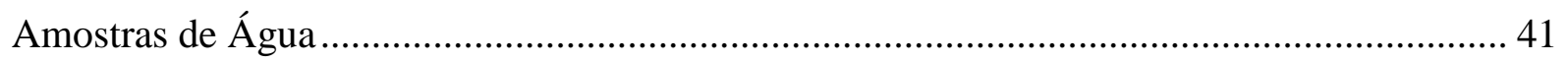

3.5. Métodos de Avaliação de Giardia e Cryptosporidium em Amostras de Água ............ 42

3.5.1. Amostragem e Concentração............................................................................ 42

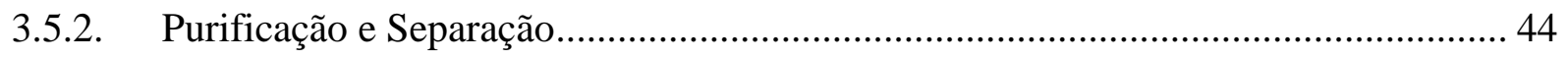

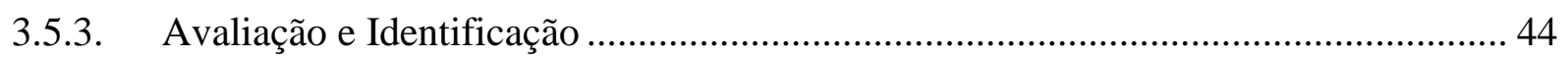

3.6. Métodos de Avaliação de Viabilidade e Infectividade de Protozoários ....................... 44

3.6.1. Teste de Viabilidade Utilizando o Azul de Tripano ............................................... 45

3.6.2. Teste de Viabilidade Utilizando o Iodeto de Propídio ............................................. 46

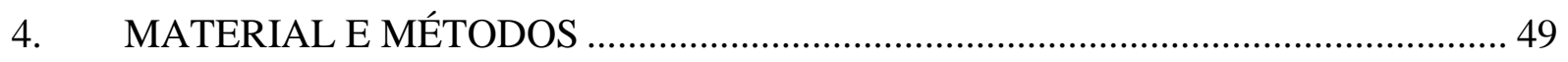

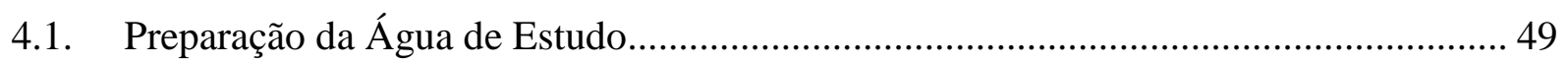

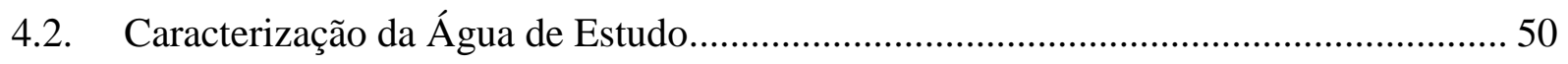

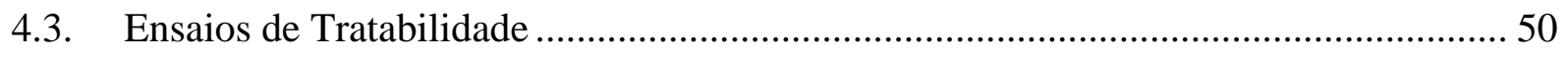

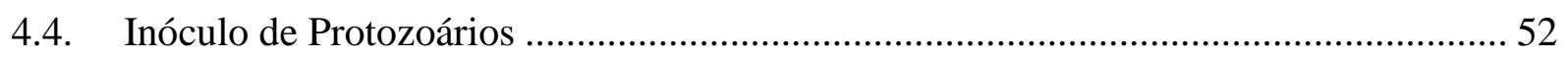

4.5. Homogeneização, Desagregação e Contagem das Cepas e Montagem das Lâminas com o Kit Merifluor ${ }^{\circledR}$ 
4.6. Método De Concentração Dos Protozoários ……......................................................55

4.7. Purificação das Amostras por Separação Imunomagnética (IMS) ................................57

4.8. Procedimento de Preparo das Lâminas com o Kit Merifluor $^{\circledR}$ e Aplicação do DAPI e IP 60

4.9. Identificação de Protozoários Utilizando Microscopia de Imunofluorescência . 61

4.10. Controle da Qualidade Analítica do Método de Concentração (FCCa) em Amostras de Água. 62

4.10.1. Controle da Qualidade Analítica do Método de FCCa Utilizando Suspensões de (oo) cistos.

4.10.2. Controle da Qualidade Analítica do Método de FCCa utilizando o EasySeed ${ }^{\circledR}$....6 63

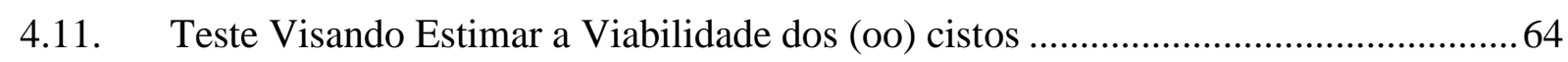

4.11.1. Estimativa da Viabilidade utilizando o Azul de Tripano ......................................6 64

4.11.2. Estimativa da Viabilidade Utilizando o Iodeto de Propídio - IP ..........................6 68

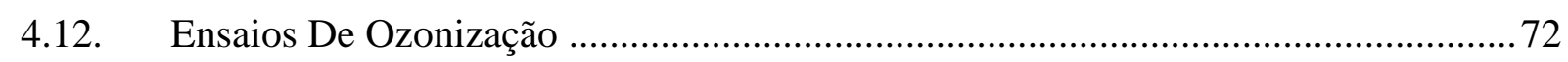

4.12.1. Descrição das Etapas Realizadas Para os Ensaios de Ozonização.......................... 73

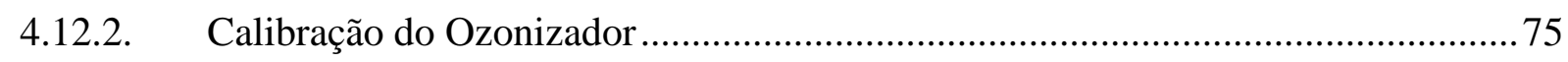

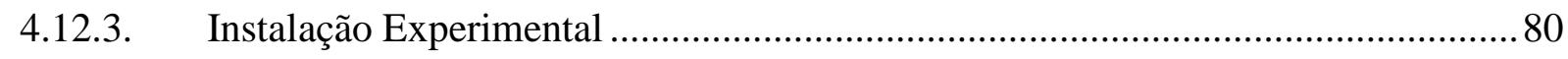

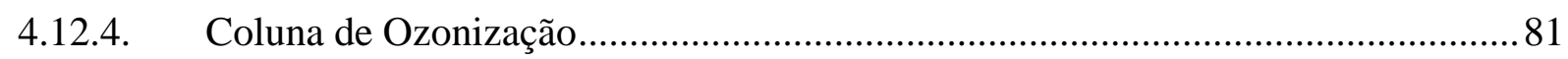

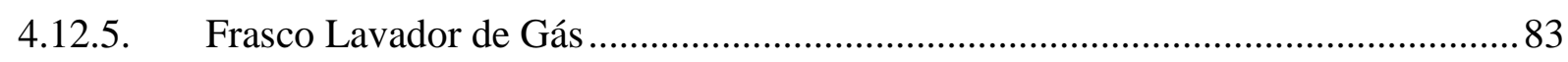

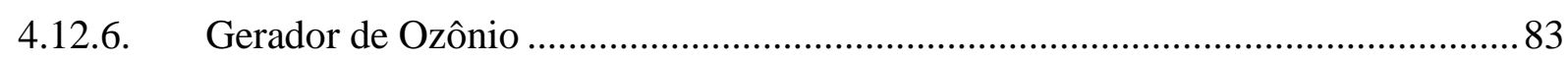

4.12.7. Parâmetros Utilizados para a Realização dos Ensaios de ozonização .................... 84

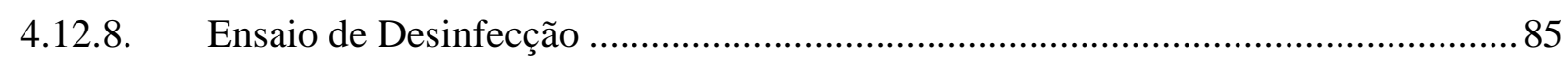

4.12.9. Procedimento Geral para a Realização das Análises da Concentração de Ozônio

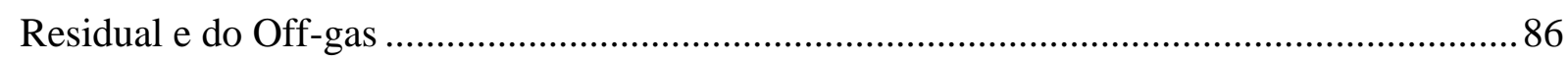

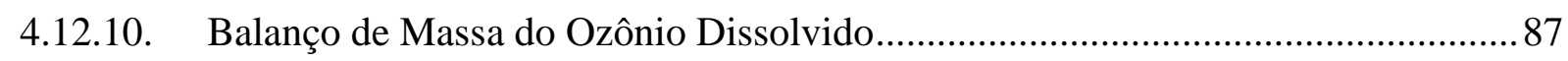

4.13. Manipulação de Amostras Contendo Protozoários e Disposição Final De Resíduos 89

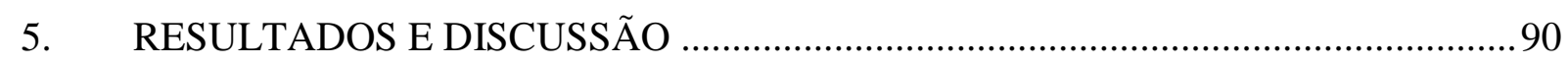

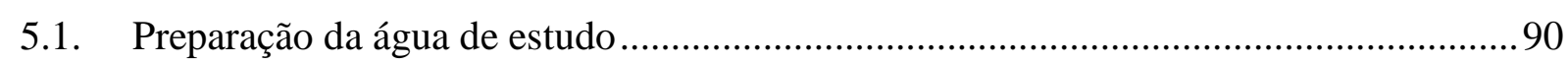




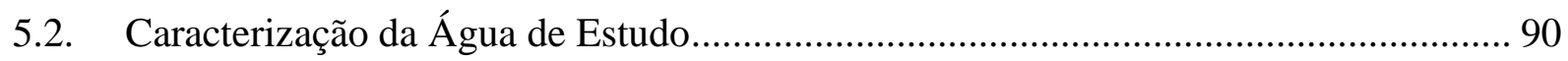

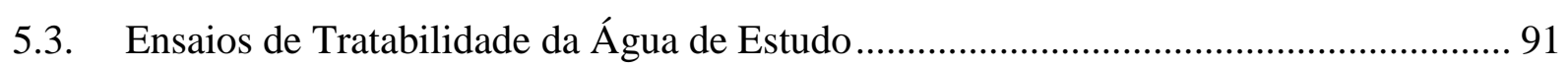

5.3.1. Construção do Diagrama de Coagulação ........................................................... 91

5.4. Otimização dos Parâmetros do Ensaio de Tratabilidade............................................... 96

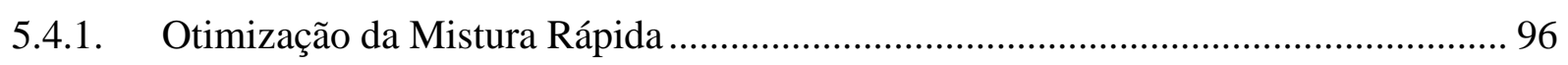

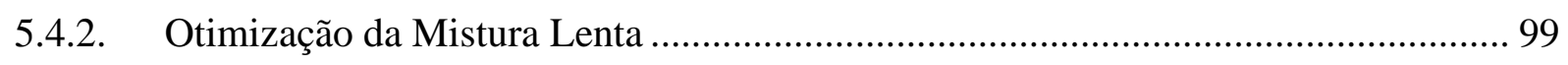

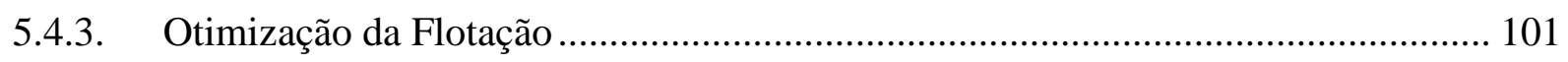

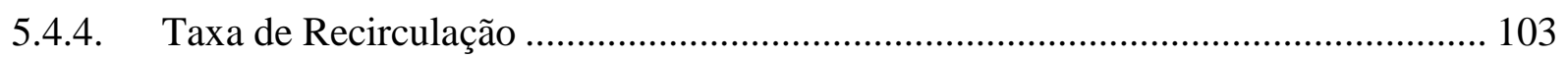

5.4.5. Parâmetros Otimizados.................................................................................. 104

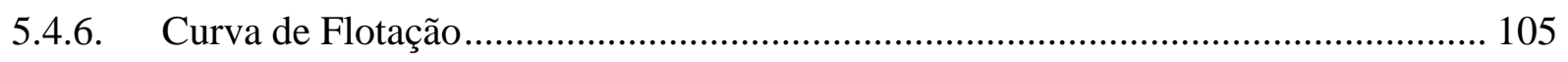

5.4.7. Características da Água Filtrada Após Otimizar os Parâmetros de Tratabilidade .. 106

5.5. Teste Iniciais de Estimativa da Viabilidade da Suspensão ....................................... 107

5.5.1. Avaliação da Estimativa da Viabilidade da Suspensão com Azul de Tripano........ 107

5.5.2. Avaliação da Estimativa da Viabilidade Utilizando IP em conjunto com DAPI e

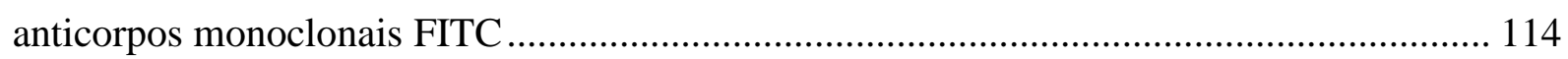

5.5.3. Avaliação comparativa entre os métodos de estimativa da viabilidade utilizando o Azul de Tripano e o IP em conjunto com DAPI e anticorpos monoclonais FITC …............ 127

5.6. Controle da Qualidade Analítica do Método de Concentração (FCCa) em Amostras de Água

5.6.1. Controle da Qualidade Analítica do Método de FCCa sem IMS Utilizando

Suspensões de (oo) cistos

5.6.2. Controle da Qualidade Analítica do Método de FCCa sem e com IMS utilizando o EasySeed ${ }^{\circledR}$

5.6.3. Comparação dos Métodos de FCCa sem e com IMS utilizando o kit EasySeed $^{\circledR}$.. 138

5.7. Ensaio de Ozonização

5.7.1. Etapa 1 - Ensaios de Desinfecção Sem a Etapa de IMS ........................................ 143

5.7.2. Etapa 2 - Ensaios de Desinfecção com o Protocolo de FCCa com IMS .................. 152

5.7.3. Eficiências na transferência de massa, Temperatura e $\mathrm{pH}$.................................... 161 
5.7.4. Inativação, recuperação e perdas dos parasitos.................................................... 163

5.8. Influência da inclusão da terceira dissociação ácida nos ensaios com IMS 169

5.9. Avaliação Econômica dos Ensaios Realizados ......................................................... 175

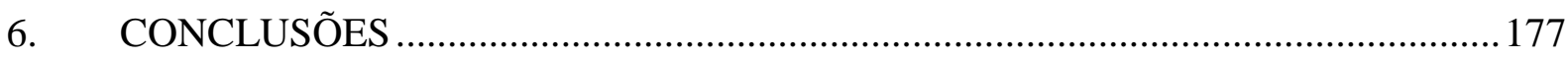

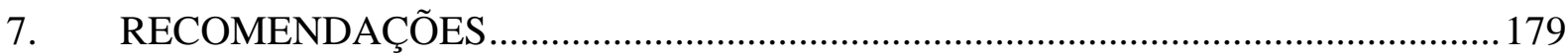

8. REFERÊNCIAS BIBLIOGRÁFICAS ….............................................................. 180 


\section{INTRODUÇÃO E JUSTIFICATIVA}

A água é um recurso natural indispensável na vida dos seres vivos e de grande importância econômica, social e ambiental. Este recurso está disponível na forma superficial e subterrânea e é utilizado pelos seres vivos para usos múltiplos. O acesso à água potável é essencial e faz parte do direito humano básico, sendo um componente de uma política eficiente para a proteção da saúde (WHO, 2011).

O manejo inadequado dos recursos hídricos contribui para sua contaminação, seja por meios físicos, químicos e biológicos, favorecendo a degradação da qualidade ambiental, o que pode influenciar no risco à saúde da população.

Outro tópico importante associado à saúde ambiental é a ocorrência de doenças de veiculação hídrica, mais frequentemente, as doenças parasitárias intestinais, que se apresentam como um sério problema de saúde pública. É notável que tal empecilho à saúde da população esteja diretamente relacionado à precariedade no saneamento básico aliado à consequente degradação ambiental.

Além de todos os benefícios provenientes do acesso à água potável, no quesito de saúde pública, o abastecimento de água de boa qualidade e um sistema de saneamento eficiente resultam, também, na redução dos gastos públicos em questões de internações hospitalares decorrentes de doenças causadas por veiculação hídrica, gastos estes que superam os investimentos em intervenções e melhorias neste setor, que engloba a parte de infraestrutura básica, até mesmo em alternativas simples de tratamento de água para pequenas comunidades e/ou áreas rurais, podendo ser uma parte efetiva na estratégia da redução da pobreza e melhoria da qualidade de vida.

Atualmente, quase 3 bilhões de pessoas no mundo não têm acesso a água de boa qualidade e em quantidade suficiente. Dados da Organização Mundial da Saúde (OMS) estimam que 3,4 milhões de pessoas, principalmente crianças, morrem de enfermidades relacionadas ao consumo de água contaminada, anualmente. As doenças diarreicas, associadas à falta de saneamento, à higiene precária e aos suprimentos inadequados de água, matam aproximadamente 2,2 milhões de pessoas por ano (Franco et al., 2012).

A ocorrência de doenças causadas por veiculação hídrica se dá principalmente pela contaminação dos mananciais. Segundo Bastos, Brandão e Cerqueira (2009) algumas das principais fontes de contaminação dos mananciais de abastecimento têm ocorrido por protozoários, presentes em esgotos sanitários e resíduos de atividades agropecuárias, dentre eles Giardia e Cryptosporidium. 
As doenças de veiculação hídrica, sobretudo aquelas causadas por protozoários intestinais, emergiram como um dos principais problemas de Saúde Pública nos últimos 25 anos (Franco, 2006). De acordo com Heller et al., (2004), embora o conhecimento sobre a presença de protozoários patogênicos, em águas para consumo humano, apresente-se como um problema fundamental relacionado à Saúde Pública em diversos países, o conhecimento sobre os riscos é escasso no Brasil.

Giardia e Cryptosporidium caracterizam-se por serem de difícil remoção nos sistemas de tratamento de água de abastecimento. Cistos de Giardia e oocistos de Cryptosporidium têm dimensões de, aproximadamente, 8 a $18 \mu \mathrm{m}$ de comprimento por 5 a $15 \mu \mathrm{m}$ de largura e 4 a $6 \mu \mathrm{m}$ de diâmetro (USEPA, 2012). Sendo assim, são passíveis de serem removidos por filtração. Porém, apesar de ambos possuírem características semelhantes de sedimentação e filtração, devido ao tamanho, a remoção de oocistos de Cryptosporidium por filtração é algo inferior à de cistos de Giardia (Héller et al., 2004). Isso pode ser explicado, devido à capacidade de compressibilidade dos oocistos, os quais, durante a etapa de filtração, passam a se comportar como uma partícula de 2 a $4 \mu \mathrm{m}$ (FRANCO, 2007).

O desempenho do cloreto de polialumínio - PAC foi analisado na remoção de turbidez e cor aparente, e a sua aplicação está sendo reportada por vários pesquisadores (PAVANELLI, 2001; CORRÊA et al., 2005; JULIO et al., 2010; FERRARI; DE JULIO; DE JULIO, 2011; MACIEL, 2014; GIGLIO, 2015). Este coagulante foi escolhido por não ter necessidade de pré-alcalinização, resultando em grande vantagem do ponto de vista operacional e econômico, e também, pode reduzir a produção do lodo gerado em estações de tratamento de água-ETAs, comparado aos demais coagulantes tradicionais.

As formas de resistência destes protozoários são suscetíveis de sobreviver aos processos de desinfecção com cloro, possuem baixa dose infectante e são capazes de sobreviver aos fatores ambientais adversos. Entretanto, para a diminuição do risco microbiológico das águas de consumo algumas medidas devem ser tomadas, como, a utilização de um desinfetante na inativação dos (oo) cistos, aliado ao funcionamento eficaz dos processos e operações de tratamento de água.

O ozônio é agente oxidante poderoso, atuando como desinfetante alternativo ao cloro, muito eficiente na inativação de bactérias, vírus, protozoários e outros parasitas (SOUZA, 2006; DA SILVA et al., 2011; LAPOLLI et al., 2003). 
Franco et al., (2012) relatam que as metodologias de detecção de Giardia e Cryptosporidium, atualmente empregadas, ainda estão sujeitas a grande variabilidade e baixa reprodutibilidade, além do alto custo quando comparados com as análises de outros parâmetros de qualidade da água.

Devido à problemática atual, a pesquisa avaliou a inativação de Giardia spp. e Cryptosporidium parvum em água filtrada obtida após tratamento convencional com flotação. Essa situação de risco microbiológico pode acontecer, conforme, relato de autores como Le Chevallier, Norton e Lee (1991), Aboytes et al., (2004), Huck et al., (2002).

A presente pesquisa é fundamental devido à carência de estudos brasileiros nesta área e, também, porque a Portaria $n^{\circ} 2914$ (Brasil, 2011) apresenta a necessidade de monitoramento dos protozoários Cryptosporidium spp. e Giardia spp. quando a média geométrica anual de Escherichia coli, encontrada na água bruta superficial, for maior ou igual a 1000 E. coli $/ 100 \mathrm{ml}$. 


\section{OBJETIVOS}

\subsection{Objetivo Geral}

Avaliar a viabilidade de Giardia spp. e Cryptosporidium parvum em água filtrada, após tratamento convencional com flotação, utilizando ozônio.

\subsection{Objetivos Específicos}

- Avaliar o desempenho do cloreto de polialumínio (PAC) na remoção de parâmetros físico-químicos presentes na água de estudo;

- Avaliar o azul de tripano e o iodeto de propídio em conjunto com DAPI e anticorpos monoclonais FITC visando ponderar a viabilidade dos (oo) cistos na perspectiva da engenharia prática;

- Analisar a eficiência do ozônio na inativação de Giardia spp. e Cryptosporidium parvum em amostras de água filtrada; e

- Avaliar a metodologia de floculação em carbonato de cálcio, com e sem separação imunomagnética, na detecção de (oo) cistos de protozoários na água filtrada. 


\section{REVISÃO BIBLIOGRÁFICA}

\subsection{Parasitos Reemergentes}

Em meados do século XIX começou-se a relacionar a água com transmissão de doenças, ficando estabelecido com a descoberta do médico John Snow que provou, através de estudos epidemiológicos, que o surto de cólera ocorrido em Londres havia acontecido pelo consumo de água contaminada. Atualmente, a lista de organismos patogênicos, que podem estar presentes na água de consumo, aumentou consideravelmente, incluindo bactérias, vírus e protozoários.

Os protozoários são organismos unicelulares (portanto microrganismos), eucariotas, quimio-heterotróficos e pertencem ao Reino Protista.

Os microrganismos emergentes têm despertado a atenção e/ou preocupação de médicos, especialistas e/ou epidemiologistas. A emergência desses parasitos não está relacionada ao fato de serem espécies recém-descobertas, mas sim ao fato de que recentemente têm-se registrado, em diferentes países, surtos de doenças em que os mesmos foram identificados como os agentes etiológicos em águas de consumo (BEVILACQUA; AZEVEDO; CERQUEIRA, 2009).

Alguns aspectos relevantes associados ao ciclo de vida dos parasitos Giardia e Cryptosporidium devem ser mencionados, uma vez que contribuem para que a transmissão através da água de consumo seja mais provável. Eles podem-se hospedar tanto em animais como em humanos e, normalmente, eliminam-se grandes quantidades em suas formas infectantes (cistos e oocistos). As doenças causadas por Cryptosporidium e Giardia são facilitadas devido à necessidade de doses infectantes relativamente baixas para causar novos casos de infecção/doença (BEVILACQUA; AZEVEDO; CERQUEIRA, 2009).

Giardíase e criptosporidiose também são infecções comuns de animais domésticos e selvagens, que lançam um grande número de cistos e oocistos no ambiente. (CACCIÒ et al., 2003).

Os protozoários surgiram como um dos principais parasitos associados à veiculação hídrica causando pelo menos 325 surtos, sendo 32\% associados a Giardia duodenalis e 23,7\% ao Cryptosporidium spp. (KARANIS; KOURENT; SMITH, 2007).

A preocupação com outros indicadores de qualidade da água aumentou após o surto ocorrido em Milwaukee, Wisconsin, EUA, o qual atingiu cerca de 400 mil pessoas, causando 
100 óbitos em abril de 1993 (PLUMMER; EDZWALD; KELLEY, 1995). A epidemia gerada pela presença de Cryptosporidium ocorreu devido ao lançamento de despejos de uma estação de tratamento de esgoto no mesmo lago que era utilizado para o abastecimento público (DANIEL, 2001).

Diversos fatores contribuem para a dispersão dos (oo) cistos no ambiente, entre eles está a sobrevivência das formas resistentes à cloração da água, além de apresentar persistência às condições ambientais adversas permanecendo infectantes, por exemplo, por um período de até seis meses, em águas superficiais, à $20^{\circ} \mathrm{C}$ (FAYER, 2004).

De acordo com Heller et al., (2004) as doenças conhecidas como giardíase e cryptosporidíase são, reconhecidamente, zoonoses, o que indica que as principais fontes de contaminação dos mananciais, estão relacionadas aos esgotos sanitários, dejetos e efluentes de atividades agropecuárias. Espera-se, então, que a ocorrência e a concentração desses organismos nas águas superficiais sejam maiores nos países em desenvolvimento, considerando o precário saneamento.

No Brasil, os dados referentes às doenças de veiculação hídrica pelos protozoários Giardia e Cryptosporidium ainda são insuficientes. O monitoramento dos corpos d'água, relacionado à presença dos parasitos supracitados, é mais presente na região Sudeste, com enfoque para os Estados de Minas Gerais e São Paulo. Apesar de nenhum surto de transmissão hídrica estar associado a esses parasitos no Brasil, é possível que esses dados sejam subestimados, visto que a pesquisa desses protozoários não é uma prática de rotina nos laboratórios brasileiros (CANTUSIO NETO et al., 2010).

\subsubsection{Giardia}

Giardia foi descrita pela primeira vez pelo pesquisador Anton van Leeuwenhoek em 1681. Pertencente à ordem Diplomonadida e à família Hexamitidae.

Giardia lamblia é um parasito flagelado mais conhecido de espécies de mamíferos, incluindo humanos, e é considerado como o protozoário responsável e mais comum por causar diarreia em todo o mundo (CACCIÒ; SPRONG, 2011).

Giardia é um protozoário intestinal que infecta uma ampla gama de hospedeiros vertebrados. O gênero é atualmente composto por seis espécies, ou seja, Giardia agilis, Giardia ardeae, Giardia duodenalis, Giardia psittaci, Giardia muris e Giardia microti. 
Giardia duodenalis (sinônimo de Giardia intestinalis e Giardia lamblia) é a única espécie do gênero Giardia encontrada em humanos e é o protozoário parasita de humanos mais comum em países desenvolvidos e em desenvolvimento (FENG; XIAO, 2011; CACCIÒ; SPRONG, 2011).

Membros do gênero Giardia infectam o intestino delgado em humanos e outros mamíferos, causando giardíase, que apresentam sintomas tais como, diarreia, dores de estômago, náuseas e fadiga (HSU; YEH, 2003).

A infecção ocorre exclusivamente pela ingestão de cistos, através de água e/ou alimentos, pela ingestão acidental de água recreacional, pelo contato direto em situações de higiene precária e a transmissão também pode ocorrer pelo contato interpessoal ou atividade sexual (CACCIÒ; SPRONG, 2011; SANTOS, 2007).

O ciclo de vida da Giardia é direto e envolve dois estágios principais, a fase de trofozoíto, que é a fase de replicação, e a forma de cisto, que é a fase infecciosa (RYAN; CACCIÒ, 2013). Os cistos de Giardia possuem morfologia ovalada, e têm dimensões de, aproximadamente, 8 a $18 \mu \mathrm{m}$ de comprimento por 5 a $15 \mu \mathrm{m}$ de largura (USEPA, 2012).

Após a ingestão oral, a parede do cisto se rompe e o trofozoíto é liberado na parte superior do intestino delgado. Para a colonização do intestino delgado, é imprescindível que aconteça a adesão das células epiteliais, através do disco adesivo ventral do trofozoíto. Os trofozoítos se multiplicam por divisão binária no lúmen do intestino delgado. Finalmente, a exposição aos sais biliares conduz o encistamento dos trofozoítos, e os cistos formados são imediatamente infecciosos, e então são eliminados nas fezes, permitindo a conclusão do ciclo de vida em até $72 \mathrm{~h}$ depois da infecção (GUERDEN; OLSON, 2011).

Um indivíduo infectado pode eliminar até $10^{5}$ cistos $/ g$ de fezes e a dose infectante da Giardia é de 1-10 cistos. Situações comprovadas de contaminação, como, através da transmissão fecal-oral entre pessoas, por exemplo, no ambiente domiciliar ou nas escolas esteja consolidada, cada vez mais se confirma a importância epidemiológica da transmissão via abastecimento e consumo de água, e também pelo consumo de hortaliças. Outro fator importante são os esgotos sanitários, que são comprovadamente fontes de contaminação relevantes de mananciais de abastecimento (BASTOS; BEVILACQUA; KELLER, 2003).

Para complementar o problema, as doses de cloro usualmente aplicadas no tratamento da água não são suficientes para efetiva e completa inativação dos cistos, concedendo o papel de sua remoção, em grande parte, à filtração (BASTOS; BEVILACQUA; KELLER, 2003).

Os cistos de Giardia quando comparados com oocistos de Cryptosporidium sobrevivem por menos tempo na água e são menos resistentes aos processos de desinfecção 
comumente utilizados. Os cistos de Giardia conseguem sobreviver na água por até 2 meses a temperaturas tão baixas como $8^{\circ} \mathrm{C}$ (CACCIÒ et al., 2003) e em função do seu tamanho, são passíveis de serem removidos em uma estação de tratamento de água, ao passarem pela etapa de filtração (CACCIÓ et al., 2005).

\subsubsection{Cryptosporidium}

O gênero Cryptosporidium foi descrito pela primeira vez pelo pesquisador Ernest E. Tyzzer na primeira década do século XX, no ano de 1907 e a primeira infecção humana foi registrada em 1976 (LEITCH; HE, 2011).

O papel do Cryptosporidium como um grave patógeno humano foi firmemente demonstrado na década de 1980, em indivíduos portadores do vírus HIV que foram diagnosticados com criptosporidiose e vivenciaram uma infecção persistente, tornando-se um perigo à saúde pública, frequentemente envolvendo a disseminação do parasita para a hepatobiliar e as vias respiratórias, além de todo o trato gastrintestinal (CACCIÒ; PUTIGNANI, 2014).

Cryptosporidium é um membro do Filo Apicomplexa e, juntamente com Cyclospora, Isospora, Sarcocystis e Toxoplasma, compõem a Ordem Eucoccidiorida. Cryptosporidium e Sarcocystis diferem de outros coccidia, cujos oocistos requerem um período de maturação (esporulação) fora do hospedeiro para se tornar infeccioso. $O$ nome do gênero Cryptosporidium descreve o estágio transmissivo (o oocisto), que contém quatro esporozoítos que não estão contidos dentro de esporocistos (SMITH; NICHOLS; GRIMASON, 2005).

O gênero Cryptosporidium compreendia 14 espécies, juntamente com vários genótipos que mostram a diversidade genética, em alguns casos maiores do que a observada entre as espécies nomeadas (SMITH; NICHOLS; GRIMASON, 2005; CACCIÒ et al., 2005).

O abastecimento de água potável tem uma longa história associada a um amplo espectro de patógenos humanos, incluindo protozoários entéricos como Cryptosporidium. Cryptosporidium parvum, Cryptosporidium hominis e outras espécies relacionadas são reconhecidos por oferecer riscos à saúde humana, ocasionalmente, causando gastroenterite, portanto, representa um perigo para a qualidade da água (KEEGAN et al., 2008).

Cryptosporidium é um gênero de protozoários parasitas com espécies que infectam peixes, anfíbios, répteis, aves e mamíferos (FAYER, 2004). Também é reconhecido como um 
importante agente patogênico para uma ampla gama de hospedeiros vertebrados (ALDEYARBI; KARANIS, 2016).

Membros do gênero Cryptosporidium também causam gastroenterite e são frequentemente responsáveis por surtos de veiculação hídrica (HSU; YEH, 2003).

O ciclo de vida completo do parasito ocorre em um único hospedeiro e inclui estágios de reprodução assexuada e sexuada até a formação do oocisto, que é prontamente infectante (CACCIÒ; PUTIGNANI, 2014). A morfologia e o ciclo biológico do Cryptosporidium são bem mais complexos do que o de Giardia.

O ciclo de vida ocorre da seguinte forma, a infecção é adquirida através da ingestão de oocistos esporulados. No intestino delgado, esporozoítos, do oocisto aberto, se anexam às células epiteliais intestinais e se torna trofozoíto. O trofozoíto é submetido à replicação assexuada (merogonia), resultando na produção de merozoítos (oito merontes tipo 1). Os merozoítos, lançados no lúmen intestinal, infectam novas células do epitélio intestinal e daí origina-se o meronte tipo 2, que são caracterizados por 4 merozoítos. Estes merozoítos podem começar a fase sexuada (gametogonia) se diferenciando em microgametócito e macrogametócito. $\mathrm{O}$ microgametócito produz numerosas microgametas que são liberados no lúmen intestinal. Os microgametas se fundirão com um macrogameta e o zigoto resultante sofre esporogonia. Oocistos completamente esporulados (parede espessa) e de parede delgada são liberados no intestino (CACCIÒ; PUTIGNANI, 2014).

Os oocistos se formam de duas maneiras: um de parede espessa, que é excretado para o meio externo juntamente com as fezes, e um de parede delgada, que se rompe no intestino delgado e é responsável, acredita-se, pelos casos de auto-infecção (BASTOS; BEVILACQUA; KELLER, 2003).

Os oocistos de Cryptosporidium possuem morfologia esférica e são mais resistentes e menores (4 a $6 \mu \mathrm{m}$ ) que os cistos de Giardia e, portanto, de inativação e remoção mais difíceis. Os oocistos de Cryptosporidium podem sobreviver por até 1 ano a $4{ }^{\circ} \mathrm{C}$ na água do mar (CACCIÒ et al., 2003).

Diversos surtos ocorridos em todo o mundo têm demonstrado os efeitos sobre a comunidade de se consumir água de abastecimento contaminados com Cryptosporidium. $\mathrm{O}$ caso mais notável é de Milwaukee, EUA (1993) e, mais recentemente, em Galway, Irlanda (2007) (KEEGAN et al., 2008)

Um indivíduo infectado pode eliminar até $10^{2}$ oocistos/g de fezes e a dose infectante é de 1-30 oocistos. A transmissão fecal-oral entre pessoas (mecanismos mão-boca, fômites e alimentos) é reconhecida, bem como a potencial 
virulência do Cryptosporidium, especialmente em grupos populacionais imunodeprimidos. Também é reconhecida a veiculação hídrica da doença, via contato primário e consumo de água. A criptosporidiose é comprovadamente uma zoonose, sendo que os esgotos sanitários e as atividades agropecuárias constituem fatores inquestionáveis de contaminação de mananciais (BASTOS; BEVILACQUA; KELLER, 2003).

Em humanos, a criptosporidiose é caracterizada pela diarreia, síndromes gripais, malestar, dor abdominal, anorexia, náusea, flatulência, má-absorção intestinal, vômitos, febre baixa, perda de massa (SMITH et al., 2009).

Em indivíduos imunocompetentes, a criptosporidiose é autolimitante, mas pode se tornar crônica em indivíduos imunocomprometidos (PLUMMER; EDZWALD; KELLEY, 1995).

\subsection{Remoção de Giardia e Cryptosporidium no Tratamento de Água}

Dos diversos tipos de ETAs existentes, a tecnologia de ciclo completo é a mais utilizada no Brasil. Esta tecnologia consiste em um conjunto de processos e operações, tais como, coagulação, floculação, decantação ou flotação e filtração. Posteriormente à filtração, também são realizados os processos de desinfecção e ajuste do $\mathrm{pH}$.

Em razão das dimensões e características dos (oo) cistos, estes se comportam de forma semelhante às partículas coloidais. Eles são passíveis de serem removidas por técnicas usuais de tratamento de água, como a coagulação, floculação, decantação e filtração, desde que sejam submetidas ao rigoroso controle operacional (BASTOS; BRANDÃO; CERQUEIRA, 2009).

A maioria das pesquisas brasileiras que abordam a remoção dos parasitos Cryptosporidium e Giardia, em águas de abastecimento, faz uso do sulfato de alumínio como coagulante (MARQUES et al., 2005, LOPES, 2008). Recentemente, têm-se alterado este panorama, com a utilização do cloreto de polialumínio - PAC (PAVANELLI, 2001; CORRÊA et al., 2005; LOPES et al., 2009; FERREIRA FILHO; WAELKENS, 2009; JULIO et al., 2010; FERRARI; DE JULIO; DE JULIO, 2011; MACIEL, 2014; GIGLIO, 2015).

O PAC tem sido estudado e aplicado para o tratamento de águas, apresentando vantagens significativas em relação aos coagulantes tradicionalmente utilizados (LOPES, 2008). Segundo Pavanelli (2001), para a eliminação de substâncias coloidais, a eficácia do 
PAC é, em média, 1,5 a 2,5 vezes superiores em igualdade de dosagem em íon $\mathrm{Al}^{3+}$ aos outros sais de alumínio comumente utilizados.

A utilização do PAC normalmente elimina o uso de alcalinizante ou acidificante, reduzindo os custos (SILVA et al., 2009). Caetano e Lopes (2009) ressaltam a possibilidade de o PAC apresentar uma menor capacidade de produção de lodo quando comparado aos coagulantes tradicionalmente empregados no tratamento de águas de abastecimento.

A forma como os protozoários se apresentam na natureza, como cistos e oocistos, explica a sua significativa maior resistência à ação do cloro, cujo mecanismo predominante de inativação consiste na ruptura da parede celular.

Torna-se então, necessária a utilização de um desinfetante alternativo. Neste contexto, o ozônio é considerado um oxidante potente que se decompõe na água espontaneamente por meio de mecanismos complexos que envolvem a geração de radicais livres hidroxilas $\mathrm{OH}^{-}$ (DANIEL, 2001). Segundo Widmer et al., (2002) e Khalifa, El Temsahy e Abou (2001), o ozônio pode reduzir o risco associado à presença de protozoários em amostras ambientais.

A avaliação da remoção desses parasitos em laboratório requer a realização de ensaios de tratabilidade, pois visam definir as dosagens dos produtos químicos e os $\mathrm{pH}$ mais adequados à elevação da qualidade do efluente em uma estação de tratamento de água. Esses ensaios possibilitam, igualmente, definir os principais parâmetros de projeto nas etapas de mistura rápida, floculação, decantação ou flotação e filtração, além de avaliar as características dos resíduos gerados.

Embora a qualidade dos resultados dos ensaios de tratabilidade cresça com o emprego de unidades-piloto, os elevados custos da instalação as tornam muito raramente utilizadas mesmo em países desenvolvidos e quando são feitas, destina-se quase que exclusivamente às estações de grande porte (LIBÂNIO, 2008). Desta forma, esses ensaios são comumente realizados em reatores estáticos (jarteste e floteste). Nesta pesquisa foi utilizado o Floteste com água de estudo compatível com as recomendações indicadas por Valade et al., (2009), apresentadas nas Figuras 1 e 2. 


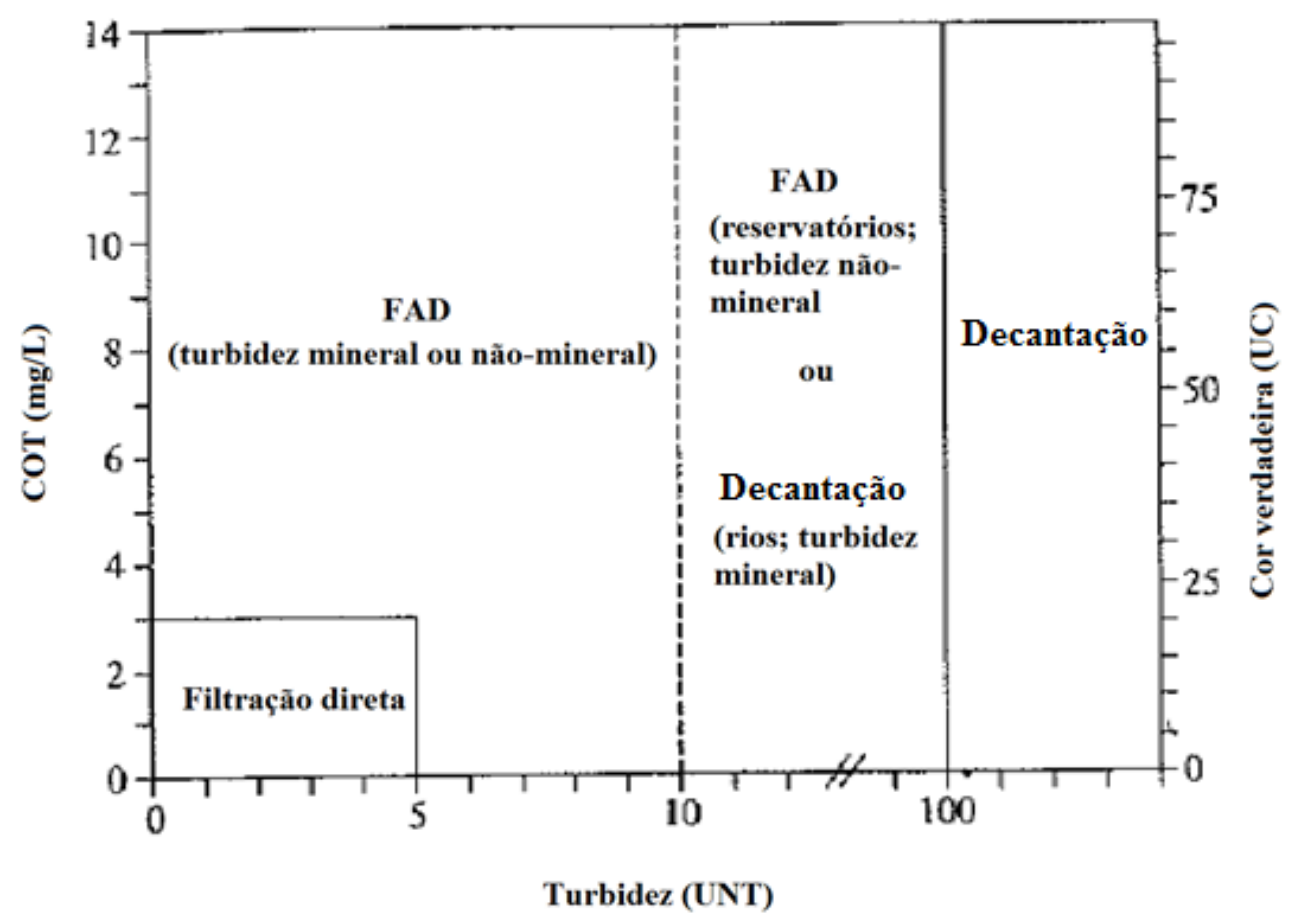

Figura 1: Diagrama de seleção da flotação baseado na qualidade da água bruta (condições médias) (VALADE et al., 2009).

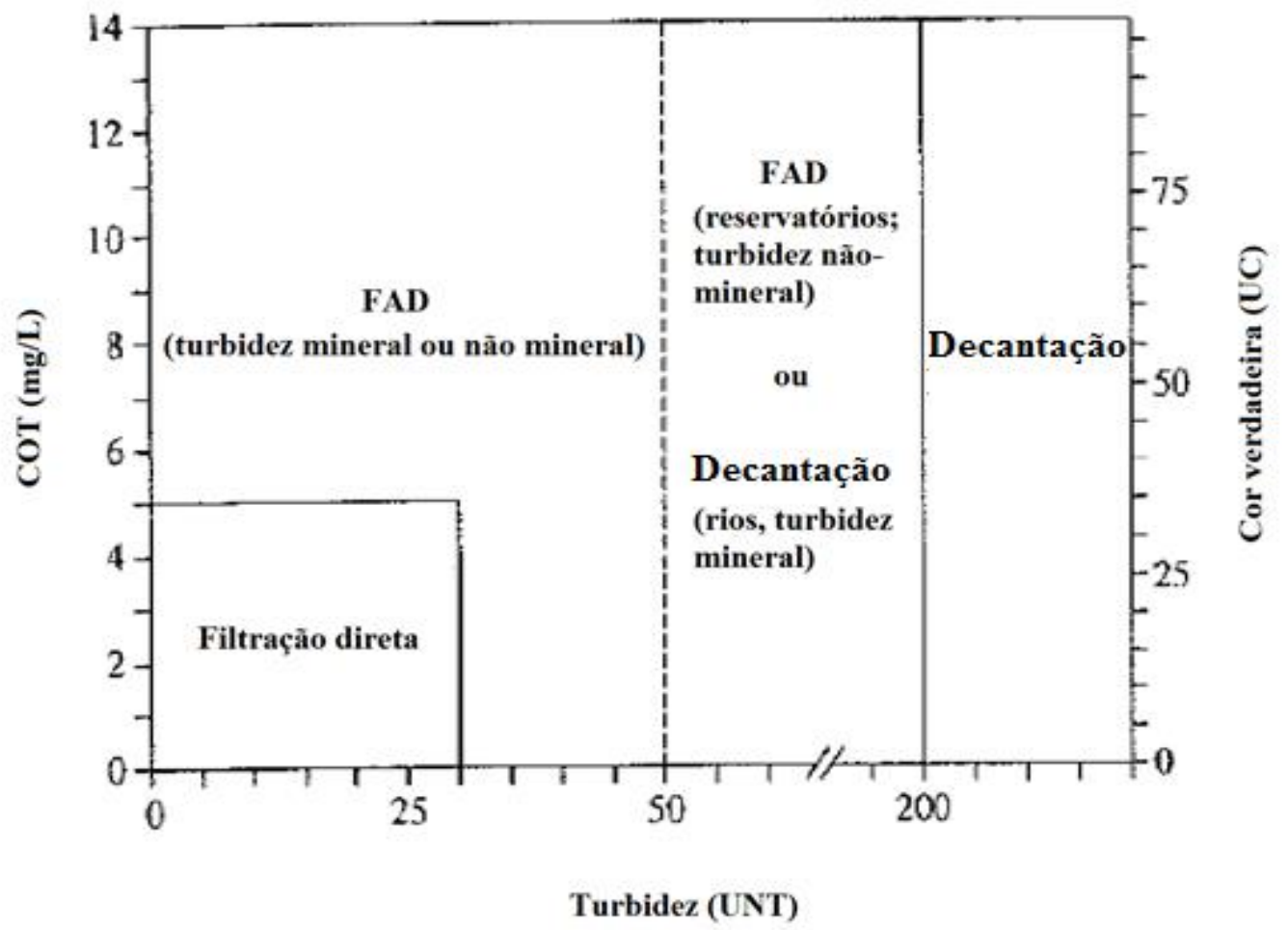

Figura 2: Diagrama de seleção da flotação baseado na qualidade da água bruta (condições máximas) (VALADE et al., 2009). 
As Figuras 1 e 2 indicam que a flotação pode ser utilizada em águas com turbidez de até 200 UNT e com valores altos de cor verdadeira e carbono orgânico total - COT.

Existem vários motivos para escolher a flotação por ar dissolvido - FAD ao invés da decantação para a clarificação da água, de acordo com Edzwald e Harrhoff (2011), por exemplo, baixa carga de partículas para os filtros, alta remoção de algas, remoção de gosto, odor, cor, alta remoção de patógenos, lodo mais concentrado, tanques de floculação pequenos e menores áreas em planta. Os pesquisadores também reportam que, a FAD é mais eficiente em remover cistos de Giardia e oocistos de Cryptosporidium do que a sedimentação.

No processo de flotação, existem maneiras diferentes de formação das bolhas, os três tipos principais são: flotação eletrostática, flotação por ar disperso e flotação por ar dissolvido (EDZWALD; HARRHOFF, 2011). Na FAD, as bolhas são produzidas pela redução da pressão da água saturada com ar.

Assavasilavasukul et al., (2008) avaliaram o efeito da concentração de patógenos na remoção de Crypstosporidium e Giardia com o tratamento de água convencional com decantação e obtiveram os seguintes resultados. A média de remoções de log de oocistos de Crypstosporidium foi de 3,2 $\pm 0,5$ e de $1,1 \pm 0,3$ no tratamento com concentração inicial de $7,0 \times 10^{4}$ e $5,3 \times 10^{2}$ oocistos/L, respectivamente. Para a média de remoção de cistos de Giardia, o tratamento convencional foi capaz de remover 3,8 $\pm 0,1 \log$ e 1,5 $\pm 0,4 \log$, com concentração inicial de $6,1 \times 10^{4}$ e $3,9 \times 10^{2}$ cistos/L na água de estudo. Verifica-se que a remoção de oocistos de Cryptosporidium e cistos de Giardia, através do tratamento convencional, aumenta em função da concentração inicial de patógenos. Também foi observado que, os cistos de Giardia são removidos com mais eficiência do que os oocistos de Cryptosporidium - este fato está relacionado às maiores dimensões dos cistos.

Outro estudo de tratamento de água utilizando ciclo completo com decantação em escala de bancada, realizado por Maciel e Sabogal-Paz (2016), reportou valores de remoções por volta de $2 \log$ para os protozoários, Giardia spp. e Cryptosporidium parvum em água com turbidez elevada, valores positivos de potencial zeta, utilizando o PAC como coagulante.

As pesquisas supracitadas utilizaram a decantação para remoção de protozoários e agora serão citados alguns estudos que analisaram a flotação como processo para remoção dos parasitos, diante das vantagens deste tipo de operação.

Edzwald e Harrhoff (2011) reportaram que cistos de Giardia e oocistos de Cryptosporidium possuem baixa densidade, em torno de $1070 \mathrm{~kg} \cdot \mathrm{m}^{-3}$, e quando incorporados 
aos flocos, após a coagulação e floculação, pode dificultar a sedimentação. Assim, a flotação é o processo ideal para remover esses protozoários.

Keegan et al., (2008) utilizaram em sua pesquisa com água bruta, sulfato de alumínio como coagulante e os desinfetantes utilizados foram o hipoclorito de sódio e monocloramina, em que, o tratamento de água utilizado foi a flotação por ar dissolvido. A FAD para a remoção de oocistos foi avaliada com concentrações de alumínio na faixa de 40 a $100 \mathrm{mg} . \mathrm{L}^{-1}$ e a remoção de oocistos foi determinada com ensaios em triplicata. Para cada dose testada (40-100 mg. $\left.\mathrm{L}^{-1}\right)$ foram alcançadas remoções de oocistos maiores que $99 \%$ (2 log). A remoção de oocistos foi eficiente utilizando tanto o tratamento convencional quanto o processo de FAD.

Plummer, Edzwald e Kelley (1995) analisaram água de abastecimento com inóculo de oocistos, que possuía água de alta qualidade com baixa turbidez e matéria orgânica e avaliaram a eficiência da FAD e da sedimentação na remoção de oocistos de Cryptosporidium. Os pesquisadores obtiveram resultados como, remoção de oocistos superior a $2 \log$ utilizando a FAD e várias condições, entre elas, dosagem de coagulante de $3-5 \mathrm{mg} . \mathrm{L}^{-}$

${ }^{1}$ de cloreto férrico, valores de pH entre 4,3 e 6,2, tempo de floculação inferior a 5 min e taxa de recirculação entre 6 e $10 \%$. Enquanto que, na sedimentação, a remoção foi próxima de 1 $\log$, utilizando dosagem de coagulante de $4 \mathrm{mg} . \mathrm{L}^{-1}$ de cloreto férrico. Também reportaram que, a coagulação e as condições da FAD que reduzam a turbidez e aumentem a remoção de matéria orgânica são situações que aumentam a remoção de log de Cryptosporidium.

Empresas responsáveis pelo abastecimento de água, principalmente, as que utilizam águas superficiais, devem utilizar múltiplas barreiras para eliminar oocistos de Cryptosporidium e cistos de Giardia da água, o mais recomendado é a proteção dos mananciais e a inclusão de filtração. A filtração tem sido apontada como o mais efetivo meio para a remoção de cistos e oocistos (LADEIA; HÉLLER; VIEIRA, 2005).

Swertfeger et al., (1999) avaliaram a filtração para remoção de cistos e oocistos e todos os meios filtrantes obtiveram valores médios de 2,7 a 4,5 log de remoção para cistos de Giardia e de 2,7 a 3,9 log de remoção para oocistos de Cryptosporidium. Estes resultados demonstraram que a remoção foi melhor que a esperada e similar com estudos que utilizaram filtração direta ou convencional. 
Entretanto, Smith e Grimason (2003), relatam que, mesmo utilizando os mais eficientes processos físico-químicos adequadamente combinados não são suficientes para remover totalmente os (oo) cistos.

Para isso, é necessária uma etapa de desinfecção, visto que esses protozoários apresentam elevada resistência aos sistemas de tratamento de água convencionais, como à desinfecção com cloro. Este tópico será abordado em seguida.

\subsection{Ozonização}

Em um sistema de tratamento de água ou esgoto, o processo de desinfecção é um dos mais importantes, pois tem como finalidade assegurar a proteção à saúde publica. É nesta etapa que ocorre a inativação dos microrganismos patogênicos presentes no efluente, minimizando o risco de proliferação de doenças de veiculação hídrica para a sociedade que faz uso dos recursos hídricos e para o meio ambiente (COSTA, 2007).

Cerca de $80 \%$ da desinfecção no mundo, é efetuada por meio do cloro por não ser tóxico para o homem ou qualquer outro animal; ser tóxico em baixa concentração para os organismos-alvo; ser solúvel em água; é eficaz nas condições de temperatura e pH encontrados no meio líquido; possui custo razoável em relação aos volumes de água ou efluente a desinfetar; não apresenta elevado risco aos operadores e permite fácil medida e controle de sua concentração (LAPOLLI et al., 2003).

Entretanto, a adição do cloro pode ocasionar efeitos secundários indesejáveis, pois ao reagir com a matéria orgânica pode levar à formação de compostos organoclorados, trihalometanos (THM) e ácidos haloacéticos, que são mutagênicos, tóxicos e carcinogênicos em água (COSTA, 2007; DA SILVA et al., 2011). Além disso, o cloro não é um oxidante suficientemente poderoso para eliminar completamente organismos mais resistentes como os vírus e protozoários.

Métodos de desinfecção alternativos como o tratamento com o ozônio, que é considerado um método promissor para a desinfecção de efluentes, têm recebido maior atenção e deve ser melhor estudado (SILVA et al., 2010).

As primeiras evidências do conhecimento do ozônio, quando seu odor característico foi detectado pela primeira vez foi em 1781, porém, somente em 1867 sua fórmula química $\left(\mathrm{O}_{3}\right)$ foi descoberta. No ano de 1886, a propriedade desinfetante do ozônio foi reconhecida. O ozônio foi utilizado pela primeira vez como desinfetante no tratamento de água em 1893, na Holanda, não tendo sido muito utilizado no Brasil. Em 1906 a Estação de Tratamento de 
Água Bon Voyage, na França, foi apontada como a primeira estação a utilizar o ozônio para desinfecção (SANCHES, 2003; COSTA, 2007; SOARES, 2007).

O ozônio é agente oxidante poderoso, atuando como desinfetante alternativo ao cloro, muito eficiente na inativação de bactérias coliformes, vírus, colifagos, cistos de Giardia e oocistos de Criptosporidium, ambos protozoários resistentes ao cloro (SOUZA, 2006; DA SILVA et al., 2011; LAPOLLI et al., 2003).

O ozônio é um potente oxidante, capaz de oxidar compostos orgânicos e inorgânicos na água, os quais exercerão uma demanda do oxidante antes de ocorrer a desinfecção (DANIEL, 2001).

Os principais mecanismos de inativação de microrganismos patogênicos por agentes químicos, como o ozônio, são: pela destruição da organização celular por ataque aos principais constituintes da célula; pela interferência no metabolismo energético tornando as enzimas não funcionais e; pela interferência na biossíntese e no crescimento prejudicando a síntese de proteínas, ácidos nucléicos, coenzimas ou parede celular (SILVEIRA, 2004).

O ozônio age nos constituintes da membrana citoplasmática, nos sistemas enzimáticos e nos ácidos nucléicos dos microrganismos.

O ozônio atua inicialmente na membrana celular, sendo a superfície da célula microbiana o primeiro alvo a ser atingido. A ação antimicrobriana é proveniente da oxidação de glicoproteínas ou glicolipídeos da parede celular, que por sua vez, altera a permeabilidade e causa sua rápida lise. Em adição, o ozônio ataca também grupos sulfidrila de enzimas, que ocasiona o colapso da atividade enzimática celular e além disso, interage com substâncias presentes no citoplasma e no núcleo, degradando purinas e pirimidinas do DNA, sendo este um dos fatores responsáveis pela morte celular (LANGLAIS; RECKHOW; BRINK, 1991; CAMEL; BERMOND, 1998; SILVEIRA, 2004; DA SILVA et al., 2011).

Em solução aquosa, o ozônio pode atuar em vários compostos, por meio de reação direta com ozônio molecular ou através de reações indiretas com os radicais formados quando o ozônio se decompõe na água (LANGLAIS; RECKHOW; BRINK, 1991).

A produção comercial do ozônio é realizada pelo "processo corona". Este processo consiste em aplicar uma corrente elétrica em um fluxo gasoso de ar ou oxigênio. O campo elétrico aplicado fornece energia suficiente aos elétrons para que estes rompam as duplas ligações da molécula de $\mathrm{O}_{2}$, gerando dois átomos de oxigênio. Esses átomos de oxigênio reagem com outra molécula de $\mathrm{O}_{2}$ para formar as moléculas de $\mathrm{O}_{3}$. Como ele não pode ser 
armazenado nem transportado, deve ser gerado no próprio local de consumo (LAPOLLI et al., 2003).

O uso do ozônio tem sido pesquisado por diversos autores como, Wickramanayake et al., (1984), Finch et al., (1993), Widmer et al., (2002) e Khalifa, El Temsahy e Abou (2001), entre outros, na inativação dos protozoários supracitados e, outros patógenos.

Widmer et al., (2002) avaliaram a inativação de cistos de Giardia com concentração de ozônio inicial de 1,5 mg. $\mathrm{L}^{-1}$, valor de CT de 1,5 mg.min. $\mathrm{L}^{-1}$ e resultou em mais de 3 log de inativação.

Finch et al., (1993) avaliaram a inativação de cistos com ozônio e reportaram que para os valores de CT de 0,24; 0,45 e 0,86 mg.min. $\mathrm{L}^{-1}$, foram obtidos valores de 2, 3 e 4 log de inativação de cistos de Giardia muris, respectivamente. Para cistos de Giardia lamblia valores de $\mathrm{CT}$ de 0,$65 ; 1,23$ e 2,57 mg.min. $\mathrm{L}^{-1}$ resultaram em 2, 3 e 4 log de inativação, respectivamente e utilizaram a técnica de infectividade in vivo.

Wickramanayake et al., (1984), desenvolveram um estudo avaliando a inativação de cistos de Giardia na água utilizando ozônio. O estudo avaliou a inativação com pH 7 e temperatura de 5 e $25^{\circ} \mathrm{C}$, e os valores de CT utilizados foram de 0,53 e 0,17 mg.min. $\mathrm{L}^{-1}$, respectivamente e para ambas as condições, alcançaram $2 \log$ de inativação de cistos de Giardia, utilizando a técnica de excistação.

Labatiuk et al., (1991) pesquisaram sobre a inativação de cistos com ozônio e alcançaram até $3 \log$ de inativação de cistos de Giardia muris, com Ct de 0,5 mg.min.L-1 utilizando $\mathrm{pH} 6,7$ e temperatura de $22^{\circ} \mathrm{C}$ e avaliaram os corantes vitais, excistação in vitro e ensaios in vivo.

Korich et al., (1990) avaliaram vários desinfetantes, entre eles, o ozônio, utilizando Ct de 5 mg.min. $\mathrm{L}^{-1}$ e alcançaram inativação de $2 \log$ de oocistos de Cryptosporidium parvum com a técnica de excistação in vitro.

Soares (2007) utilizou dosagens de 10 e $20 \mathrm{mg} . \mathrm{L}^{-1}$ e tempos de contato de 5, 10, 15 e 20 min em esgoto sanitário previamente tratado em reator UASB para avaliar à inativação dos microrganismos indicadores e obteve resultados como, $C$. perfringens apresentou-se como o mais resistente à ação bactericida do ozônio seguido por E.coli e colifagos. Foram inativados 1,7 log de C. perfringens $\left(\mathrm{Ct}=80\right.$ mg.min. $\left.\mathrm{L}^{-1}\right) ; 6,1 \log$ de E.coli $\left(\mathrm{Ct}=133\right.$ mg.min. $\left.\mathrm{L}^{-1}\right)$; e 100 $\%$ de colifagos $\left(\mathrm{Ct}=38 \mathrm{mg} \cdot \mathrm{min} \cdot \mathrm{L}^{-1}\right)$.

Silva et al., (2010) pesquisaram sobre a desinfecção de efluente de esgoto sanitário com ozônio e utilizaram dosagens de 5, 8 e $10 \mathrm{mgO}_{3} \mathrm{~L}^{-1}$ e tempos de contato de 5,10 e 15 min 
e obtiveram uma faixa de inativação de coliformes totais de 2,00 a 4,06 log e o intervalo de inativação para E.coli foi de 2,41 a 4,65 log.

Posteriormente à ozonização, alguns cálculos são realizados para se obter a dosagem de ozônio e alguns parâmetros principais serão descritos abaixo, de acordo com Van Leeuwen (2015), que são:

\section{Taxa de alimentação do ozônio}

Este tópico deve ser um balanço de massa simples sobre o reator de ozonização. O primeiro passo é determinar a taxa de alimentação do gás a partir do gerador de ozônio numa determinada configuração. Isto pode ser medido através da determinação da concentração de ozônio na fase gasosa e o método mais comum, é o descrito por Rakness et al., (1997) que mede a concentração de gás através de uma reação química ou utilizando um medidor de UV comercial, calibrado com colorimetria redox. A concentração da fase gasosa, multiplicada pela taxa de fluxo de gás de alimentação, definirá a taxa de alimentação de ozônio. A unidade é definida em unidades de massa de ozônio por unidade de tempo.

\section{Dosagem de Ozônio Aplicada}

A dosagem aplicada pode ser calculada multiplicando o período de ozonização com a taxa de aplicação e dividida pelo volume da amostra, e geralmente é expressa em mg.L $\mathrm{L}^{-1}$, em que o volume representa o volume da amostra.

\section{Dosagem de Ozônio Consumido}

A dosagem consumida deve ser calculada sempre que possível. Isto pode ser realizado pela ozonização da amostra em um recipiente fechado e passando o gás que sai através de um dispositivo de medição para determinar a quantidade de ozônio não utilizada. A quantidade de ozônio não utilizada após qualquer período de ozonização deve ser subtraída do ozônio aplicado sobre o mesmo período de cálculo da dosagem de ozônio consumida. Este será novamente expressa em mg. $\mathrm{L}^{-1}$.

\subsection{Controle da Qualidade Analítica dos Métodos de Avaliação de Protozoários em Amostras de Água}

Para realizar a avaliação de protozoários é necessária uma etapa que verifique o desempenho do protocolo adotado na recuperação dos (oo) cistos, de acordo com USEPA (2012); neste contexto, as etapas do controle de qualidade citado são: 
a) Precisão inicial e recuperação na água de estudo: realiza-se a contaminação artificial de 4 amostras da água de estudo com suspensões com número conhecido de oocistos de Cryptosporidium spp. e cistos de Giardia spp. (p.ex: EasySeed ${ }^{\circledR}$ ). Estas amostras são processadas empregando o protocolo adotado para as análises. Também é processada uma amostra livre de contaminação artificial que é considerado como controle-negativo, cujo resultado atestará as boas condições laboratoriais. A partir dos resultados gerados são calculados a média da porcentagem de recuperação dos protozoários e o coeficiente de variação $(\mathrm{CV})$. Esses resultados são comparados aos padrões estabelecidos pelo Método 1623.1 (USEPA, 2012). O desempenho é considerado aceitável se a média e o CV estiverem dentro do critério estabelecidos pelo Método 1623.1. Se a média obtida e o CV estiverem dentro deste critério de aceitação, o desempenho do protocolo é considerado aceitável e as análises poderão ser iniciadas. Caso contrário, caracteriza-se desempenho inaceitável, portanto, o problema deverá ser corrigido e o teste será repetido até se enquadrar nos limites aceitáveis.

b) Diagnóstico e localização de erros: quando os resultados obtidos estiverem fora dos limites estabelecidos e a causa não for determinada, serão realizados alguns procedimentos analíticos para avaliar o desempenho dos procedimentos adotados. Esses procedimentos consideram a checagem do sistema de microscopia e do anticorpo analisado, verificando a iluminação do microscópio e examinando alíquotas da suspensão controle-positivo presentes no kit comercial (kit Merifluor $^{\circledR}$ ) observando que mais de $50 \%$ dos (oo) cistos apresentem fluorescência compatível com os padrões previamente estabelecidos. A verificação das etapas de filtração, concentração e eluição também é considerada, isto através da contaminação artificial em água reagente e execução dessas etapas seguidas da visualização, observando-se a integridade dos (oo) cistos durante a leitura das lâminas.

\subsection{Métodos de Avaliação de Giardia e Cryptosporidium em Amostras de Água}

Os métodos de avaliação de protozoários em águas naturais representam um desafio, pois as metodologias empregadas estão sujeitas a grande variabilidade e baixa reprodutibilidade, proporcionalmente ao aumento da turbidez da água. Além disso, os custos são elevados. O protocolo para identificação e detecção de (oo) cistos envolve as etapas de: i) amostragem e concentração, ii) purificação e separação; e iii) avaliação e identificação.

\subsubsection{Amostragem e Concentração}


A concentração da amostra de água tem por finalidade recuperar ou capturar os (oo) cistos. O volume de amostra a ser analisado depende da concentração esperada de (oo) cistos. Esta primeira etapa de concentração basicamente é realizada por meio da floculação em carbonato de cálcio ou através da filtração de volumes variados.

Na floculação com carbonato de cálcio ocorre adição de produtos químicos na água com agitação, posterior sedimentação dos flocos, em seguida, o sobrenadante é descartado e o precipitado formado é dissolvido e concentrado por sucessivas centrifugações, onde o pellet obtido é examinado por microscopia de fluorescência (VESEY et al., 1993). Este método apresenta vantagens, tais como, o baixo custo quando comparado ao Método 1623.1, é aplicável em amostras com elevada turbidez e eficiência de recuperação relatada na literatura ao redor de 30,0 \% a 40,0 \%. O método apresenta algumas limitações, de acordo com Franco et al., (2012) e Cantusio Neto (2008), como perda de organismos no sobrenadante, variações nas concentrações dos reagentes e do $\mathrm{pH}$ causam uma diminuição do número de organismos floculados, o sedimento resultante é rico em material particulado, que interfere na RID e acarreta resultados falso-positivos e o pH 10 requerido para a etapa de floculação pode causar alterações morfológicas levando a resultados falso-negativos.

Em relação ao método empregando a filtração, os mais utilizados no Brasil são o sistema Filta-Max ${ }^{\circledR}$ e a filtração em membrana. A filtração com o Sistema Filta-Max ${ }^{\circledR}$ é aceita pelo Método 1623.1 (USEPA, 2012). A amostra é filtrada, depois a espuma filtrante é retirada do módulo do filtro, acondicionada em saco plástico e lavada (com solução tampão de fosfato contendo Tween 80 e, posteriormente, comprimida. O líquido resultante é centrifugado a 1250 x g por 15 min. A principal limitação da metodologia é o elevado custo, segundo Franco et al., (2012). O método também apresenta maior complexidade laboratorial, necessita de recursos humanos especializados e é influenciado pela turbidez da amostra.

O método de filtração em membranas de ésteres mistos de celulose de porosidade nominal de $3 \mu \mathrm{m}$ e $47 \mathrm{~mm}$ de diâmetro foi desenvolvido por Franco, Eberhardt e Cantusio Neto (2001). Apresenta como vantagens o menor tempo de processamento laboratorial, mantém a morfologia dos oocistos e possui menor custo. A amostra de água é filtrada utilizando uma bomba de vácuo com fluxo de 4 L.min ${ }^{-1}$ e sistema porta-filtro. Após a filtração, o material é eluído a partir da superfície da membrana mediante extração mecânica com solução de Tween $80(0,01 \%)$. O material resultante é concentrado por dupla centrifugação (1.050 x g; 10 min.) (FRANCO; BRANCO; LEAL, 2012). A maior limitação 
da técnica de filtração em membranas é o efeito da alta turbidez, que pode levar ao processamento de um maior número de membranas.

\subsubsection{Purificação e Separação}

Segundo Medeiros (2010), a etapa é utilizada para isolar organismos-alvo de partículas interferentes na detecção. Esta etapa pode ser realizada por: i) flutuação: produtos químicos são utilizados para gerar diferentes gradientes de densidade, sendo a solução saturada de sacarose a mais utilizada; ii) separação imunomagnética (IMS): utilização de anticorpos monoclonais específicos e de alta afinidade ligados à superfície de esferas magnetizadas que permite a captura de (oo) cistos. Um imã é usado para separar os organismos, associados às esferas, de outros fragmentos e partículas. Depois existe uma etapa de dissociação, térmica ou ácida, que permite separar os (oo) cistos das esferas; e iii) clarificação com éter: uma segunda centrifugação é proposta com adição de éter previamente, em banho de gelo.

\subsubsection{Avaliação e Identificação}

Medeiros (2010) descreve os seguintes métodos para avaliar e identificar os protozoários: i) Reação de Imunofluorescência Direta - RID: utiliza anticorpos monoclonais marcado com corante fluorogênico FITC (isotiocianato de fluoresceína) que age diretamente contra antígenos de (oo) cistos, com leitura por microscopia de imunofluorescência; e ii) Polymerase Chain Reaction - PCR: permite a detecção da quantidade de DNA e/ou RNA identificando o protozoário analisado.

\subsection{Métodos de Avaliação de Viabilidade e Infectividade de Protozoários}

De acordo com Smith e Grimason (2003), posteriormente à identificação dos parasitos, é necessário determinar a viabilidade e infectividade, que se refere à eficiência do tratamento utilizado. A viabilidade está relacionada à atividade metabólica ou integridade da parede celular dos (oo) cistos (SANTOS; CANTUSIO NETO; FRANCO, 2008) e pode ser determinada através dos seguintes métodos, descritos por Medeiros (2010): i) excistação (desencistamento) in vitro: os (oo) cistos são forçados a se excistarem ao serem expostos ao meio de cultura específico; ii) inclusão/exclusão de corantes fluorogênicos: corantes como o 
4',6-diamino-2fenil-indol (DAPI) e o iodeto de propídio (IP) são os mais utilizados; e iii) avaliação do dano na parede celular dos protozoários conforme a técnica de visualização por Reação da Imunofluorescência Direta (RID), realizada por Fagnani (2010).

A infectividade define a capacidade de o parasito completar seu ciclo de vida em hospedeiro susceptível, com a produção e eliminação de novas formas de resistência nas fezes (FRANÇA, 2007). Medeiros (2010) descreve os seguintes métodos: i) cultivo celular: que é a única técnica utilizada para avaliar a infectividade apenas para Cryptosporidium hominis, pois está espécie não infecta os animais mais utilizados em experimentos de infectividade (ratos e camundongos) e apresenta o mesmo nível de infectividade que o Cryptosporidium parvum no cultivo celular. Em relação a Giardia spp., como este não é um protozoário invasivo (habita o lúmen intestinal do seu hospedeiro), o cultivo celular não pode ser realizado para análise da infectividade (SANTOS, 2007) e ii) infectividade animal: baseia-se na inoculação de (oo) cistos em animais de laboratório para depois realizar o monitoramento dos efeitos dos parasitos na saúde do animal.

Recentemente, o corante vital Propidium monoazide - PMA associado ao Método molecular de PCR (Polymerase Chain Reaction) tem-se mostrado uma solução para a geração de resultados rápidos e confiáveis sobre a infectividade de formas parasitárias detectadas em água.

O PMA é um corante fotoativo que penetra em células mortas ou com danos na membrana, não sendo incorporado em células com membrana celular intata, ou seja, potencialmente viáveis. Uma vez dentro da célula, o corante se une ao DNA que após ser exposto à luz, fluoresce. Esta fotoativação resulta em um complexo DNA-PMA que, uma vez formado, não permite que o DNA da célula alvo seja amplificado pela técnica de PCR (HEIN et al., 2007; BRESCHIA et al., 2009).

Os corantes fluorogênicos têm sido aceitos como um meio sensível para determinar a viabilidade celular, em uma variedade de células, que variam de protozoários até células de mamíferos (SCHUPP; ERLANDSEN, 1987).

Para o estudo da desinfecção da água filtrada com inóculo de protozoários, matriz desta pesquisa, foi imprescindível inferir a viabilidade dos (oo) cistos, através do emprego de corantes vitais. Dois corantes fluorogênicos, o Azul de Tripano e o Iodeto de Propídio - IP foram utilizados e este último juntamente com DAPI e anticorpos monoclonais FITC.

\subsubsection{Teste de Viabilidade Utilizando o Azul de Tripano}


O teste de exclusão do corante é usado para determinar o número de células viáveis presentes em uma suspensão de células. Baseia-se no princípio de que as células vivas possuem membranas celulares intactas que excluem determinados corantes, como o azul de tripano, enquanto que as células mortas não. Neste teste, uma suspensão de células é simplesmente misturada com o corante e, em seguida, examinadas em microscopia de campo claro para determinar se células tomam ou não o corante. No protocolo, que pode ser encontrado na bula do produto ou no Current Protocols in Immunology (1997) uma célula viável terá um citoplasma claro ao passo que uma célula não viável terá um citoplasma azul.

A exclusão do corante é uma técnica simples e rápida de medir a viabilidade celular, mas é sujeita ao problema de que a viabilidade está sendo determinada indiretamente a partir da integridade da membrana celular. Assim, é possível que a viabilidade de uma célula seja comprometida (como medida pela capacidade de crescer ou funcionar), embora a integridade da membrana seja mantida (pelo menos temporariamente).

Por outro lado, a integridade da membrana da célula pode ser ainda anormal, pois pode ser capaz de reparar-se e tornar-se totalmente viável. Outro problema potencial é que, devido à absorção do corante ser avaliada subjetivamente, pequenas quantidades absorvidas, indicativas de lesão celular, podem passar despercebidas.

O azul de tripano, como descrito no Current Protocols in Immunology (1997), tem como vantagem ser de fácil execução, de baixo custo e pode ser realizado em 5 a 10 min., no entanto, o tempo de leitura da lâmina é curto, fato que pode ser limitante à técnica, em função do número de organismos-alvo presentes na amostra. Além desse fator, outro problema decorrente do uso deste corante, é a dificuldade da leitura em campo claro, pois os organismos são de difícil detecção e muitas vezes, podem ser confundidos com pequenas bolhas, ou sujidades encontradas nas lâminas.

\subsubsection{Teste de Viabilidade Utilizando o Iodeto de Propídio}

A capacidade de determinar rapidamente a viabilidade dos cistos e oocistos ambientalmente resistentes no abastecimento de água é de grande significância para fins regulatórios, bem como para fins epidemiológicos (KORICH et al., 1990).

A capacidade de distinguir oocistos e cistos viáveis de não viáveis poderia auxiliar na interpretação ecológica da presença de oocistos/cistos no ambiente (DOWD; PILLAI, 1997). 
As determinações de viabilidade usando excistação e infectividade animal estão atualmente fora do alcance de rotina dos serviços públicos de água, uma vez que são extremamente caros e muitas vezes não confiáveis devido às suas variabilidades. Existem alguns relatórios que sugerem a utilização de corantes vitais e outras abordagens para determinar a viabilidade, ultrapassando assim a necessidade dos métodos anteriormente citados (DOWD; PILLAI, 1997).

O corante fluorogênico vital IP é baseado na permeabilidade da membrana, ou seja, que permite ou não a inclusão do corante, portanto, o IP não consegue atravessar a bicamada lipídica da parede do (oo) cisto intacta, por ser uma molécula muito grande, ocorrendo inclusão do corante quando ela está danificada, podendo ser visualizada com fluorescência vermelha com excitação em comprimento de onda de 500 nm (APHA; AWWA; WEF, 2012).

O corante de inclusão DAPI é o mais utilizado como teste confirmatório da morfologia dos (oo) cistos, pois favorece a visualização do núcleo dos organismos (SANTOS, 2007). Quando observados, em microscópio, os cistos de Giardia apresentam núcleo com coloração cor azul-céu, enquanto que os oocistos de Cryptosporidium apresentam coloração azul-céu intensa e visualização de 1 a 4 núcleos em apenas 1 oocisto (SANTOS, 2007).

$\mathrm{O}$ reagente vem sendo mencionado em diversos artigos científicos quanto à viabilidade de cistos de Giardia e oocistos de Cryptosporidium (SCHUPP; ERLANDSEN, 1987; CAMPBELL et al., 1992; DOWD; PILLAI, 1997; ROBERTSON et al., 2000; VERGARA-CASTIBLANCO et al., 2000; FREIRE-SANTOS et al., 2000; BETANCOURT et al., 2003; OLVERA et al., 2008), entre outros.

Schupp e Erlandsen (1987) mostraram que a inclusão de iodeto de propídio (IP) em cistos e oocistos indica que as membranas foram danificadas ou rompidas (inviabilidade) e que a inclusão do IP está bem relacionada com a não infecciosidade como determinado por estudos de infectividade animal. Os pesquisadores também relatam que o desenvolvimento deste teste rápido e barato deve facilitar o teste dos efeitos de vários agentes químicos e de fatores ambientais sobre a viabilidade de cistos de Giardia.

Campbell et al., (1992) relataram a aplicabilidade da utilização de uma combinação dos dois corantes vitais, o IP e o DAPI para diferenciar oocistos de Cryptosporidium viáveis e não viáveis. Eles mostraram que a inclusão de IP se correlaciona bem $\left(\mathrm{r}^{2}=0,997\right)$ com a viabilidade avaliada pelo método de excistação.

Labatiuk et al., (1991) compararam a infectividade animal, a excistação, e um corante fluorogênico (fluoresceína diacetato de brometo de ethidium) como uma medida de 
inativação de cistos de Giardia spp. Relataram que houve uma diferença significativa entre os métodos testados e a viabilidade dos corantes fluorogênicos foi superestimada em comparação aos resultados de infecciosidade.

Vergara-Castiblanco et al., (2000) pesquisaram sobre a viabilidade de dois tipos de Cryptosporidium parvum, provenientes da Colômbia e Espanha e analisaram os métodos de excistação in vitro, inclusão/exclusão de dois corantes fluorogênicos vitais (DAPI e IP) e ensaio de infectividade. Os pesquisadores relatam que não foi possível obter uma boa correlação entre excistação in vitro, inclusão/exclusão de corantes vitais e na infectividade in vivo para os parasitos da Colômbia, enquanto que os dados obtidos com o da Espanha indicaram uma forte correlação entre a eficiência de excistação, os corantes vitais e a infectividade. 


\section{MATERIAL E MÉTODOS}

Para o desenvolvimento das atividades foi utilizada a infraestrutura existente no Laboratório de Tratamento Avançado e Reuso de Água - LATAR do Departamento de Hidráulica e Saneamento da Escola de Engenharia de São Carlos, Universidade de São Paulo - SHS/EESC/USP. A pesquisa foi realizada conforme atividades descritas a seguir.

\subsection{Preparação da Água de Estudo}

A água de estudo foi preparada com água do poço da EESC/USP. Um volume de aproximadamente $2000 \mathrm{~L}$ foi armazenado em dois reservatórios de $1000 \mathrm{~L}$, previamente desinfetados com hipoclorito de sódio a $0,5 \%$ por 7 dias. Os reservatórios foram cobertos com lona plástica preta para evitar a proliferação de algas. A água de estudo apresentava, aproximadamente, $50 \mathrm{uT}$ de turbidez e $80 \mathrm{uH}$ de cor verdadeira. $\mathrm{O}$ aumento da turbidez aconteceu pela adição de caulinita (Caolim, Pheur - Sigma-Aldrich ${ }^{\circledR}$ - Fluka-60609) e a presença de cor verdadeira pela adição de ácido húmico (Sal Sódico, Grau Técnico SigmaAldrich $\left.^{\circledR}-\mathrm{H} 16752\right)$.

A água do poço, previamente armazenada, era transferida para uma bombona de $200 \mathrm{~L}$ através de uma bomba submersível, onde os reagentes citados eram adicionados e, posteriormente, a mistura era homogeneizada em misturador elétrico (Figura 3).

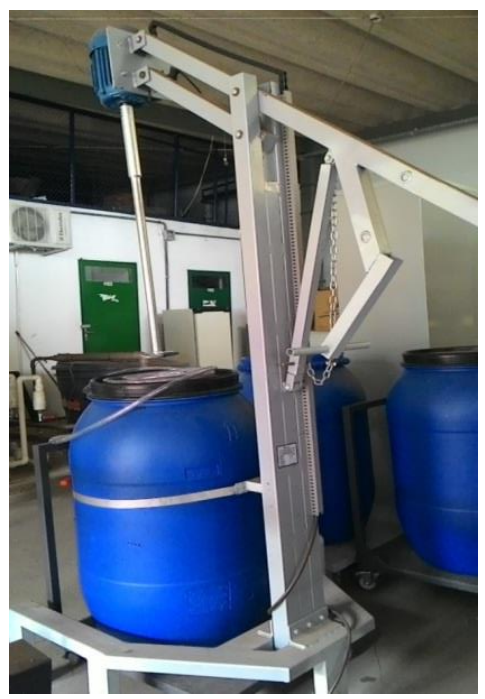

Figura 3: Bombona de $200 \mathrm{~L}$ acoplada ao misturador elétrico. 
Para definir as dosagens de caulinita e ácido húmico, foram realizados vários testes experimentais em floteste, adicionando progressivamente quantidades conhecidas dos produtos com posterior monitoramento dos parâmetros de controle (turbidez e cor aparente), após agitação de $15 \mathrm{~min}$ a $500 \mathrm{rpm}\left(329 \mathrm{~s}^{-1}\right)$ em misturador elétrico. No decorrer dos ensaios era necessário diminuir a rotação para $300 \mathrm{rpm}\left(153 \mathrm{~s}^{-1}\right)$ devido à redução do nível de água na bombona de $200 \mathrm{~L}$.

\subsection{Caracterização da Água de Estudo}

A caracterização da água de estudo foi realizada por meio de análises de $\mathrm{pH}$, potencial zeta, temperatura, turbidez, cor verdadeira, cor aparente, alcalinidade, condutividade, absorbância 254 nm, carbono orgânico total - COT, dureza, alumínio, chumbo, cádmio, ferro, manganês, mercúrio, coliformes totais e Escherichia coli.

Os procedimentos indicados em APHA, AWWA e WEF (2012) foram utilizados para a quantificação dos parâmetros de qualidade da água.

Os equipamentos utilizados para a caracterização dos parâmetros estão descritos no Apêndice A.

\subsection{Ensaios de Tratabilidade}

Os ensaios foram realizados de acordo com as metodologias de Di Bernardo, Dantas e Voltan (2011) e Edzwald e Haarhoff (2011). O equipamento utilizado foi o Floteste (Flow Text 218), que é composto por três jarros, hastes de agitação, câmara de pressurização, conjunto de dosagem e de coleta, motor com rotação controlada, tacômetro digital com visor que mostra a rotação das paletas e controles para ajuste da rotação (Figura 4). 


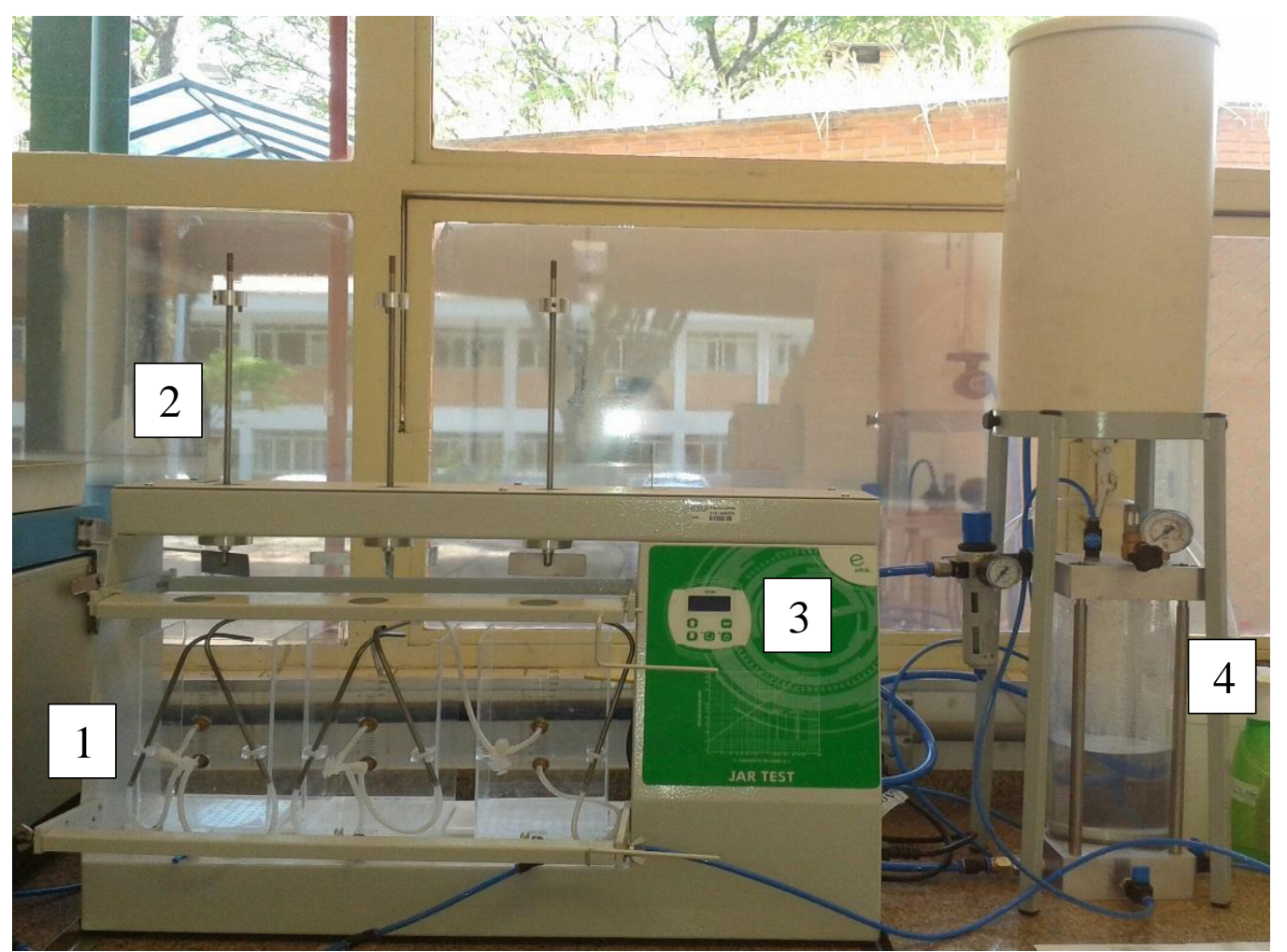

Figura 4: Equipamento de Floteste utilizado na pesquisa. 1- três jarros; 2- hastes de agitação, 3- tacômetro digital com visor que mostra a rotação das paletas e controles para ajuste da rotação e 4- câmara de pressurização.

A princípio foram realizados ensaios de coagulação, floculação e flotação com parâmetros pré-definidos de mistura rápida, mistura lenta e flotação, orientados conforme Edzwald e Haarhoff (2011) variando o pH e a dosagem de coagulante para a construção dos diagramas de coagulação.

O coagulante utilizado no tratamento foi o cloreto de polialumínio - PAC, que possuía as seguintes especificações: densidade de 1,350 g.mL $\mathrm{mL}^{-1}$ e teor de alumínio de $16,36 \%$ na forma de $\mathrm{Al}_{2} \mathrm{O}_{3}$.

Após a elaboração dos diagramas, realizou-se a seleção de um "ponto ótimo" correspondente à dosagem de coagulante e seu respectivo $\mathrm{pH}$ de coagulação. Os diagramas foram construídos para turbidez e cor aparente, por serem estes parâmetros de rápida medição. Posteriormente, ensaios foram efetuados para otimizar os parâmetros de coagulação, floculação e flotação.

Para a etapa de filtração foi empregado o kit de filtros de laboratório de areia - FLAs (Figura 5), segundo recomendações de granulometria (tamanho dos grãos de 0,30 a 0,59 mm e tamanho efetivo de 0,42 mm) e de controle de taxa de filtração indicadas em Di Bernardo, 
Dantas e Voltan (2011). A taxa máxima de filtração adotada foi de $20 \mathrm{~mL} \cdot \mathrm{min}^{-1}\left(\cong 102 \mathrm{~m}^{-3} / \mathrm{m}^{-}\right.$ ${ }^{2} \mathrm{~d}^{-1}$ ), valor próximo à taxa utilizada em filtros em escala plena.

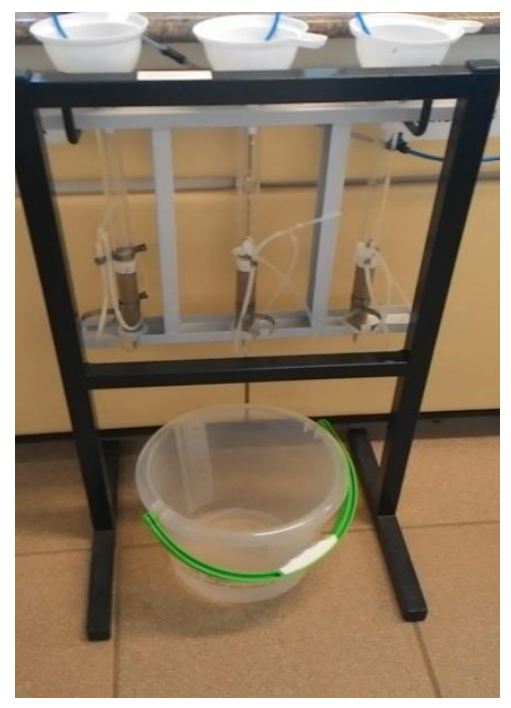

Figura 5: Filtros de laboratório de areia - FLA.

Os FLAs são tubos de acrílico de $19 \mathrm{~mm}$ diâmetro interno por $40 \mathrm{~cm}$ de altura, e 15 cm da coluna são preenchidos com areia. Para obter a granulometria desejada, a areia foi peneirada. O preenchimento dos filtros foi realizado com o auxílio de um cone plástico e uma colher, onde a areia era depositada lentamente, para evitar a formação de bolsões de ar no meio filtrante. Posteriormente, foi realizada a lavagem da areia dos filtros de forma ascendente, por retrolavagem, com o auxílio de uma seringa de plástico, preenchida com 50 $\mathrm{mL}$ de água destilada. A água era injetada pela mangueira acoplada ao filtro e, com isso, ocorria expansão do leito. O procedimento era repetido cinco vezes e no fim, a água de lavagem possuía um aspecto límpido. Finalmente, os filtros eram deixados preenchidos com água, assim, estavam prontos para o ensaio.

O tempo de início de coleta das amostras de água filtrada foi de 20 min após o início da filtração, isto para que ocorresse a substituição completa do volume de água existente nos FLAs no começo do ensaio. O desempenho do tratamento foi avaliado em função da turbidez e da cor aparente.

\subsection{Inóculo de Protozoários}

Inicialmente foram utilizadas duas suspensões de protozoários provenientes da Waterborne (New Orleans - LA, EUA). A cepa de Giardia lamblia com cerca de $1 \times 10^{6}$ 
cistos vivos e armazenados em $4 \mathrm{~mL}$ de PBS e a cepa de Cryptosporidium parvum com cerca de 1 x $10^{6}$ oocistos vivos e armazenados em $4 \mathrm{~mL}$ de PBS (especificações no Apêndice C).

Posteriormente, a suspensão de Giardia lamblia da Waterborne foi substituída pela suspensão purificada no Laboratório de Protozoologia, Instituto de Biologia, da Universidade Estadual de Campinas - UNICAMP contendo 0,2 x $10^{6}$ cistos de Giardia spp. A substituição da suspensão ocorreu devido à formação de aglomerados de cistos que, consequentemente, impossibilitavam a contagem em microscópio.

\subsection{Homogeneização, Desagregação e Contagem das Cepas de Protozoários e Montagem das Lâminas com o Kit Merifluor ${ }^{\circledR}$}

Primeiramente, as suspensões de Giardia spp., Giardia lamblia e Cryptosporidium parvum eram retiradas da geladeira e mantidas em repouso até atingirem a temperatura ambiente.

As lâminas eram nomeadas e dispostas nas proximidades da bancada para receber as alíquotas de protozoários após a homogeneização. As suspensões eram homogeneizadas por 2 min em agitação média do aparelho (Marconi Mod. 162). Após a homogeneização, com a finalidade de desagregar os (oo) cistos, as suspensões eram agitadas vigorosamente com o auxílio de uma pipeta Pasteur de plástico por 20 vezes. Portanto, o procedimento de homogeneização e desagregação era repetido 3 vezes e em seguida, a alíquota desejada de cada suspensão era transferida para três poços das lâminas, sendo que o poço central não recebia as amostras. Como a análise era realizada em triplicata, foram necessárias duas lâminas, sendo utilizados 3 poços.

As suspensões eram tampadas, lacradas com parafilme e retornadas à geladeira. As alíquotas inseridas nos poços deveriam estar secas visualmente para começar a preparação da lâmina então, para isso, aguardava-se um tempo de repouso (ligava-se o ar-condicionado para agilizar o processo).

Enquanto isso, o kit Merifluor ${ }^{\circledR}$ (Figura 6) era retirado da geladeira e os frascos da caixa também eram removidos, para que atingissem a temperatura ambiente. 


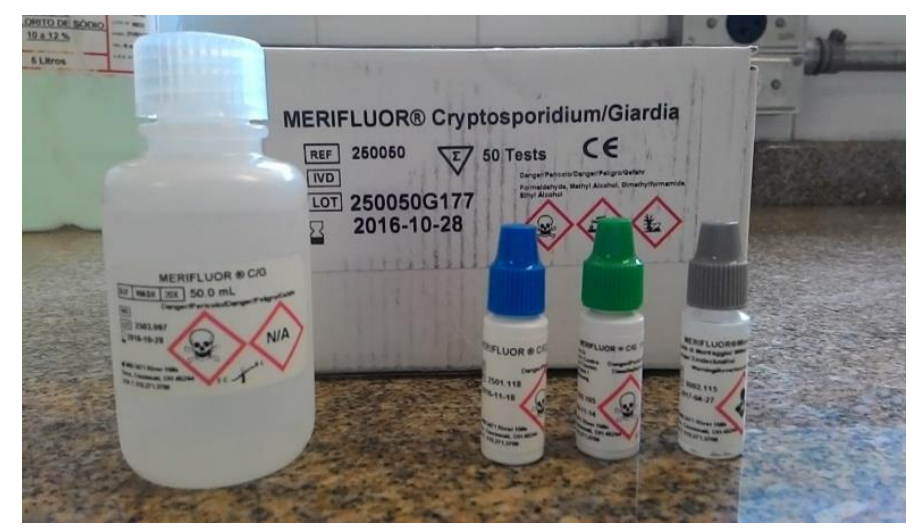

Figura 6: Produtos pertencentes ao Kit Merifluor $^{\circledR}$. Da esquerda para a direita: Solução tampão concentrada 20 x; Reagente de detecção; Contra corante e meio de montagem.

As placas de petri, utilizadas como câmaras escuras e úmidas, eram devidamente preparadas e nomeadas, sendo totalmente recobertas com papel alumínio. Um pequeno pedaço de papel dobrado e umedecido era colocado no seu interior.

Depois que as alíquotas estavam secas, o metanol anidro 99,8\% Sigma-Aldrich $^{\circledR}$ (322415) era adicionado até que se cobrisse a alíquota. No caso o volume necessário deveria ser de $10 \mu \mathrm{L}$ e caso fosse necessário, poderia adicionar mais metanol. Um período de aproximadamente 10 min era aguardado ou até que a alíquota estivesse completamente seca.

As lâminas eram colocadas dentro da câmara escura e na ausência de luz, 1 gota do reagente de detecção do kit Merifluor $^{\circledR}$ (frasco de tampa azul) era adicionado no centro do poço. Imediatamente depois, 1 gota do contra corante do kit Merifluor ${ }^{\circledR}$ (frasco de tampa verde) também era adicionada no centro do poço, repetindo o procedimento para os outros poços e por fim, a câmara escura era tampada e colocada em uma incubadora, onde permanecia por $30 \mathrm{~min}$ a $37^{\circ} \mathrm{C}$.

Durante o tempo de repouso, a solução tampão também presente no kit Merifluor ${ }^{\circledR}$ era diluída de 20 vezes para 1 vez. Antes de diluir, era necessário analisar o volume de solução a ser utilizado na próxima etapa. A diluição era preparada com água Milli-Q.

Depois do período de 30 min e ainda na ausência de luz, cada poço era lavado com 50 $\mu \mathrm{L}$ da solução tampão preparada. O procedimento era repetido mais duas vezes sempre aguardando 1,0 min após efetuar uma lavagem. Portanto, eram necessários $150 \mu \mathrm{L}$ de solução tampão para cada poço.

O excesso das soluções era removido ao redor dos poços com um pequeno pedaço de papel e, então, 1 gota do meio de montagem do kit Merifluor ${ }^{\circledR}$ (frasco de tampa cinza) era adicionada no centro do poço e com cuidado a lamínula era colocada sobre o poço com uma 
inclinação próxima de $45^{\circ}$, para evitar a formação de bolhas. As bordas da lamínula eram seladas com Coverslip Sealante o procedimento era repetido para os demais poços.

A leitura em microscópio deveria ser efetuada até um prazo máximo de sete dias, de acordo com o Método 1623.1 (USEPA, 2012).

A etapa descrita anteriormente era realizada sempre que se desejava determinar a quantidade de protozoários nas suspensões, para obtenção da média para posterior inóculo. Os cálculos referentes à contagem de protozoário eram realizados de acordo com a Equação 1.

Protoz $_{\text {inoculados }}=\frac{\text { Vol }_{\text {inóculo }} \times \text { Média }_{\text {protozoários }}}{\text { Vol }_{\text {contagem }}}$ Equação 1

Em que:

Protoz $_{\text {inoculados }}=$ Número de protozoários inoculados na amostra;

Vol $_{\text {inóculo }}=$ Volume a ser inoculado na amostra $(\mu \mathrm{L}) ;$

Média $a_{\text {protozoários }}=$ Média aritmética de protozoários contados nas três lâminas;

$\mathrm{Vol}_{\text {contagem }}=$ Volume utilizado para efetuar a contagem de $($ oo $)$ cistos no microscópio $(\mu \mathrm{L})$

\subsection{Método De Concentração Dos Protozoários}

A pesquisa testou o método de Floculação em Carbonato de Cálcio - FCCa, desenvolvido por Vesey et al., (1993) e modificado por Feng et al., (2011) e por Giglio (2015) e, novamente, alterado para a amostra de estudo.

Depois da ozonização (apresentada posteriormente no item 4.12), um volume de 2,9 L era coletado da coluna e disposto em um béquer. Todos os utensílios (béqueres, ponteiras, mangueiras e barras magnéticas) que ficavam em contato com a água de estudo, eram previamente enxaguados com Tween 80 a $0,1 \%$.

A amostra era homogeneizada em agitador magnético por $20 \mathrm{~min}$, e ainda sob agitação, $29 \mathrm{~mL}$ de cloreto de cálcio $\left(\mathrm{CaCl}_{2}\right)$ a $1 \mathrm{M}$ era adicionado no béquer e posteriormente $29 \mathrm{~mL}$ de bicarbonato de sódio $\left(\mathrm{NaHCO}_{3}\right)$ a $1 \mathrm{M}$ também era adicionado, e assim, continuava a mistura por mais $10 \mathrm{~min}$.

Ainda em homogeneização, o pH era corrigido para 10, adicionando hidróxido de sódio $(\mathrm{NaOH})$ a $5 \mathrm{M}$ utilizando uma pipeta Pasteur de plástico de $3 \mathrm{~mL}$ e era mantido em agitação por mais 5 min e após este período o agitador era desligado. 
O béquer era tampado com um vidro relógio e padronizou-se deixar as amostras em repouso à temperatura ambiente em overnight. Após o repouso, era nítida a distinção de fases e o sobrenadante era removido por sifonamento até a marcação de aproximadamente $100 \mathrm{~mL}$, previamente identificado no béquer.

A amostra era homogeneizada em agitador magnético por 5 min e após o tempo estipulado, com a amostra ainda sob agitação, $58 \mathrm{~mL}$ de ácido sulfâmico a $10 \%$ era adicionado à amostra e era mantido em agitação por mais 5 min.

Depois da homogeneização, a amostra era transferida para os tubos de centrífuga. Como havia aproximadamente $100 \mathrm{~mL}$ de amostra, $58 \mathrm{ml}$ de ácido sulfâmico e era preciso efetuar lavagens, utilizou-se 4 tubos de centrífuga de $50 \mathrm{~mL}$ para cada amostra. Com o uso de pipetas automáticas de $10 \mathrm{~mL}$, a amostra era coletada ainda em agitação e transferida para os respectivos tubos de centrífuga. Procurava-se dividir as amostras igualmente. O béquer era enxaguado com Tween 80 a 0,1\%, duas vezes de $20 \mathrm{~mL}$ em cada lavagem, e a partir daí, era efetuada a transferência da amostra para os tubos de centrífuga.

As amostras eram centrifugadas a $1500 \mathrm{~g}$ por $20 \mathrm{~min}$. Após a centrifugação o sobrenadante era descartado até a marcação de $1 \mathrm{~mL}$ de todos os tubos e os pellets resultantes eram transferidos para um único tubo, com a realização de enxagues com Tween 80 a $0,1 \%$.

Depois da transferência da amostra para um único tubo, as amostras eram centrifugadas novamente nas mesmas condições anteriores. Finalizada esta etapa, o sobrenadante era removido até a marcação de $5 \mathrm{~mL}$ do tubo e o $\mathrm{pH}$ era medido. Caso não estivesse neutro, o pH era corrigido, adicionando-se Phosphate Buffered Saline - PBS, pH 7.4 da Sigma-Aldrich ${ }^{\circledR}$ (P3813) e era realizada a última centrifugação das amostras.

Por fim, o sobrenadante era descartado até a marcação de $1 \mathrm{~mL}$, no caso da etapa 1 (descrita posteriormente no item 4.12.1.1), o pellet resultante era homogeneizado, e posteriormente, 3 alíquotas de $50 \mu \mathrm{L}$ do pellet era disposto em cada poço da lâmina, pois o ensaio era realizado em triplicata (visando reduzir o fator de multiplicação). Os cálculos eram feitos individualmente, ou seja, primeiro calculava-se a recuperação de um tipo de protozoário, e em seguida, do outro. A Equação 2 foi utilizada para contabilizar os organismos visualizados.

$R=\frac{(P 1+P 2+P 3) \times F M}{\text { Protoz }_{\text {inoculados }}} \times 100 \%$

Equação 2

Em que: 
$\mathrm{R}=$ Porcentagem de recuperação do método $(\%)$;

$\mathrm{C} 1$ = Contagem de (oo) cistos do primeiro poço da lâmina;

C2 = Contagem de (oo) cistos do segundo poço da lâmina;

C3 = Contagem de (oo) cistos do terceiro poço da lâmina;

FM = Fator de multiplicação;

Protoz $_{\text {inoculados }}=$ Número de protozoários inoculados na amostra.

No caso da etapa 2 (item 4.12.1.2), o sobrenadante era descartado até a marcação de 5 $\mathrm{mL}$ e o pellet era encaminhado para a etapa de separação imunomagnética, descrita a seguir.

\subsection{Purificação das Amostras por Separação Imunomagnética (IMS)}

Primeiramente, era utilizada uma pipeta Pasteur de plástico para aspirar e expulsar o sobrenadante de $5 \mathrm{~mL}$, obtido após procedimento do Item 4.6, visando homogeneização.

O procedimento seguiu as instruções do kit Dynabeads ${ }^{\circledR}$ Life Technologies $^{\mathrm{TM}}$ (Figura 7), descrito a seguir.
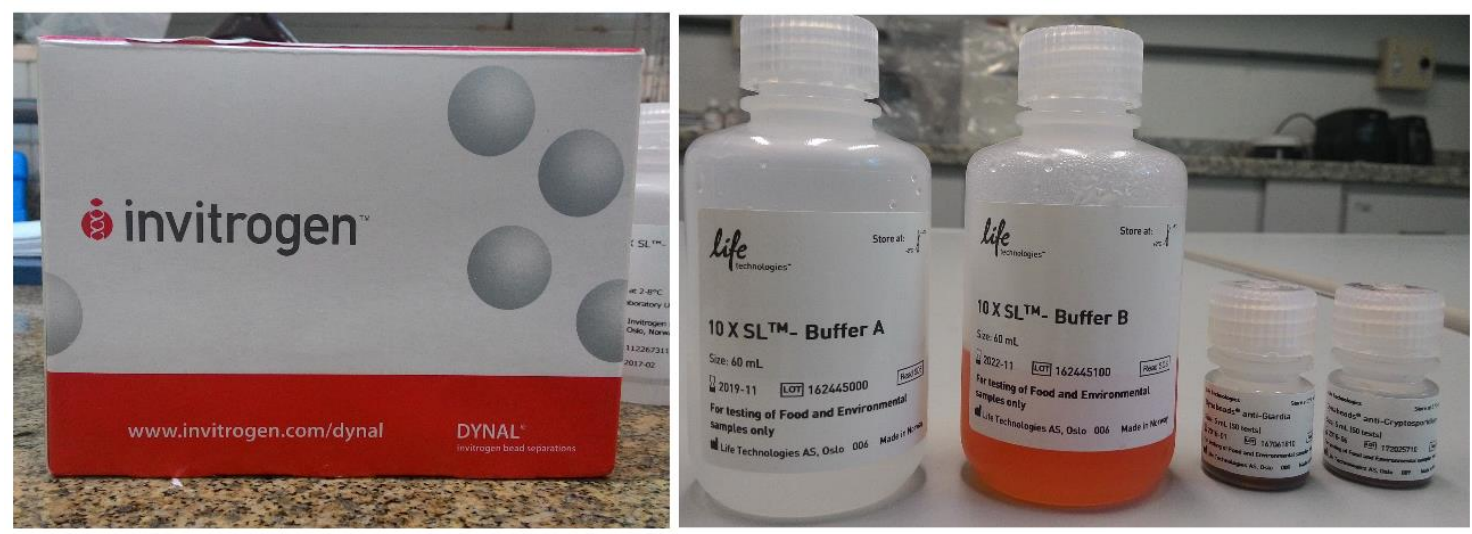

Figura 7: Foto do kit Dynabeads ${ }^{\circledR}$ Life Technologies ${ }^{\mathrm{TM}}$. Produtos pertencentes ao kit. Da esquerda para a direita: Solução tampão SL-A 10X; Solução tampão SL-B 10X; Dynabeads ${ }^{\circledR}$ anti-Giardia e Dynabeads ${ }^{\circledR}$ anti-Cryptosporidium.

Em um tubo de lado plano - TLP (Dynal L10 tubes, Cat. no. 740.03), era adicionado 5 $\mathrm{mL}$ da amostra, juntamente com as 2 lavagens de 2,5 $\mathrm{mL}$ de Tween 80 a 0,01\%, e em seguida adicionava-se $1 \mathrm{~mL}$ de solução tampão SL-A $10 \mathrm{X}$ e $1 \mathrm{~mL}$ de solução tampão SL-B 10X, ambos provenientes no kit. Em seguida, era realizada a adição dos anticorpos conjugados às 
microesferas magnéticas, específicos para os antígenos das paredes dos cistos de Giardia spp.

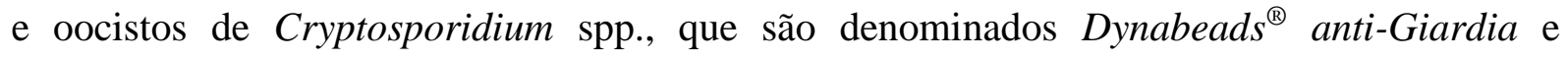
Dynabeads ${ }^{\circledR}$ anti-Cryptosporidium. Estes complexos eram homogeneizados em vortéx antes de serem adicionados ao TLP, um por vez, com cuidado, para evitar a adesão do material na tampa dos frascos. Assim, imediatamente após cada homogeneização, uma alíquota de 100 $\mu \mathrm{L}$ de cada frasco era transferida para o TLP.

Posteriormente, todo o volume contido no TLP era misturado. Para isso, o tubo era acoplado a um mixer rotatório (Invitrogen Dynabeads ${ }^{\circledR}$ Sample Mixer) e era agitado a $18 \mathrm{rpm}$ por no mínimo uma hora à temperatura ambiente.

Após o tempo de agitação, o tubo era retirado do mixer rotatório e colocado no primeiro concentrador de partículas magnéticas (Invitrogen Dynal MPC-1), de forma que o lado plano do tubo era mantido em contato com a parte que contém o ímã e a tampa era voltada para cima. Movimentos manuais eram realizados em um ângulo de $90^{\circ}$ inclinando a extremidade da tampa do tubo para cima e para baixo, sendo que o lado plano do ímã permanecia em contato com o líquido tanto na posição horizontal como na vertical.

Estes movimentos eram realizados ininterruptamente por 2 min, sendo um movimento completo por segundo. Sem remover o TLP do MPC-1, o conjunto era retornado à posição vertical, com a tampa voltada para cima, que era removida para o descarte do sobrenadante, e o descarte da amostra era realizado com o lado plano do tubo voltado para cima.

Antes de iniciar a próxima etapa, o micro tubo de $1,5 \mathrm{~mL}$ da amostra era enxaguado com Tween 80 a $0,1 \%$ e colocado no segundo concentrador de partículas (Invitrogen Dynal MPC-S) sem a fita magnética.

Então, após o descarte do sobrenadante do TLP, este era removido do MPC-1 e com o auxílio de uma pipeta automática de $1 \mathrm{~mL}, 0,5 \mathrm{~mL}$ da solução tampão SL-A 10X (o tampão presente no kit, que era diluído em 10 vezes) era adicionada somente na parte plana do TLP, para evitar atingir os resíduos aderidos nas outras paredes do tubo. A amostra era suavemente misturada com o tampão diluído, com movimentos na horizontal, com cautela, para que a amostra não ultrapassasse o limite do lado plano do tubo.

Quando a solução adquiria um aspecto homogêneo, com o uso de uma pipeta Pasteur de vidro de $230 \mathrm{~mm}$, a amostra era transferida para um micro tubo de centrífuga de 1,5 mL, que já estava conectado no MPC-S, sem a fita magnética. Em seguida, era realizado mais um enxágue com o tampão SL-A 10X e o procedimento era repetido.

Com o micro tubo acoplado ao $2^{\circ}$ concentrador de partículas, a fita magnética removível era inserida e os movimentos manuais eram iniciados. No MPC-S, o movimento 
era feito em um ângulo de $180^{\circ}$ durante $1 \mathrm{~min}$, e evitando que a tampa do micro tubo ficasse direcionada para baixo.

No final desta etapa, notava-se que as partículas ficavam com uma nítida mancha marrom na parte de trás do tubo, que ficava em contado com o ímã da fita magnética. Assim, o sobrenadante era aspirado do micro tubo e descartado, com o tubo ainda mantido no MPC-S com a fita. A aspiração era realizada com uma pipeta Pasteur de vidro de $230 \mathrm{~mm}$.

Posteriormente, o micro tubo contendo a amostra com os Dynabeads era removido do MPC-S e em seguida, a fita magnética também era retirada. Então, finalizada a etapa de concentração, era necessário separar a amostra das microesferas, procedimento este que era caracterizado por dissociação, podendo ser de duas maneiras: ácida ou térmica. Para esta pesquisa, foi utilizada somente a dissociação ácida, que será descrita a seguir.

$\mathrm{Na}$ etapa de dissociação ácida, a fita magnética era removida do MPC-S e, posteriormente, o micro tubo de centrífuga contendo a amostra era enxaguado com um volume de com $50 \mu \mathrm{L}$ de uma solução de ácido clorídrico $0,1 \mathrm{~N}$, que era direcionado diretamente na amostra em questão. O tubo era levado ao vórtex, por um período de 1 min, para homogeneização da amostra, que era realizada com cautela, para evitar que as partículas se aderissem às paredes ou na tampa do tubo. Toda a amostra deveria ficar na base do tubo.

Após a homogeneização, o tubo era colocado de volta no MPC-S, sem a fita magnética, onde era mantido em repouso, por um período de $10 \mathrm{~min}$, no máximo. Depois deste tempo, a amostra apresentava nítida distinção entre as fases, e era novamente homogeneizada no aparelho de vórtex e recolocada no MPC-S, agora com a fita magnética. Então, certificava-se de que o material estivesse na base do tubo. Este era, então, deixado em repouso por um período mínimo de 10 segundos.

$\mathrm{Na}$ lateral do tubo, observava-se que era formada uma mancha marrom. O material sobrenadante $(50 \mu \mathrm{L})$ era coletado por uma micropipeta automática, com sua ponteira previamente enxaguada com solução de eluição e levado ao poço da lâmina do kit Merifluor $^{\circledR}$.

Ao poço da lâmina de microscopia era adicionado $5 \mu \mathrm{L}$ de hidróxido de sódio padrão 1 $\mathrm{N}$, antes da adição do material sobrenadante da etapa anterior, para neutralizar os $50 \mu \mathrm{L}$ de ácido clorídrico $0,1 \mathrm{~N}$.

O procedimento de dissociação ácida era repetido por mais duas vezes para avaliar a recuperação do método. Assim, o procedimento era repetido até a terceira dissociação ácida. Realizava-se em seguida o procedimento de preparo da lâmina para o exame de microscopia de imunofluorescência (Item 4.8). 
Os cálculos eram feitos individualmente, ou seja, primeiro calculava-se a recuperação de um tipo de protozoário, e em seguida, do outro. A Equação 3 foi utilizada para contabilizar os organismos visualizados.

$R=\frac{(C 1+C 2+C 3) \times F M}{\text { Protoz }_{\text {inoculados }}} \times 100 \%$ Equação 3

Em que:

$\mathrm{R}=$ Porcentagem de recuperação do método $(\%)$;

$\mathrm{C} 1$ = Contagem de (oo) cistos na $1^{\mathrm{a}}$ dissociação ácida;

C2 = Contagem de (oo) cistos na $2^{\mathrm{a}}$ dissociação ácida;

C3 = Contagem de (oo) cistos na $3^{\mathrm{a}}$ dissociação ácida;

$\mathrm{FM}=$ Fator de multiplicação;

Protozinoculados $=$ Número de protozoários inoculados na amostra .

Depois da realização do cálculo de recuperação, cada método era avaliado de acordo com o controle de qualidade do Método 1623.1, em que a média de recuperação deve estar entre $8-100 \%$ para cistos de Giardia spp. e $32-100 \%$ para oocistos de Cryptosporidium spp., conforme será descrito no item 4.10 .

\subsection{Procedimento de Preparo das Lâminas com o Kit Merifluor ${ }^{\circledR}$ e Aplicação do DAPI e IP}

As lâminas eram nomeadas e dispostas nas proximidades da bancada para receber as alíquotas de protozoários após a homogeneização. As suspensões eram homogeneizadas por 2 min em agitação média do aparelho (Marconi Mod. 162). Após a homogeneização, a alíquota desejada de cada suspensão era transferida para 3 poços das lâminas, sendo que o poço central não recebia as amostras. Como a análise era realizada em triplicata, foram necessárias 2 lâminas, sendo utilizados 3 poços.

As suspensões eram tampadas, lacradas com parafilme e retornadas à geladeira. As alíquotas inseridas nos poços deveriam estar secas visualmente para começar a preparação da lâmina, então para isso, aguardava-se um tempo de repouso (aconselhava-se ligar o arcondicionado, para agilizar a secagem dos poços). 
Esta etapa descrita anteriormente era realizada sempre que se desejava determinar a concentração de protozoários nas suspensões, para obtenção da média para posterior inóculo. Para as amostras obtidas após o método de concentração (com e sem IMS), as lâminas deviam ser deixadas na bancada para receber a alíquota final, que era de $50 \mu \mathrm{L}$ e efetuada em triplicata, ou seja, no final eram utilizados $150 \mu \mathrm{L}$ dispostos em 3 poços para cada ensaio.

Após o procedimento de lavagem das lâminas, conforme procedimento indicado no kit Merifluor, descrito no item 4.5, o excesso das soluções era removido ao redor dos poços com um pequeno pedaço de papel, e então, ainda na ausência de luz, 3 gotas do Fluoroshield ${ }^{\mathrm{TM}}$ with DAPI (Sigma - F6057) eram adicionadas em cada poço e aguardava-se um período de 15 min em temperatura ambiente. Decorrido o tempo de contato, era necessário efetuar 3 lavagens de $50 \mu \mathrm{L}$ em cada poço com a solução Hanks' Balanced Salt Solution - HBSS, da Sigma-Aldrich $^{\circledR}$ (H9269). Depois da lavagem, $50 \mu \mathrm{L}$ do Iodeto de Propídeo - IP, da SigmaAldrich $^{\circledR}$ (P4170) era adicionado em cada poço e aguardava-se 5 min. A mesma lavagem realizada anteriormente deveria ser repetida para o IP. E por fim, uma lavagem de $50 \mu \mathrm{L}$ de água Milli-Q era realizada em cada poço para evitar a formação de cristais na lâmina (destacase que a otimização do uso do IP está descrita no item 4.11.2.8).

Para encerrar a preparação da lâmina (conforme item 4.5), 1 gota do meio de montagem do kit Merifluor ${ }^{\circledR}$ (frasco de tampa cinza) era adicionado no centro do poço e com cuidado a lamínula era colocada sobre o poço com uma inclinação próxima de $45^{\circ}$, para evitar a formação de bolhas. As bordas da lamínula eram seladas com o selante Coverslip Sealant, e o procedimento era repetido para os demais poços. As lâminas eram encaminhadas para a leitura em microscópio.

\subsection{Identificação de Protozoários Utilizando Microscopia de Imunofluorescência}

As amostras eram analisadas em microscópio de imunofluorescência, utilizando o equipamento Olympus ${ }^{\circledR}$ BX51, sob aumento de $400 \mathrm{x}$, onde eram realizadas a identificação dos (oo) cistos através da reação de imunofluorescência direta (RID), a contagem de protozoários, as análises confirmatórias com DAPI e a estimativa da viabilidade por IP.

A identificação, as análises confirmatórias e a contagem dos protozoários eram realizadas de maneira semelhante ao procedimento utilizado para contagem de protozoários para os inóculos (Item 4.5). A diferença entre as análises é a inclusão do DAPI e IP. Assim, 
além da análise FITC, realizava-se a análise microscópica DAPI para confirmação de aspectos morfológicos e WG para a visualização do IP.

De acordo com USEPA (2012), para a RID, era avaliada a presença de estruturas esféricas de 4 a $6 \mu \mathrm{m}$ para oocisto e ovóides de 8 a $18 \mu \mathrm{m}$ de comprimento por 5 a $15 \mu \mathrm{m}$ de largura para cisto. Aliado a isto, a parede do (oo) cisto deveria apresentar fluorescência verdemaçã brilhante, sem poros ou apêndices e apresentando sutura, para oocistos, ou axonema, para cistos, visível, exibindo forte fluorescência.

Para os testes com DAPI, o (oo) cisto deveria apresentar uma ou mais das seguintes características: i) dois a quatro núcleos azul-claros; ii) intensa coloração azul interna; e iii) ligeira coloração azul interna (sem núcleos distintos) e uma borda verde.

As alternativas (i) e (ii) são registradas como DAPI positivo (+) e (iii) como DAPI negativo (-). Para os testes com IP, os (oo) cistos identificados por RID e DAPI eram diferenciados em: a) IP negativo (-): não penetração do reagente iodeto de propídio no (oo) cisto - viável; e b) IP positivo (+): penetração do reagente no (oo) cisto não viável.

Após a identificação e contagem, o número de (oo) cistos era calculado, a fim de estimar a porcentagem de recuperação do protocolo avaliado, de acordo com o Método 1623.1, conforme Equação 2 do item 4.6.

\subsection{Controle da Qualidade Analítica do Método de Concentração (FCCa) em Amostras de Água.}

Os ensaios de controle de qualidade foram realizados de duas formas: i) com suspensão de cistos de Giardia spp. purificados na UNICAMP e com suspensão comercial de oocistos de Cryptosporidium parvum da empresa Waterborne; e ii) com os inóculos EasySeed $^{\circledR}$ com características apresentadas no Apêndice C.

O número de (oo) cistos encontrados era comparado com o número de (oo) cistos inoculados, de acordo com a Equação 4. A porcentagem de recuperação era calculada para estimar o desempenho do método avaliado, neste caso, FCCa com e sem IMS.

$\%$ Recuperação $=\frac{\text { № (oo) } \text { cistos encontrados } / L}{N^{\circ}(\text { oo }) \text { cistos inoculados } / L} \times 100$

Equação 4 
A média da porcentagem de recuperação e o desvio padrão relativo à média (coeficiente de variação), foram avaliados através de quatro ensaios em conjunto com o branco, conforme estipula o Método 1623.1 (USEPA, 2012).

\subsubsection{Controle da Qualidade Analítica do Método de FCCa Utilizando Suspensões de (oo) cistos.}

Os primeiros ensaios foram realizados com algumas alterações em relação ao Método 1623.1 (USEPA, 2012), visando treinamento; portanto utilizaram-se suspensões de cistos de Giardia spp. e de oocistos de Cryptosporidium parvum, inoculando uma quantidade média de (oo) cistos. Inicialmente, foi realizada a determinação da concentração de protozoários nas suspensões para posterior inóculo, atividade que foi realizada com $5 \mu \mathrm{L}$ da suspensão de Giardia spp. e $50 \mu \mathrm{L}$ de Cryptosporidium parvum, em triplicata. Depois de encontrado o valor necessário para a inoculação, que foi estipulado em cerca de 500 (oo) cistos. $\mathrm{L}^{-1}$, o inóculo foi realizado em $1 \mathrm{~L}$ de água filtrada (obtida utilizando o floteste com kit de filtros), para posterior processamento utilizando o Método de FCCa, neste caso, sem o IMS.

\subsubsection{Controle da Qualidade Analítica do Método de FCCa utilizando o EasySeed ${ }^{\circledR}$}

A etapa foi realizada com o inóculo de 100 cistos e 100 oocistos, presentes na suspensão comercial EasySeed ${ }^{\circledR}$ (características no Apêndice D), em 1 L de água filtrada.

A inoculação foi efetuada com base nas instruções contidas no produto comercial. Inicialmente, adicionava-se $2 \mathrm{~mL}$ de solução de Tween 20 a $0,05 \%$ ao tubo contendo a solução do inóculo. No aparelho de vórtex (Marconi Mod. 162), agitava-se o tubo por $20 \mathrm{~s} \mathrm{e}$ despejava-se a solução em um béquer de $1 \mathrm{~L}$, que continha a água filtrada. Depois, era adicionado $3 \mathrm{~mL}$ de água Milli-Q no tubo, seguida de uma nova agitação no vórtex por $20 \mathrm{~s}$, sendo esta lavagem disposta no béquer. Posteriormente, repetia-se a lavagem mais uma vez, com 3 mL de água Milli-Q.

As etapas de concentração, purificação (nos ensaios que se utilizou o IMS), preparo da lâmina e, finalmente, leitura e contagem dos organismos encontrados foram realizadas na matriz (água filtrada - obtida utilizando o floteste com kit de filtros), isto considerando quatro ensaios e um branco, conforme estabelecido pela USEPA (2012). 


\subsection{Teste Visando Estimar a Viabilidade dos (oo) cistos}

Para estimar a viabilidade dos protozoários na perspectiva da engenharia prática, dois corantes vitais foram estudados: i) o azul de tripano; e ii) o iodeto de propídio em conjunto com DAPI e anticorpos monoclonais FITC.

\subsubsection{Estimativa da Viabilidade utilizando o Azul de Tripano}

Sete métodos foram realizados para estimar a viabilidade dos organismos alvo, conforme será descrito a seguir. A solução de azul de tripano da Sigma-Aldrich ${ }^{\circledR}$ (T8154), com concentração de $0,4 \%$, foi empregada nos testes.

Neste teste utilizando o azul de tripano, uma suspensão de células é simplesmente misturada com corante e, em seguida, examinada visualmente para determinar se as células penetram ou excluem o corante. No protocolo apresentado aqui uma célula viável apresenta um citoplasma claro, ao passo que, uma célula não viável apresenta um citoplasma azul.

O protocolo descrito na bula do azul de tripano foi utilizado como referência, conduto, algumas adaptações aconteceram. Os cálculos efetuados para se obter a porcentagem de organismos viáveis consideraram a Equação 5.

Células viáveis $(\%)=\frac{\text { № total de células viáveis por } m L \text { de alíquota }}{N^{\circ} \text { total de células por } m L \text { de alíquota }} \times 100$ Equação 5

A contagem das células não coradas (viáveis) e as coradas (não viáveis) foi realizada separadamente na lâmina. Para calcular o número total de células viáveis por $\mathrm{mL}$ de alíquota, multiplicou-se o número total de células viáveis por dois (o fator de diluição para o azul de tripano). Para calcular o número total de células por $\mathrm{mL}$ de alíquota, adiciona-se o número total de células viáveis e não viáveis e multiplicava-se por 2.

\subsubsection{Método 1 AT - Incubação da Suspensão Giardia spp. em Azul de Tripano em Tubo PCR}

A homogeneização da suspensão de Giardia spp. foi efetuada. O procedimento considerou agitação da suspensão em vortéx por 2 min (agitação média) e, depois, com o 
auxílio de uma pipeta Pasteur de plástico (previamente enxaguada com Tween 80 0,1\%), agitou-se por 20 vezes. O procedimento foi repetido três vezes.

Em seguida, $50 \mu \mathrm{L}$ da suspensão homogeneizada e $50 \mu \mathrm{L}$ do azul de tripano foram adicionados ao tubo PCR com capacidade de 1,5 mL, sendo incubado por $3 \mathrm{~min}$. Leves inclinações no tubo foram realizadas juntamente com batidinhas com a ponta do tubo na bancada visando uma mistura completa. Posteriormente, uma alíquota de $10 \mu \mathrm{L}$ da suspensão contida no tubo PCR foi retirada e disposta em uma lâmina lisa, seguido da colocação da lamínula.

A lâmina estava pronta para ser encaminhada para a leitura em microscópio, que foi realizada no campo claro com aumento de $400 \mathrm{x}$.

\subsubsection{Método 2 AT - Substituição da Suspensão de Giardia, Aumento do Tempo de Homogeneização, Volume de Inóculo Menor e Aplicação do Corante direto na Lâmina Lisa}

Como os resultados obtidos no Método 1 AT não foram satisfatórios, algumas etapas do procedimento foram alteradas. Portanto, a suspensão de Giardia lamblia da empresa Waterborne (Apêndice C) foi utilizada, porque a suspensão indicada no item 4.11.1.1 era antiga (aproximadamente 6 meses de preparo).

No Método 2 AT, o tempo de homogeneização da suspensão no vortéx foi superior, sendo adotado 4 min (o dobro do tempo utilizado no primeiro método - item 4.11.1.1) e com o auxílio de uma pipeta Pasteur de plástico, a suspensão foi agitada por 20 vezes. A homogeneização foi repetida três vezes.

Em seguida, $5 \mu \mathrm{L}$ da suspensão homogeneizada e $5 \mu \mathrm{L}$ do azul de tripano foram dispostos diretamente na lâmina lisa e a mistura foi incubada por $3 \mathrm{~min}$, sendo homogeneizada com a própria ponteira. Depois de decorrido o tempo, a lamínula foi colocada e a leitura em campo claro foi realizada com aumento de 400 x. O ensaio foi realizado, em condições iguais, quatro vezes.

\subsubsection{Método 3 AT - Centrifugação da Suspensão de Giardia Lamblia e Repetição do Procedimento Anterior}


Os resultados do Método 2 AT não foram bem-sucedidos, portanto, algumas alterações foram realizadas.

A mesma suspensão do Método 2 AT foi utilizada, contudo, foi centrifugada para aumentar a concentração de cistos, isto com rotação de 1500 g por 20 min. Depois, o sobrenadante foi descartado até a marcação de 1,0 mL com adição de 1,0 mL de Phosphate Buffered Saline - PBS, pH 7.4 da Sigma-Aldrich ${ }^{\circledR}$ (volume final de $2 \mathrm{~mL}$ ). $\quad$ Os procedimentos de homogeneização, incubação e leitura foram análogos ao Método 2 AT (item 4.11.1.2).

\subsubsection{Método 4 AT - Centrifugação da Suspensão de Giardia Lamblia, Aumento do Inóculo e Incubação em Eppendorff}

Para verificar a presença de cistos de Giardia na suspensão utilizada, visto que não foi encontrado nenhum organismo nos ensaios anteriores, um procedimento de desagregação dos cistos foi realizado e, depois, as lâminas foram preparadas seguindo o procedimento do kit Merifluor ${ }^{\circledR}$ para realizar a contagem em microscopia.

A suspensão de Giardia lamblia foi centrifugada a 1500 g por 10 min. Posteriormente, descartou-se 1,0 $\mathrm{mL}$ de sobrenadante; portanto, o volume final era de 1,0 mL. A homogeneização foi realizada por 2 min em vortéx, posteriormente, agitada 20 vezes com o auxílio de uma pipeta Pasteur de plástico e o procedimento foi repetido três vezes. Uma alíquota de $5 \mu \mathrm{L}$ da suspensão foi colocada em três poços e as lâminas foram preparadas.

Portanto, com a suspensão mais concentrada, esperava-se que a quantidade de cistos fosse maior, então o procedimento para o corante azul de tripano foi realizado novamente.

Considerando que a suspensão de Giardia lamblia apresentava agregados de cistos, o procedimento para ruptura envolveu a homogeneização da suspensão por 2 min, utilizando o vortéx, em agitação média e, depois, misturou-se por 20 vezes com auxílio de uma pipeta Pasteur de plástico. O procedimento era repetido mais duas vezes.

$\mathrm{O}$ volume a ser incubado foi alterado utilizando-se $10 \mu \mathrm{L}$ de suspensão e $10 \mu \mathrm{L}$ de azul de tripano e a mistura foi colocada em um Eppendorff de 2,0 mL, por $3 \mathrm{~min}$. Uma alíquota de $10 \mu \mathrm{L}$ foi retirada e colocada na lâmina lisa para posterior leitura em campo claro com aumento de $400 \mathrm{x}$.

\subsubsection{Método 5 AT - Alteração do Volume Incubado e Utilização de Toda a Alíquota Contida no Eppendorff}


O procedimento do Método 4 AT foi repetido com alteração do volume incubado, visando colocar todo o conteúdo do tubo Eppendorff na lâmina para realizar a leitura, a fim de evitar perdas. O volume incubado foi de $5 \mu \mathrm{L}$ da suspensão e $5 \mu \mathrm{L}$ do azul de tripano no Eppendorff de 2,0 mL por $3 \mathrm{~min}$. A alíquota total de $10 \mu \mathrm{L}$ foi disposta na lâmina lisa e encaminhada para a leitura em campo claro com aumento de $400 \mathrm{x}$.

\subsubsection{Método 6 AT - Aumento do Inóculo e Avaliação dos Resultados}

Devido aos resultados insatisfatórios dos métodos anteriores, mesmo com as alterações realizadas, o uso do azul de tripano foi avaliado qualitativamente, considerando unicamente a dificuldade ou facilidade de leitura no campo claro para os organismos-alvo.

O procedimento de desagregação dos cistos foi análogo ao indicado no item 4.5. No Método 6 AT, a incubação foi realizada com $10 \mu \mathrm{L}$ de suspensão e $10 \mu \mathrm{L}$ de azul de tripano no Eppendorff de 2,0 $\mathrm{mL}$ por $3 \mathrm{~min}$. Uma alíquota de $10 \mu \mathrm{L}$ da mistura foi retirada e colocada na lâmina lisa, seguido da lamínula e a leitura em campo claro com aumento de $400 \mathrm{x}$.

O ensaio descrito foi realizado cinco vezes para avaliação de cada parasito, Giardia e Cryptosporidium, totalizando dez leituras. As lâminas foram preparadas individualmente e encaminhadas para a leitura, destacando que não era possível preparar todas as lâminas de uma única vez, considerando que a lâmina deveria ser lida logo em seguida da preparação para evitar longas exposições ao corante e obter resultados falso-positivos.

\subsubsection{Método 7 AT - Substituição da Suspensão de Giardia Lamblia, Alteração do volume de Inóculo e Incubação Direto na} Lâmina

Ao finalizar o Método 6 AT, um último método foi testado, em triplicata, e analisado em função da qualidade de leitura dos cistos na lâmina. As suspensões de Giardia spp. da UNICAMP e de Cryptosporidium parvum da Waterborne foram utilizadas.

O procedimento de homogeneização das suspensões foi de 2 min no vortéx e agitadas por 20 vezes com o auxílio de uma pipeta Pasteur de plástico. O processo foi repetido três vezes. Uma alíquota de $5 \mu \mathrm{L}$ da suspensão e outra de $5 \mu \mathrm{L}$ do azul de tripano foram incubados 
diretamente na lâmina lisa, sendo homogeneizados por 3 min com a própria ponteira (o ensaio foi realizado separadamente para cada protozoário). A lamínula foi colocada cuidadosamente para não formar bolhas e, em seguida, foi realizada a leitura em campo claro com aumento de $400 \mathrm{x}$.

\subsubsection{Estimativa da Viabilidade Utilizando o Iodeto de Propídio - IP}

Os corantes fluorogênicos vitais IP e DAPI são baseados na permeabilidade da membrana, que permite ou não a inclusão dos corantes. O IP é um corante de exclusão, cora as células mortas ou muito danificadas e o DAPI, por sua vez, é um corante de inclusão para células com a membrana intacta, porém, estes corantes se ligam ao material nuclear e esta ligação ocorre mesmo que a célula esteja morta (SANTOS, 2007).

O método foi realizado tomando como base os protocolos indicados em Campbell et al., (1992), Grimason et al., (1994), Medema et al., (1997), Robertson et al., (2000), Betancourt et al., (2003), Olvera et al., (2008), Medeiros (2010). Para avaliar o uso do IP juntamente com o DAPI, alguns testes foram realizados, visando obter os parâmetros necessários ao ensaio e os cálculos para obter a eficiência do método foram efetuados de acordo com a Equação 6 (SANTOS, 2007).

$Y=\frac{R}{I} \times 100$ Equação 6

Em que:

$\mathrm{Y}=$ Eficiência de recuperação;

$\mathrm{R}=$ Número de cistos e oocistos recuperados;

I = Número de cistos e oocistos inoculados.

Os métodos e as adaptações são descritos a seguir.

\subsubsection{Método 1 IP - Teste Seguindo a Metodologia de Campbell et al., (1992)}

Após a desagregação e homogeneização dos (oo) cistos pelo procedimento descrito no item 4.5 foram incubados $50 \mu \mathrm{L}$ da suspensão de Giardia lamblia, em $50 \mu \mathrm{L}$ de HBSS, com 
$10 \mu \mathrm{L}$ da solução preparada de DAPI e mais $10 \mu \mathrm{L}$ de IP em um Eppendorff de 2,0 mL a $37^{\circ} \mathrm{C}$ por $10 \mathrm{~min}$. Após o tempo de incubação, os corantes foram lavados com $150 \mu \mathrm{L}$ de HBSS; a amostra foi centrifugada a $2000 \mathrm{~g}$ por $15 \mathrm{~min}$ e o sobrenadante foi descartado (150 $\mu \mathrm{L}$ ). O procedimento de lavagem foi repetido e, dessa vez, foram descartados $200 \mu \mathrm{L}$ de sobrenadante (toda a solução de HBSS colocada foi, então, retirada). Após a segunda centrifugação, o sedimento foi homogeneizado por 2 min no vortéx. Uma alíquota de $10 \mu \mathrm{L}$ da mistura foi colocada na lâmina lisa para a realização da leitura em Isotiocianato de fluoresceína - FITC com aumento de 400 x.

\subsubsection{Método 2 IP - Ensaio Realizado Conforme o Método de Dowd e Pillai (1997)}

O procedimento foi repetido, mas, neste caso, utilizando o kit Merifluor $^{\circledR}$, segundo recomendado por Dowd e Pillai (1997). O mesmo protocolo de desagregação e homogeneização dos (oo) cistos indicados no item 4.5 foi empregado.

Depois foram adicionados ao Eppendorff de 2,0 mL, $50 \mu \mathrm{L}$ da suspensão de Giardia lamblia com $10 \mu \mathrm{L}$ de DAPI e $10 \mu \mathrm{L}$ de IP, desta vez sem o HBSS (visto que a suspensão já está imersa em Phosphate Buffered Saline - PBS) a $37^{\circ} \mathrm{C}$ no escuro (o Eppendorff foi coberto com papel alumínio) e por um período de $2 \mathrm{~h}$.

Decorrido o tempo de incubação, o Eppendorff foi retirado da incubadora e foram realizadas duas lavagens. Na primeira lavagem, foram utilizados $150 \mu \mathrm{L}$ de $\mathrm{HBSS}(\mathrm{pH}$ 7,62) e a amostra foi centrifugada a $2000 \mathrm{~g}$ por $15 \mathrm{~min}$. O sobrenadante foi descartado $(150 \mu \mathrm{L})$ e a segunda lavagem foi realizada logo em seguida com o mesmo procedimento. A alíquota resultante após a segunda lavagem era de $70 \mu \mathrm{L}$, que foram homogeneizados por 2 min no vortéx e colocados na lâmina contida no kit Merifluor ${ }^{\circledR}$.

A lâmina foi preparada seguindo o procedimento de uso do kit Merifluor ${ }^{\circledR}$. Finalmente, a leitura foi realizada, utilizando FITC para visualizar os cistos, DAPI para a leitura do DAPI, utilizado como teste confirmatório e WG para aferir sobre a viabilidade do IP, com aumento de $400 \mathrm{x}$.

\subsubsection{Método 3 IP - Substituição do Método de Incubação e Diminuição do Tempo de Contato}


Alguns problemas foram observados no método anterior, assim, para os próximos ensaios tiveram algumas alterações na preparação na lâmina, ao invés de incubar os reagentes no Eppendorff de 2,0 mL, foram colocados separadamente direto na lâmina, de acordo com Medeiros (2010), isto com diminuição do tempo de incubação.

O mesmo procedimento de desagregação e homogeneização da suspensão foi realizado (conforme item 4.5). Uma alíquota de $50 \mu \mathrm{L}$ da suspensão homogeneizada foi colocada na lâmina e esperou-se secar à temperatura ambiente. Depois, foram adicionados 10 $\mu \mathrm{L}$ de metanol e esperou-se secar. Uma gota do reagente e uma gota do contra corante, presentes no kit Merifluor $^{\circledR}$, foram adicionadas e incubou-se a lâmina em câmara escura (placa de petri envolta por papel alumínio) por $30 \mathrm{~min}$ a $37^{\circ} \mathrm{C}$.

Após esse período, o poço foi lavado com $50 \mu \mathrm{L}$ de solução de água de lavagem presente no kit. A lavagem foi repetida mais duas vezes. Em seguida, foram adicionados 10 $\mu \mathrm{L}$ de DAPI, que ficou à temperatura ambiente por 10 min. O poço foi enxaguado com $50 \mu \mathrm{L}$ de HBSS 2 vezes.

Para finalizar, foram adicionados $10 \mu \mathrm{L}$ de IP, em temperatura ambiente, com tempo de contato de 10 min. O poço foi enxaguado com $50 \mu \mathrm{L}$ de HBSS duas vezes. Foi acrescentada mais uma etapa de lavagem de $50 \mu \mathrm{L}$ de água Milli-Q para evitar a formação de cristais. Então, uma gota do meio de montagem foi adicionada e por fim colocou-se a lamínula e as bordas da lâmina foram seladas com o selante Coverslip Sealant e encaminhadas para a leitura, com aumento de $400 \mathrm{x}$.

\subsubsection{Método 4 IP -Substituição da Solução Preparada de DAPI pela Solução Comercial Fluoroshield ${ }^{\mathrm{MM}}$ with DAPI e Preparação das lâminas com as suspensões de Giardia lamblia e Cryptosporidium parvum da Waterborne}

Nos ensaios subsequentes, a solução preparada de DAPI foi substituída pelo Fluoroshield ${ }^{\mathrm{TM}}$ with DAPI (Sigma, F6057), a qual requeria o uso de 3 a 4 gotas com tempo de contato de 15 min. A solução permitia melhor visualização do DAPI, facilitando a leitura. A dosagem do IP foi definida a partir de vários ensaios alternando os tempos de contato e fixando-se aquele que obteve o melhor resultado.

Os ensaios foram realizados com cistos de Giardia lamblia e oocistos de Crypostoridium parvum da Waterborne. 
Primeiramente, o procedimento de desagregação dos protozoários foi realizado (conforme protocolo do item 4.5). Uma alíquota de $5 \mu \mathrm{L}$ de cada suspensão foi disposta na lâmina para realizar uma nova contagem, em triplicata, visando obter um valor médio de (oo) cistos presentes em determinado volume. O procedimento de preparo da lâmina foi realizado da mesma forma, somente alterando a etapa do DAPI, onde 3 gotas foram adicionadas e permaneceu por um período de 10 min, seguindo da adição do IP. Finalizada a etapa citada, as lâminas foram encaminhadas para a contagem dos protozoários em microscópio com aumento de $400 \mathrm{x}$.

\subsubsection{Método 5 IP - Alterações do Tempo de Contato do DAPI e IP}

Algumas mudanças foram efetuadas nos ensaios como aumento do tempo de contato do DAPI e do IP para $15 \mathrm{~min}$, homogeneização das cepas por 4 min e agitação para tentar soltar os agregados formados nas suspensões da Waterborne. Igualmente, um ensaio foi realizado com a suspensão purificada na UNICAMP (Giardia spp.).

Alíquotas de $5 \mu \mathrm{L}$ de cada suspensão da Waterborne e $10 \mu \mathrm{L}$ da suspensão de Giardia spp. da UNICAMP foram inoculadas e o mesmo procedimento de preparação das lâminas foi realizado e a leitura foi alcançada com aumento de $400 \mathrm{x}$.

\subsubsection{Método 6 IP - Aumento do Volume do Inóculo das Suspensões de Giardia lamblia e Cryptosporidium parvum}

Como não foi possível visualizar os protozoários com o inóculo de $5 \mu \mathrm{L}$, optou-se por aumentar o volume para $50 \mu \mathrm{L}$ e os ensaios foram realizados em triplicata para cada suspensão da Waterborne e a leitura foi realizada com aumento de 400 x.

\subsubsection{Método 7 IP - Substituição da Suspensão Comercial de Giardia lamblia da Waterborne pela Suspensão Purificada da UNICAMP}

Após vários testes apresentando formação de agregados de cistos, fato que impossibilitou a contagem dos organismos, optou-se por trocar a suspensão de Giardia 
lamblia da Waterborne pela suspensão purificada de Giardia spp. pelo Laboratório de Protozoologia, Instituto de Biologia, da UNICAMP. Essa última suspensão foi utilizada para otimizar o tempo de contato do IP e fixar o volume de IP utilizado, o qual era proporcional ao volume inoculado. A suspensão de Cryptosporidium parvum não foi trocada porque não houve formação de agregados de oocistos que comprometessem a leitura em microscópio.

Um ensaio foi realizado com os mesmos procedimentos adotados anteriormente, utilizando um inóculo de $10 \mu \mathrm{L}$ de Giardia spp. e $50 \mu \mathrm{L}$ de Cryptosporidium parvum e a leitura foi realizada com aumento de $400 \mathrm{x}$.

\subsubsection{Método 8 IP - Otimização do Tempo de Incubação do IP}

Nos artigos que abordaram a utilização do IP, como (SCHUPP; ERLANDSEN, 1987; CAMPBELL et al., 1992; DOWD; PILLAI, 1997; ROBERTSON et al., 2000; VERGARACASTIBLANCO et al., 2000; FREIRE-SANTOS et al., 2000; BETANCOURT et al., 2003; OLVERA et al., 2008), entre outros, o tempo de incubação variava entre 5, 10 e 15 min., portanto, diversos ensaios foram realizados para verificar a influência do tempo de contato com a estimativa da viabilidade dos protozoários em estudo.

\subsection{Ensaios De Ozonização}

Anteriormente ao início dos ensaios de ozonização, um teste foi realizado para efetuar a contagem dos (oo) cistos, a fim de conhecer o número de protozoários a serem inoculados na amostra de água filtrada e, também, para estimar a viabilidade dos organismos alvos. Os ensaios foram realizados utilizando uma dosagem fixa de ozônio com dois tempos diferentes. Os ensaios foram avaliados com e sem o procedimento de separação imunomagnética e ficou dividido em duas etapas: i) a primeira, sem IMS, com dosagem definida e um valor de tempo, realizado em triplicata e o mesmo procedimento para o outro valor de tempo; e ii) na segunda, com IMS, portanto os seis ensaios foram repetidos.

A contagem dos protozoários e a estimativa da viabilidade foram realizados antes de iniciar cada etapa e o resultado foi utilizado para os seis ensaios seguintes. A Equação 7 permitiu a obtenção dos valores utilizados para o inóculo dos protozoários na amostra que era inserida na coluna de ozonização. 
Vol $_{\text {inóculo }}=\frac{\text { Vol }_{\text {contagem }} \times \text { Conc }_{\text {desejada }} \times V_{\text {Vol }} \text { desejado }}{\text { Média }}$

Equação 7

Em que:

Vol $_{\text {inóculo }}=$ Volume do inóculo de protozoários $(\mu \mathrm{L})$;

Vol $_{\text {contagem }}=$ Volume utilizado para efetuar a contagem de protozoários $(\mu \mathrm{L})$;

Conc $_{\text {desejada }}=$ Concentração desejada de protozoários (para os ensaios adotou-se 5000 (oo) cistos. $\left.L^{-1}\right)$;

$\operatorname{Vol}_{\text {desejado }}=$ Volume de amostra que irá receber o inóculo (3L);

Média $a_{\text {protozoários }}$ Média de protozoários contados nas lâminas.

Após a ozonização, durante a etapa 1, as amostras foram submetidas ao método de concentração utilizado (FCCa), seguida da preparação das lâminas e posteriormente, aos ensaios de viabilidade considerando o uso dos corantes vitais, o DAPI para o teste confirmatório e o IP para inferir a viabilidade dos (oo) cistos encontrados após a aplicação do ozônio com a finalidade de comparar com os resultados iniciais e após a desinfecção. Na etapa 2, após a FCCa, o pellet resultante era encaminhado para a etapa de IMS e, posteriormente, seguindo o mesmo procedimento realizado na etapa 1 .

\subsubsection{Descrição das Etapas Realizadas Para os Ensaios de Ozonização}

\subsubsection{Descrição da Etapa 1 - Ensaios com Dosagem Fixa de Ozônio e Tempos de 1 e 5 min sem IMS}

A Etapa 1 foi realizada com dosagem fixa de $5 \mathrm{mgO}_{3} \mathrm{~L}^{-1}$ e tempos de contato de 1 e 5 min, em triplicata.

Primeiramente, a caracterização da água filtrada foi efetuada, e em seguida, inoculouse uma determinada quantidade de (oo) cistos na água filtrada, depois de realizado o procedimento de homogeneização e contagem do inóculo descrito no Item 4.5. Em seguida, a amostra foi submetida ao processo de desinfecção com ozônio, onde permaneceu por $24 \mathrm{~h}$ para que ocorresse a sedimentação dos (oo) cistos. Uma alíquota de $100 \mathrm{~mL}$ foi retirada para análise dos parâmetros do ozônio e caracterização da água ozonizada. 
Após o tempo de repouso, os 2,9 L da coluna eram coletados e encaminhados para o procedimento de FCCa, descrito no Item 4.6. Depois de finalizada a última centrifugação, o sobrenadante era descartado até a marcação de $1 \mathrm{~mL}$, e esta alíquota era homogeneizada e encaminhada para a preparação das lâminas (descrito no Item 4.8).

Um volume de $150 \mu \mathrm{L}$ da alíquota resultante $(1 \mathrm{~mL})$, era disposto em 3 poços das lâminas de microscopia (50 $\mu \mathrm{L}$ em cada poço) e então, o restante era descartado. Em seguida, o procedimento descrito no Item 4.8 era iniciado.

Esse descarte de amostra, juntamente com protozoários, influenciava diretamente no cálculo de recuperação dos (oo) cistos. Este fato ocorria, devido à impossibilidade em se avaliar toda a amostra, pelos altos custos dos reagentes e dificuldade laboratorial.

Então, um cálculo era realizado, chamado de fator de multiplicação - FM, que é caracterizado pela multiplicação da quantidade de protozoários observados no microscópio por este fator, a fim de realizar os cálculos da porcentagem de organismos recuperados no método utilizado (Equação 8).

$F M=\frac{\text { Vol }_{\text {res }}}{\text { Vol }_{\text {analisado }}}$ Equação 8

Em que:

FM = Fator de multiplicação;

$\mathrm{Vol}_{\text {res }}=$ Volume restante após o descarte do sobrenadante $(\mathrm{mL})$;

$\mathrm{Vol}_{\text {analisado }}=$ Volume analisado no método.

No caso da Etapa 1, o FM era 6,67, ou seja (1000 $\mu \mathrm{L} / 150 \mu \mathrm{L})$.

\subsubsection{Descrição da Etapa 2 - Ensaios com Dosagem Fixa de Ozônio e Tempos de 1 e 5 min com IMS}

A Etapa 2 foi realizada com a mesma dosagem fixa de $5 \mathrm{mgO}_{3} \mathrm{~L}^{-1}$ e tempos de contato de 1 e 5 min, em triplicata, com a realização do método de IMS.

Para a realização da Etapa 2, o procedimento era similar até o método de concentração da amostra (descrita no Item 4.6). Na última centrifugação do método de FCCa, o sobrenadante era descartado até a marcação de $5 \mathrm{~mL}$ e então, enviado para o TLP, onde iniciaria o IMS (Item 4.7). 
Neste caso, como toda a amostra era processada no IMS, o FM era inexistente ou igual a $1(5 \mathrm{~mL} / 5 \mathrm{~mL})$, não influenciando no cálculo de recuperação de (oo) cistos. Assim, depois de finalizado, a preparação das lâminas era iniciada, igualmente ao item anterior.

\subsubsection{Calibração do Ozonizador}

Toda a etapa de calibração do equipamento foi realizada por Vieira (2016), que disponibilizou os dados obtidos. Esta fase será brevemente descrita a seguir.

O método iodométrico foi escolhido para obtenção da produção de ozônio, conforme descrito no Standard Methods for Examination of Water and Wastewater APHA, AWWA e WEF (2012).

De acordo com Rakness et al., (1996), o método iodométrico se baseia no princípio de que o íon iodeto é oxidado pelo ozônio a iodo, quando o ozônio é inserido através de bolhas em solução de iodeto de potássio (KI). Após o fim do borbulhamento de ozônio, o pH da solução de KI é imediatamente ajustado com ácido sulfúrico para 2,0 ou menos, visando completar as reações de oxidação.

O iodo precipita, e muda a coloração de incolor da solução original, para tons de amarelo e vermelho. O iodo então é titulado com o auxílio de amido, para chegar ao fim da reação, utilizando solução padronizada de tiossulfato de sódio. A massa de ozônio é determinada com base em relação estequiométrica de ozônio por iodo.

A relação estequiométrica é descrita na Equação 9.

$\mathrm{O}_{3}+2 \mathrm{I}^{-}+\mathrm{H}_{2} \mathrm{O}=\mathrm{I}_{2}+\mathrm{O}_{2}+2(\mathrm{OH})^{-}$

Equação 9

O iodo formado na reação (Equação 9) é titulado diretamente com o íon tissulfato (Equação 10).

$\mathrm{I}_{2}+2 \mathrm{~S}_{2} \mathrm{O}_{3}{ }^{2-}=2 \mathrm{I}^{-}+\mathrm{S}_{4} \mathrm{O}_{6}{ }^{2-}$

Equação 10

As Equações 9 e 10 demonstram o princípio químico do processo de quantificação da produção de ozônio. Na Equação 9 o ozônio provoca a oxidação do ânion iodeto, o qual forma iodo molecular, formando coloração amarelada/vermelha devido à precipitação. A Equação 10 demonstra o processo de titulação da amostra ozonizada com tiossulfato de sódio, 
em que a formação de iodeto irá causar o clareamento da solução até esta passar de tons amarelados para incolor, o ponto final da reação é alcançado com o amido.

\subsubsection{Descrição do Ensaio de Ozonização}

Para iniciar o ensaio, preparava-se uma solução de iodeto de potássio (KI) a $2 \%$, (20 g de KI para cada 1,0 L de água destilada). A solução era conservada em local escuro e refrigerado.

Um volume de solução de KI a $2 \%$ era adicionado à coluna de ozonização, o qual foi adotado durante todo o ensaio (3,0 L). O mesmo ocorria para o frasco lavador de gás (1,0 L).

A vazão de ozônio e a tensão eram ajustadas conforme desejado. Depois, era ozonizado durante o tempo de contato adotado. Após o tempo de contato, os volumes das amostras da coluna de ozonização e do frasco lavador de gás eram coletados.

As amostras eram fixadas com solução de ácido sulfúrico $\left(\mathrm{H}_{2} \mathrm{SO}_{4}\right)$ 1,0 N, utilizando 2 $\mathrm{mL}$ de ácido para cada $100 \mathrm{~mL}$ de amostra. As amostras eram tituladas com tiossulfato de sódio até a coloração amarelo palha. Em seguida, 1,0 mL de solução indicadora de amido era acrescentada para cada $100 \mathrm{~mL}$ de amostra. A amostra apresentava uma coloração azulada. Então, retornava-se à titulação com tiossulfato de sódio até que desaparecesse a coloração azulada.

$\mathrm{O}$ volume de tiossulfato utilizado $\left(\mathrm{V}_{\text {tio }}\right)$ era anotado para obtenção das produções de ozônio e, então, o ensaio era repetido para as demais vazões de ozônio e tensões.

\subsubsection{Determinação da Produção de Ozônio}

O volume de solução de tiossulfato de sódio necessário para titular a amostra de KI 2 \% ozonizada, foi usado para calcular a produção de ozônio no intervalo de tempo utilizado. As produções de ozônio na coluna de ozonização, no frasco lavador de gás e a total foram determinadas segundo as Equações 11 e 12.

$P=\frac{N_{T I O} \times\left(V_{T I O}-V_{B}\right) \times V_{K I} \times 1440}{V_{A M} \times t}$

Equação 11

$P_{\text {TOTAL }}=P_{\text {COLUNA }}+P_{F L V}$

Equação 12

Em que: 
P: Produção de ozônio $\left(\mathrm{gO}_{3} / \mathrm{h}\right)$;

$\mathrm{N}_{\text {TIO }}$ : Normalidade do tiossulfato de sódio;

$\mathrm{V}_{\text {TIO }}$ : Volume consumido de tiossulfato de sódio na titulação da amostra $(\mathrm{mL})$;

$\mathrm{V}_{\mathrm{B}}$ : Volume consumido de tiossulfato de sódio na titulação do branco (mL), (Viera, 2016 encontrou valor de $V_{B}=0$, e foi adotado para o restante dos ensaios);

$\mathrm{V}_{\mathrm{KI}}$ : Volume da solução de iodeto de potássio a $2 \%$ acrescentado na coluna de ozonização ou no frasco lavador de gás $(\mathrm{mL})$;

$\mathrm{V}_{\mathrm{AM}}$ : Volume da amostra $(\mathrm{mL})$;

t: Tempo de contato (min);

1440: Fator de conversão;

P TOtAL: Produção total de ozônio $\left(\mathrm{gO}_{3} / \mathrm{h}\right)$;

PColuna: Produção de ozônio na coluna de ozonização ( $\left.\mathrm{gO}_{3} / \mathrm{h}\right)$;

$\mathrm{P}_{\mathrm{FLV}}$ : Produção de ozônio no frasco lavador de gás $\left(\mathrm{gO}_{3} / \mathrm{h}\right)$.

A produção de ozônio calculada pode ser relacionada à dosagem de ozônio na coluna de ozonização (Equação 13). Esta dosagem é um valor médio da concentração de ozônio durante o tempo de contato. 
$D=\frac{P \times t \times 1000}{V \times 60}$

Equação 13

Em que:

D: Dosagem de ozônio (mg. $\left.\mathrm{L}^{-1}\right)$;

P: Produção de ozônio $\left(\mathrm{gO}_{3} / \mathrm{h}\right)$;

t: Tempo de contato (min);

V: Volume ozonizado (L)

Com as Equações 11 a 13, as curvas de correlação entre a vazão de ozônio com a produção de ozônio foram obtidas.

\subsubsection{Valores Utilizados para Calibração do Gerador de Ozônio}

Os valores indicados na Tabela 1 foram utilizados para calibrar o gerador de ozônio. Na Tabela 2 estão apresentados os resultados da produção de ozônio obtida pela calibração do ozonizador realizada por Vieira (2016).

Tabela 1: Valores utilizados para a calibração do ozonizador.

\begin{tabular}{cc}
\hline Tensão no aparelho ozonizador (\%) & $40,60,80$ e 100 \\
\hline Vazão de ozônio $\left(\right.$ L.min $\left.{ }^{-1}\right)$ & 0,$5 ; 1,0 ; 1,5$ e 2 \\
\hline Tempo de contato do ozônio com solução de KI (min) & 5 \\
\hline Volume de amostra para titulação (mL) & 100 \\
\hline Normalidade do tiossulfato de sódio (N) & 0,025 \\
\hline Volume de KI na coluna de ozonização (L) & 1 \\
\hline Volume de KI no frasco lavador de gás (L) & 3 \\
\hline
\end{tabular}


Tabela 2: Produção de ozônio obtida através da tensão do ozonizador e da vazão aplicada no aparelho.

\begin{tabular}{ccc}
\hline Tensão (\%) & Vazão $\left({\left.\mathrm{L} \cdot \mathrm{min}^{-1}\right)}^{1}\right)$ & Produção de Ozônio $\left(\mathrm{gO}_{3} \cdot \mathrm{h}^{-1}\right)$ \\
\hline 40 & 0,5 & 0,03 \\
& 1 & 0,51 \\
& 1,5 & 0,72 \\
\hline \multirow{2}{*}{60} & 2 & 0,09 \\
& 0,5 & 0,63 \\
& 1 & 1,15 \\
& 1,5 & 1,09 \\
\multirow{2}{*}{80} & 2 & 0,3 \\
& 0,5 & 1,1 \\
& 1 & 2,52 \\
& 1,5 & 2,53 \\
\hline 00 & 2 & 0,78 \\
& 0,5 & 2,26 \\
& 1 & 3,33 \\
& 1,5 & 4,91 \\
\hline
\end{tabular}

Na Tabela 2, a tensão refere-se à tensão regulada no aparelho ozonizador, a vazão é a de ozônio ajustada através de rotâmetro, medida em litros por minuto e por fim, a produção de ozônio é dada em gramas de ozônio por hora.

A máxima produção de ozônio obtida foi de $4,91 \mathrm{gO}_{3} \cdot \mathrm{h}^{-1}$, este valor representa 70,14 $\%$ da produção que o aparelho pode fornecer, que é de $7 \mathrm{gO}_{3} \cdot \mathrm{h}^{-1}$, segundo o fabricante.

Através das curvas de produção (Figura 8), o modelo exponencial foi ajustado a cada curva, e foram obtidas equações que relacionam a vazão de ozônio com a produção do mesmo, para cada tensão utilizada. Nos cálculos de produção de ozonização não foi constatada a presença de ozônio no off gas, realizada por titulação volumétrica, pois todo o ozônio foi consumido na coluna de ozonização, pelo iodeto de potássio $2 \% \mathrm{~m} / \mathrm{v}$. 


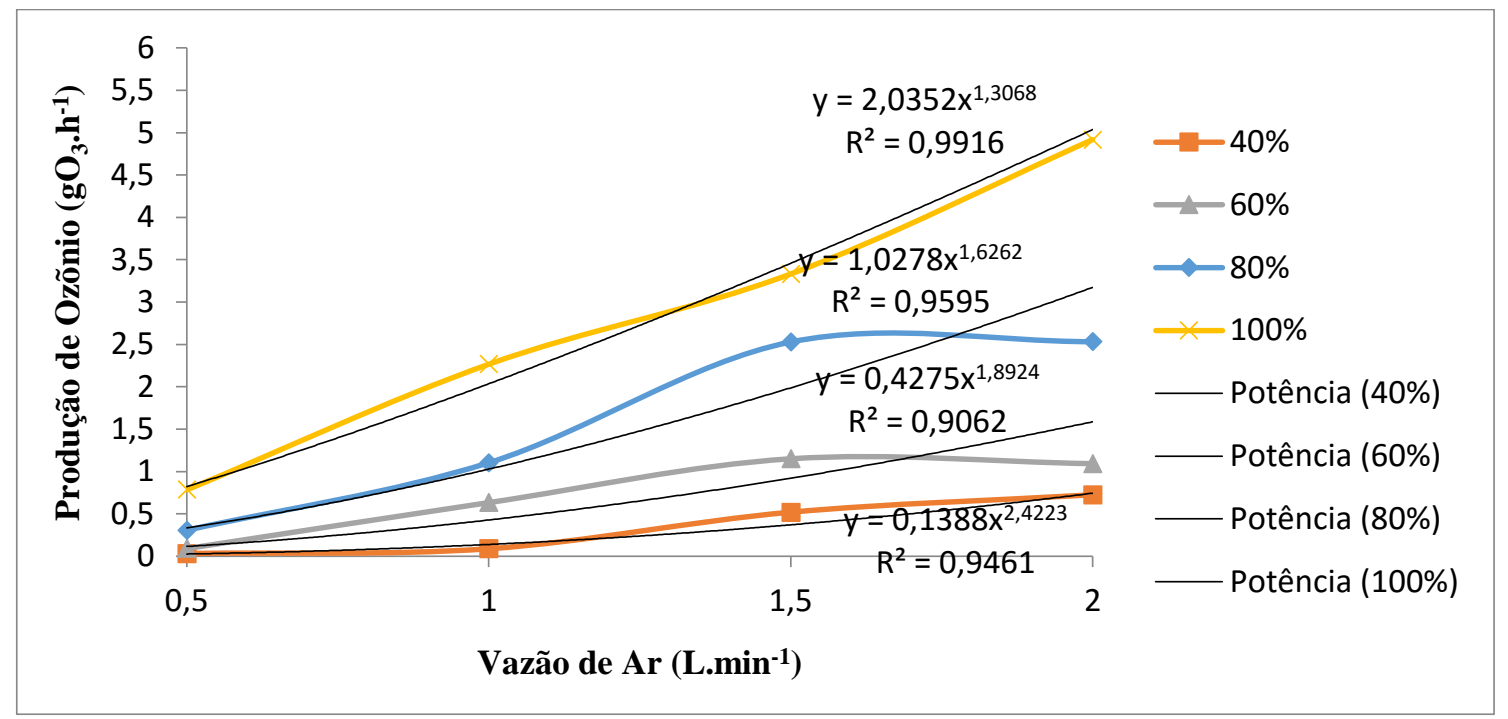

Figura 8: Produção de ozônio $\left(\mathrm{gO}_{3} \cdot \mathrm{h}^{-1}\right)$ obtida através da regulação da vazão de ozônio $\left(\mathrm{L} \cdot \mathrm{min}^{-1}\right)$ e tensão adotada (\%) (VIEIRA, 2016).

\subsubsection{Instalação Experimental}

Os ensaios de ozonização foram realizados em uma instalação experimental, em escala piloto, nas dependências do Laboratório LATAR (Figura 9). Os constituintes básicos para a realização dos ensaios foram: coluna de ozonização, frascos lavadores de gás (off-gas) e gerador de ozônio. 


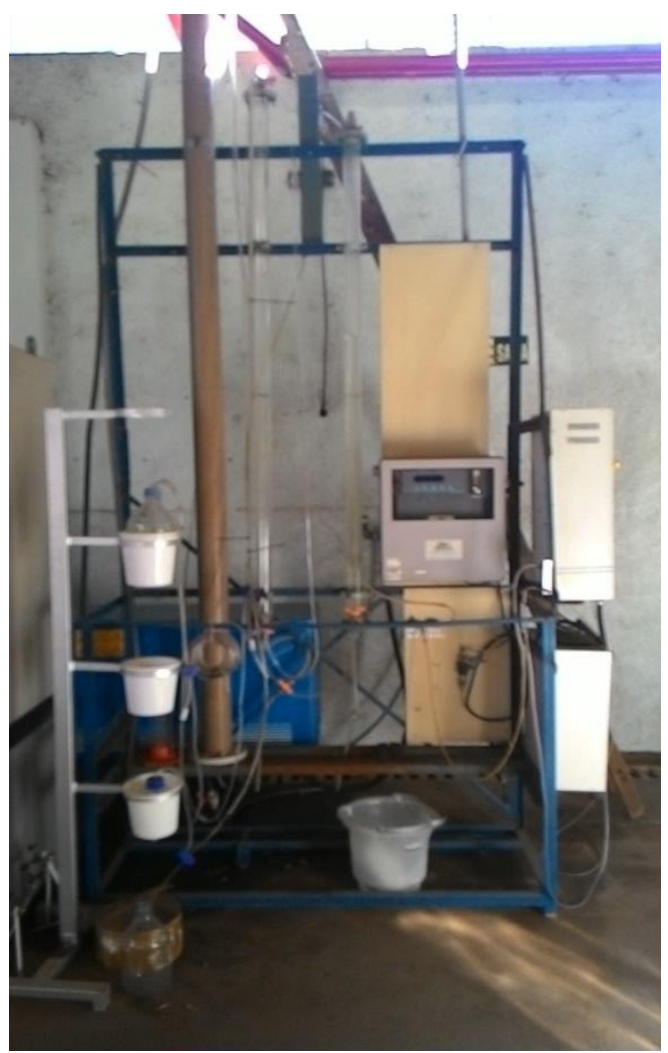

Figura 9: Unidade piloto de ozonização construída no LATAR.

\subsubsection{Coluna de Ozonização}

A coluna de ozonização foi construída em acrílico transparente, possui 2,05 m de altura, $55 \mathrm{~mm}$ de diâmetro externo, $49 \mathrm{~mm}$ de diâmetro interno, $3 \mathrm{~mm}$ de espessura e possui capacidade total de 4,4 L, sendo utilizado um volume de $3 \mathrm{~L}$ para os ensaios. No topo da coluna encontrava-se um registro esfera de PVC para alimentação da mesma e uma saída acoplada com uma mangueira que era destinada para a coleta do off-gas e na base encontravase o mesmo registro esfera, que era utilizado para coleta e descarte da amostra da coluna de ozonização (Figura 10). 


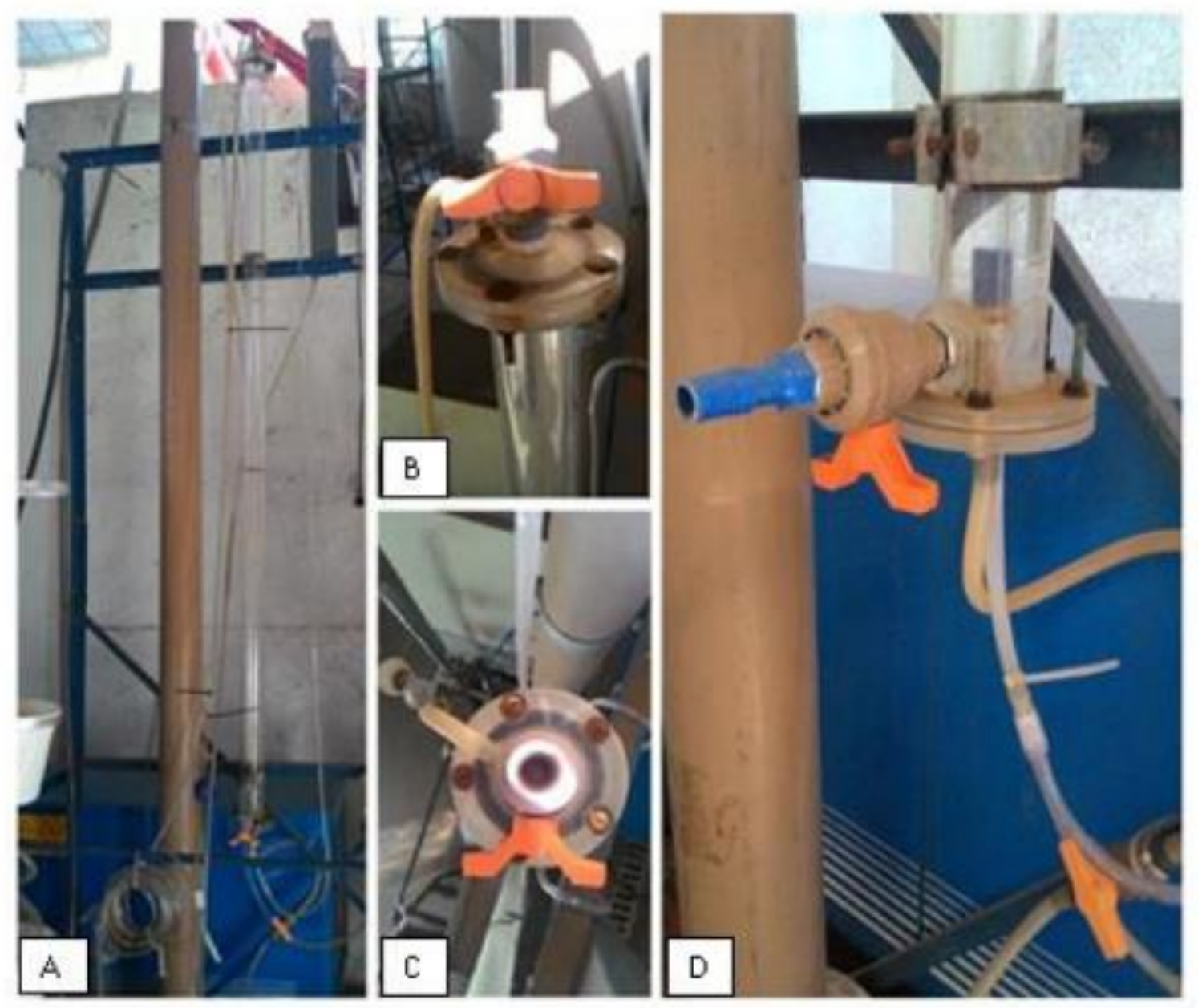

Figura 10: Detalhes da coluna de ozonização. a) coluna em acrílico; b) topo da coluna com o registro esfera; c) vista superior da coluna (alimentação) e d) base da coluna e válvula de descarte da amostra.

O gás ozônio produzido no aparelho ozonizador era transferido para a coluna através de uma mangueira cristal de 1/8 polegada de diâmetro. A coluna era vedada nas extremidades (superior e inferior) com tampa acrílica, presa com parafusos e borboletas.

Tanto a alimentação quanto a limpeza da coluna foram realizadas manualmente, utilizando um funil, que era colocado dentro do registro esfera aberto. Ao chegar à coluna, o ozônio era difundido no meio líquido após passar por uma pedra porosa cilíndrica, localizada na base da coluna. A pedra porosa tinha a função de formar pequenas bolhas de gás ascensionais no líquido da coluna, promovendo maior difusão do gás através do aumento da superfície de contato entre o gás e o líquido. 


\subsubsection{Frasco Lavador de Gás}

O gás ozônio que não era transferido para o meio líquido, era capturado por um frasco lavador preenchido com solução de iodeto de potássio (KI) a $2 \%$. Este procedimento era realizado para a quantificação deste off-gas (Método Iodométrico - APHA, AWWA e WEF, 2012) e decomposição do ozônio para evitar a liberação para a atmosfera. Um frasco Schott, com capacidade de $2 \mathrm{~L}$, foi utilizado como lavador do off-gas (Figura 11). O frasco era conectado ao topo da coluna de ozonização através de uma mangueira de silicone e sua tampa era composta por um tubo de extremidade porosa mergulhada na solução de iodeto de potássio a $2 \%$.

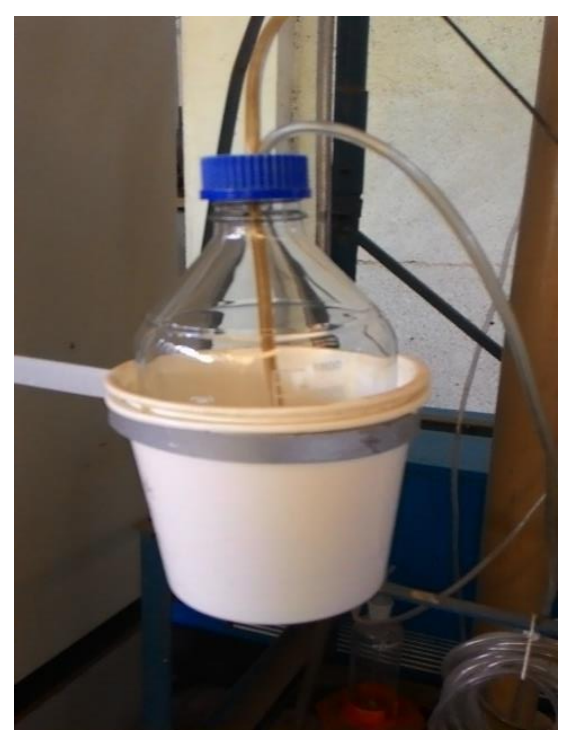

Figura 11: Frasco lavador de gás.

\subsubsection{Gerador de Ozônio}

O gerador de ozônio utilizado era o modelo PXZ3507, EAGLESAT ${ }^{\circledR}$. O aparelho é alimentado por oxigênio separado do ar atmosférico através de um gerador de oxigênio, que utiliza peneiras de adsorção para a separação dos gases.

O gerador de ozônio era do tipo Corona Discharge (Figura 12) e composto por um gerador de alta tensão, chave seletora de tensão com $0,20 \%, 40 \%, 60 \%, 80 \%$ e 100\%, válvulas de controle de pressão e vazão de oxigênio. A pressão foi mantida em 0,5 bar durante os experimentos. 


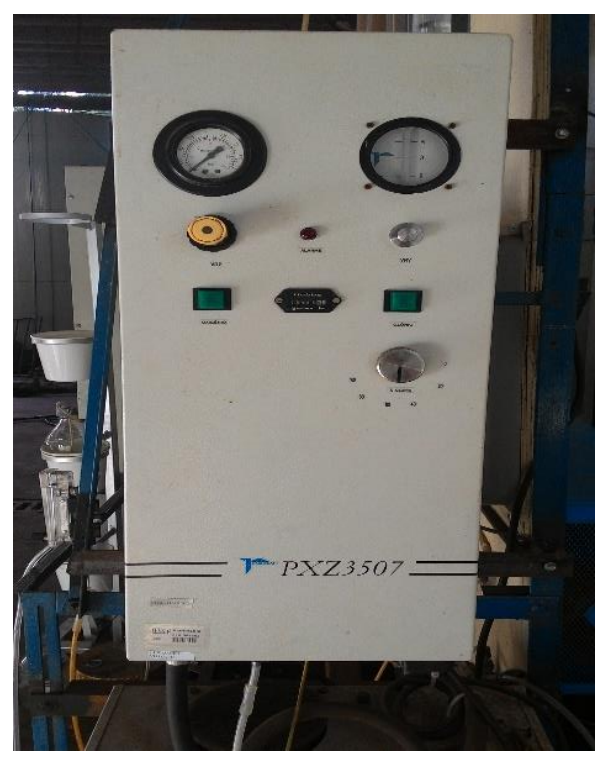

Figura 12: Gerador de ozônio.

Após a realização dos cálculos realizados nos próximos itens, a dosagem de ozônio era adicionada ao sistema e a vazão de ozônio e a tensão elétrica eram ajustadas no aparelho. O aparelho ozonizador possui capacidade máxima de geração de ozônio de até $7,7 \mathrm{~g} \mathrm{O}_{3} \mathrm{~h}^{-1}$. Entretanto, existem alguns empecilhos no processo, como os fatores ambientais, onde a temperatura do gás de alimentação que interfere no processo e com isso impossibilita a produção máxima do equipamento. A vazão de ozônio/oxigênio foi regulada através de um rotâmetro de marca Dwyer modelo RMA (Figura 13), acoplado ao equipamento gerador de ozônio, graduado de 0,5 a $5 \mathrm{~L} \mathrm{O}_{2} / \mathrm{min}$.

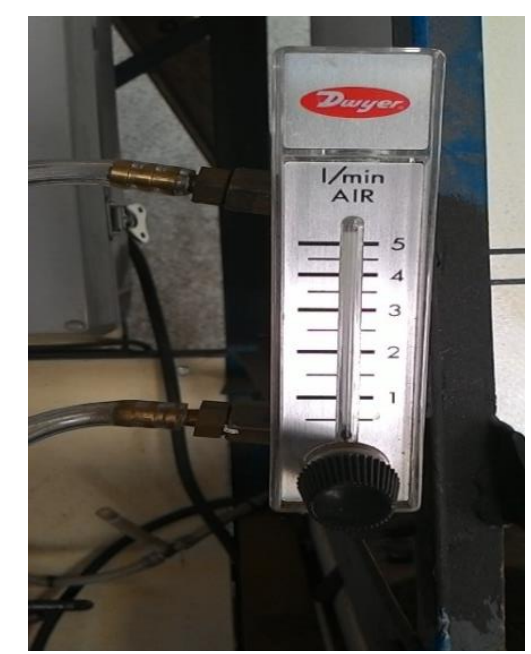

Figura 13: Rotâmetro utilizado para regular a vazão de oxigênio. 
Uma dosagem de ozônio de $5 \mathrm{mgO}_{3} \cdot \mathrm{L}^{-1}$ foi fixada para todos os ensaios, conforme resultados obtidos por Wickramanayake et al., (1984), Finch et al., (1993), Widmer et al., (2002), Khalifa, El Temsahy e Abou (2001), Soares (2007) e Miranda (2014).

O tempo de contato foi de 1,0 min para a primeira condição e depois foi aumentado para 5 min para a segunda condição (Tabela 3). Outros parâmetros como, turbidez, cor aparente, temperatura e $\mathrm{pH}$ foram medidos, antes e depois de cada ensaio.

Tabela 3: Etapa 1 do ensaio de ozonização, sem IMS.

\begin{tabular}{cccc}
\hline Etapa & Dose $\left(\mathrm{mgO}_{3} \cdot \mathrm{L}^{-1}\right)$ & Tempo de contanto $(\mathrm{min})$ & $\mathrm{N}^{\mathrm{o}}$ de repetições dos ensaios \\
\hline \multirow{2}{*}{1} & 5 & 1 & 3 \\
& 5 & 5 & 3 \\
\hline
\end{tabular}

Posteriormente, esses parâmetros foram repetidos para a etapa 2, agora com a fase de IMS, e os dados estão apresentados na Tabela 4.

Tabela 4: Etapa 2 do ensaio de ozonização, com IMS.

\begin{tabular}{cccc}
\hline Etapa & Dose $\left(\mathrm{mgO}_{3} \cdot \mathrm{L}^{-1}\right)$ & Tempo de contanto (min) & $\mathrm{N}^{\mathrm{o}}$ de repetições dos ensaios \\
\hline \multirow{2}{*}{2} & 5 & 1 & 3 \\
& 5 & 5 & 3 \\
\hline
\end{tabular}

4.12.8.

\subsubsection{Ensaio de Desinfecção}

Para iniciar o ensaio de desinfecção, o gerador de ozônio era ligado previamente, por 30 min para aquecer. Enquanto isso, dentro das instalações do LATAR, as vidrarias, bureta e todos os utensílios eram devidamente preparados e higienizados. Todas as vidrarias que entravam em contato com a água de estudo, que era produzida a partir da água filtrada e posterior inóculo de (oo) cistos de Giardia spp. e Cryptosporidium parvum, eram enxaguadas com Tween 80 a $0,1 \%$.

Em seguida, 3 L da água de estudo era coletada e deixada sob agitação em um béquer, para receber o inóculo dos parasitos. As suspensões eram removidas da geladeira para ficar à temperatura ambiente e posteriormente eram homogeneizadas em aparelho vortéx por 2 min cada e esse procedimento era repetido por mais 2 vezes, para cada suspensão. Então, com o 
auxílio de uma pipeta automática, $150 \mu \mathrm{L}$ da suspensão purificada de Giardia spp. e $150 \mu \mathrm{L}$ da suspensão comercial de Cryptosporidium parvum eram adicionados à água de estudo e a amostra era mantida por mais 15 min sob agitação.

A água que estava na coluna de ozonização era descartada e preenchida novamente com água potável para limpar as sujidades e descartada em seguida.

Posteriormente, a água de estudo homogeneizada era colocada na coluna de ozonização até a marcação de 3 L, com o auxílio de um balão volumétrico e um funil, lembrando-se de manter o registro da base da coluna fechado para receber a amostra. Um volume de 1,0 L de KI era colocado no frasco do off-gas e $500 \mathrm{~mL}$ da mesma solução era disposto no coletor de espuma que ficava localizado logo abaixo e todas as mangueiras eram devidamente conectadas.

Antes do ensaio, fechava-se o registro do topo da coluna, ajustava-se o rotâmetro para a vazão a ser utilizada, a pressão era colocada em 0,5 bar e então o gerador de ozônio era ligado, pelo tempo desejado e o ensaio era cronometrado. No final do tempo de contato, o ozônio era desligado e o compressor de ar permanecia ligado por mais 1,0 min para, então, ser desligado.

Ao desligar o equipamento, fechava-se o registro que libera ar para a coluna de ozonização, o registro do topo da coluna era aberto e a mangueira de silicone do frasco lavador de gás era desconectada para realizar análise de off-gas. Assim, após finalizar essas operações, um volume de $100 \mathrm{~mL}$ era coletado da base da coluna para ser destinado à realização das análises de concentração de ozônio residual, turbidez, cor aparente, temperatura e $\mathrm{pH}$.

A amostra contida na coluna de ozonização (2,9 L) era coletada 24 h depois do ensaio, visando a sedimentação dos (oo) cistos e encaminhada para o método de concentração, descrito no item 4.6, e era efetuada a lavagem da coluna com o uso de água potável.

\subsubsection{Procedimento Geral para a Realização das Análises da Concentração de Ozônio Residual e do Off-gas}

As análises de concentração de ozônio residual e do off-gas foram feitas segundo descrito em APHA, AWWA e WEF (2012), considerando o método índigo, através do uso de ampolas AccuVac ${ }^{\circledR}$ da marca HACK (Método 8311), na faixa de 0,01 - 1,50 $\mathrm{mgO}_{3} \cdot \mathrm{L}^{-1}$, utilizando o espectrofotômetro da marca HACK, modelo DR 2800 e pelo método 
iodométrico, respectivamente. As análises foram executadas imediatamente após a realização do ensaio.

\subsubsection{Balanço de Massa do Ozônio Dissolvido}

O balanço de massa do ozônio permite quantificar a massa ou concentração de ozônio que foi transferido e consumido durante os ensaios de ozonização e associar estes resultados à eficiência de inativação dos microrganismos indicadores (Soares, 2007).

As Equações 14 até 19 possibilitam a realização dos cálculos e foram realizadas de acordo com estudos de Soares (2007) e Medeiros (2013).

Durante o ensaio de ozonização, uma massa de ozônio é aplicada na amostra inserida na coluna de ozonização. Esta massa pode ser obtida a partir da equação 14.

$M_{A}=D x V$

Equação 14

Em que:

$\mathrm{M}_{\mathrm{A}}=$ Massa aplicada de ozônio (mg);

$\mathrm{D}=$ Dosagem de ozônio aplicado (mg. $\left.\mathrm{L}^{-1}\right)$;

$\mathrm{V}=$ Volume de amostra ozonizada (L).

Esta massa total de ozônio aplicada $\left(\mathrm{M}_{\mathrm{A}}\right)$ divide-se em: i) massa transferida para o meio líquido $\left(\mathrm{M}_{\mathrm{T}}\right)$ e massa não transferida, que, por sua vez, foi quantificada no off-gas (MFf-GAS). A $\mathrm{M}_{O F F-G A S}$ e $\mathrm{M}_{\mathrm{T}}$ podem ser calculadas pelas Equações 15 e 16, respectivamente.

$M_{O F F-G A S}=\frac{N_{T I O} \times V_{T I O} \times V_{O F F-G A S} \times 24.000}{V_{A M}}$

Equação 15

Em que:

MofF-GAS: Massa de ozônio não transferida quantificada no off-gas (mg);

$\mathrm{N}_{\text {TIO }}$ : Normalidade do tiossulfato de sódio $(\mathrm{N})$;

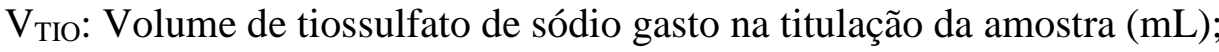

V OFF-GAS: Volume de solução de KI (2\%) adicionado ao frasco lavador de gás (L);

$\mathrm{V}_{\mathrm{AM}}$ : Volume de amostra de KI (2\%) titulada (mL).

$M_{T}=M_{A}-M_{O F F-G A S}$

Equação 16 
Em que:

$\mathrm{M}_{\mathrm{T}}=$ Massa de ozônio transferida ao meio líquido (mg);

$\mathrm{M}_{\mathrm{A}}=$ Massa total de ozônio aplicada (mg);

$\mathrm{M}_{O F F-G A S}=$ Massa de ozônio não transferida quantificada no off-gas (mg).

A massa de ozônio transferida ao meio líquido $\left(\mathrm{M}_{\mathrm{T}}\right)$ ainda pode ser dividida em: i) massa residual $\left(\mathrm{M}_{\mathrm{R}}\right)$ e ii) massa consumida $\left(\mathrm{M}_{\mathrm{C}}\right)$. A massa residual e a consumida podem ser calculadas conforme Equação 17 e 18, respectivamente.

$M_{R}=\left[O_{3}\right]_{R} \times V$

Equação 17

Em que:

$\mathrm{M}_{\mathrm{R}}=$ Massa residual (mg);

$\left[\mathrm{O}_{3}\right]_{\mathrm{R}}=$ Concentração de ozônio residual $\left(\mathrm{mg} . \mathrm{L}^{-1}\right)$;

$\mathrm{V}=$ Volume de amostra ozonizada (L).

$M_{C}=M_{T}-M_{R}$

Equação 18

\section{Em que}

$\mathrm{M}_{\mathrm{C}}=$ Massa consumida $(\mathrm{mg})$;

$\mathrm{M}_{\mathrm{T}}=$ Massa de ozônio transferida ao meio líquido (mg);

$\mathrm{M}_{\mathrm{R}}=$ Massa residual (mg).

Portanto, a concentração de ozônio consumido $\left[\mathrm{O}_{3}\right]_{\mathrm{C}}$ pode ser estimada pela Equação 19.

$\left[\mathrm{O}_{3}\right]_{C}=D-\left(\left[\mathrm{O}_{3}\right]_{R}+\left[\mathrm{O}_{3}\right]_{\text {OFF-GAS }}\right)$ Equação 19

Em que:

$\left[\mathrm{O}_{3}\right]_{\mathrm{C}}=$ Concentração de ozônio consumido $\left(\mathrm{mg} \cdot \mathrm{L}^{-1}\right)$;

D: Dosagem de ozônio aplicada (mg. $\left.\mathrm{L}^{-1}\right)$;

$\left[\mathrm{O}_{3}\right]_{\mathrm{R}}$ : Concentração de ozônio residual $\left(\mathrm{mg}^{\mathrm{L}} \mathrm{L}^{-1}\right)$; 
$\left[\mathrm{O}_{3}\right]_{\text {OFF-GAS: }}$ Concentração de ozônio no off-gas $\left(\mathrm{mg} . \mathrm{L}^{-1}\right)(\mathrm{Obs} .:$ razão entre a massa de ozônio no off-gas (MFF-GAS $)$ e o volume de amostra ozonizada (L)).

\subsection{Manipulação de Amostras Contendo Protozoários e Disposição Final De Resíduos}

Os procedimentos analíticos realizados no laboratório que consideravam o manejo de materiais contendo protozoários eram realizados sob condições de segurança fazendo o devido uso de Equipamentos de Proteção Individual - EPI como luvas de látex, jaleco, máscara, óculos protetores, entre outros. O material descartável era destinado ao lixo infectante disponível no laboratório, e o material que era reutilizável era lavado e desinfetado com Extran $2 \%$ e hipoclorito de sódio a $0,5 \%$. 


\section{RESULTADOS E DISCUSSÃO}

\subsection{Preparação da água de estudo}

Vários testes experimentais foram realizados para definir a dosagem de caulinita e ácido húmico a serem utilizados nos ensaios e estão apresentados na Tabela 5. Os testes foram efetuados em misturador elétrico onde quantidades controladas dos reagentes eram adicionadas progressivamente, e os parâmetros de turbidez e cor aparente eram monitorados após agitação de $15 \mathrm{~min}$ a $500 \mathrm{rpm}$.

Tabela 5: Valores obtidos da dosagem de caulinita e ácido húmico.

\begin{tabular}{cccc}
\hline $\begin{array}{c}\text { Caulinita } \\
\left(\mathrm{mg} . \mathrm{L}^{-1}\right)\end{array}$ & $\begin{array}{c}\text { Ácido Húmico } \\
\left(\mathrm{mg} . \mathrm{L}^{-1}\right)\end{array}$ & $\begin{array}{c}\text { Turbidez } \\
(\mathrm{uT})\end{array}$ & $\begin{array}{c}\text { Cor aparente } \\
(\mathrm{uH})\end{array}$ \\
\hline 50 & 10 & 26 & 146 \\
$\mathbf{9 0}$ & $\mathbf{1 0}$ & $\mathbf{5 4 , 8}$ & $\mathbf{1 6 5}$ \\
\hline
\end{tabular}

Então, de acordo com os resultados apresentados na Tabela 5, foram definidas as dosagens de 18 gramas de caulinita e 2 gramas de ácido húmico para cada batelada de 200 litros de água de estudo.

Maciel (2014) e Giglio (2015) prepararam água de estudo com turbidez de 100 uT e dosaram de 0,1 g.L $L^{-1}$ e 0,16 g.L. $L^{-1}$ de caulinita, respectivamente. Nesta pesquisa foram necessários 0,09 g.L $\mathrm{L}^{-1}$ de caulinita para atingir turbidez de 54,8 uT, ou seja, quase metade do valor utilizado pelos autores citados. Este fato pode estar associado à variação da qualidade da água do poço da EESC/USP e/ou às alterações das características da caulinita e partindo deste pressuposto, este tipo de ensaio não pode ser generalizado.

\subsection{Caracterização da Água de Estudo}

A caracterização da água de estudo foi realizada por meio de análises de $\mathrm{pH}$, potencial zeta, temperatura, turbidez, cor verdadeira, cor aparente, alcalinidade, condutividade, absorbância 254 nm, COT, metais e coliformes (Tabela 6). 
Tabela 6: Caracterização da água de estudo com a adição de caulinita e ácido húmico.

\begin{tabular}{|c|c|c|}
\hline Parâmetro & Unidade & Valor \\
\hline Turbidez & $\mathrm{uT}$ & 54,8 \\
\hline Cor aparente & $\mathrm{Pt}-\mathrm{Co}$ & 165 \\
\hline Cor verdadeira & $\mathrm{uH}$ & 86,8 \\
\hline Temperatura & ${ }^{\circ} \mathrm{C}$ & 25 \\
\hline $\mathrm{pH}$ & - & 6,64 \\
\hline Potencial zeta & $\mathrm{mV}$ & $25,2 \pm 5,46$ \\
\hline Condutividade & $\mu \mathrm{S} . \mathrm{cm}^{-1}$ & 60,7 \\
\hline Absorbância & $254 \mathrm{~nm}$ & 0,259 \\
\hline Alcalinidade & $\mathrm{mgCaCO}_{3} \cdot \mathrm{L}^{-1}$ & 51,35 \\
\hline Escherichia coli & NMP. $100 \mathrm{~mL}^{-1}$ & 1 \\
\hline Coliformes totais & NMP. $100 \mathrm{~mL}^{-1}$ & 1 \\
\hline Dureza & $\mathrm{mg} \mathrm{CaCO} \cdot \mathrm{L}^{-1}$ & 0 \\
\hline COT & mg COT.L $\mathrm{L}^{-1}$ & 2,2045 \\
\hline Alumínio & $\mathrm{mg} \mathrm{Al.L^{-1 }}$ & 0,69 \\
\hline Chumbo & $\mathrm{mg} \mathrm{Pb} . \mathrm{L}^{-1}$ & $<\mathrm{LD}$ \\
\hline Cádmio & $\operatorname{mg~Cd} . \mathrm{L}^{-1}$ & 0,019 \\
\hline Ferro & $\mathrm{mg} \mathrm{Fe} . \mathrm{L}^{-1}$ & 0,260 \\
\hline Manganês & $\operatorname{mg~Mn.L^{-1}}$ & 0,006 \\
\hline Mercúrio & $\operatorname{mg~Hg} . \mathrm{L}^{-1}$ & $<\mathrm{LD}$ \\
\hline
\end{tabular}

Nota: $<\mathrm{LD}=$ menor que o limite de detecção.

Ao observar os dados obtidos da caracterização da água de estudo (Tabela 6), com os diagramas de seleção da flotação de Valade et al., (2009) (Figuras 1 e 2), nota-se que os valores de turbidez, cor verdadeira e COT se enquadram na tecnologia selecionada.

\subsection{Ensaios de Tratabilidade da Água de Estudo}

\subsubsection{Construção do Diagrama de Coagulação}


Para a construção do diagrama de coagulação, foram fixados os parâmetros iniciais que estão apresentados na Tabela 7, de acordo com resultados obtidos por Edzwald e Haarhoff (2011) e Di Bernardo, Dantas e Voltan (2011).

Tabela 7: Parâmetros fixados para a construção do diagrama de coagulação.

\begin{tabular}{ccc}
\hline Parâmetro & Unidade & Valor \\
\hline Gradiente de mistura rápida & $\mathrm{s}^{-1}$ & 700 \\
Tempo de mistura rápida & $\mathrm{s}$ & 15 \\
Gradiente de mistura lenta & $\mathrm{s}^{-1}$ & 50 \\
Tempo de mistura lenta & $\min$ & 4 \\
Taxa de recirculação & $\%$ & 5 \\
Pressão de saturação & bar & 5 \\
Tempo de saturação & min & 10 \\
Tempo de flotação & min & 5 \\
\hline
\end{tabular}

A partir destes parâmetros, foram realizados vários ensaios variando as dosagens de coagulante (Policloreto de Alumínio - PAC, teor de $\mathrm{Al}_{2} \mathrm{O}_{3}$ 17,56\%) e alcalinizante (Hidróxido de Sódio $-\mathrm{NaOH}$ ). Estes ensaios resultaram em diferentes valores de remoção de turbidez e cor aparente na água clarificada, permitindo a construção dos diagramas de coagulação (Figuras 14 e 15).

Dois pontos "ótimos" de coagulação foram selecionados em função do melhor desempenho na remoção de turbidez e cor aparente e estão indicados no diagrama. A seta tracejada corresponde ao ponto "ótimo" para o tratamento somente com PAC, ou seja, sem alcalinizante e, a seta contínua indica o ponto "ótimo" para o tratamento com PAC e alcalinizante. 


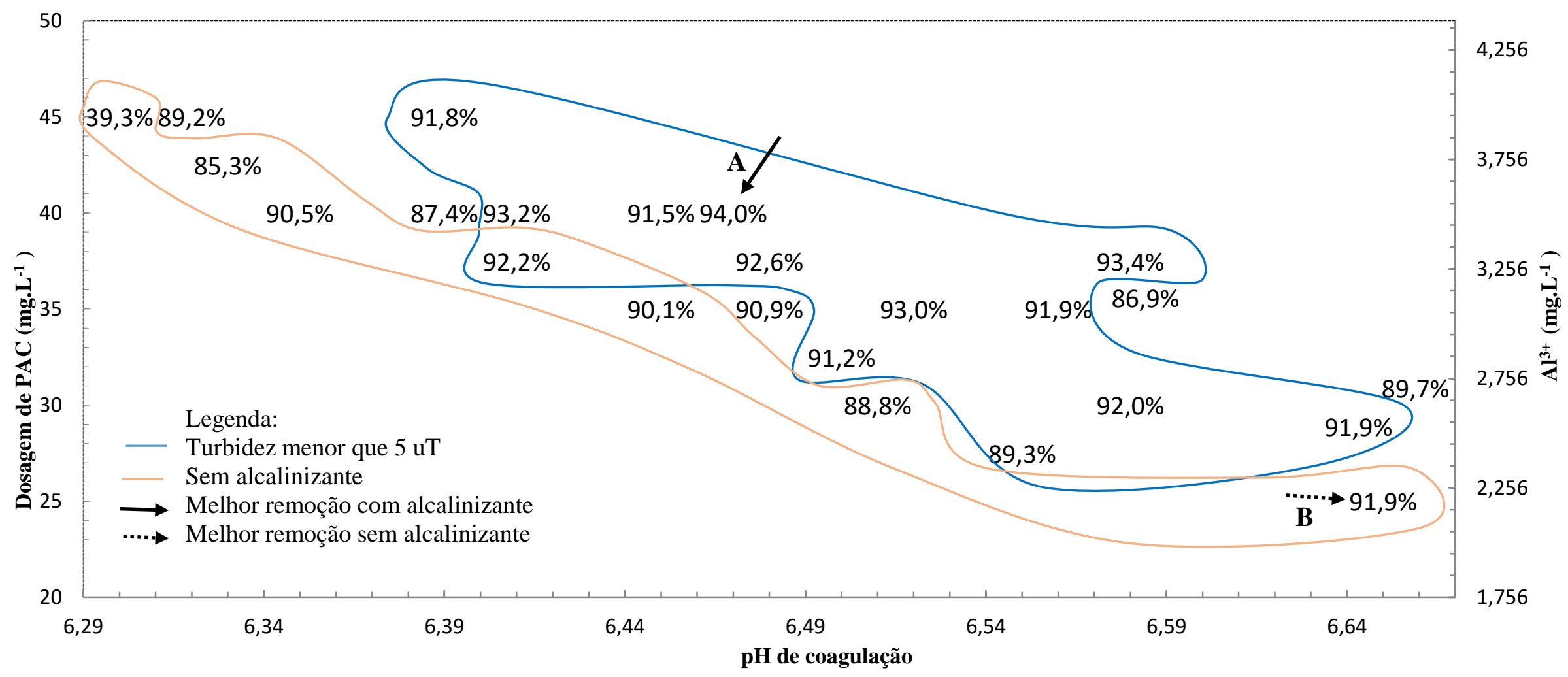

Figura 14: Diagrama de coagulação para turbidez nas seguintes condições: dosagem de PAC entre 25 e $45 \mathrm{mg} \cdot \mathrm{L}^{-1}, \mathrm{G}_{\mathrm{mr}}=700 \mathrm{~s}{ }^{-1}, \mathrm{~T}_{\mathrm{mr}}=15 \mathrm{~s}, \mathrm{G}_{\mathrm{ml}}$ $=50 \mathrm{~s}^{-1}, \mathrm{~T}_{\mathrm{ml}}: 4 \mathrm{~min}$, tempo de flotação $=5 \mathrm{~min}$, taxa de recirculação $=5 \%$ e pressão de saturação $=5$ bar. 


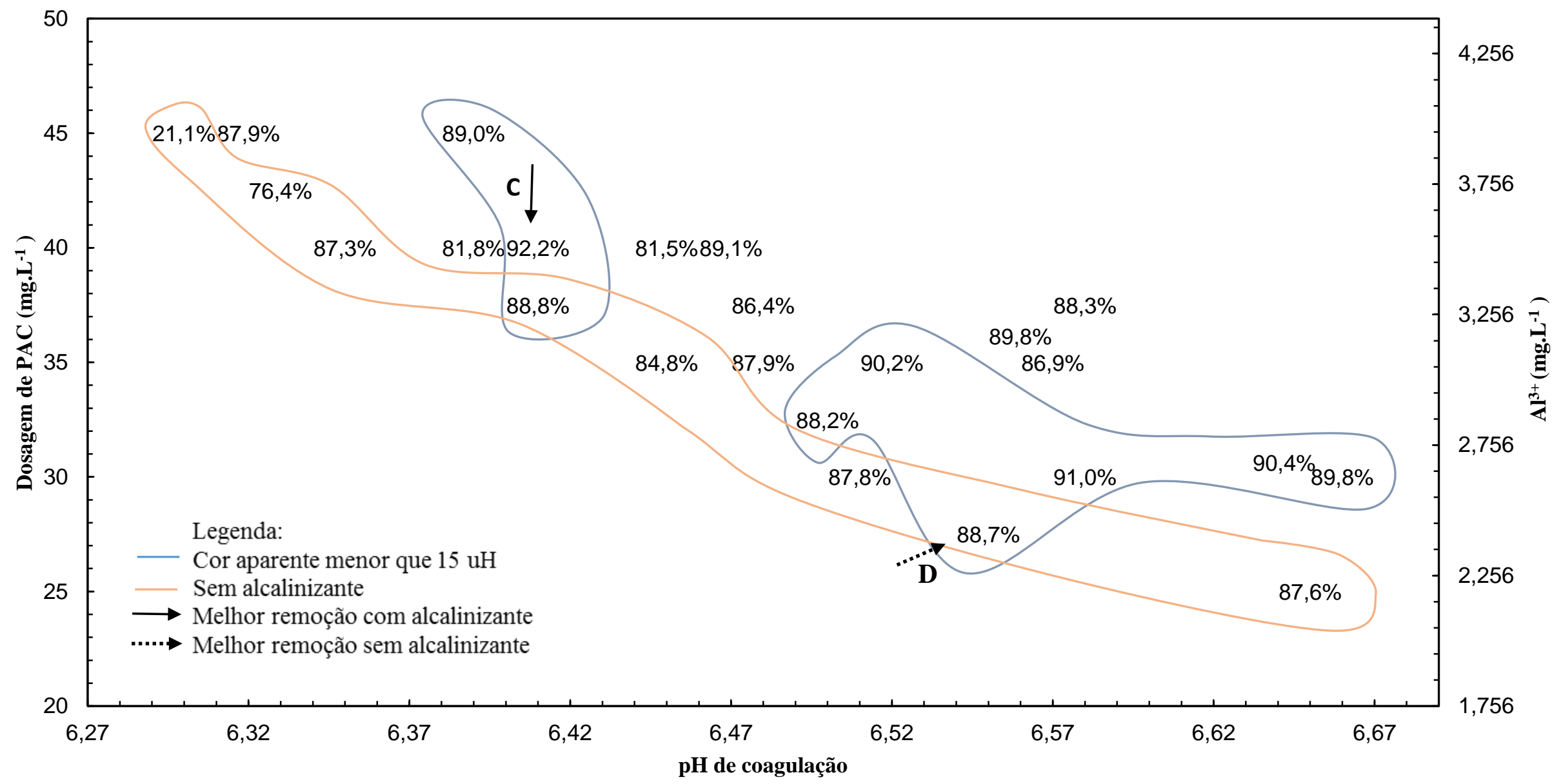

Figura 15: Diagrama de coagulação para cor aparente nas seguintes condições: dosagem de PAC entre 25 e $45 \mathrm{mg} \cdot \mathrm{L}^{-1}, \mathrm{G}_{\mathrm{mr}}=700 \mathrm{~s}^{-1}, \mathrm{~T}_{\mathrm{mr}}=15 \mathrm{~s}$, $\mathrm{G}_{\mathrm{ml}}=50 \mathrm{~s}^{-1}, \mathrm{~T}_{\mathrm{ml}}: 4 \mathrm{~min}$, tempo de flotação $=5 \mathrm{~min}$, taxa de recirculação $=5 \%$ e pressão de saturação $=5$ bar. 
Observando os diagramas de coagulação é possível destacar as melhores dosagens, denominados de "pontos ótimos" apresentados na Tabela 8.

Tabela 8: Melhores valores obtidos a partir do diagrama de coagulação.

\begin{tabular}{ccccc}
\hline Ponto & $\begin{array}{c}\text { Concentração } \\
\text { de PAC } \\
\left(\mathrm{mg} \cdot \mathrm{L}^{-1}\right)\end{array}$ & $\begin{array}{c}\text { Concentração de } \\
\mathrm{Al}^{3+}\left(\mathrm{mg}^{-1}\right)\end{array}$ & $\begin{array}{c}\text { Concentração } \\
\text { de NaOH } \\
\left(\mathrm{mg} \cdot \mathrm{L}^{-1}\right)\end{array}$ & Destaque \\
\hline A & 40 & 3,512 & 15 & $\begin{array}{c}\text { Melhor remoção de } \\
\text { turbidez }\end{array}$ \\
B & 25 & 2,195 & 0 & $\begin{array}{c}\text { Melhor remoção de } \\
\text { turbidez sem } \\
\text { alcalinizante }\end{array}$ \\
C & 40 & 3,512 & 10 & $\begin{array}{c}\text { Melhor remoção de } \\
\text { cor }\end{array}$ \\
D & 27,5 & 2,4145 & 0 & $\begin{array}{c}\text { Melhor remoção de } \\
\text { cor sem alcalinizante }\end{array}$ \\
\hline
\end{tabular}

Os melhores resultados obtidos estão apresentados na Tabela 8. O critério para a escolha do "ponto ótimo" foi pelo ponto que apresentou melhor eficiência de remoção, sem a utilização do alcalinizante e que utilizou a menor dosagem de coagulante, por ser economicamente viável e acessível para sistemas em escala plena. Então, o ponto B foi selecionado e definiu-se a dosagem de $25 \mathrm{mg} . \mathrm{L}^{-1}$ de PAC, que possuía 2,195 mg. $\mathrm{L}^{-1}$ de $\mathrm{Al}^{3+}$ e pH de coagulação de 6,6 para continuar os ensaios. $\mathrm{O}$ valor de $\mathrm{pH}$ de coagulação atendeu ao padrão de potabilidade brasileiro que é na faixa de $6,0 \leq \mathrm{pH} \leq 9,0$, segundo Brasil (2011).

Giglio (2015) também selecionou a dosagem de $25 \mathrm{mg} . \mathrm{L}^{-1}$ de coagulante que corresponde a 2,2 mg. $\mathrm{L}^{-1}$ de $\mathrm{Al}^{+3}$, sem uso de alcalinizante, com $\mathrm{pH}$ de coagulação próximo a 6,7, em ensaios de tratabilidade com sedimentação.

Esta dosagem apresentou, na água clarificada, aproximadamente, valor de turbidez final e de cor aparente de 4 uT e $15 \mathrm{Pt}-\mathrm{Co}$, respectivamente, que, a priori, não atende ao padrão de potabilidade para águas de abastecimento (BRASIL, 2011). No entanto, ao realizar a filtração rápida com os FLAs, última etapa do tratamento de ciclo completo com flotação, verificou-se que os valores de turbidez obtidos eram de 0,1 uT e a cor aparente não era detectada, atendendo, assim, à legislação citada. 


\subsection{Otimização dos Parâmetros do Ensaio de Tratabilidade}

Para realizar os ensaios de tratabilidade, os parâmetros da Tabela 7 foram fixados. As metodologias de Edzwald e Haarhoff (2011) e Di Bernardo, Dantas e Voltan (2011) foram utilizadas para otimizar os parâmetros.

Para a mistura rápida $\left(\mathrm{G}_{\mathrm{mr}}\right.$ : gradiente de mistura rápida e $\mathrm{T}_{\mathrm{mr}}$ : tempo de mistura rápida) foram avaliadas as seguintes condições: i) $\mathrm{G}_{\mathrm{mr}}=600,700,800,900$ e $1000 \mathrm{~s}^{-1}$; e ii) $\mathrm{T}_{\mathrm{mr}}=5,10,15$ e $20 \mathrm{~s}$. Em seguida, os ensaios visaram otimizar a mistura lenta $\left(\mathrm{G}_{\mathrm{ml}}\right.$ : gradiente de mistura lenta e $\mathrm{T}_{\mathrm{ml}}$ : tempo de mistura lenta), e as condições avaliadas foram: i) $\mathrm{G}_{\mathrm{ml}}=30,40,50,60$ e $80 \mathrm{~s}^{-1}$; e ii) $\mathrm{T}_{\mathrm{ml}}=1,2,3,4,5,6$ e 8 min. Então, depois de definida as melhores condições de mistura rápida e lenta, otimizou-se o tempo de flotação, assim, os valores testados foram de 2, 3, 7 e $10 \mathrm{~min}$. E por fim, otimizou-se a taxa de recirculação, e os valores avaliados foram: 5, 10, 15 e $20 \%$. Estes parâmetros foram utilizados e ajustados de acordo com a otimização em cada etapa do ensaio.

\subsubsection{Otimização da Mistura Rápida}

Ensaios com gradientes de mistura rápida de 600,700, 800, 900 e $1000 \mathrm{~s}^{-1}$, foram realizados (Figuras 16 e 17). Os gradientes de 700 e $800 \mathrm{~s}^{-1}$ indicaram os melhores resultados para a redução de turbidez, sendo que o primeiro também obteve melhor redução de cor aparente. Assim, foi definido como gradiente de mistura rápida o valor de $700 \mathrm{~s}^{-1}$ nos ensaios seguintes. 


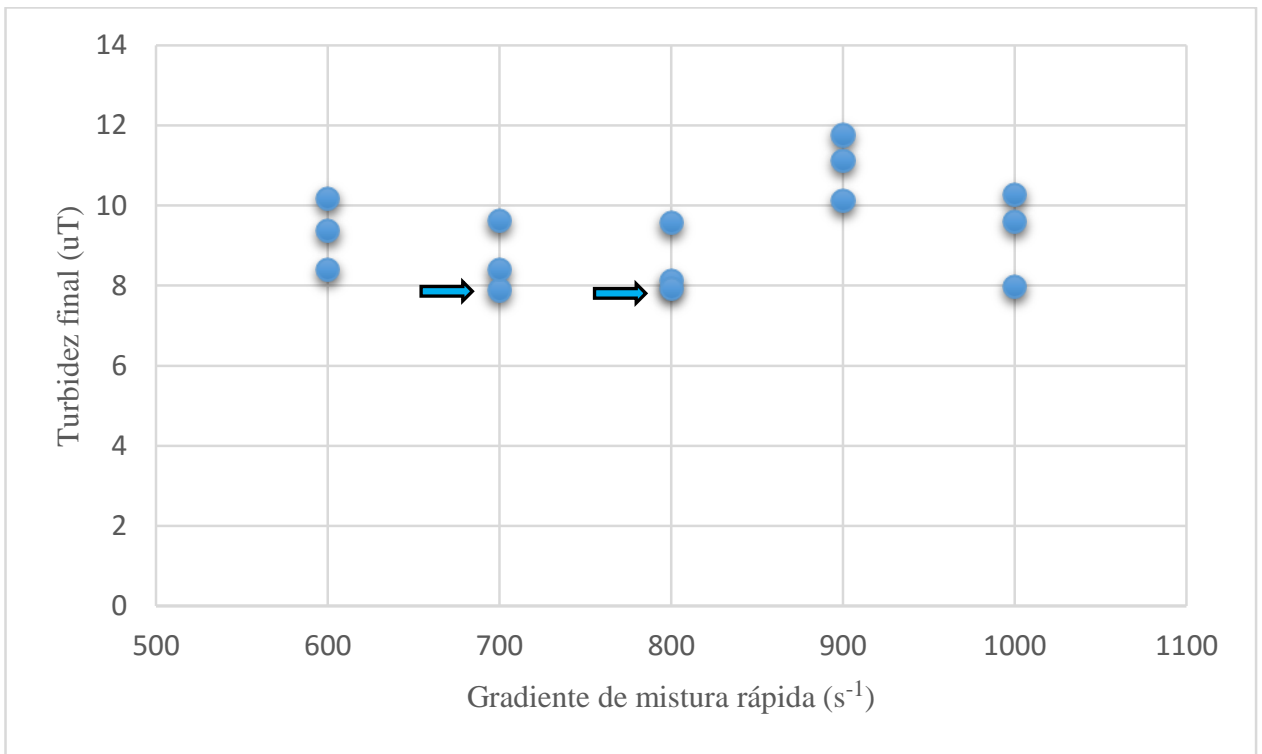

Figura 16: Otimização do gradiente de mistura rápida conforme valores de turbidez remanescente. Ensaios realizados nas seguintes condições: Dosagem de PAC: 25 mg.L ${ }^{-}$ ${ }^{1}, \mathrm{G}_{\mathrm{mr}}$ entre 600 e $1000 \mathrm{~s}^{-1}, \mathrm{~T}_{\mathrm{mr}}=15 \mathrm{~s}, \mathrm{G}_{\mathrm{ml}}=50 \mathrm{~s}^{-1}, \mathrm{~T}_{\mathrm{ml}}=4 \mathrm{~min}, \mathrm{~T}_{\mathrm{flot}}=5 \mathrm{~min}$, taxa de recirculação $=5 \%$, pressão de saturação $=5$ bar. Ensaios em triplicata.

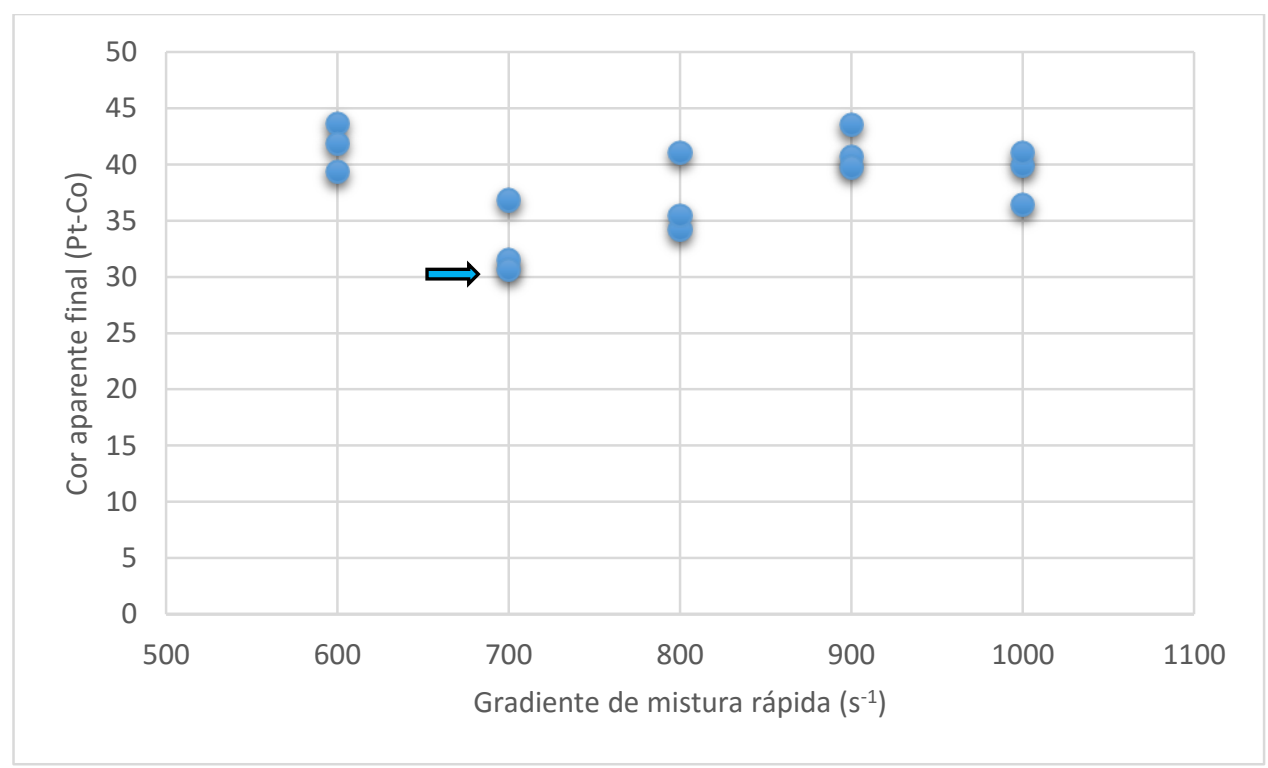

Figura 17: Otimização do gradiente de mistura rápida conforme valores de cor aparente remanescente. Ensaios realizados nas seguintes condições: Dosagem de PAC: 25 mg.L${ }^{1}, \mathrm{G}_{\mathrm{mr}}$ entre 600 e $1000 \mathrm{~s}^{-1}, \mathrm{~T}_{\mathrm{mr}}=15 \mathrm{~s}, \mathrm{G}_{\mathrm{ml}}=50 \mathrm{~s}^{-1}, \mathrm{~T}_{\mathrm{ml}}=4 \mathrm{~min}, \mathrm{~T}_{\mathrm{flot}}=5 \mathrm{~min}$, taxa de recirculação $=5 \%$, pressão de saturação $=5$ bar. Ensaios em triplicata. 
Ao otimizar o gradiente, vários tempos de mistura rápida foram testados (Figuras 18 e 19) e ao avaliar os resultados, o tempo de $10 \mathrm{~s}$ foi selecionado.

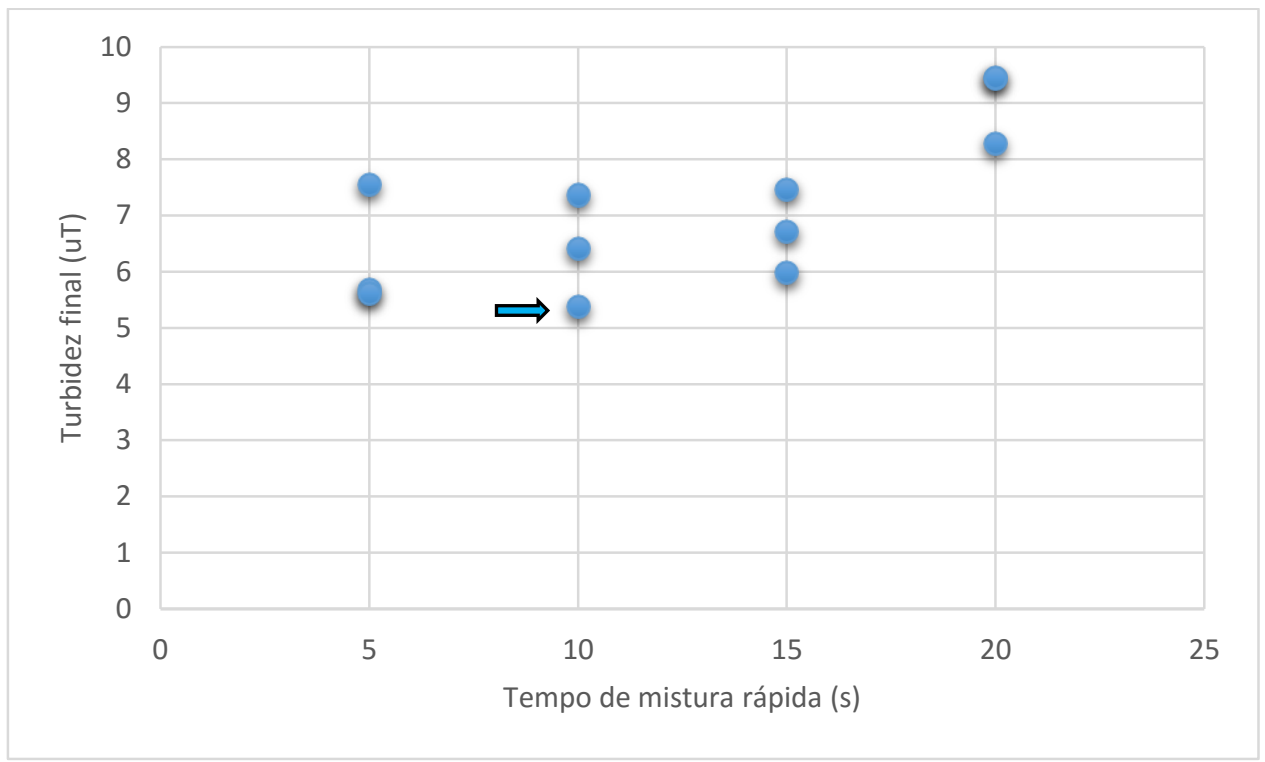

Figura 18: Otimização do tempo de mistura rápida conforme valores de turbidez remanescente. Ensaios realizados nas seguintes condições: Dosagem de PAC: 25 mg.L ${ }^{1}, \mathrm{G}_{\mathrm{mr}}=700 \mathrm{~s}^{-1}, \mathrm{~T}_{\mathrm{mr}}$ entre 5 e $20 \mathrm{~s}, \mathrm{G}_{\mathrm{ml}}=50 \mathrm{~s}^{-1}, \mathrm{~T}_{\mathrm{ml}}=4 \mathrm{~min}, \mathrm{~T}_{\text {flot }}=5 \mathrm{~min}$, taxa de recirculação $=5 \%$, pressão de saturação $=5$ bar. Ensaios em triplicata.

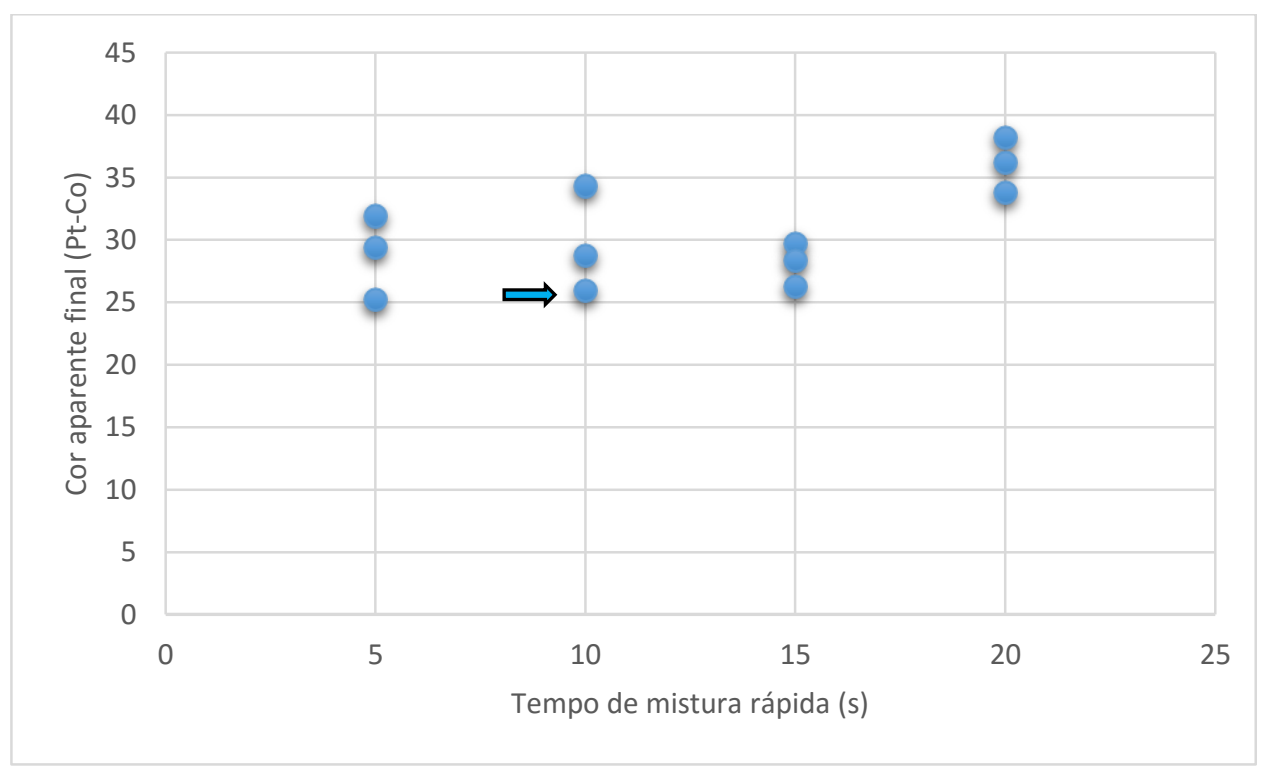

Figura 19: Otimização do tempo de mistura rápida conforme valores de cor aparente remanescente. Ensaios realizados nas seguintes condições: Dosagem de PAC: 25 mg.L ${ }^{-}$ ${ }^{1}, \mathrm{G}_{\mathrm{mr}}=700 \mathrm{~s}^{-1}, \mathrm{~T}_{\mathrm{mr}}$ entre 5 e $20 \mathrm{~s}, \mathrm{G}_{\mathrm{ml}}=50 \mathrm{~s}^{-1}, \mathrm{~T}_{\mathrm{ml}}=4 \mathrm{~min}, \mathrm{~T}_{\text {flot }}=5 \mathrm{~min}$, taxa de recirculação $=5 \%$, pressão de saturação $=5$ bar. Ensaios em triplicata. 


\subsubsection{Otimização da Mistura Lenta}

As Figuras 20 e 21 apresentam os dados obtidos para turbidez e cor aparente.

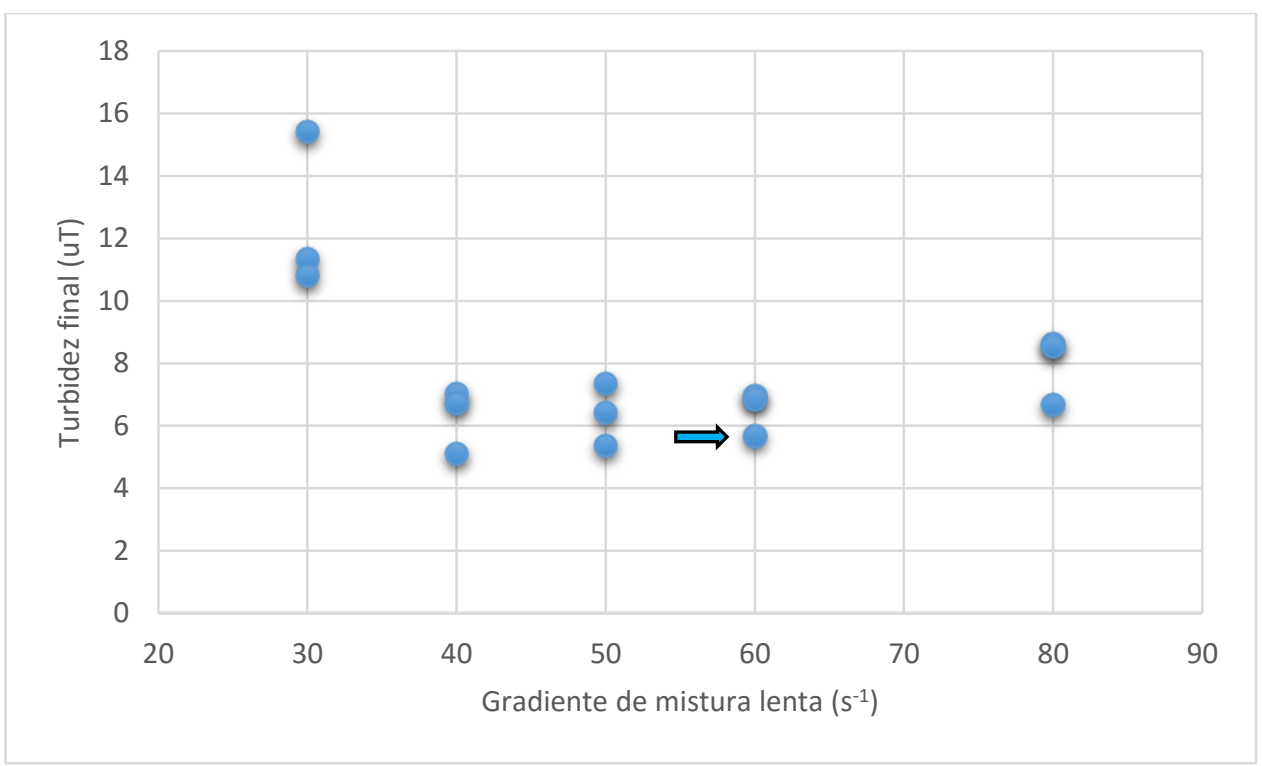

Figura 20: Otimização do gradiente de mistura lenta conforme valores de turbidez remanescente. Ensaios realizados nas seguintes condições: Dosagem de PAC: 25 mg.L1, $\mathrm{G}_{\mathrm{mr}}=700 \mathrm{~s}^{-1}, \mathrm{~T}_{\mathrm{mr}}=10 \mathrm{~s}, \mathrm{G}_{\mathrm{ml}}$ entre 30 e $80 \mathrm{~s}^{-1}, \mathrm{~T}_{\mathrm{ml}}=4 \mathrm{~min}, \mathrm{~T}_{\mathrm{flot}}=5 \mathrm{~min}$, taxa de recirculação $=5 \%$, pressão de saturação $=5$ bar. Ensaios em triplicata.

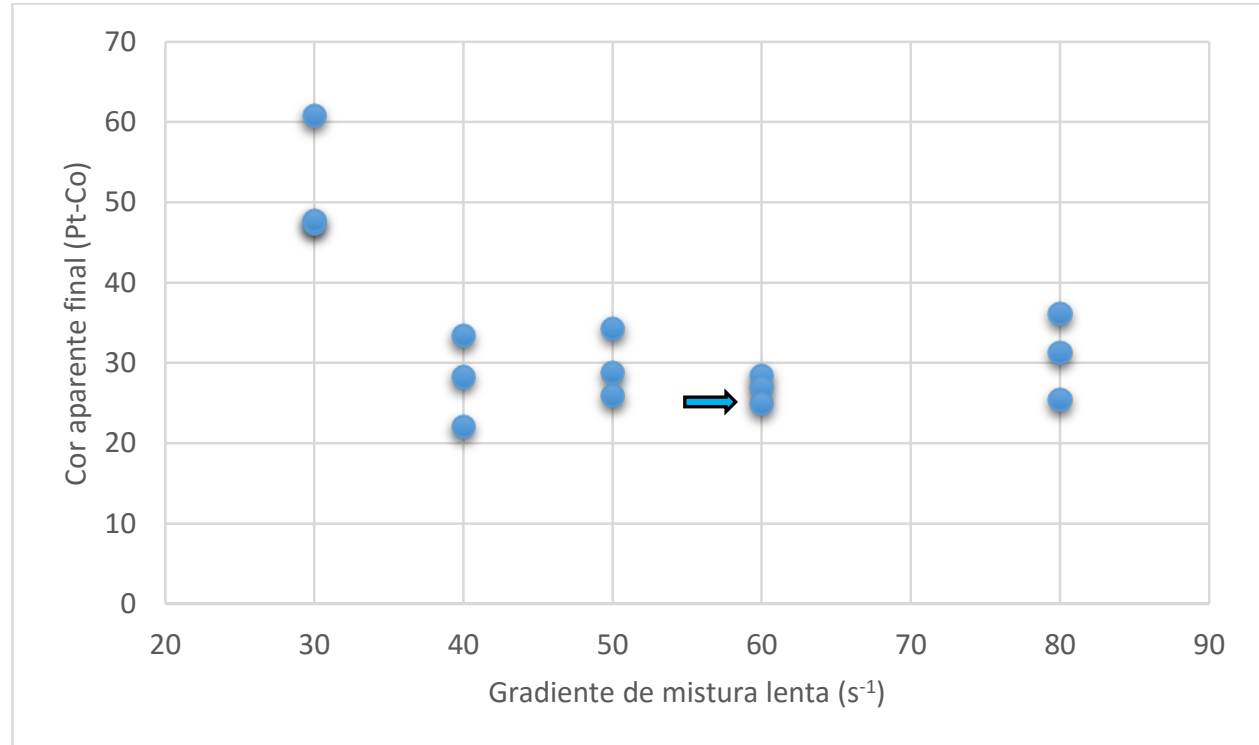

Figura 21: Otimização do gradiente de mistura lenta conforme valores de cor aparente remanescente. Ensaios realizados nas seguintes condições: Dosagem de PAC: 25 mg.L${ }^{1}, \mathrm{G}_{\mathrm{mr}}=700 \mathrm{~s}^{-1}, \mathrm{~T}_{\mathrm{mr}}=10 \mathrm{~s}, \mathrm{G}_{\mathrm{ml}}$ entre 30 e $80 \mathrm{~s}^{-1}, \mathrm{~T}_{\mathrm{ml}}=4 \mathrm{~min}, \mathrm{~T}_{\mathrm{flot}}=5 \mathrm{~min}$, taxa de recirculação $=5 \%$, pressão de saturação $=5$ bar. Ensaios em triplicata. 
Nas Figuras 20 e 21 nota-se que o valor de $\mathrm{G}_{\mathrm{ml}}$ de $40 \mathrm{~s}^{-1}$ apresentou as melhores remoções, porém, somente para um dos três jarros do floteste. Portanto, o gradiente selecionado foi $60 \mathrm{~s}^{-1}$ por também apresentar remoções baixas e com menores alterações entre os jarros.

Plummer, Edzwald e Kelley (1995) indicaram que a turbidez da água diminui ligeiramente com o aumento do gradiente de floculação, pois gera flocos mais fortes, que são removidos facilmente por flotação.

As Figuras 22 e 23 apresentam os dados associados ao tempo de floculação. O tempo de 4 min foi selecionado para os ensaios seguintes.

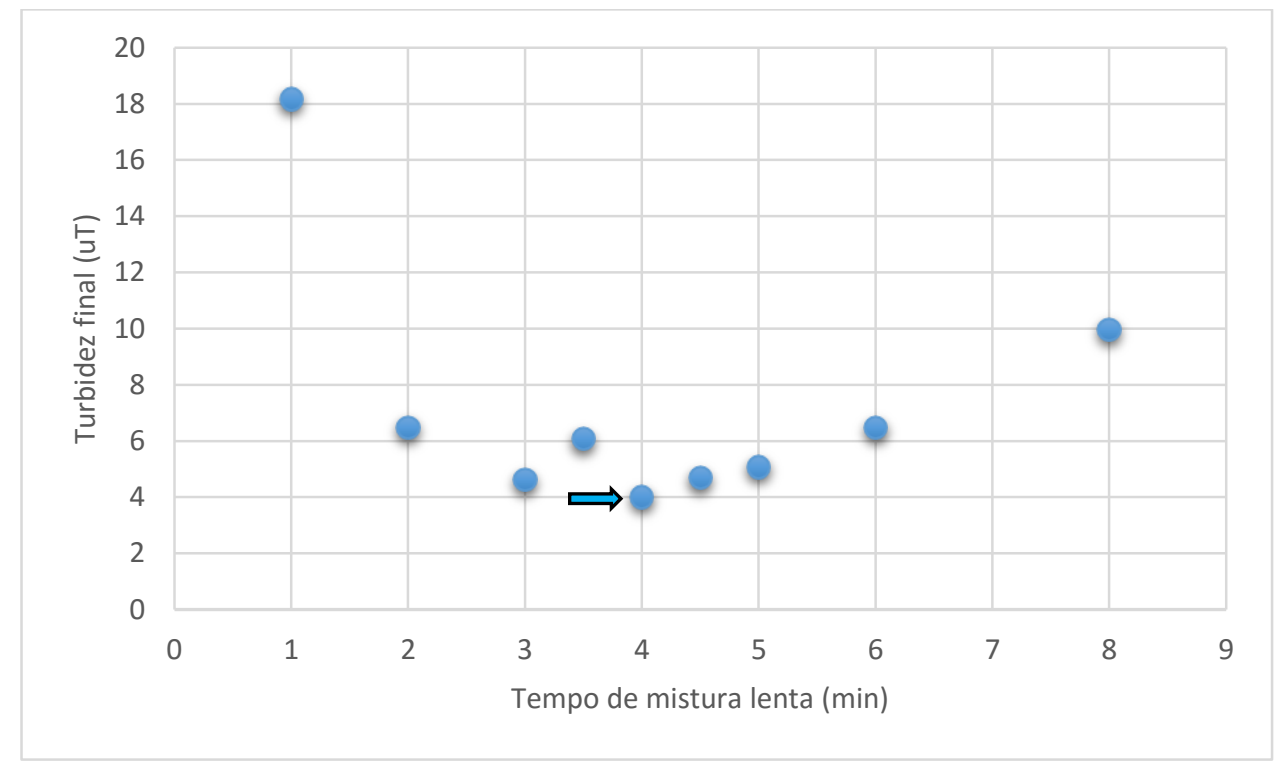

Figura 22: Otimização do tempo de mistura lenta conforme valores de turbidez remanescente. Ensaios realizados nas seguintes condições: Dosagem de PAC: 25 mg.L ${ }^{-}$ ${ }^{1}, \mathrm{G}_{\mathrm{mr}}=700 \mathrm{~s}^{-1}, \mathrm{~T}_{\mathrm{mr}}=10 \mathrm{~s}, \mathrm{G}_{\mathrm{ml}}=60 \mathrm{~s}^{-1}, \mathrm{~T}_{\mathrm{ml}}$ entre 1 e $8 \mathrm{~min}, \mathrm{~T}_{\text {flot }}=5 \mathrm{~min}$, taxa de recirculação $=5 \%$, pressão de saturação $=5$ bar. Ensaios em triplicata. 


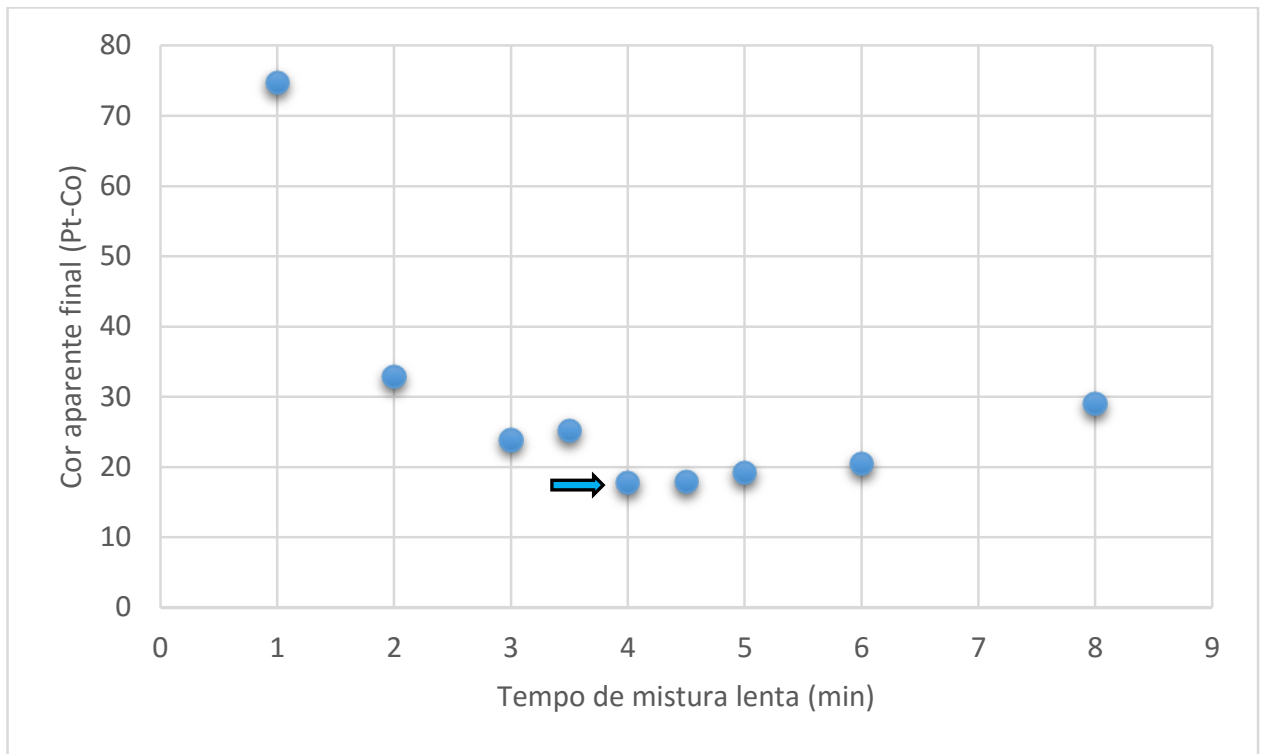

Figura 23: Otimização do tempo de mistura lenta conforme valores de cor aparente remanescente. Ensaios realizados nas seguintes condições: Dosagem de PAC: 25 mg.L ${ }^{-}$ ${ }^{1}, \mathrm{G}_{\mathrm{mr}}=700 \mathrm{~s}^{-1}, \mathrm{~T}_{\mathrm{mr}}=10 \mathrm{~s}, \mathrm{G}_{\mathrm{ml}}=60 \mathrm{~s}^{-1}, \mathrm{~T}_{\mathrm{ml}}$ entre 1 e $8 \mathrm{~min}, \mathrm{~T}_{\text {flot }}=5 \mathrm{~min}$, taxa de recirculação $=5 \%$, pressão de saturação $=5$ bar. Ensaios em triplicata.

Nas Figuras 22 e 23, nota-se que o tempo para a mistura lenta de 4 min foi o mais eficiente, assim, fixou-se este valor. Edzwald et al., (1992) realizaram experimentos em escala de bancada utilizando água de abastecimento, que possuía turbidez de 2,73 NTU, cor de 25 Pt-Co e concentração de COT de 3 - 5 mg.L.-1 e os ensaios com FAD, os tempos de floculação foram fixados em 5, 10 e $20 \mathrm{~min}$. Os pesquisadores demonstraram que períodos longos de floculação não são adequados para a flotação.

Malley e Edzwald (1991) em estudo de comparação entre sedimentação e FAD, também reportaram resultados de escala de bancada que mostraram boas performances de FAD com curtos períodos de floculação, onde a FAD conseguiu bom desempenho com tempo de floculação de 5 min.

\subsubsection{Otimização da Flotação}

As Figuras 24 e 25 apresentam os dados obtidos ao otimizar o tempo de flotação. 


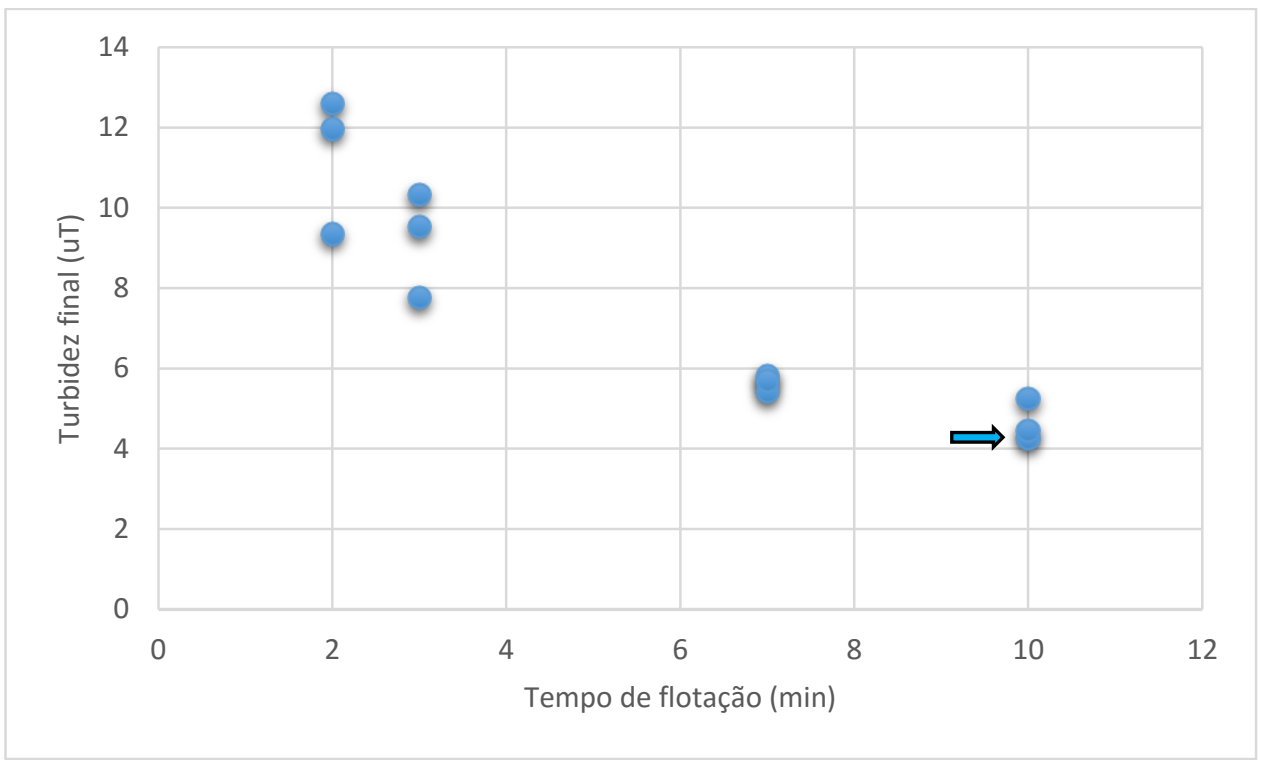

Figura 24: Otimização do tempo de flotação conforme valores de turbidez remanescente. Ensaios realizados nas seguintes condições: Dosagem de PAC: 25 mg.L ${ }^{-}$ ${ }^{1}, \mathrm{G}_{\mathrm{mr}}=700 \mathrm{~s}^{-1}, \mathrm{~T}_{\mathrm{mr}}=10 \mathrm{~s}, \mathrm{G}_{\mathrm{ml}}=60 \mathrm{~s}^{-1}, \mathrm{~T}_{\mathrm{ml}}=4 \mathrm{~min}, \mathrm{~T}_{\text {flot }}$ entre 2 e $10 \mathrm{~min}$, taxa de recirculação $=5 \%$, pressão de saturação $=5$ bar. Ensaios em triplicata.

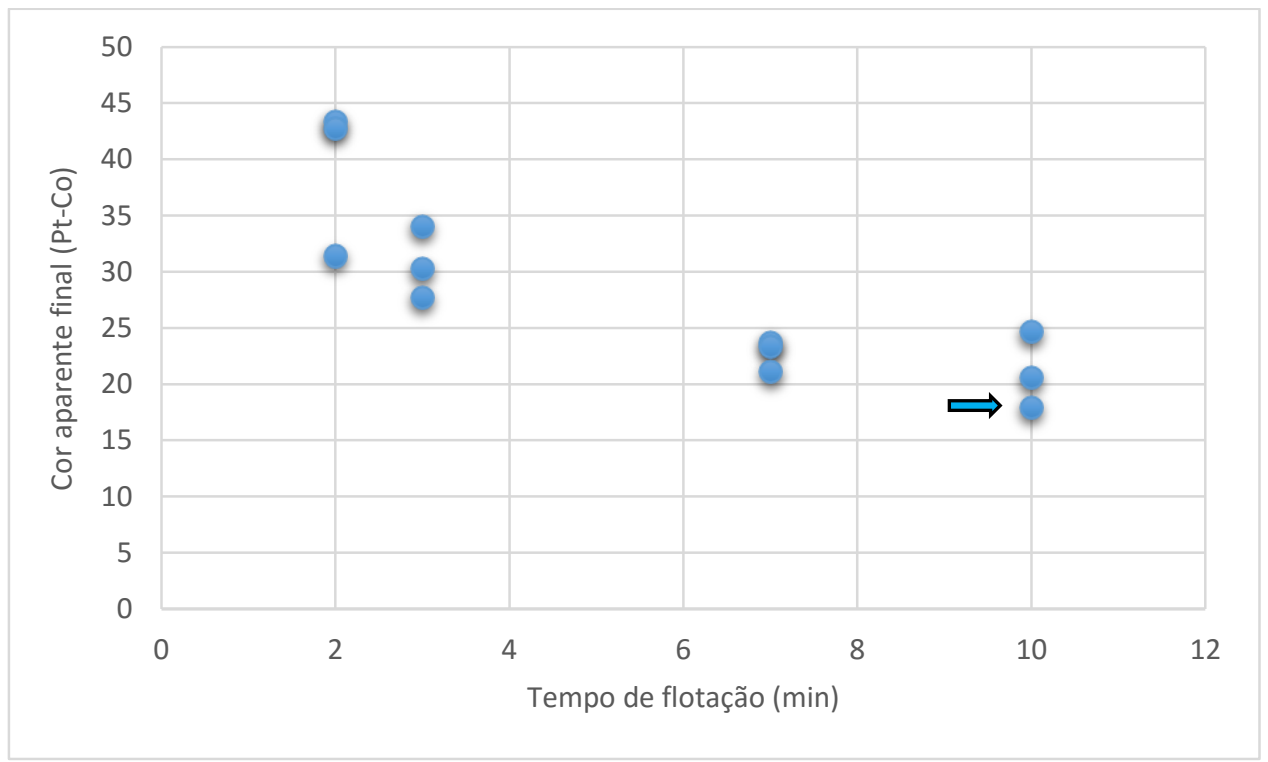

Figura 25: Otimização do tempo de flotação conforme valores de cor aparente remanescente. Ensaios realizados nas seguintes condições: Dosagem de PAC: 25 mg.L ${ }^{-}$ ${ }^{1}, \mathrm{G}_{\mathrm{mr}}=700 \mathrm{~s}^{-1}, \mathrm{~T}_{\mathrm{mr}}=10 \mathrm{~s}, \mathrm{G}_{\mathrm{ml}}=60 \mathrm{~s}^{-1}, \mathrm{~T}_{\mathrm{ml}}=4 \mathrm{~min}, \mathrm{~T}_{\text {flot }}$ entre $2 \mathrm{e} 10 \mathrm{~min}$, taxa de recirculação $=5 \%$, pressão de saturação $=5$ bar. Ensaios em triplicata.

Observa-se que quanto maior o tempo de flotação maior é a remoção de turbidez e cor aparente. Sendo assim, foi fixado o tempo de flotação em $10 \mathrm{~min}$, valor também 
recomendado por Edzwald et al., (1992) e Edzwald e Haarhoff (2011) em escala de bancada com FAD.

\subsubsection{Taxa de Recirculação}

As Figuras 26 e 27 apresentam os dados relacionados à otimização da taxa de recirculação.

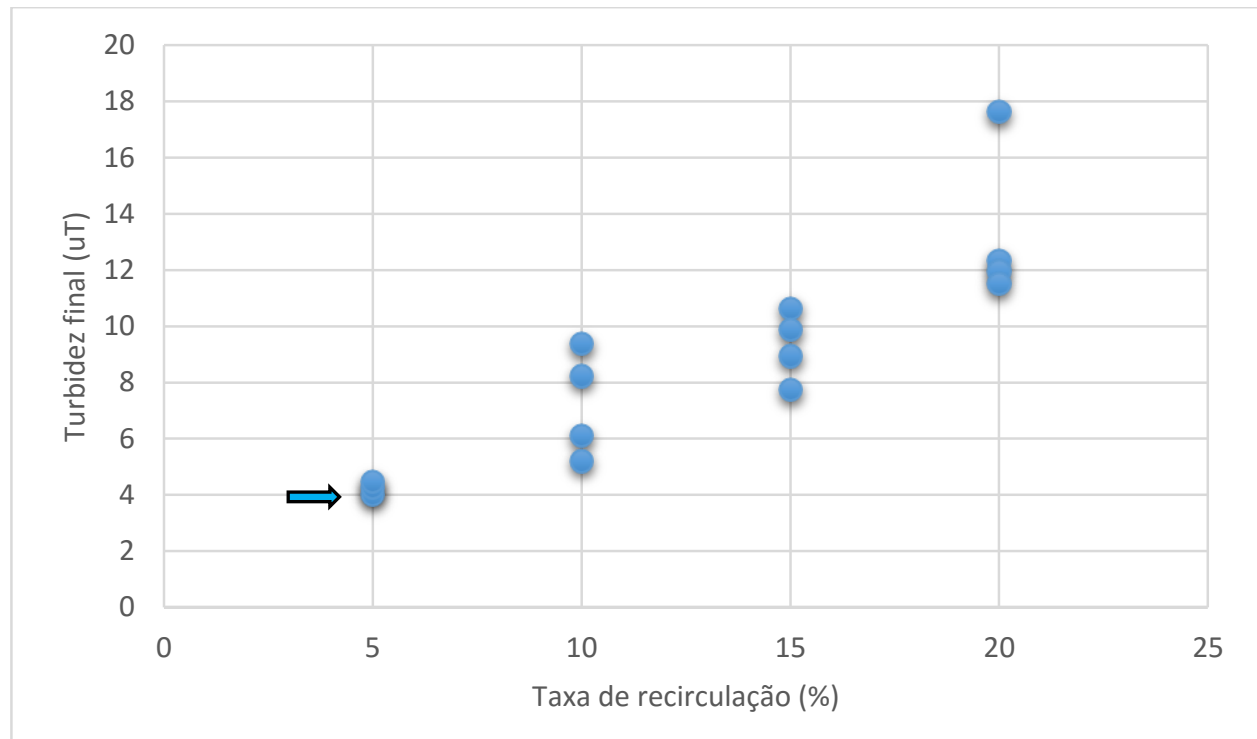

Figura 26: Otimização do tempo de flotação conforme valores de turbidez remanescente. Ensaios realizados nas seguintes condições: Dosagem de PAC: 25 mg.L${ }^{1}, \mathrm{G}_{\mathrm{mr}}=700 \mathrm{~s}^{-1}, \mathrm{~T}_{\mathrm{mr}}=10 \mathrm{~s}, \mathrm{G}_{\mathrm{ml}}=60 \mathrm{~s}^{-1}, \mathrm{~T}_{\mathrm{ml}}=4 \mathrm{~min}, \mathrm{~T}_{\mathrm{flot}}=10 \mathrm{~min}$, taxa de recirculação entre 5 e 20\%, pressão de saturação $=5$ bar. Ensaios em triplicata. 


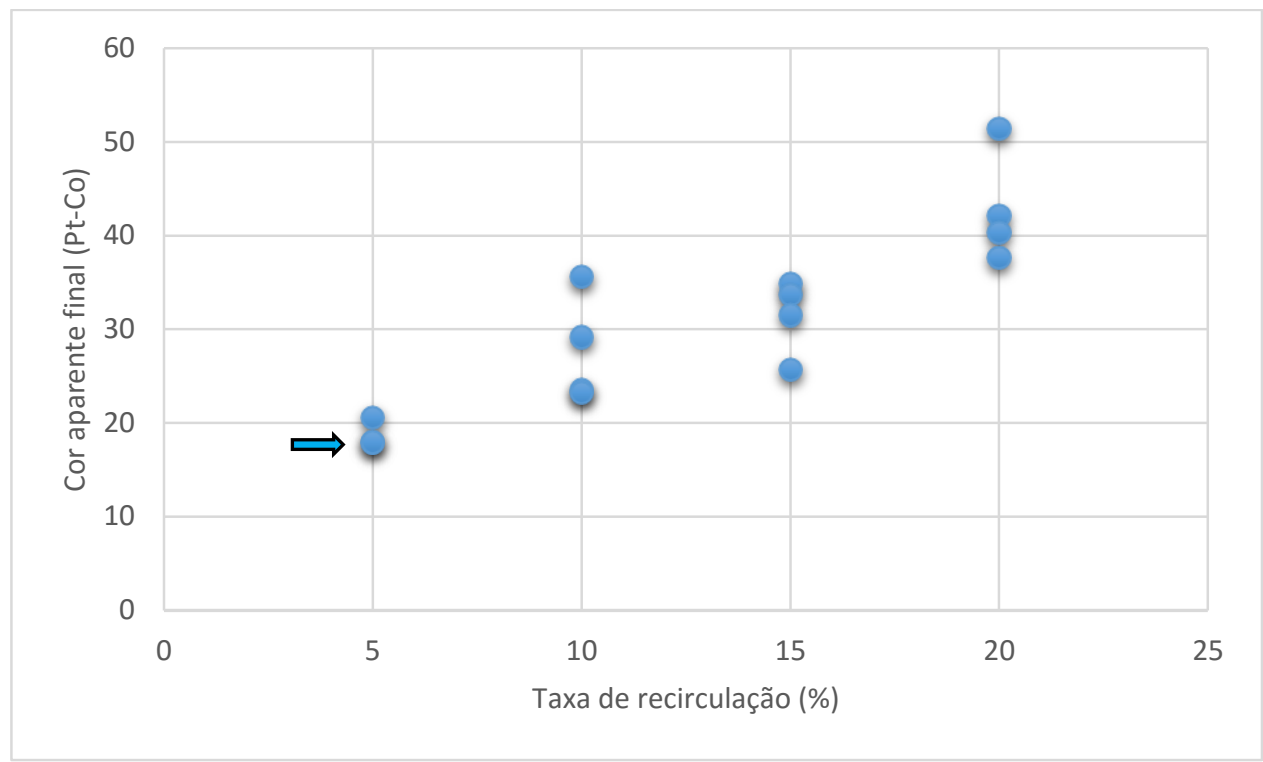

Figura 27: Otimização do tempo de flotação conforme valores de cor aparente remanescente. Ensaios realizados nas seguintes condições: Dosagem de PAC: 25 mg.L ${ }^{-}$ ${ }^{1}, \mathrm{G}_{\mathrm{mr}}=700 \mathrm{~s}^{-1}, \mathrm{~T}_{\mathrm{mr}}=10 \mathrm{~s}, \mathrm{G}_{\mathrm{ml}}=60 \mathrm{~s}^{-1}, \mathrm{~T}_{\mathrm{ml}}=4 \mathrm{~min}, \mathrm{~T}_{\mathrm{flot}}=10 \mathrm{~min}$, taxa de recirculação entre 5 e $20 \%$, pressão de saturação $=5$ bar. Ensaios em triplicata.

Os resultados indicaram que quanto menor a taxa de recirculação maior é a remoção dos parâmetros, assim, foi fixada a taxa de recirculação em 5\%. Di Bernardo, Dantas e Voltam (2011) recomendam que a taxa mínima de recirculação de água saturada com ar seja de 5\%, por ser a menor taxa viável para o aparelho.

\subsubsection{Parâmetros Otimizados}

Os parâmetros associados à coagulação, floculação e flotação foram otimizados e os resultados estão na Tabela 9. 
Tabela 9: Parâmetros definidos após a otimização do tratamento de ciclo-completo com flotação.

\begin{tabular}{lccc}
\hline Parâmetros & Sigla & Unidade & Valor \\
\hline Concentração de caulinita na água de estudo & - & $\mathrm{mg} . \mathrm{L}^{-1}$ & 90 \\
Concentração de ácido húmico na água de estudo & - & $\mathrm{mg} . \mathrm{L}^{-1}$ & 10 \\
Dosagem de coagulante (PAC com 17,56\% de $\left.\mathrm{Al}_{2} \mathrm{O}_{3}\right)$ & - & $\mathrm{mg} . \mathrm{L}^{-1}$ & 25 \\
Gradiente de mistura rápida & $\mathrm{G}_{\mathrm{mr}}$ & $\mathrm{s}^{-1}$ & 700 \\
Tempo de mistura rápida & $\mathrm{T}_{\mathrm{mr}}$ & $\mathrm{s}$ & 10 \\
Gradiente de mistura lenta & $\mathrm{G}_{\mathrm{ml}}$ & $\mathrm{s}^{-1}$ & 60 \\
Tempo de mistura lenta & $\mathrm{T}_{\mathrm{ml}}$ & $\mathrm{min}$ & 4 \\
Tempo de flotação & $\mathrm{T}_{\mathrm{flot}}$ & $\mathrm{min}$ & 10 \\
Taxa de recirculação & $\mathrm{T}_{\mathrm{rec}}$ & $\%$ & 5 \\
Pressão de saturação & $\mathrm{P}_{\mathrm{sat}}$ & bar & 5
\end{tabular}

\subsubsection{Curva de Flotação}

O ensaio para obter a curva foi realizado em triplicata para minimizar os possíveis erros, contudo, as colunas tiveram desempenhos diferentes, por isso foi escolhida a melhor coluna para realização da curva de flotação.

O gráfico foi obtido no floteste de coluna com os dados da Tabela 9, utilizando o mesmo volume dos jarros, 2 L e as curvas estão apresentadas nas Figuras 28 e 29.

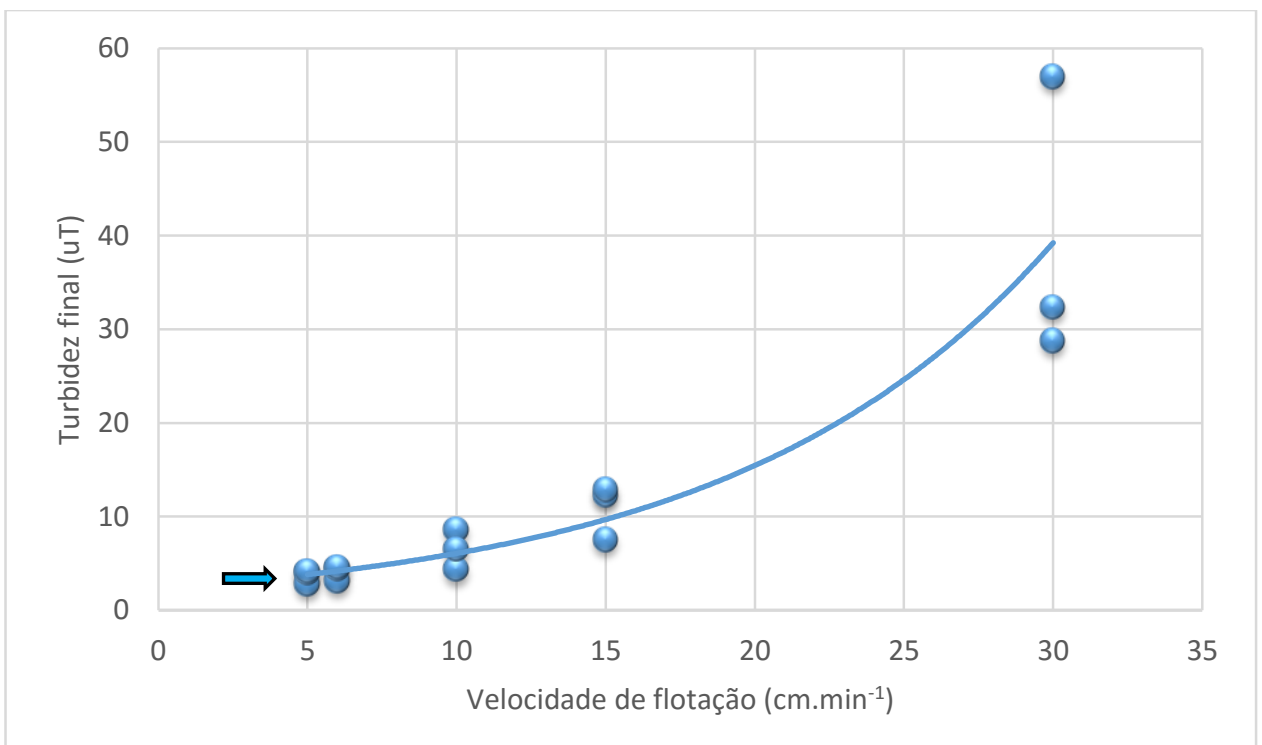

Figura 28: Curva de flotação para turbidez. Ensaio em triplicata. 


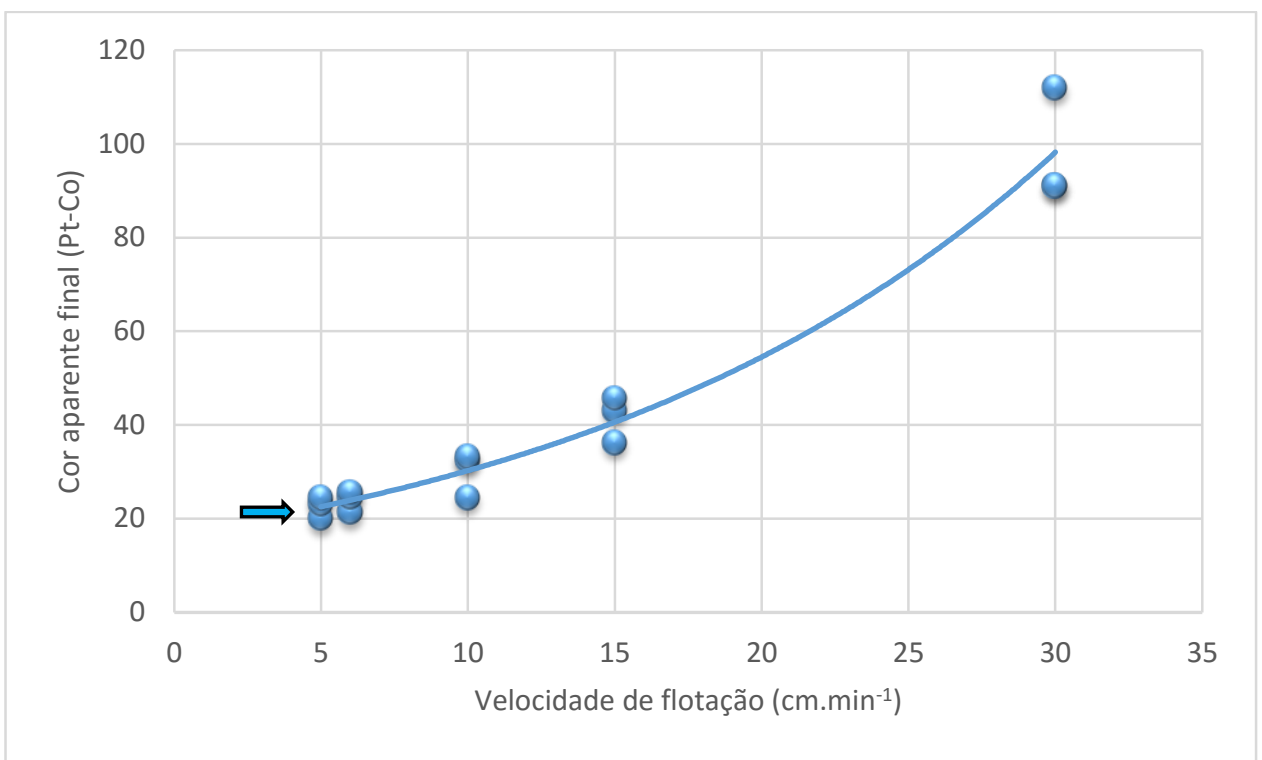

Figura 29: Curva de flotação para cor aparente. Ensaio em triplicata.

No ensaio com o melhor desempenho, a velocidade de flotação utilizada foi de 5 $\mathrm{cm} \mathrm{min}^{-1}$, como pode ser observado nas Figuras 28 e 29. Este resultado foi similar às curvas de flotação obtidas por Reali, Moruzzi e Patrizzi (2003) em estudo da FAD aplicado na clarificação de águas com picos altos de turbidez.

\subsubsection{Características da Água Filtrada Após Otimizar os Parâmetros de Tratabilidade}

Os resultados obtidos após aplicar os parâmetros otimizados à água de estudo estão apresentados na Tabela 10.

Tabela 10: Características da turbidez e da cor ao longo do tratamento.

\begin{tabular}{lccc}
\hline Jarro do Floteste & 1 & 2 & 3 \\
\hline Turbidez inicial (uT) & 53,3 & 53,3 & 53,3 \\
Cor aparente inicial (Pt-Co) & 159 & 159 & 159 \\
Turbidez da água flotada (uT) * & 5,082 & 4,431 & 5,061 \\
Cor aparente da água flotada (Pt-Co) * & 22,89 & 22,57 & 24,36 \\
Remoção de turbidez (\%) & 90,47 & 91,69 & 90,5 \\
Remoção de Cor (\%) & 85,6 & 85,8 & 84,68 \\
\hline
\end{tabular}

Nota: $*$ = Valores corrigidos. 
Os valores da turbidez e da cor aparente final foram corrigidos devido à água saturada que entra nos jarros no processo de flotação e pode ser calculado segundo Di Bernardo, Dantan e Voltam (2011), pela Equação 19:

$$
T R=\frac{V_{R}}{2000}
$$

Em que:

$\mathrm{T}_{\mathrm{R}}=$ Taxa de recirculação $(\%)$;

$\mathrm{V}_{\mathrm{R}}=$ Volume de água de circulação $(\mathrm{mL})$.

No ensaio a $\mathrm{T}_{\mathrm{R}}$ era 5\%, então um volume de $100 \mathrm{~mL}$ de água saturada com ar era introduzido no jarro.

Observa-se na Tabela 10, que os valores apresentados não atenderam à Portaria MS no 2914/2011. Portanto, para finalizar, um último ensaio de tratabilidade da água de estudo foi realizado para avaliar o desempenho da filtração utilizando filtros de areia de laboratório - FLAs com taxa de filtração de $\pm 20 \mathrm{~mL} / \mathrm{min}\left( \pm 100 \mathrm{~m}^{3} / \mathrm{m}^{2}\right.$ dia $)$, os resultados estão apresentados na Tabela 11.

Tabela 11: Características da água filtrada.

\begin{tabular}{ccccc}
\hline & $\begin{array}{c}\text { Características da amostra após 10 } \\
\text { min de filtração }\end{array}$ & \multicolumn{2}{c}{$\begin{array}{c}\text { Características da amostra após 20 min } \\
\text { de filtração }\end{array}$} \\
\hline Jarro & $\begin{array}{c}\text { Cor Aparente } \\
\text { (Pt-Co) }\end{array}$ & Turbidez (uT) & $\begin{array}{c}\text { Cor Aparente } \\
\text { (Pt-Co) }\end{array}$ & Turbidez (uT) \\
\hline 1 & 0 & 0,128 & 0 & 0,226 \\
2 & 0 & 0,155 & 0 & 0,197 \\
3 & 0 & 0,095 & 0 & 0,166 \\
\hline
\end{tabular}

Os valores após o ensaio com filtração atenderam ao padrão de potabilidade supracitado.

\subsection{Teste Iniciais de Estimativa da Viabilidade da Suspensão}

\subsubsection{Avaliação da Estimativa da Viabilidade da Suspensão com Azul de Tripano}




\subsubsection{Resultado do Método 1 AT - Incubação da Suspensão Giardia spp. em Azul de Tripano em Tubo PCR}

No Método 1 AT, foram realizados 2 testes e os resultados obtidos estão expressos em porcentagem de organismos viáveis conforme apresentados na Tabela 12.

Tabela 12: Resultados dos testes 1 e 2 do Método 1 AT.

\begin{tabular}{ccccc}
\hline \multirow{2}{*}{$\begin{array}{c}\text { Giardia } \\
\text { spp. }\end{array}$} & Ensaio & $\begin{array}{c}\text { Inviáveis } \\
\text { (corados) }\end{array}$ & $\begin{array}{c}\text { Viáveis (Não } \\
\text { corados) }\end{array}$ & $\begin{array}{c}\text { \% Organismos } \\
\text { Viáveis }\end{array}$ \\
\cline { 2 - 5 } & 1 & 200 & 600 & 75 \\
\cline { 2 - 5 } & 2 & 600 & 400 & 40 \\
\hline
\end{tabular}

Os valores encontrados na lâmina foram multiplicados pelo FM do azul de tripano e em seguida, um cálculo foi realizado a partir do valor da alíquota (no caso do Método $1 \mathrm{AT}$, de $10 \mu \mathrm{L}$ ) para se conhecer a quantidade de Giardia encontrada em $1 \mathrm{~mL}$ (devido à fórmula da porcentagem ser expressa em $\mathrm{mL}$ ), então calculou-se a porcentagem pela Equação 5 apresentada no item 4.11.1.

Para o ensaio 1, obteve-se $75 \%$ de organismos viáveis em $1 \mathrm{~mL}$ de alíquota e 40 $\%$ para o ensaio 2. Como a quantidade inoculada foi grande, esperava-se que o número de cistos recuperados fosse maior, portanto, alterações foram efetuadas, visando obter melhores resultados.

\subsubsection{Resultado do Método 2 AT - Substituição da Suspensão de Giardia, Aumento do Tempo de Homogeneização, Volume de Inóculo Menor e Aplicação do Corante direto na Lâmina Lisa}

Neste teste, utilizou-se $10 \mu \mathrm{L}$ de alíquota, com incubação direto na lâmina de microscopia e efetuaram-se os mesmos cálculos realizados no Item 5.5.1.1. O ensaio foi realizado quatro vezes, adotando os mesmos valores e nenhum cisto foi encontrado. 


\subsubsection{Resultado do Método 3 AT - Centrifugação da} Suspensão de Giardia lamblia e Repetição do Procedimento Anterior

Devido à ausência de cistos nos ensaios do Item 5.5.1.2, novas alterações foram realizadas, a fim de encontrar os cistos de Giardia lamblia. A suspensão foi concentrada e o procedimento anteriormente citado, foi repetido. Mesmo após a concentração, nenhum cisto foi observado.

\subsubsection{Resultado do Método 4 AT - Nova Contagem da Suspensão Comercial, Realização de uma Nova Centrifugação, Aumento do Inóculo e Incubação feita em Eppendorff}

Visto que os Métodos 2 AT e 3 AT não permitiram encontrar nenhum cisto de Giardia, optou-se por realizar uma nova contagem (Tabela 13) da suspensão para, então, prosseguir com o Método 4 AT.

Tabela 13: Resultado da contagem de Giardia lamblia (5 $\mu \mathrm{L}$ em cada poço) para a realização do Método 4.

\begin{tabular}{lccc}
\hline & \multicolumn{4}{c}{ Poços da Lâmina } \\
\cline { 2 - 4 } Giardia lamblia & 1 & 2 & 3 \\
\cline { 2 - 4 } & 39 & 21 & $129+2$ aglomerados \\
\hline
\end{tabular}

Ao realizar a concentração e contagem da suspensão, o Método 4 AT foi realizado, utilizando $10 \mu \mathrm{L}$ da alíquota para leitura e os cálculos estão na Tabela 14 .

Tabela 14: Resultado do Método 4 AT.

\begin{tabular}{ccccc}
\hline $\begin{array}{l}\text { Giardia } \\
\text { lamblia }\end{array}$ & Ensaio & Corados & Não corados & $\begin{array}{c}\text { \% Organismos viáveis } \\
\text { (não corados) }\end{array}$ \\
\cline { 2 - 5 } & 1 & 1600 & 600 & 27,3 \\
\hline
\end{tabular}


Na Tabela 14, nota-se que, em $1 \mathrm{~mL}$ de alíquota, encontrou-se 1600 cistos de Giardia inviáveis (corados) e 600 cistos viáveis (não corados), totalizando uma porcentagem de $27,3 \%$ de organismos viáveis.

\subsubsection{Resultado do Método 5 AT - Alteração do Volume Incubado e Utilização de Toda a Alíquota Contida no Eppendorff}

Como os resultados ainda não eram satisfatórios, mais uma modificação foi realizada considerando a incubação de todo o volume utilizado, a fim de evitar perdas de protozoários. Apesar das alterações, o Método 5 AT não obteve sucesso, pois os organismos-alvo não foram visualizados.

\subsubsection{Resultado do Método 6 AT - Aumento do Inóculo e Avaliação dos Resultados}

Como o Método 5 AT não obteve resultados favoráveis, algumas alterações foram efetuadas novamente. No Método 6 AT, as suspensões de Giardia lamblia e Cryptosporidium parvum foram avaliadas qualitativamente, ou seja, o uso do azul de tripano foi analisado considerando a dificuldade de leitura no campo claro e a baixa concentração de (oo) cistos e os resultados estão na Tabela 15. 
Tabela 15: Resultado dos testes obtidos para a suspensão de Giardia lamblia e Cryptosporidium parvum.

\begin{tabular}{|c|c|c|c|c|}
\hline Protozoários & Ensaio & $\begin{array}{l}\text { Inviáveis } \\
\text { (corados) }\end{array}$ & $\begin{array}{c}\text { Viáveis } \\
\text { (não corados) }\end{array}$ & $\begin{array}{l}\text { \% Organismos } \\
\text { Viáveis } \\
\text { (não corados) }\end{array}$ \\
\hline \multirow{5}{*}{ Giardia lamblia } & 1 & 3600 & 400 & 5,7 \\
\hline & 2 & 600 & $\mathrm{NE}$ & $\mathrm{NC}$ \\
\hline & 3 & 200 & $\mathrm{NE}$ & $\mathrm{NC}$ \\
\hline & 4 & 800 & $\mathrm{NE}$ & $\mathrm{NC}$ \\
\hline & 5 & 1600 & 600 & 27,3 \\
\hline \multirow{5}{*}{$\begin{array}{c}\text { Cryptosporidium } \\
\text { parvum }\end{array}$} & 1 & 0 & 400 & 100 \\
\hline & 2 & 800 & 1400 & 63,6 \\
\hline & 3 & 800 & 1800 & 69,2 \\
\hline & 4 & 1000 & 1800 & 64,3 \\
\hline & 5 & 800 & 2400 & 75 \\
\hline
\end{tabular}

Nota: $\mathrm{NE}=$ não encontrado e $\mathrm{NC}=$ não calculado

Nos cinco ensaios realizados com a suspensão de Giardia lamblia, nota-se que os valores apresentaram grande variabilidade, na qual, o ensaio 1 obteve 5,7\% de organismos viáveis (não corados) e o ensaio 5, obteve 27,3\%, e ainda, nos ensaios 2, 3 e 4 devido à ausência de cistos viáveis, não foi possível contabilizar a porcentagem.

No caso da suspensão de Cryptosporidium parvum, a porcentagem mínima de organismos viáveis foi no ensaio 2 , com $63,6 \%$ e a máxima encontrada foi no ensaio 1 , com $100 \%$ dos (oo) cistos viáveis.

\subsubsection{Resultado do Método 7 AT - Substituição da Suspensão de Giardia lamblia, Alteração do volume de Inóculo e Incubação Direto na Lâmina}

Por fim, um último método foi testado e a suspensão de Giardia lamblia foi substituída, devido à formação de aglomerados de cistos que impossibilitaram a contagem. 
Os dados de porcentagem de organismos viáveis em $1 \mathrm{~mL}$ de amostra para a suspensão de Giardia spp. e Cryptosporidium parvum (ensaios em triplicata) foram apresentados na Tabela 16.

Tabela 16: Resultado da leitura em triplicata das lâminas de Giardia spp. e Cryptosporidium parvum.

\begin{tabular}{ccccc}
\hline \multirow{2}{*}{$\begin{array}{c}\text { Protozoários } \\
\text { Ensaio }\end{array}$} & $\begin{array}{c}\text { Inviáveis } \\
\text { (corados) }\end{array}$ & $\begin{array}{c}\text { Viáveis (não } \\
\text { corados) }\end{array}$ & $\begin{array}{c}\text { \% Organismos } \\
\text { Viáveis (não } \\
\text { corados) }\end{array}$ \\
\cline { 2 - 5 } Giardia spp. & 1 & 8800 & 3000 & 25,4 \\
\cline { 2 - 5 } & 2 & 12800 & 6400 & 33,3 \\
\hline \multirow{2}{*}{\begin{tabular}{c} 
Cryptosporidium \\
\cline { 2 - 5 } parvum
\end{tabular}} & 1 & 21400 & 2000 & 8,5 \\
\cline { 2 - 5 } & 2 & 1400 & 3600 & 62,0 \\
\hline
\end{tabular}


Na Figura 30, pode-se observar uma imagem da lâmina de Giardia spp. utilizando o azul de tripano, mostrando a diferença do organismo quando penetra ou não o corante e na Figura 31, uma lâmina preparada de Cryptosporidium parvum, com o oocisto viável.

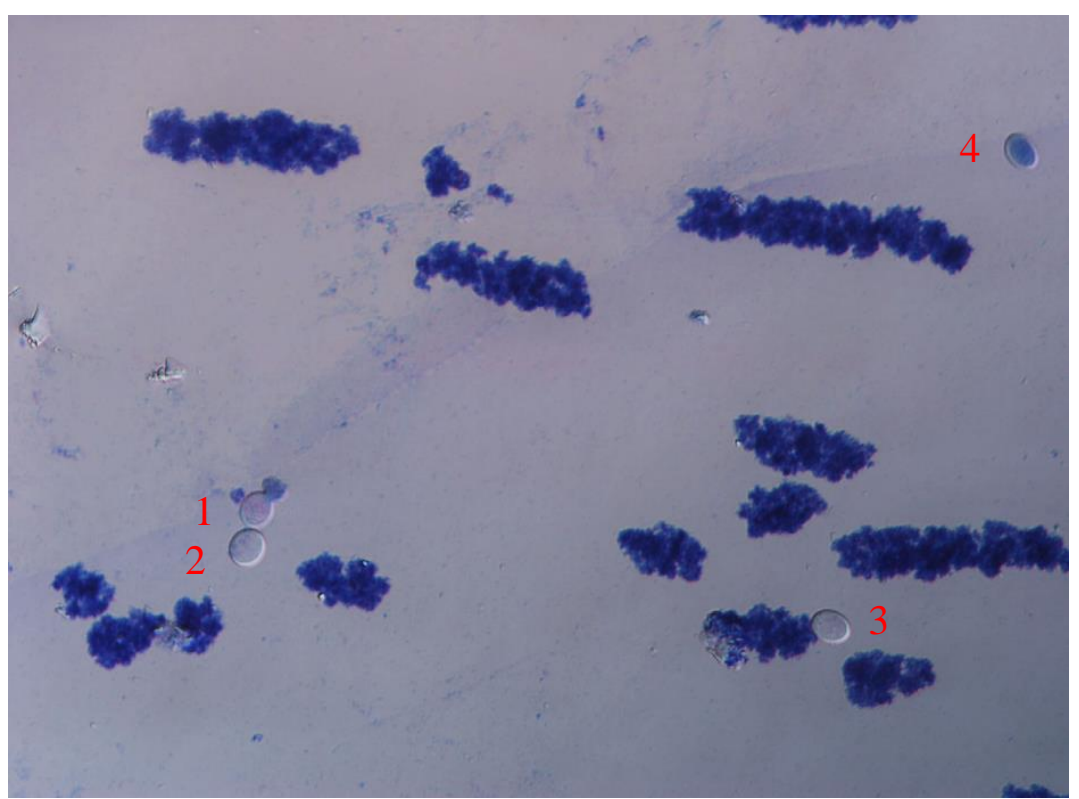

Figura 30: Imagem da lâmina de Giardia spp. com o azul de tripano. 1, 2 e 3: Cistos de Giardia que não penetraram o corante e 4: Cisto de Giardia que penetrou o corante, (aumento de $400 \mathrm{x}$ ).

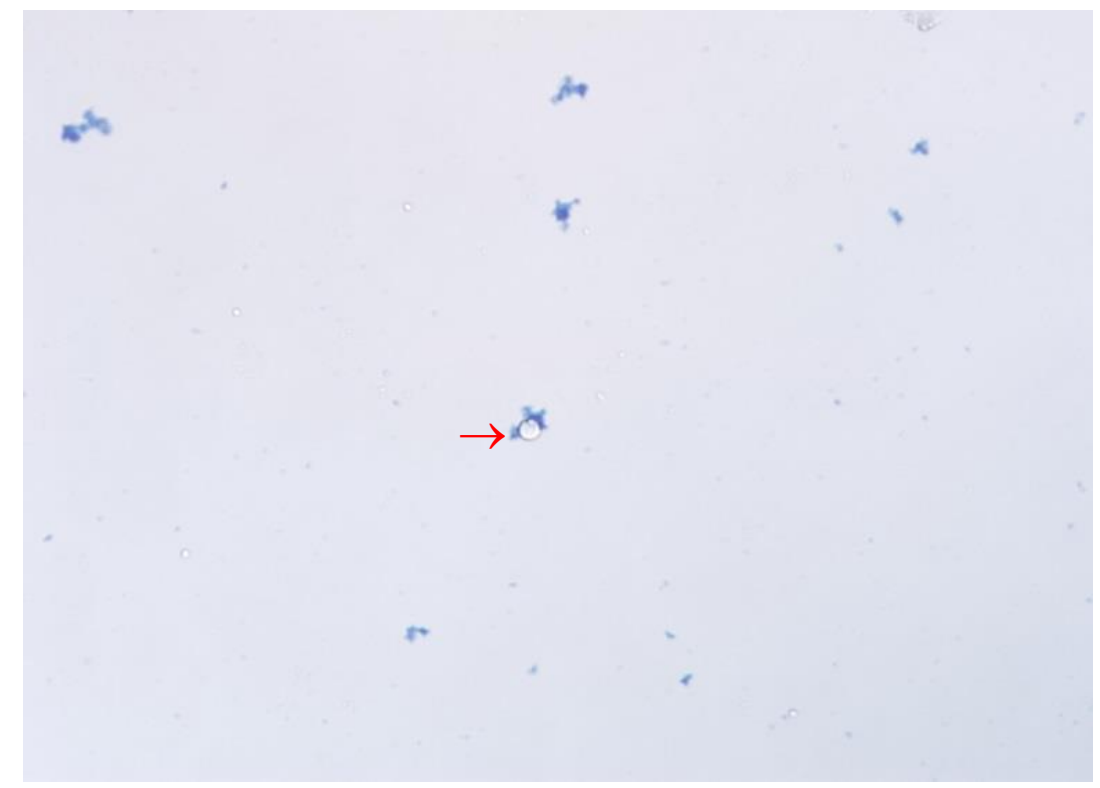

Figura 31: Imagem da lâmina de Cryptosporidium parvum com o azul de tripano, em que o oocisto não penetrou o corante (cisto viável) (Aumento de 400 x). 
O método 7 AT obteve resultados favoráveis para ambos parasitos analisados. Com a utilização da suspensão de Giardia spp. a média de porcentagem de organismos não corados (viáveis) foi de $22,4 \%$ e para a suspensão de Cryptosporidium parvum foi de $69 \%$.

Zerbini, Chernicharo e Viana (1999) em estudos preliminares avaliaram o uso do azul de tripano para estimar a viabilidade de ovos de helmintos em amostras de esgoto bruto, com a finalidade de avaliar a fração de ovos que eventualmente completariam seu ciclo biológico, o que representaria a fração potencialmente viável. Os testes de viabilidade realizados indicaram a ocorrência tanto de ovos viáveis quanto de não viáveis, contudo, os resultados são limitados e não permitiram uma análise mais aprofundada sobre o percentual de viabilidade dos ovos.

Bonatti (2007) também avaliou a viabilidade de ovos de helmintos mediante emprego do azul de tripano, e verificou-se a presença de ovos viáveis de Ascaris spp. mesmo após 45 e 90 dias de exposição ao sol.

Ressalta-se que, este método de análise de viabilidade utilizando o azul de tripano ainda não foi testado em (oo) cistos de protozoários, pois artigos associados ao assunto não foram encontrados.

\subsubsection{Avaliação da Estimativa da Viabilidade Utilizando IP em conjunto com DAPI e anticorpos monoclonais FITC}

\subsubsection{Resultado do Método 1 IP - Teste Seguindo a Metodologia de Campbell et al., (1992)}

Neste método não houve nenhum cisto na leitura, visto que sem o uso do kit Merifluor $^{\circledR}$, as membranas dos protozoários não foram coradas, aparecendo somente cristais na lâmina, conforme Figura 32. 


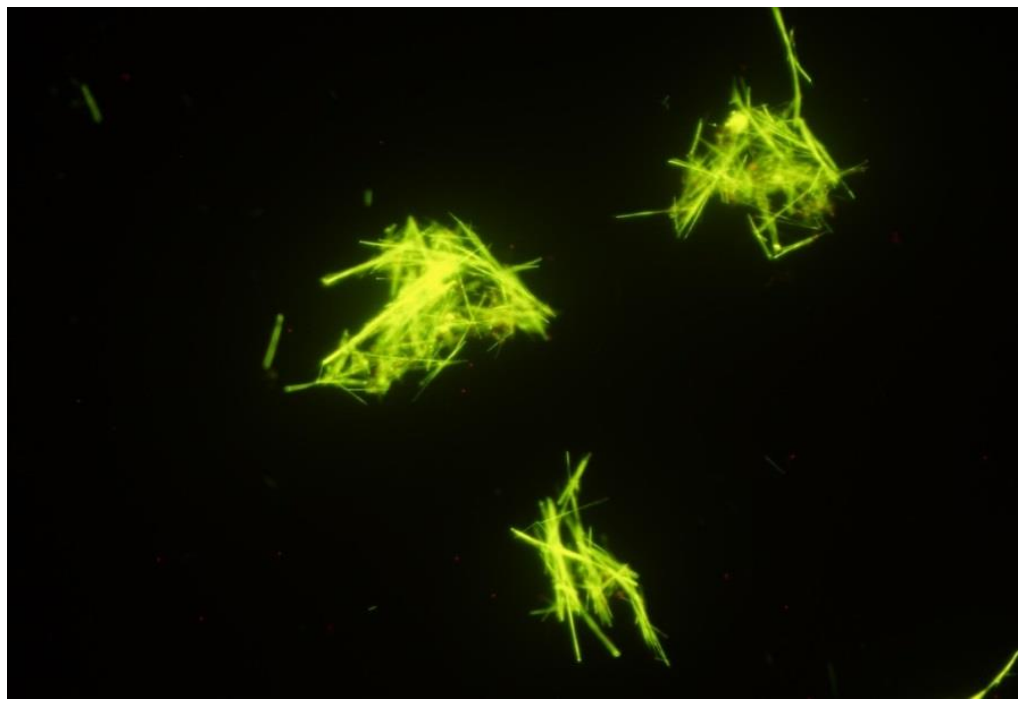

Figura 32: Resultado do Método 1 IP onde houve formação de cristais na lâmina.

Então, como o resultado do primeiro teste foi considerado inviável, o procedimento foi refeito, mas neste caso, utilizando o kit Merifluor ${ }^{\circledR}$.

\subsubsection{Resultado do Método 2 IP - Ensaio Realizado Conforme o Método de Dowd e Pillai (1997)}

O resultado do Método 2 IP está apresentado na Tabela 17. Observa-se que em $50 \mu \mathrm{L}$, foram contabilizados 439 cistos e em $1 \mathrm{~mL}$, o valor seria de 8780 cistos.

Tabela 17: Resultado do Método 2 IP.

\begin{tabular}{lccc}
\hline \multirow{2}{*}{ Giardia lamblia } & Inviável (corado) & Viável (não corado) & \% de inviáveis (corados) \\
\cline { 2 - 4 } & 439 & 0 & 100
\end{tabular}

Alguns problemas foram observados neste ensaio, como, a formação de aglomerados dificultando a contagem (Figura 33) e, também, devido ao longo período de incubação, ao trocar o filtro para a visualização do DAPI, a observação dos núcleos estava comprometida porque a fluorescência era muito intensa e não permitia a visualização dos parasitos. 


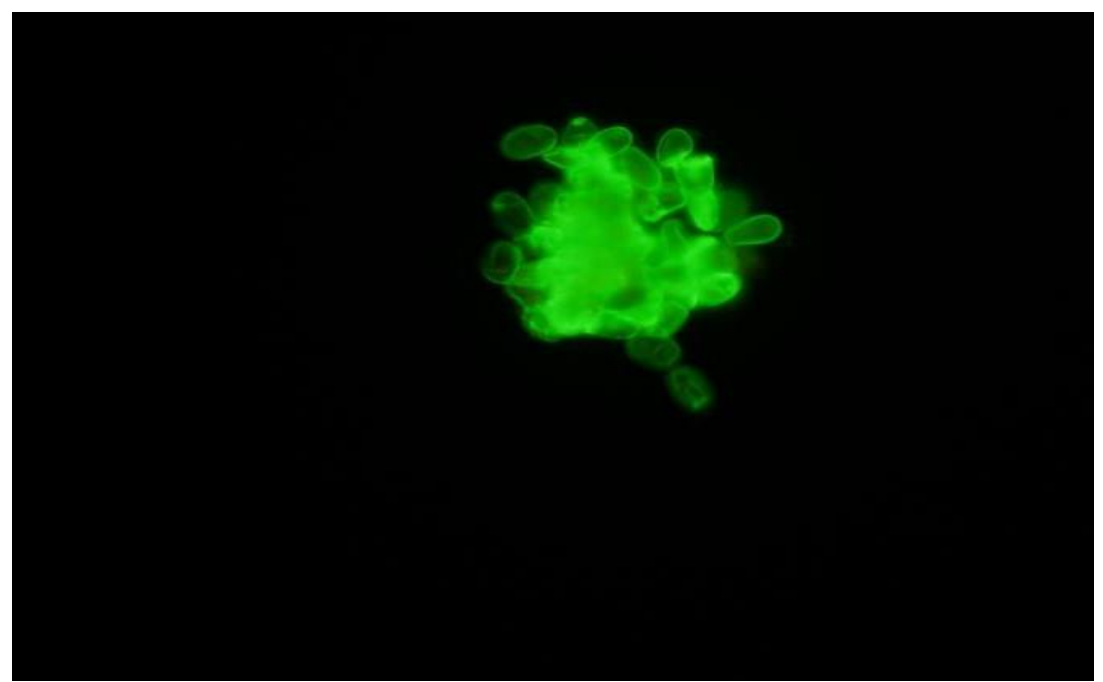

Figura 33: Aglomerado de cistos de Giardia lamblia (Aumento de 400 x).

Dowd e Pillai (1997) em sua pesquisa para determinar a eficácia do método de coloração do IP-IFA para diferenciar oocistos de Cryptosporidium viáveis e inviáveis, empregaram três métodos de inativação diferentes, entre eles, a inativação por aquecimento, inativação pela exposição de micro-ondas, e inativação natural em amostras de água. Alíquotas de $1 \mathrm{~mL}$ das amostras experimentais contendo os oocistos e cistos foram utilizadas e inicialmente incubadas com $100 \mu \mathrm{L}$ da solução de trabalho de IP durante 10 min a $37^{\circ} \mathrm{C}$ em tubos de micro centrífuga.

Os pesquisadores relataram que oocistos viáveis de Cryptosporidium apresentavam paredes celulares verdes fluorescentes sem qualquer fluorescência interna característica, enquanto oocistos não viáveis apresentavam paredes celulares verdes fluorescentes em torno de um centro fluorescente vermelho-alaranjado. No caso dos cistos viáveis de Giardia, a parede do cisto apresentava típica fluorescência verde brilhante em torno de um centro escuro e o cisto inviável, possuía paredes celulares verdes fluorescentes em torno de dois a cinco pontos vermelho-alaranjado fluorescentes, provavelmente representando os núcleos.

\subsubsection{Resultado do Método 3 IP - Substituição do Método de Incubação e Diminuição do Tempo de Contato}

Nos seguintes ensaios, optou-se por fazer algumas alterações na preparação na lâmina, ao invés de incubar os reagentes no microtubo, foram colocados separadamente 
direto na lâmina, isto de acordo com Medeiros (2010), e também incluindo a diminuição do tempo de incubação e os resultados estão apresentados na Tabela 18.

Tabela 18: Resultado do Método 3 IP.

\begin{tabular}{cccc} 
Giardia lamblia & Inviável (corado) & Viável (não corado) & \% de inviável (corados) \\
\cline { 2 - 4 } & 334 & 0 & 100
\end{tabular}

Ao observar os dados da Tabela 18, nota-se que em $50 \mu \mathrm{L}$, foram contabilizados 334 cistos e em $1 \mathrm{~mL}$, o valor seria de 6680 cistos, com $100 \%$ de cistos inviáveis e novamente, houve a formação de aglomerados na lâmina, o que, dificultou a contagem.

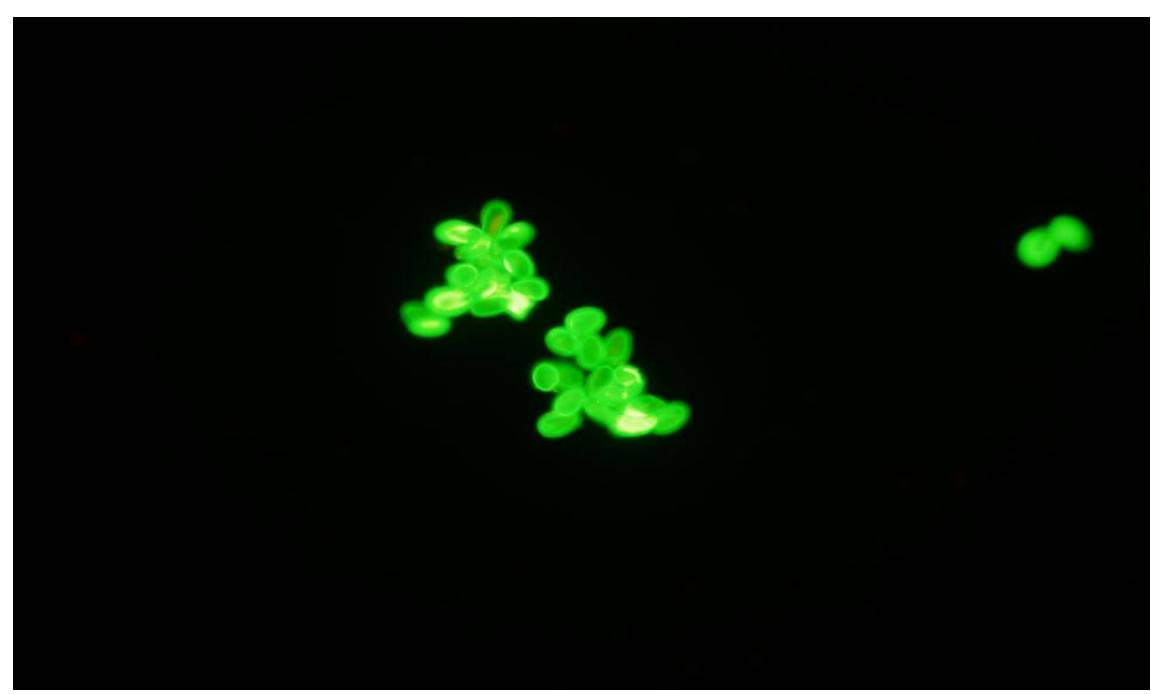

Figura 34: Formação de aglomerados de cistos de Giardia lamblia observados na lente UV (aumento de $400 \mathrm{x}$ ).

Medeiros (2010) utilizou a técnica de Reação de Imunofluorescência Direta (RID) para detecção dos (oo) cistos em amostras de esgoto, a mesma técnica empregada nesta pesquisa e utilizou uma solução DAPI $(50 \mu \mathrm{L})$ por $30 \mathrm{~min}$ à temperatura ambiente. Em seguida, efetuou-se a aplicação do corante IP (30 a $50 \mu \mathrm{L}$ ) deixando em repouso, por no mínimo, $15 \mathrm{~min}$.

5.5.2.4. Resultado do Método 4 IP - Substituição da Solução Preparada de DAPI pela Solução Comercial Fluoroshield ${ }^{\mathrm{MM}}$ with DAPI e Preparação das lâminas com as suspensões de Giardia lamblia e Cryptosporidium parvum da Waterborne 
Os resultados para as suspensões de Giardia lamblia e Cryptosporidium parvum estão apresentados na Tabela 19.

Tabela 19: Resultado da contagem de Giardia lamblia e Cryptosporidium parvum.

\begin{tabular}{ll}
\hline Giardia lamblia & $90+$ aglomerados \\
Cryptosporidium parvum & $84+$ aglomerados
\end{tabular}

No método 4 IP, as mudanças relacionadas ao corante não foram analisadas devido a formação dos aglomerados de (oo) cistos que impossibilitam a contagem e inviabilizaram totalmente o método testado (Figura 35).

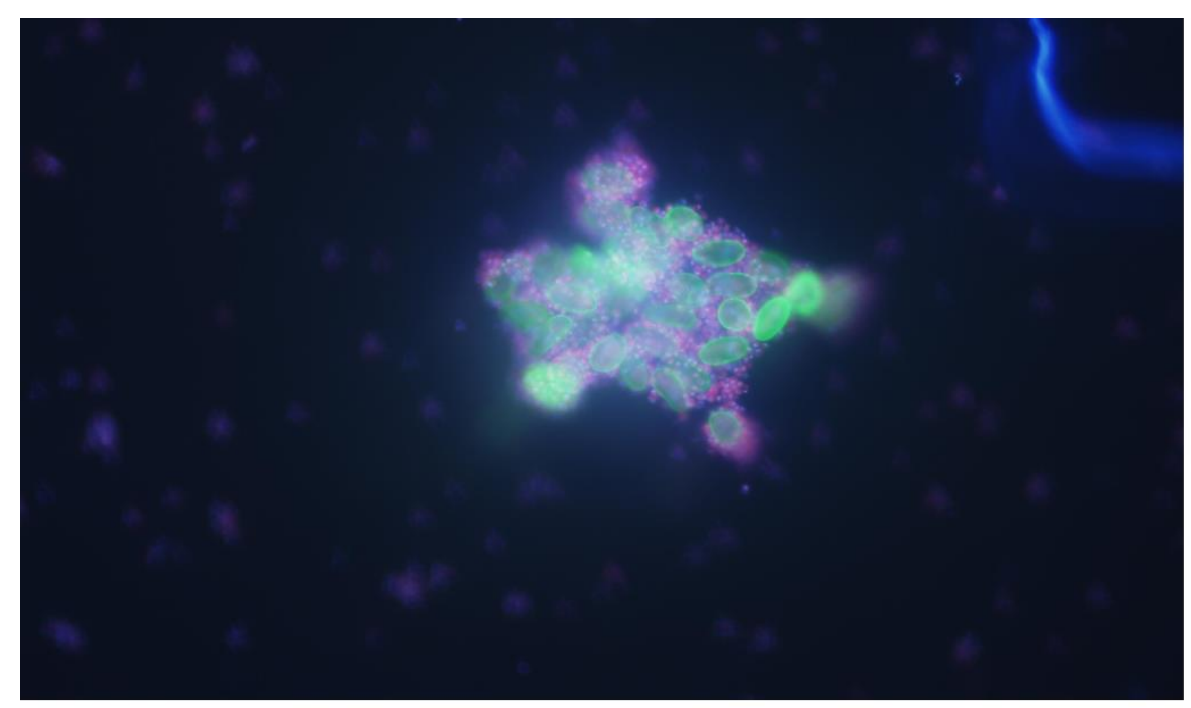

Figura 35: Aglomerado de cistos de Giardia lamblia observados em filtro DAPI com a Solução Comercial Fluoroshield ${ }^{\mathrm{TM}}$ with DAPI (Aumento de $400 \mathrm{x}$ ).

Giglio (2015) teve as mesmas dificuldades em relação à formação de aglomerados com as suspensões de Giardia lamblia e Cryptosporidium parvum, ambas provenientes da Waterborne, mesma empresa utilizada na pesquisa e relata que este fenômeno pode gerar subestimação ou superestimação de inóculo no procedimento de contagem.

Maciel (2014) também reportou a mesma condição de formação de aglomerados de protozoários, fator este que, não possibilitaria a distribuição uniforme destes organismos em meio líquido e para superar este problema, realizou um procedimento que visa romper os agregados, também realizado nesta pesquisa, mas que, entretanto, não foi bem-sucedido. 


\subsubsection{Resultado do Método 5 IP - Alterações do Tempo de Contato do DAPI e IP}

No método 5 IP, uma nova tentativa de desagregação dos agregados foi testada e alterou-se o tempo de contato do DAPI e IP e os resultados estão apresentados na Tabela 20.

Tabela 20: Resultado obtido nas alterações do DAPI, IP e nova contagem da suspensão de Giardia spp.

\begin{tabular}{ccc}
\hline Suspensão & Volume lido $(\mu \mathrm{L})$ & Organismos lidos na lâmina \\
\hline Giardia spp. (UNICAMP) & 10 & 810 cistos \\
Giardia lamblia & 5 & Presença de aglomerados \\
Cryptosporidium parvum & 5 & Ausência de oocistos \\
\hline
\end{tabular}

Novamente foram observados aglomerados na suspensão de Giardia lamblia, que inviabilizou a análise de viabilidade dos cistos (Figura 36) e ausência de oocistos na contagem. A suspensão de Giardia spp. foi avaliada e aglomerados não foram encontrados. Contudo, uma última tentativa foi realizada com as suspensões da Waterborne.

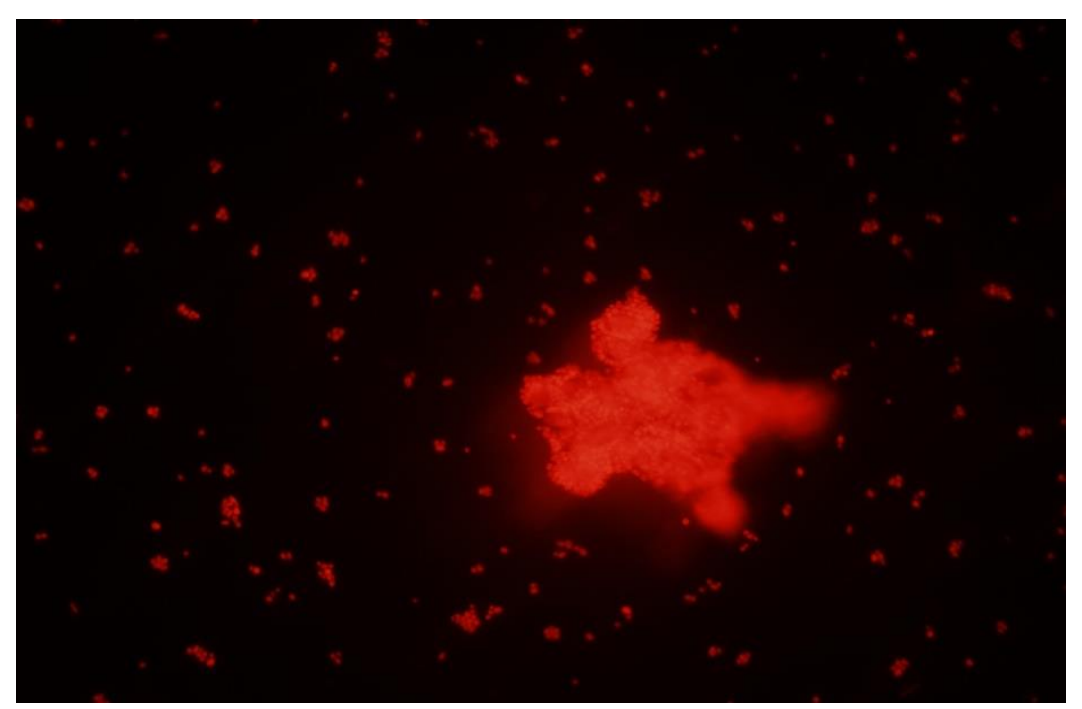

Figura 36: Tentativa de análise de viabilidade observado em filtro WG para visualizar o corante IP utilizando a suspensão de Giardia lamblia com formação de aglomerados (Aumento de $400 \mathrm{x}$ ). 


\subsubsection{Resultado do Método 6 IP - Aumento do Volume do Inóculo das Suspensões de Giardia lamblia e Cryptosporidium parvum}

Uma última tentativa foi efetuada e, assim, optou-se por aumentar o volume do inóculo, visto que no Item 5.5.2.5 a contagem foi realizada com apenas $5 \mu \mathrm{L}$. Os ensaios foram realizados para cada suspensão da Waterborne (em triplicata) e os dados estão apresentados na Tabela 21.

Tabela 21: Resultado do ensaio em triplicata para a suspensão de Giardia lamblia.

\begin{tabular}{cccc}
\hline Suspensões & Poço da lâmina & Alíquota $(\mu \mathrm{L})$ & Contagem de (oo) cistos \\
\hline \multirow{2}{*}{ Giardia lamblia } & 1 & 50 & 38 \\
& 2 & 3 \\
Cryptosporidium parvum & 3 & 50 & $31^{(1)}$ \\
& 1 & & 11 \\
& 2 & & 154 \\
\hline
\end{tabular}

Nota: ${ }^{(1)}=$ formação de aglomerados incontáveis.

Como a aglomeração dos cistos não teve solução, a suspensão da Waterborne foi substituída pela suspensão purificada de Giardia spp. da UNICAMP por não apresentar aglomerados e a suspensão de Cryptosporidium parvum foi mantida, por não apresentar nenhuma dificuldade.

\subsubsection{Resultado do Método 7 IP - Substituição da Suspensão Comercial de Giardia lamblia da Waterborne pela Suspensão Purificada da UNICAMP}

Finalmente, houve a troca da suspensão de Giardia, e para o Método 7 IP, realizou-se nova contagem das suspensões de Giardia spp. e de Cryptosporidium parvum e os resultados estão apresentados na Tabela 22. 
Tabela 22: Resultado do Método 7 IP.

\begin{tabular}{ccccccc}
\hline Suspensões & Poço & $\begin{array}{c}\text { Alíquota } \\
(\mu \mathrm{L})\end{array}$ & $\begin{array}{c}\text { Inviáveis } \\
(\text { corados })\end{array}$ & $\begin{array}{c}\text { Viáveis (não } \\
\text { corados) }\end{array}$ & $\begin{array}{c}\% \\
\text { Inviável }\end{array}$ & $\begin{array}{c}\% \\
\text { Viável }\end{array}$ \\
\hline Giardia spp. & 1 & 10 & 187 & 66 & 73,9 & 26,1 \\
\hline $\begin{array}{c}\text { Cryptosporidium } \\
\text { parvum }\end{array}$ & 1 & 50 & 41 & 48 & 46,1 & 53,9 \\
\hline
\end{tabular}

Com todas as modificações realizadas, a porcentagem de cistos de Giardia spp. viáveis era de $26,1 \%$ e de oocistos de Cryptosporidium parvum era de aproximadamente $53,9 \%$.

Na Figura 37 estão as imagens de cistos de Giardia, um corado e outro não. A Figura 38 indica oocistos de Cryptosporidium, sem e com a inclusão do corante. As Figuras 39 e 40 representam as imagens dos (oo) cistos visualizados em DAPI.

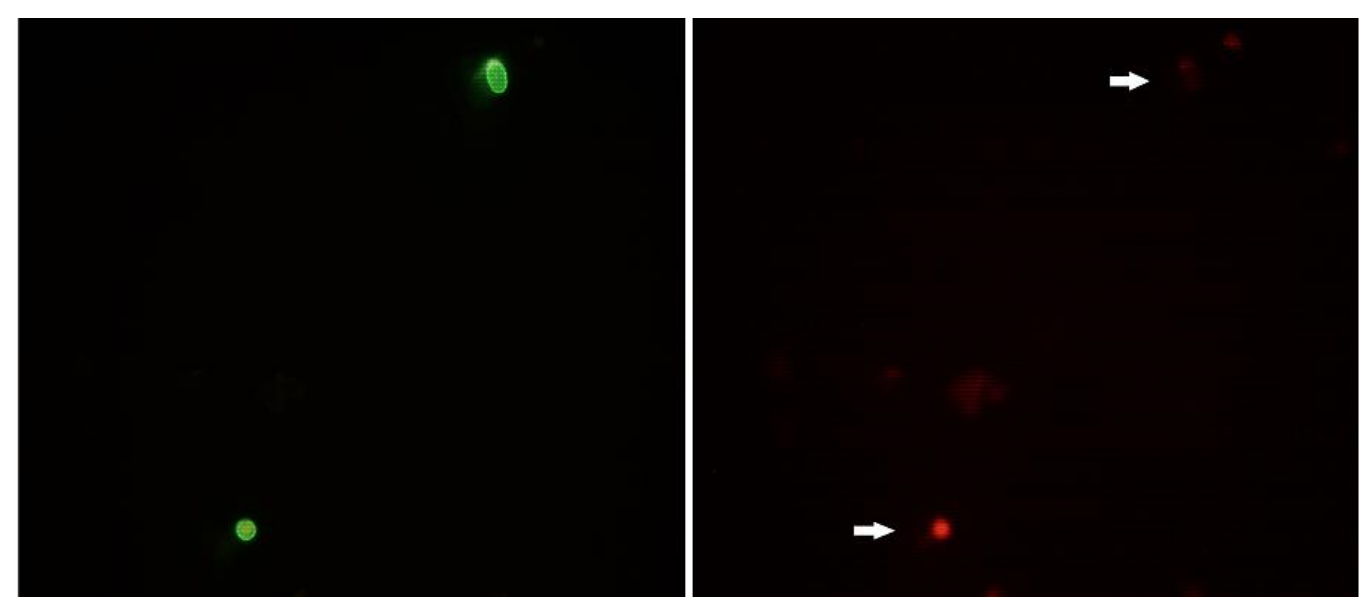

Figura 37: Do lado esquerdo são visualizados 2 cistos de Giardia spp. na lente UV. Do lado direito, os cistos foram observados em lente WG para visualizar o IP, a flecha de cima aponta o cisto não corado e a de baixo, o corado (aumento de $400 \mathrm{x}$ ). 


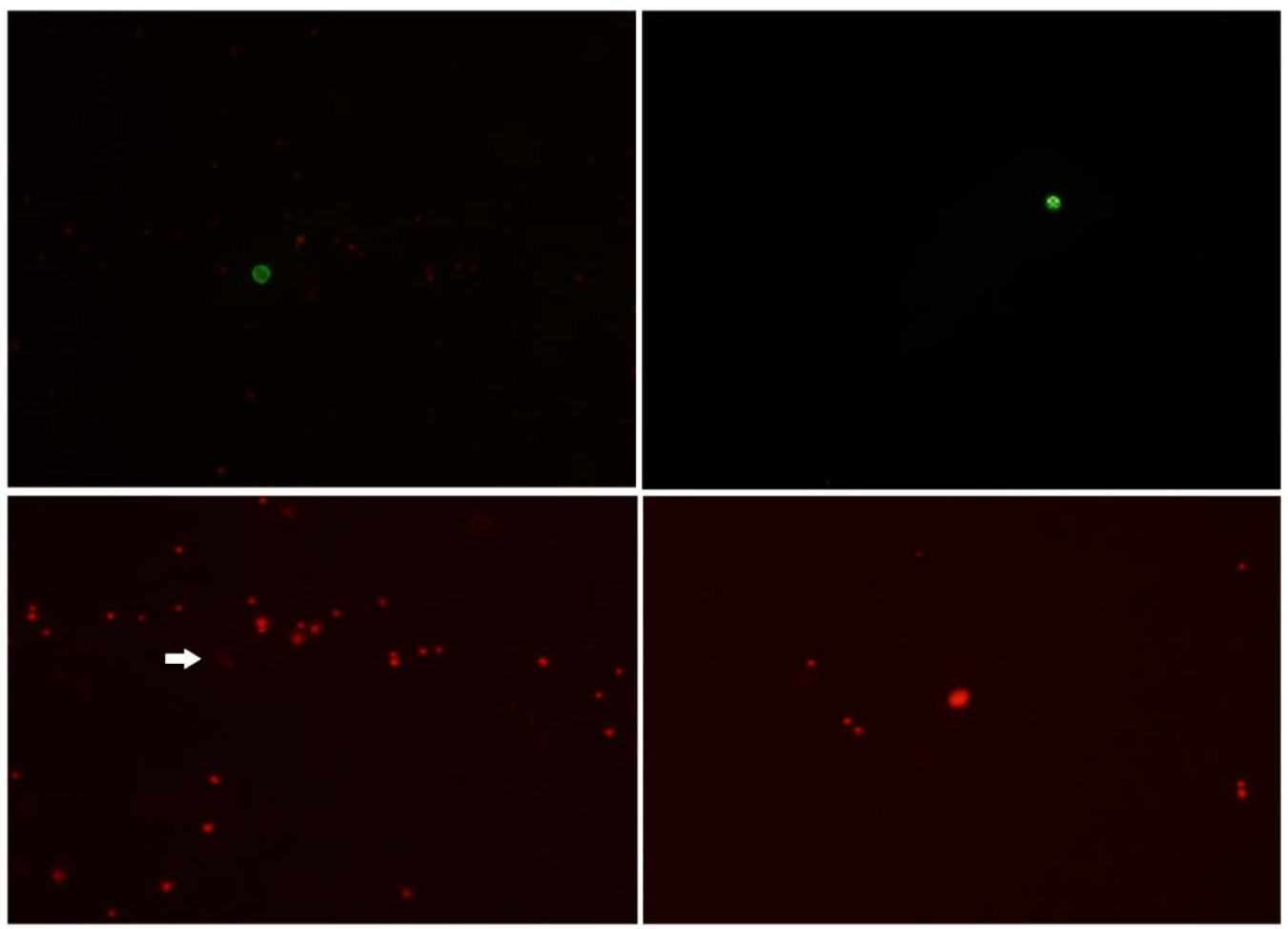

Figura 38: Na parte superior, visualizaram-se oocisto na lente UV. Na parte inferior, do lado esquerdo, observa-se o oocisto sem a penetração do corante e do lado direito, com a inclusão do corante (aumento de 400 x).
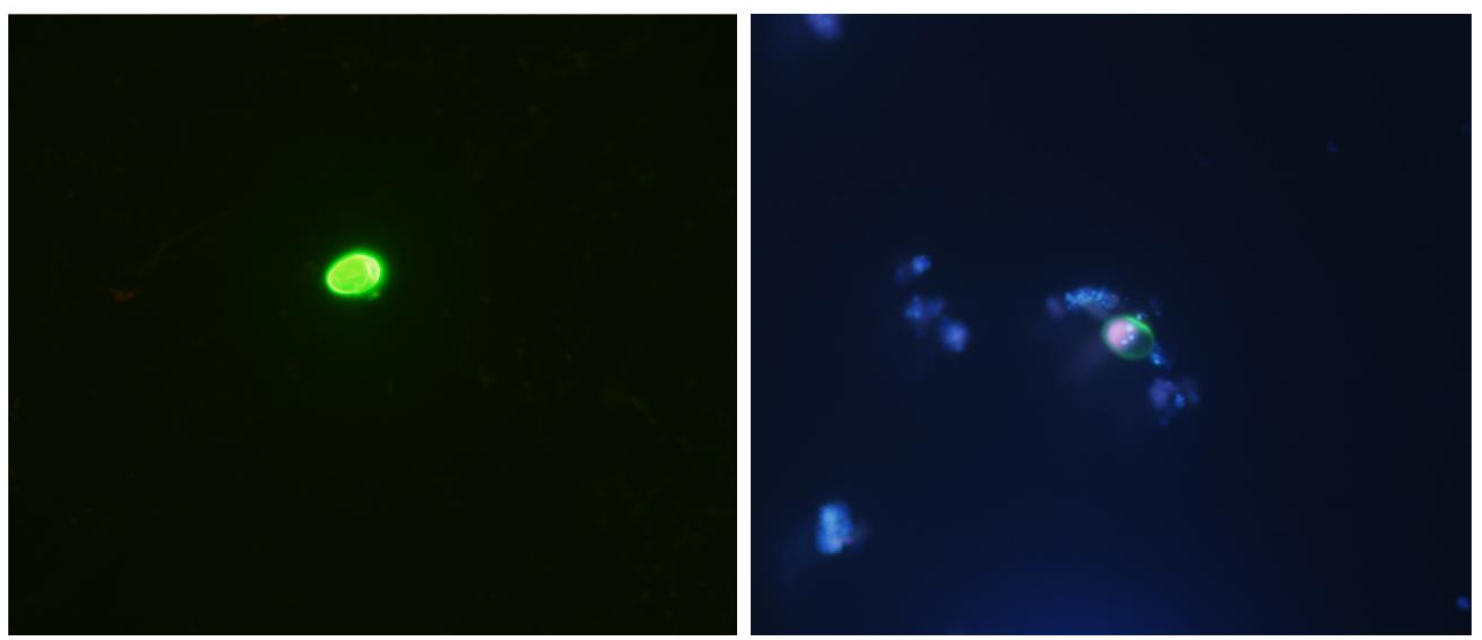

Figura 39: Visualização de um cisto de Giardia spp., à esquerda em lente UV e a direita em DAPI com 3 núcleos (Aumento de 400 x). 

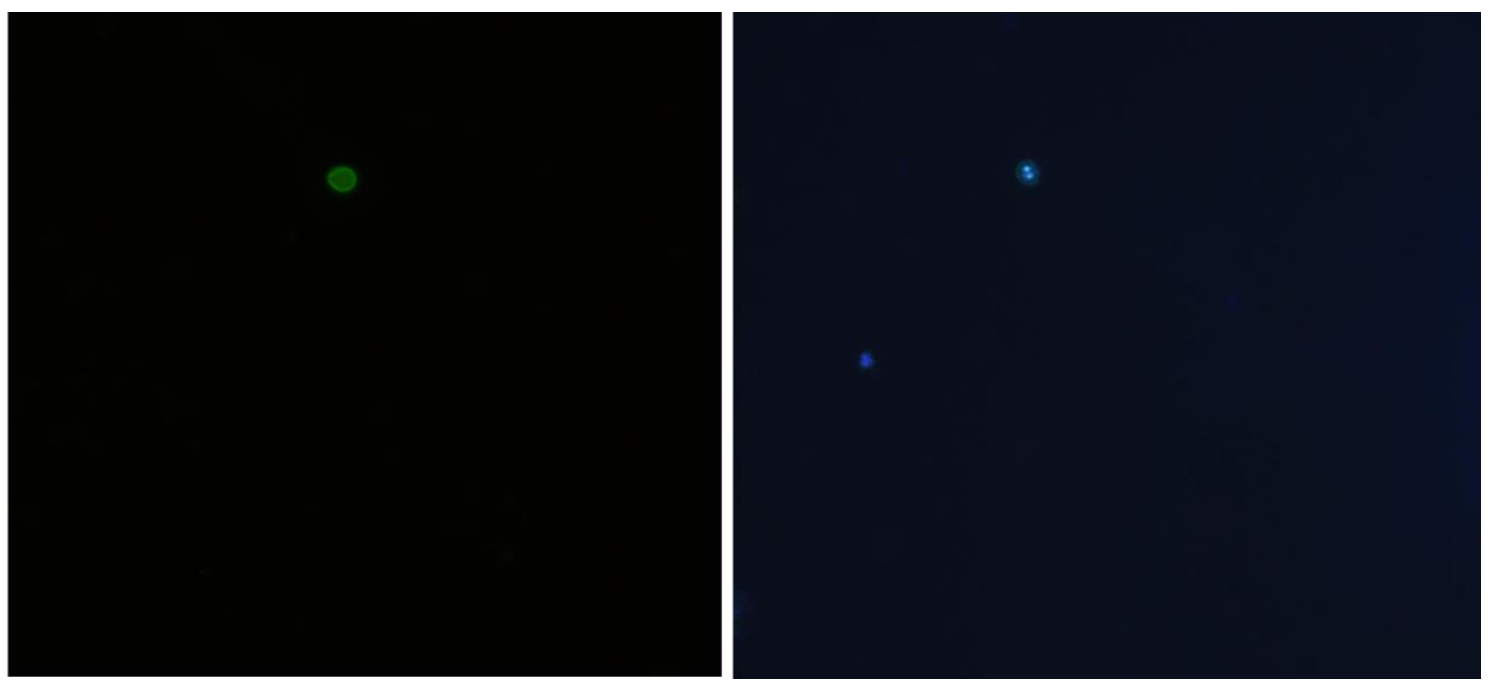

Figura 40: Visualização de um oocisto de Cryptosporidium parvum, à esquerda em lente UV e a direita em DAPI com 2 núcleos (Aumento de 400 x).

\subsubsection{Resultado do Método 8 IP - Otimização do Tempo de Incubação do IP}

Um último ensaio visando otimizar o tempo de contato do IP foi realizado, para ambos parasitos, analisando tempo de 5, 10 e $15 \mathrm{~min}$ em ensaios realizados em triplicata, e os dados obtidos estão demonstrados nas Tabelas 23 a 25.

Tabela 23: Resultados da leitura da suspensão de Giardia spp. e Cryptosporidium parvum com tempo de 5 min para o IP.

\begin{tabular}{ccccccc}
\hline Suspensões & Poço & $\begin{array}{c}\text { Alíquota } \\
(\mu \mathrm{L})\end{array}$ & $\begin{array}{c}\text { Inviáveis } \\
(\text { corados })\end{array}$ & $\begin{array}{c}\text { Viáveis } \\
(\text { não corados })\end{array}$ & $\begin{array}{c}\% \\
\text { Inviável }\end{array}$ & $\begin{array}{c}\% \\
\text { Viável }\end{array}$ \\
\hline \multirow{2}{*}{ Giardia spp. } & 1 & & 405 & 70 & 85,3 & 14,7 \\
& 2 & 50 & 564 & 112 & 83,4 & 16,6 \\
\hline \multirow{2}{*}{ Cryptosporidium } & 1 & & 354 & 76 & 82,3 & 17,7 \\
\hline parvum & 2 & 50 & 9 & 31 & 35,4 & 64,6 \\
& 3 & & 9 & 14 & 39,1 & 60,9 \\
& & & & & 45,0 & 55,0 \\
\hline
\end{tabular}


Tabela 24: Resultados da leitura da suspensão de Giardia spp. e Cryptosporidium parvum com tempo de 10 min para o IP.

\begin{tabular}{ccccccc}
\hline Suspensões & Poço & $\begin{array}{c}\text { Alíquota } \\
(\mu \mathrm{L})\end{array}$ & $\begin{array}{c}\text { Inviáveis } \\
(\text { corados })\end{array}$ & $\begin{array}{c}\text { Viáveis (não } \\
\text { corados) }\end{array}$ & $\begin{array}{c}\% \\
\text { Inviável }\end{array}$ & $\begin{array}{c}\% \\
\text { Viável }\end{array}$ \\
\hline \multirow{2}{*}{ Giardia spp. } & 1 & & 564 & 70 & 88,9 & 11,1 \\
& 2 & 50 & 476 & 113 & 80,8 & 19,2 \\
& 3 & & 986 & 102 & 90,6 & 9,4 \\
\hline \multirow{2}{*}{ Cryptosporidium } & 1 & & 6 & 7 & 46,1 & 53,9 \\
parvum & 2 & 50 & 12 & 10 & 54,5 & 45,5 \\
& 3 & & 12 & 16 & 42,9 & 57,1 \\
\hline
\end{tabular}

Tabela 25: Resultados da leitura da suspensão de Giardia spp. e Cryptosporidium parvum com tempo de 15 min para o IP.

\begin{tabular}{ccccccc}
\hline Suspensões & Poço & $\begin{array}{c}\text { Alíquota } \\
(\mu \mathrm{L})\end{array}$ & $\begin{array}{c}\text { Inviáveis } \\
(\text { corados })\end{array}$ & $\begin{array}{c}\text { Viáveis (não } \\
\text { corados) }\end{array}$ & $\begin{array}{c}\% \\
\text { Inviável }\end{array}$ & $\begin{array}{c}\% \\
\text { Viável }\end{array}$ \\
\hline \multirow{2}{*}{ Giardia spp. } & 2 & 50 & 645 & 57 & 91,9 & 8,1 \\
& 3 & & 740 & 60 & 92,5 & 7,5 \\
\hline \multirow{2}{*}{ Cryptosporidium } & 1 & & 18 & 2 & 90,0 & 10,0 \\
parvum & 2 & 50 & 14 & 6 & 70,0 & 30,0 \\
& 3 & & 23 & 4 & 85,2 & 14,8 \\
\hline
\end{tabular}

Diante dos resultados obtidos e observando a porcentagem de cistos de Giardia spp. não corados de $16,3 \% \pm 1,2$ e de oocistos de Cryptosporidium parvum de 60,2\% \pm 4 (para o tempo de $5 \mathrm{~min}$ ) (Figura 41 e 42), escolheu-se o tempo de contato de $5 \mathrm{~min}$ para a realização dos ensaios posteriores. 


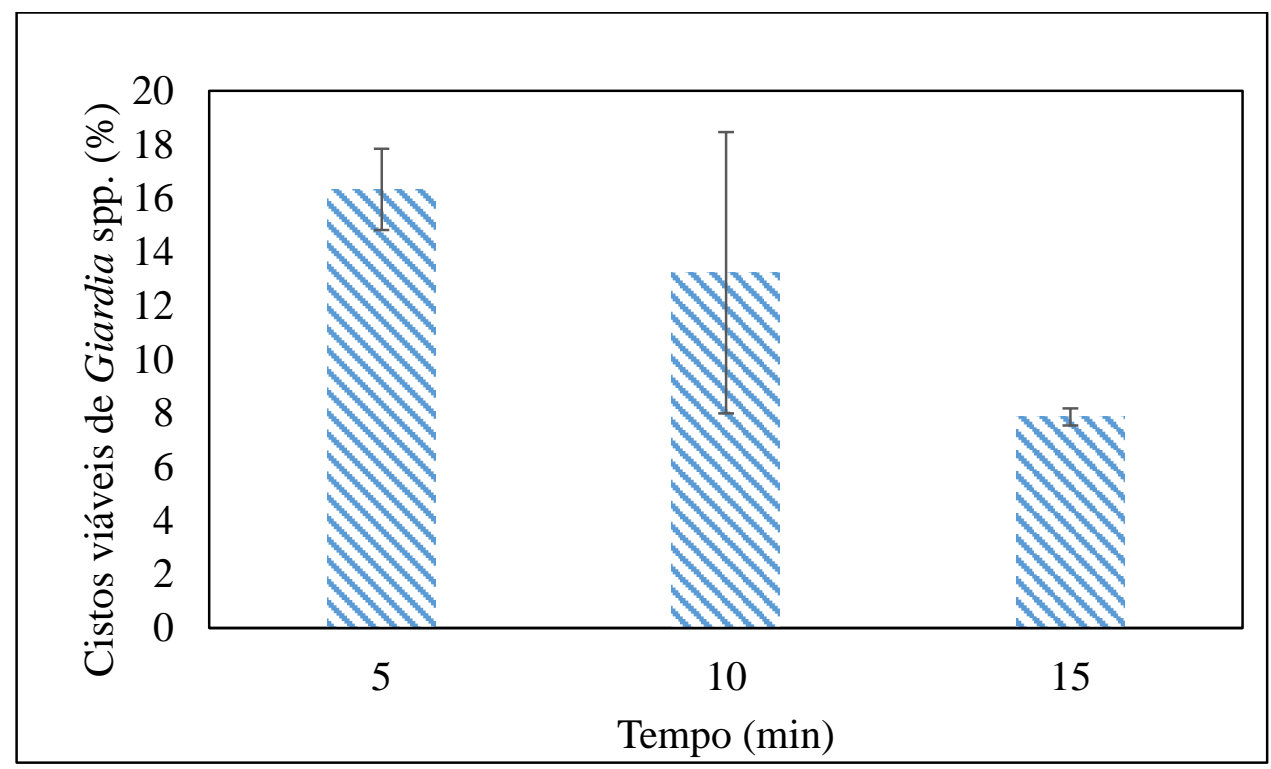

Figura 41: Porcentagem de cistos de Giardia spp. não corados (viáveis) para os tempos de exposição de 5, 10 e 15 min, calculados a partir da média e desvio padrão.

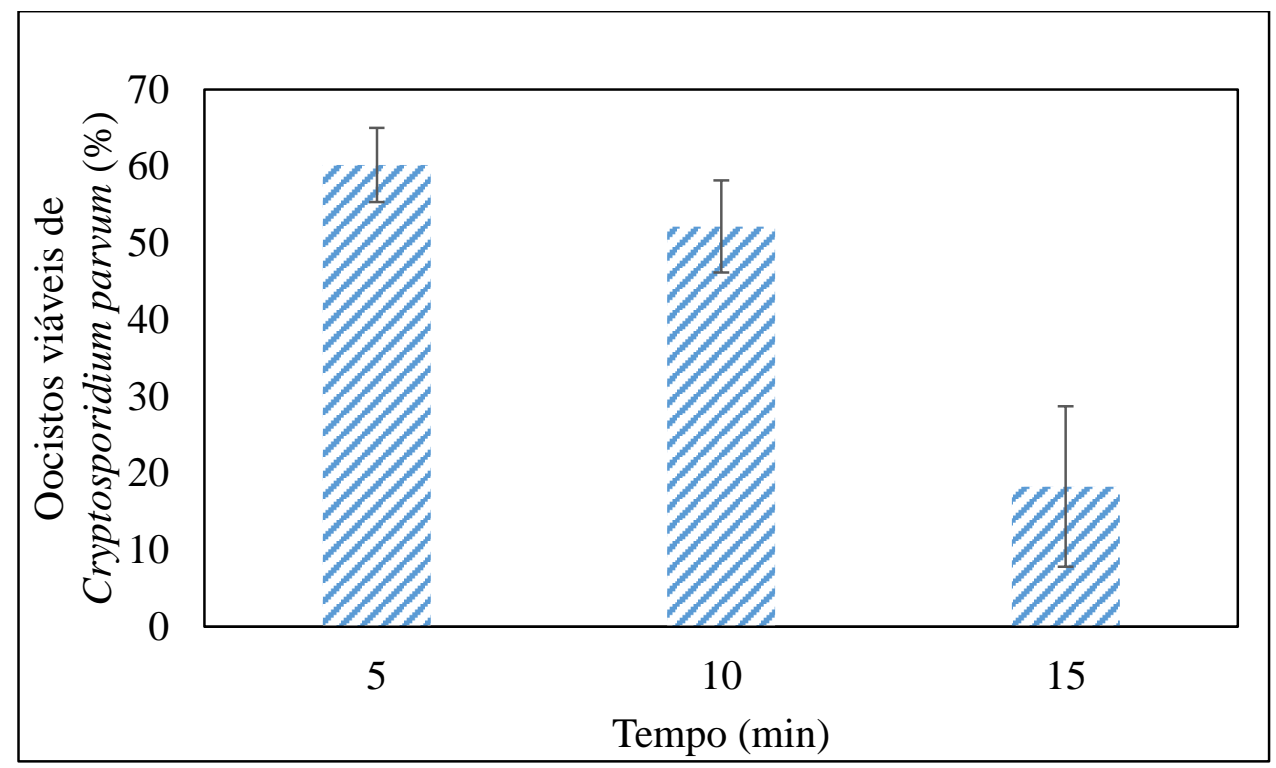

Figura 42: Porcentagem de oocistos de Cryptosporidium parvum não corados (viáveis) para os tempos de exposição de 5, 10 e 15 min, calculados a partir da média e desvio padrão.

De acordo com os dados apresentados nas Figuras 41 e 42, quanto maior o tempo de contato com o IP, menor é a porcentagem de (oo) cistos não corados (viáveis), o que pode indicar resultados falso-positivos, provocados pela longa exposição ao corante, e com isso, inferir na viabilidade dos parasitos. Portanto, o tempo de contato de 5 min foi o selecionado. 
O estudo de Schupp e Erlandsen (1987) foi realizado para determinar a eficácia do método de diacetato de fluoresceína (FDA) e IP para avaliar viabilidade de cistos de Giardia muris. Pellets dos cistos foram corados com estes corantes em concentrações de ambos $4 \mu \mathrm{g}$ de FDA por $10^{6}$ cistos ou $3 \mu \mathrm{g}$ de IP por $10^{6}$ cistos e os cistos foram corados durante 5 min antes da análise microscópica, mesmo valor utilizado nesta pesquisa.

Campbell et al., (1992) pesquisaram sobre a viabilidade de oocistos de Cryptosporidium parvum baseado na inclusão/exclusão dos corantes vitais DAPI e IP e incubaram $100 \mu \mathrm{L}$ da suspensão ( 2 x $10^{4}$ oocistos por $\mu \mathrm{L}$ de HBSS) simultaneamente com $10 \mu \mathrm{L}$ de DAPI e $10 \mu \mathrm{L}$ de IP a $37^{\circ} \mathrm{C}$. A inclusão do IP pelos oocistos foi máxima após 5 min de incubação.

Vergara-Castiblanco et al., (2000) e Freire-Santos et al., (2000) analisaram a viabilidade de oocistos com uso dos corantes vitais DAPI e IP, e utilizaram alíquotas de $10 \mu \mathrm{L}$ contendo aproximadamente $2 \times 10^{6}$ oocistos, que foram adicionados a $100 \mu \mathrm{L}$ de HBSS e incubadas simultaneamente com $10 \mu \mathrm{L}$ de DAPI e $10 \mu \mathrm{L}$ de IP adotando o mesmo método utilizado por Campbell et al., (1992), adotando assim, o mesmo tempo de 5 min de incubação para o IP.

Dowd e Pillai (1997) utilizaram o IP para determinação de viabilidade rápida que pode ser utilizado em conjunto com o método atual de anticorpos fluorescente indireto (AFI) para a detecção de (oo) cistos. Os cistos e oocistos $\left(10^{4}-10^{5}\right)$ foram inoculados em alíquotas de $1 \mathrm{~mL}$ da amostra (utilizaram água com alta turbidez seguida de concentração) e incubadas com $100 \mu \mathrm{L}$ de IP durante 10 min a $37^{\circ} \mathrm{C}$. Este tempo de 10 min, quando comparado a presente pesquisa, pode superestimar os resultados, pois apresentou uma porcentagem maior de (oo) cistos corados, além de que, observando as Figuras 41 e 42, o tempo de $10 \mathrm{~min}$, apresenta um desvio padrão maior em relação ao tempo de $5 \mathrm{~min}$.

A Figura 43, representa uma imagem da otimização do tempo de contato de 15 min, em que sem trocar de filtro, os (oo) cistos já estavam corados, indicando a intensidade deste valor de tempo analisado, que foi descartado. 

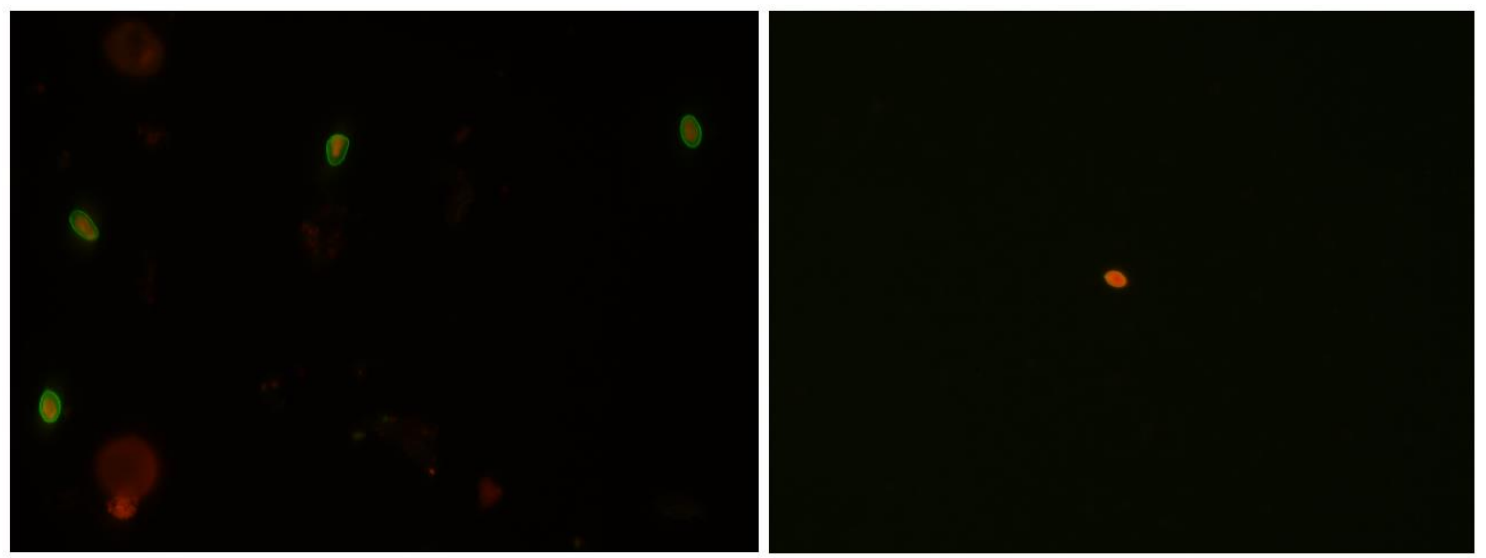

Figura 43: Imagem dos (oo) cistos durante ensaio do tempo de contato de 15 min de IP. À esquerda: 4 cistos de Giardia coradas e à direita, 1 oocisto de Cryptosporidium corado.

5.5.3. Avaliação comparativa entre os métodos de estimativa da viabilidade utilizando o Azul de Tripano e o IP em conjunto com DAPI e anticorpos monoclonais FITC

O resumo dos resultados obtidos nos dois métodos estão apresentados na Tabela 26.

Tabela 26: Resultado da comparação dos resultados obtidos a partir do uso do azul de tripano e do iodeto de propídio.

\begin{tabular}{c|c|c}
\hline & \multicolumn{2}{|c}{$\begin{array}{c}\text { Corantes (média da porcentagem de (oo) cistos não corados (viáveis) } \\
\pm \text { Desvio Padrão) }\end{array}$} \\
\hline Suspensões & Azul de tripano & Iodeto de propídio \\
\hline Giardia spp. & $22,4 \pm 10,3$ & $16,3 \pm 1,2$ \\
\hline $\begin{array}{c}\text { Cryptosporidium } \\
\text { parvum }\end{array}$ & $69 \pm 2,2$ & $60,2 \pm 4$ \\
\hline
\end{tabular}

Para justificar o uso dos corantes, uma estimativa foi feita, e pode ser observada pelos dados demonstrados na Tabela 26, em que as porcentagens de organismos viáveis utilizando o corante azul de tripano estão apresentadas. Neste método a utilização da suspensão de Giardia spp. apresentou um valor médio de organismos viáveis de $22,4 \%$ $\pm 10,3$, e para a suspensão de Cryptosporidium parvum de $69 \% \pm 2,2$. E observando os dados da mesma Tabela 26, utilizando as mesmas suspensões para o corante IP, nota-se 
que foram estimados 16,3\% $\pm 1,2$ de organismos viáveis para a suspensão de Giardia spp. e 60,2\% \pm 4 para a suspensão de Cryptosporidium parvum.

Para saber se as diferenças entre os corantes testados são estatisticamente significativas, um teste de hipótese foi aplicado (Teste - t: duas amostras em par para médias, utilizando o Microsoft Excel 2013), considerando 95\% de nível de confiança dos testes, ou seja, valor-p < 0,05, e assim foi possível verificar que, comparando os valores de Giardia spp. para o azul de tripano e para o IP, obteve-se valor- $p=0,08$ e para Cryptosporidium parvum o valor-p foi de 0,83 , que indica que a diferença estatística não foi significativa ( $\mathrm{p}>0,05)$, não houve variabilidade entre os métodos testados e os valores obtidos são similares, apresentando pouca variabilidade quando comparados um ao outro.

Portanto, o método do corante do IP foi o escolhido para a continuação da pesquisa. Este fato ocorreu aliado ao fato de que, apresenta maior facilidade deste corante em relação ao azul de tripano. Este último possui procedimento simples de preparação das lâminas, contudo, apresenta maiores dificuldades na etapa de leitura no campo claro. Outro problema recorrente é a formação de bolhas, mesmo com todo o cuidado laboratorial, isto no momento de preparação da lâmina, que durante a leitura podem ser confundidas com os organismos-alvo, além de ter que se preparar uma lâmina por vez, ou seja, uma no começo e outra no final do ensaio, além da preparação das lâminas de contagem dos parasitos. Neste método, o tempo de leitura da lâmina recomendando na bula é de $5 \mathrm{~min}$, que é muito curto, e durante os ensaios este período foi ultrapassado, fator este que, pode influenciar na estimativa de viabilidade, devido à longa exposição.

Em contrapartida, o IP apresenta menor complexidade, pois o corante é colocado durante o procedimento de preparação da lâmina, e em somente um ensaio a contagem e a avaliação da viabilidade podem ser realizadas, economizando tempo. Dowd e Pillai (1997) também citam que, o IP proporciona essa vantagem, de tanto a detecção e a determinação da viabilidade podem ser realizadas ao mesmo tempo, usando a mesma amostra. Isto, aliado ao fato de que, pela leitura ser em FITC, os organismos estão fluorescentes e existe apenas a troca de filtro no microscópio para verificar se os parasitos penetraram ou expulsaram o corante, assim, o ensaio fica mais simples. 


\subsection{Controle da Qualidade Analítica do Método de Concentração (FCCa) em Amostras de Água}

\subsubsection{Controle da Qualidade Analítica do Método de FCCa sem IMS Utilizando Suspensões de (oo) cistos}

Para iniciar o ensaio de controle da qualidade analítica do método de FCCa sem IMS com as suspensões de protozoários, foi necessário realizar a determinação da concentração de protozoários nas suspensões para posterior inóculo, atividade que foi realizada com $5 \mu \mathrm{L}$ da suspensão de Giardia spp. e $50 \mu \mathrm{L}$ de Cryptosporidium parvum, em triplicata (Tabela 27).

Tabela 27: Resultado da contagem em triplicata das suspensões de Giardia spp. (5 $\mu \mathrm{L})$ e Cryptosporidium parvum $(50 \mu \mathrm{L})$ para posterior inóculo.

\begin{tabular}{ccccc}
\hline Suspensões & $\begin{array}{c}\text { Poço da } \\
\text { lâmina }\end{array}$ & $\begin{array}{c}\text { Alíquota } \\
(\mu \mathrm{L})\end{array}$ & $\begin{array}{c}\text { Contagem } \\
\text { de (oo) } \\
\text { cistos }\end{array}$ & $\begin{array}{c}\text { Média de (oo) cistos } \\
\pm \text { DP ou } \pm \text { CV }(\%)\end{array}$ \\
\hline Giardia spp. & 1 & & 464 & \\
& 2 & 5 & 370 & $454 \pm 65 \pm 14$ \\
Cryptosporidium & 3 & & 528 & \\
parvum & 1 & & 843 & \\
\hline
\end{tabular}

O ensaio de controle de qualidade foi realizado 4 vezes e o teste branco, seguindo o protocolo do Método 1623.1 (Tabela 28), isto inoculando $5 \mu \mathrm{L}$ da suspensão de Giardia spp. e $50 \mu \mathrm{L}$ da suspensão de Cryptosporidium parvum, na água filtrada, utilizando o procedimento de FCCa, neste caso avaliado somente sem o IMS.

Para os cálculos da recuperação foram utilizados os seguintes dados: volume final de cada amostra: $1 \mathrm{~mL}(1000 \mu \mathrm{L})$; volume total de alíquotas dos poços: $150 \mu \mathrm{L}$; e $\mathrm{FM}=6,7$. 
Tabela 28: Resultado do método de concentração de FCCa sem IMS utilizando as suspensões de Giardia spp. e Cryptosporidium parvum.

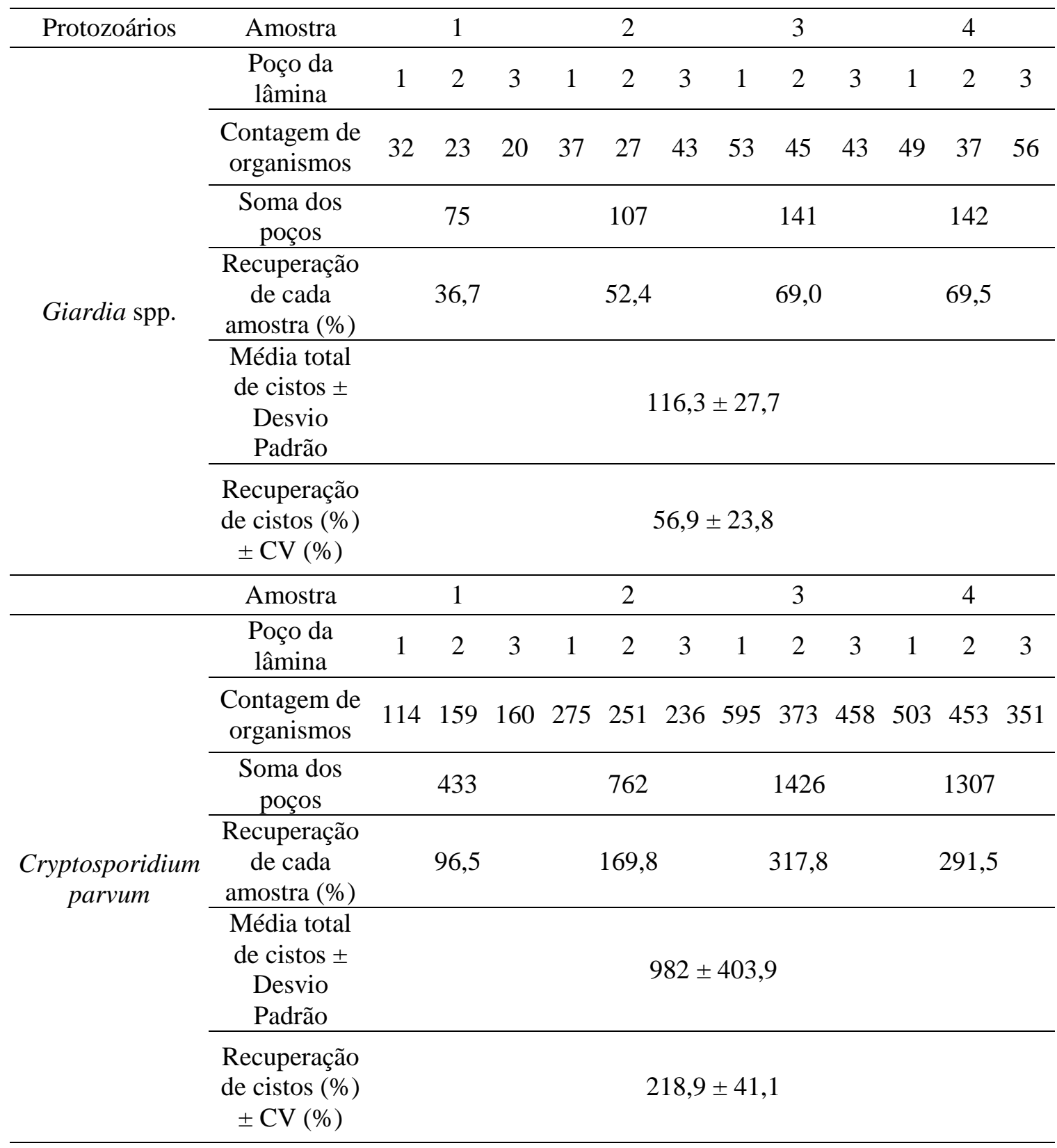

No ensaio não foram encontrados (oo) cistos na lâmina da amostra do branco, o que indica a inexistência de contaminação no teste.

A partir dos dados demonstrados na Tabela 28, pode-se observar que o ensaio obteve recuperações altas. A recuperação de Giardia spp. foi de 56,9\% $\pm 23,8 \%$, o que indica que está dentro do padrão estabelecido, que é de $8 \%$ para cistos de Giardia. Em contrapartida, para oocistos de Cryptosporidium parvum, o valor de recuperação de acordo com o Método é de $32 \%$, e a recuperação neste ensaio, foi de $218,9 \% \pm 41,1 \%$, 
valor impraticável. Este resultado mostra que a quantidade de protozoários inoculada poderia ser maior que o valor estimado na etapa de contagem.

Giglio (2015) também obteve recuperação de Cryptosporidium parvum superior a $100 \%$, e aponta que este fato pode ser explicado pela variação da contagem, que indica que apesar da rigorosa homogeneização das suspensões, não seria possível coletar alíquotas com concentrações ou quantidades iguais de (oo) cistos. Portanto, sempre haverá um erro na determinação da quantidade exata de (oo) cistos inoculados.

Santos et al., (2011) também encontraram recuperações acima de 100\% e afirmam que níveis de recuperação superiores a $100 \%$ podem ocorrer e este fato está relacionado à padronização do inóculo utilizado na avaliação. A enumeração das formas previamente à diluição e inoculação não são passos fáceis, devido os aspectos biológicos como idade e origem dos organismos, procedimentos prévios de limpeza, o meio e o tempo de armazenamento da suspensão podem influenciar na agregação das formas e, com isso, nos valores de recuperação.

\subsubsection{Controle da Qualidade Analítica do Método de FCCa sem e com IMS utilizando o EasySeed ${ }^{\circledR}$}

O ensaio de controle de qualidade foi realizado utilizando as suspensões do kit Easyseed $^{\circledR}$, que possui um número de protozoários conhecidos, sendo inoculados em 1 L da água de estudo para atestar o método de FCCa em IMS. De acordo com as informações do kit (Anexo D), cada frasco, possui uma média de 99 cistos de Giardia lamblia com desvio padrão de 1,5 e média de 99 oocistos de Cryptosporidium parvum com desvio padrão de 1,4 .

Quatro testes para o método de concentração FCCa foram realizados e mais quatro testes para verificar a recuperação do método de concentração seguido da etapa de separação imunomagnética (IMS). As primeiras 4 amostras são para o teste sem IMS (Tabela 29). Foram inoculados $50 \mu \mathrm{L}$ em cada poço e o ensaio foi realizado em triplicata. Para os cálculos de recuperação foram utilizados os seguintes dados: volume final de cada amostra: 1,0 mL; volume total de alíquotas dos poços: $150 \mu \mathrm{L}$; e FM = 6,7 .

Os resultados do ensaio de FCCa sem IMS estão apresentados na Tabela 29 e a os resultados do teste de FCCa com IMS estão indicados na Tabela 30. 
Tabela 29: Resultado do ensaio de qualidade analítica do protocolo de FCCa sem IMS com o kit Easyseed ${ }^{\circledR}$.

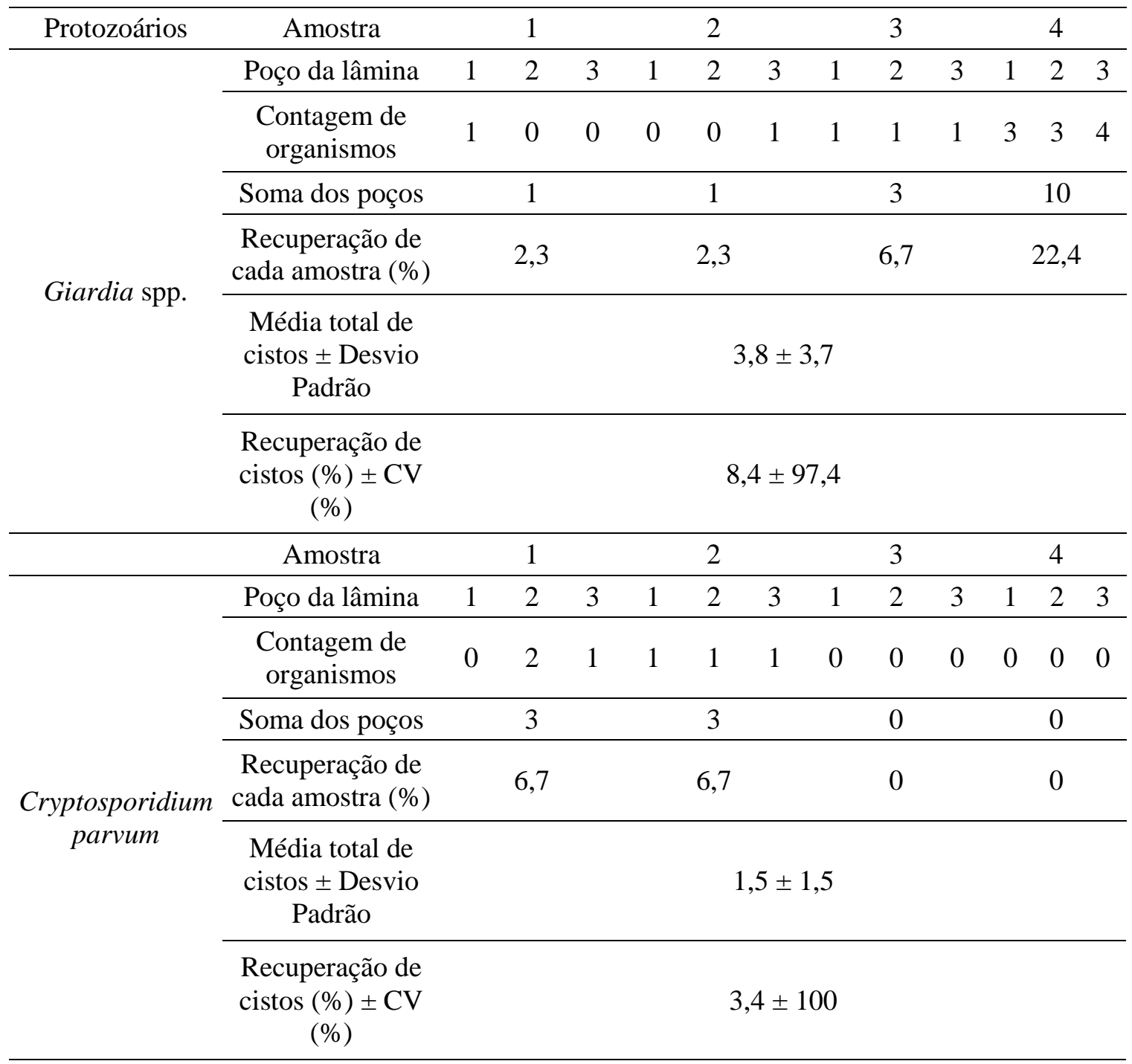

No ensaio não foram encontrados (oo) cistos na lâmina da amostra do branco, o que indica a inexistência de contaminação no teste.

Na Tabela 29, no ensaio de FCCa sem IMS pode-se observar que a recuperação de cistos de Giardia foi de $8,4 \% \pm 97,4 \%$ e atendeu ao padrão estabelecido pelo Método 1623.1. Já a recuperação de oocistos de Crypstosporidium foi de $3,4 \% \pm 100 \%$, não atendendo as normas.

Maciel (2014) utilizou água com turbidez elevada, concentrou as amostras por filtração em membranas, e realizou testes de controle de qualidade sem IMS com o kit Easyseed $^{\circledR}$. Para cistos de Giardia spp., a taxa média de recuperação foi de $80 \%$ (CV = 20,4\%) e para oocistos de Cryptosporidium spp., foi de 5\% $(\mathrm{CV}=200 \%)$. O método utilizado foi aceitável em relação à recuperação de cistos de Giardia spp., porém não foi 
satisfatório para oocistos de Cryptosporidium spp., mesma condição obtida nesta pesquisa. Este fato se deve principalmente ao padrão de coloração mais fraco e tamanho inferior dos oocistos comparado aos cistos.

Cantusio Neto (2008) avaliou ensaios realizados com água reagente utilizando o

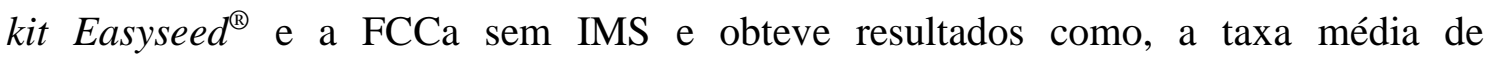
recuperação foi de 5,8\% $\pm 3,8(\mathrm{CV}=65,5 \%)$ para cistos de Giardia spp. e 5,3\% $\pm 2,8$ para oocistos de Cryptosporidium spp. $(\mathrm{CV}=52,8 \%)$, ou seja, as recuperações não atingiram os valores estabelecidos no Método 1623.1 para nenhum dos protozoários avaliados.

Medeiros (2010) utilizou efluente de um reator UASB e utilizou a centrifugação para concentrar as amostras. As recuperações para ensaios sem IMS, foram de 57,4\% \pm $22,4 \%$ e 3,5\% $\pm 1,1 \%$ para cistos de Giardia spp. e oocistos de Cryptosporidium spp., respectivamente, e nota-se a mesma condição abordado na presente pesquisa, somente a recuperação para cistos foi aceitável.

Ao realizar a comparação do ensaio de FCCa utilizando as suspensões (Tabela 28) e o kit Easyseed ${ }^{\circledR}$ (Tabela 29), ambos sem IMS, nota-se que ocorreu a redução de recuperação tanto para cistos quanto com oocistos. Esta condição pode estar relacionada com o número de organismos inoculados, pois não há uma proporcionalidade na concentração de (oo) cistos, conforme verificado por Giglio (2015) e também, a recuperação depende do número de organismos presentes inicialmente na amostra (BUKHARI et al., 1998).

Para os ensaios sem IMS, notou-se maior dificuldade para observar os (oo) cistos, devido as sujidades decorrentes do processo de FCCa (Figura 44). 


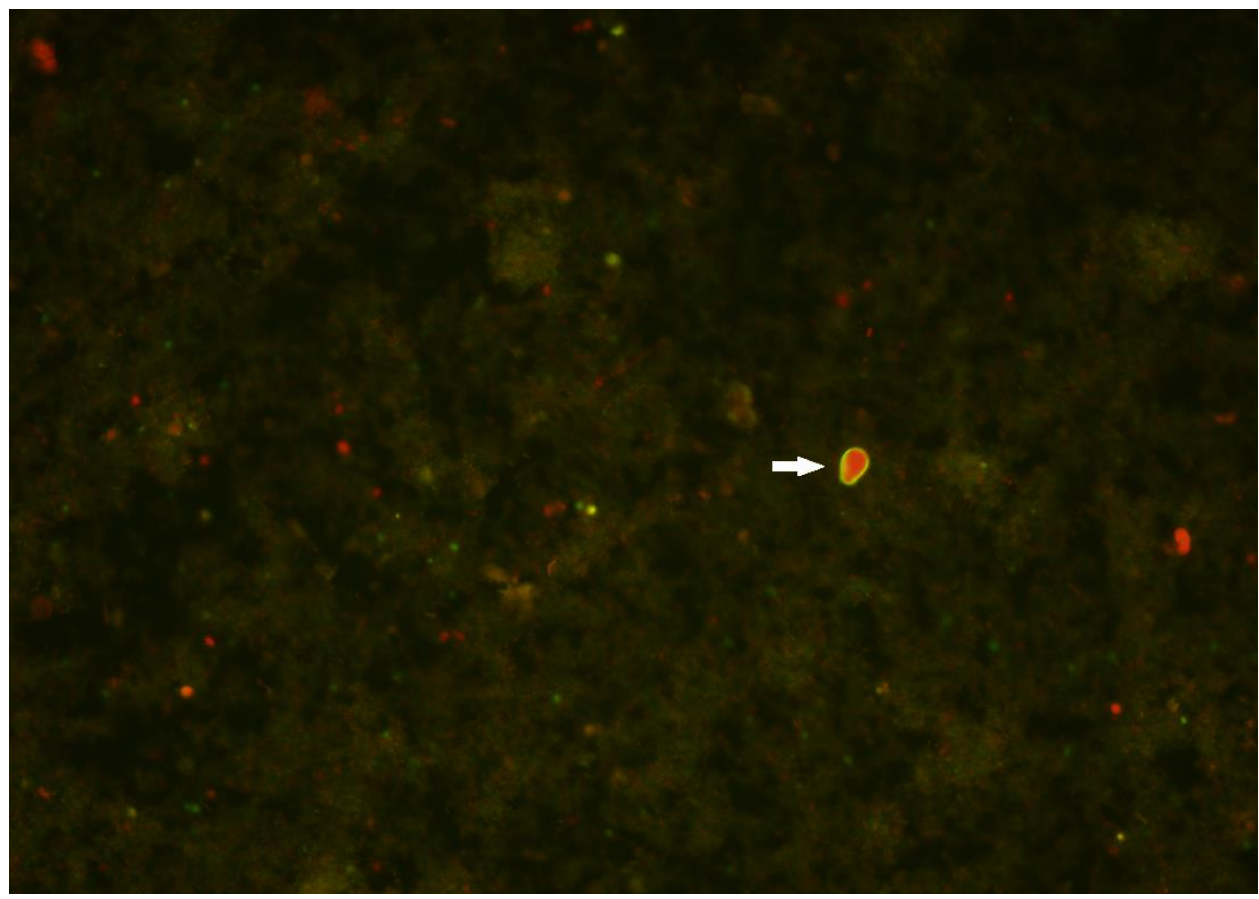

Figura 44: Sujidades observadas na lâmina do ensaio de controle de qualidade do método FCCa sem IMS.

Maciel (2014) também observou em seus ensaios sem IMS, que a qualidade da imagem visualizada na microscopia de fluorescência foi afetada pela presença de sedimentos densos, devido à água de estudo possuir turbidez aumentada por caulinita, fator este que pode inferir a possibilidade da existência de oocistos de Cryptosporidium spp. nas amostras em que eles não foram contabilizados.

Giglio (2015) reportou algumas dificuldades encontradas na leitura das lâminas, dentre elas, a presença de sujidades nos poços, que interferiam na contagem de (oo) cistos, similares com as encontradas nesta pesquisa. O método que apresentou maior dificuldade na leitura, foi uma amostra de resíduo sedimentado com inóculo na água de estudo e aplicação do método de FCCa.

Para finalizar foram realizados mais 4 ensaios e o branco, para o Método de FCCa com IMS (Tabela 30).

Tabela 30: Resultado do ensaio de qualidade analítica do protocolo de FCCa com IMS com o kit Easyseed ${ }^{\circledR}$.

\begin{tabular}{lcccccccccccccc}
\hline Protozoários & Amostra & 1 & & 2 & & 3 & & 4 \\
\hline \multirow{2}{*}{ Giardia spp. } & Dissociação & $1^{\mathrm{a}}$ & $2^{\mathrm{a}}$ & $3^{\mathrm{a}}$ & $1^{\mathrm{a}}$ & $2^{\mathrm{a}}$ & $3^{\mathrm{a}}$ & $1^{\mathrm{a}}$ & $2^{\mathrm{a}}$ & $3^{\mathrm{a}}$ & $1^{\mathrm{a}}$ & $2^{\mathrm{a}}$ & $3^{\mathrm{a}}$ \\
\cline { 2 - 13 } & Contagem de organismos & 0 & 6 & 1 & 1 & 3 & 3 & 3 & 9 & 3 & 0 & 7 & 2 \\
\hline
\end{tabular}




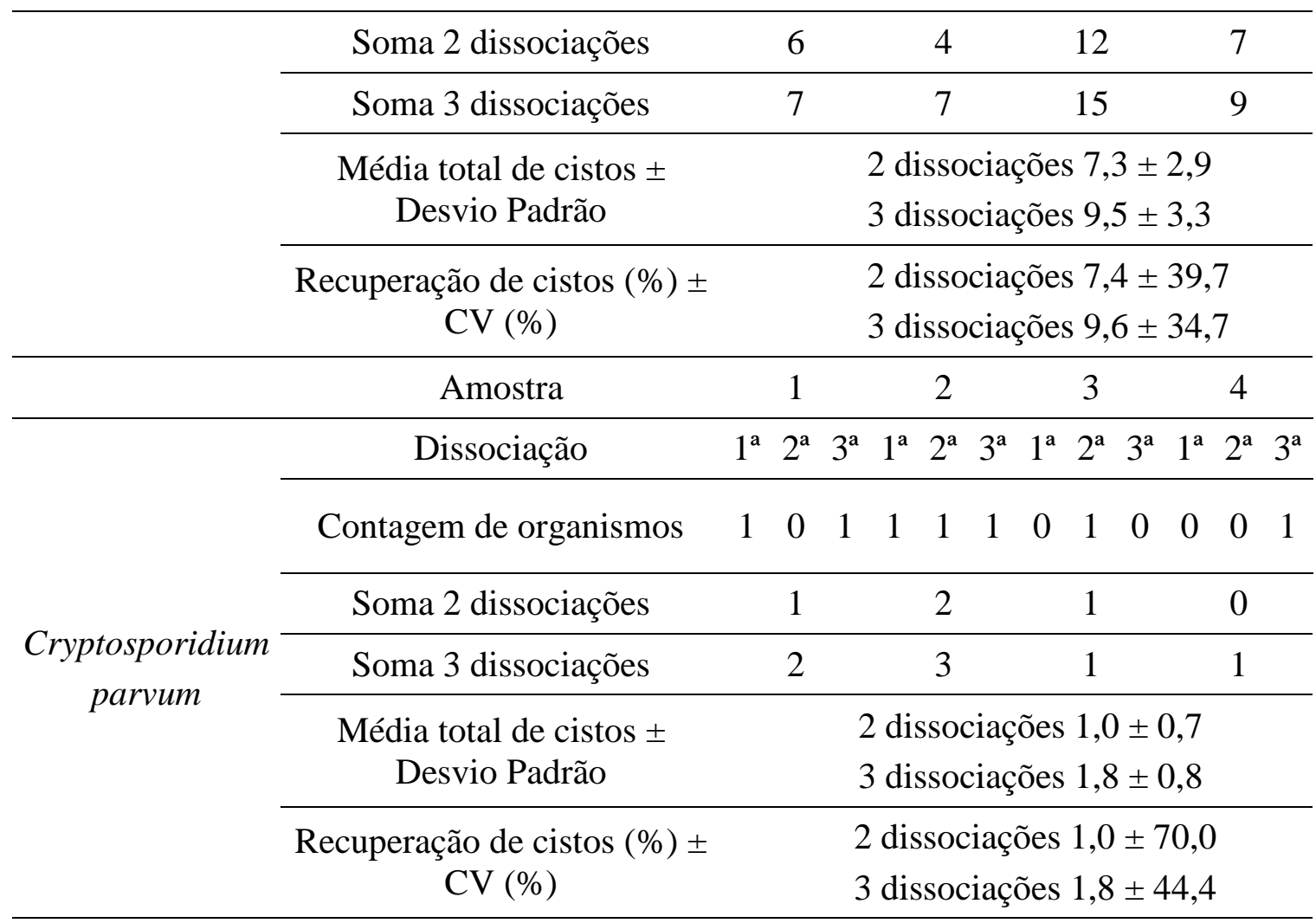

No ensaio não foram encontrados (oo) cistos na lâmina da amostra do branco, o que indica, novamente, a inexistência de contaminação no teste.

Na Tabela 30, pode-se observar que a recuperação de cistos de Giardia com 2 dissociações ácidas foi de 7,4\% $\pm 39,7 \%$ e com 3 dissociações foi de 9,6\% $\pm 34,7 \%$. Portanto, nota-se que, quando a segunda dissociação foi empregada, a recuperação não atingiu o valor estipulado pelo Método 1623.1, contudo, ao realizar a terceira dissociação, alcançou-se o valor estabelecido pelo Método.

Quando comparado com a FCCa sem IMS (Tabela 29), observa-se que, a recuperação de cistos de Giardia foi de 8,4\% \pm 97,4\% que também atendeu ao padrão estabelecido pelo Método 1623.1. Então, tanto para os ensaios sem IMS, quanto para o ensaio com IMS, mas utilizando 3 dissociações, os valores atendem ao padrão internacional.

Para os oocistos de Cryptosporidium, os valores de recuperação obtidos com o método sem IMS, foram de 3,4\% $\pm 100 \%$, e quando comparados com os ensaios com IMS, os valores encontrados foram menores, obtendo recuperação de 1,0\% $\pm 70,0 \%$ ao utilizar 2 dissociações e com 3 dissociações os valores foram de 1,8\% $\pm 44,4 \%$. Em todos os métodos, a porcentagem de recuperação para oocistos de Cryptosporidium spp. foi abaixo do critério de aceitação do Método 1623.1. 
Cantusio Neto (2008) em ensaios de FCCa com IMS realizados com água reagente inoculada artificialmente com Easyseed $^{\circledR}$, obteve taxa média de recuperação de $3,5 \% \pm 1,3(\mathrm{CV}=37,1 \%)$ para cistos de Giardia spp. e 3,6\% $\pm 3,0$ para oocistos de Cryptosporidium spp. ( $\mathrm{CV}=83,3 \%)$, ou seja, as recuperações não atingiram os valores estabelecidos no Método 1623.1 para nenhum dos protozoários avaliados.

Maciel (2014) realizou ensaios de recuperação de cistos de Giardia spp. e oocistos de Cryptosporidium spp. em testes com IMS (com duas dissociações ácidas), utilizando o método de filtração em membranas e também o kit EasySeed ${ }^{\circledR}$, para água de estudo com turbidez de 120 uT, e obteve recuperação de $31,5 \% \pm 24 \%$ e valores de 5,75 $\% \pm 55,7 \%$, para Giardia e Cryptosporidium, respectivamente, ou seja, somente a recuperação de cistos de Giardia, atendeu aos padrões estabelecidos no Método 1623.1, mesmo fato ocorrido nesta pesquisa.

Medeiros (2010) utilizou efluente de um reator UASB e concentrou as amostras por centrifugação. As recuperações para ensaios com IMS e com 2 dissociações ácidas foram de 53,1\% $\pm 29,7 \%$ para Giardia spp. e $21 \% \pm 4,9 \%$ para Cryptosporidium spp., onde somente a recuperação de Giardia spp. atendeu aos critérios estabelecidos.

Mccuin e Clancy (2003) em ensaios com amostras de água com o uso do sistema Filta-Max e IMS, alcançaram recuperações médias de 41,2\% \pm 9,9\% de Giardia duodenalis, e 50,2\% $\pm 13,8 \%$ de Cryptosporidium spp. Evidentemente, as características da matriz são fundamentais na recuperação do protocolo adotado.

Rochelle et al., (1999) relatam que o kit Dynabeads ${ }^{\circledR}$ alcançou altas recuperações na faixa de 62 a 100\% de oocistos de Cryptosporidium parvum, em amostras ambientais concentradas, obtidas a partir de filtração e centrifugação, com valores de turbidez de 210 a 11480 NTU.

Bukhari et al., (1998) utilizando centrifugação, realizaram ensaios com água deionizada, a fim de avaliar a recuperação de oocistos, e o procedimento de IMS com o kit Dynabeads, alcançaram recuperações de 68-83\%. Para amostras com turbidez em até 500 NTU, as recuperações foram semelhantes às recuperações em água deionizada. As menores recuperações foram com amostras com turbidez de 5000 NTU.

Giglio (2015), utilizando resíduo sedimentado com elevada turbidez em ensaio de qualidade do método de FCCa, empregando IMS com duas dissociações, obteve recuperações de $42 \% \pm 7 \%$ para Giardia spp. e $68 \% \pm 17 \%$ para Cryptosporidium parvum. Neste contexto de diferentes matrizes, a FCCa com IMS, mesmo com duas dissociações, aparentemente resultou melhores eficiências em amostras turvas. 
Franco et al., (2012) avaliaram três protocolos de concentração de cistos e oocistos em amostras de água bruta de rios brasileiros, que são: FCCa, filtração em membranas e filtração com o sistema Filta-Max ${ }^{\circledR}$. Na primeira etapa, cada método foi avaliado em função da recuperação e precisão e utilizaram água reagente contaminada com as suspensões do kit EasySeed ${ }^{\circledR}$ e no ensaio com a FCCa, a porcentagem média de recuperação foi de 3\% para Giardia spp. e não houve recuperação de Crypstosporidium spp.

$\mathrm{Na}$ segunda etapa, foram utilizadas amostras de águas brutas superficiais de mananciais brasileiros, a fim de analisar os interferentes na matriz e foram analisadas após a contaminação artificial com ColorSeed ${ }^{\circledR}$. A porcentagem de recuperação aumentou, atingindo valores de 39,9\% $\pm 22,1 \%$ para Giardia spp. e 26,8\% $\pm 5,3 \%$ para Cryptosporidium spp., para o manancial do Estado de Minas Gerais e de 23,8\% $\pm 10,2$ $\%$ e 2,1\% $\pm 1,0 \%$ de Giardia spp. e Crypstosporidium spp., respectivamente, para um rio do Estado de São Paulo.

Então, de acordo com FRANCO et al., (2012), fatores como este, podem ser explicados pelo fato da FCCa funcionar melhor para águas com turbidez ou com substâncias passíveis de floculação, o que não é o caso da presente pesquisa, onde a água de estudo é água filtrada e ozonizada. Outro fator relevante que justifica as baixas recuperações, é a perda de (oo) cistos durante a etapa de aspiração do sobrenadante, que devido à ausência de material floculado, os parasitos podem ser descartados.

Na Figura 45, observa-se que o poço das lâminas estava limpo, apresentando maior facilidade na leitura, devido ao uso do IMS. 


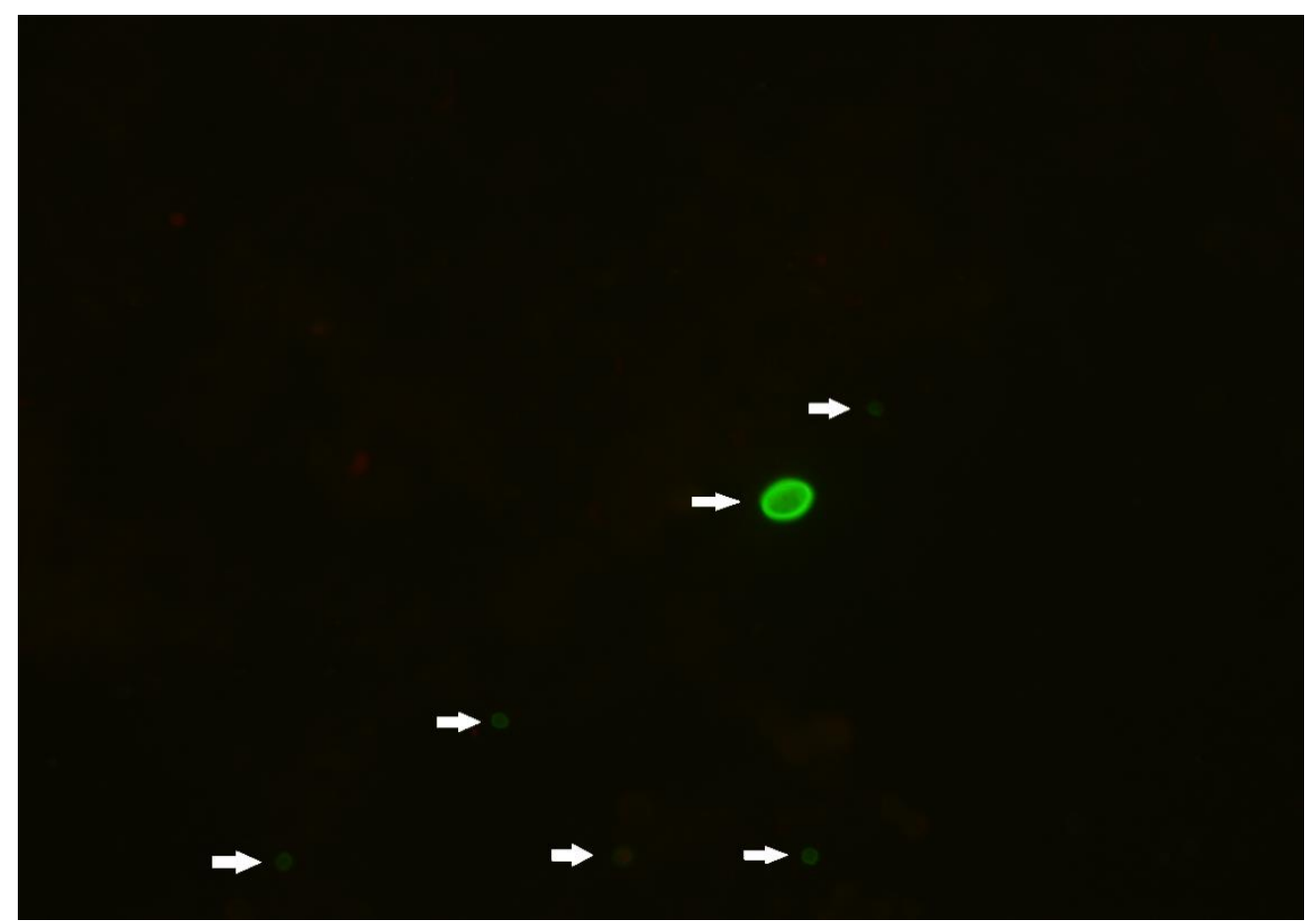

Figura 45: Imagem da visualização do poço do ensaio de controle de qualidade do método FCCa utilizando IMS.

Pode se observar na Figura 45, a visualização do poço da lâmina do ensaio com IMS, e o poço apresenta aparência límpida, sem sujidades e de fácil leitura, um dos benefícios da etapa de purificação. Maciel (2014) também relatou essa vantagem do IMS, e que não seria realizado o procedimento de identificação de protozoários sem a separação imunomagnética para amostras com muito sedimento, devido à dificuldade encontrada na leitura sem a etapa de purificação. De acordo com Maciel e Sabogal-Paz (2016) os ensaios realizados com IMS mostraram uma visão melhor dos protozoários através da leitura em microscópio.

\subsubsection{Comparação dos Métodos de FCCa sem e com IMS utilizando o kit EasySeed ${ }^{\circledR}$}

Todos os resultados do controle de qualidade analítica dos métodos avaliados para a identificação de (oo) cistos estão resumidos na Tabela 31, e efetuou-se comparações das recuperações de organismos, de acordo com os métodos testados e, também, com os critérios de qualidade para recuperação estabelecidos pelo Método 1623.1 (USEPA, 2012). 
Tabela 31: Comparação dos métodos avaliados de acordo com os critérios de qualidade para precisão e recuperação contínua (USEPA, 2012).

\begin{tabular}{lcccc}
\hline Protozoários & \multicolumn{2}{c}{ Giardia spp. } & \multicolumn{2}{c}{ Cryptosporidium parvum } \\
\hline Métodos avaliados & $\begin{array}{c}\text { Recuperação } \\
(\%)\end{array}$ & CV $(\%)$ & $\begin{array}{c}\text { Recuperação } \\
(\%)\end{array}$ & CV (\%) \\
\hline FCCa sem IMS & 8,4 & 97,4 & 3,4 & 100,0 \\
\hline $\begin{array}{l}\text { FCCa com IMS e 2 } \\
\text { dissociações }\end{array}$ & 7,4 & 39,7 & 1,0 & 70,0 \\
\hline $\begin{array}{l}\text { FCCa com IMS e 3 } \\
\text { dissociações }\end{array}$ & 9,6 & 34,7 & 1,8 & 44,4 \\
\hline Critérios EPA & $8-100$ & $\begin{array}{c}\text { Máximo } \\
39\end{array}$ & $32-100$ & $\begin{array}{c}\text { Máximo } \\
37\end{array}$ \\
\hline
\end{tabular}

Nota: Todos os ensaios foram realizados com o kit EasySeed ${ }^{\circledR}$

Ao avaliar os dados obtidos na Tabela 31, verifica-se que a FCCa com IMS e 2 dissociações não atendeu aos critérios de aceitação do Método 1623.1 (USEPA, 2012), para cistos de Giardia spp. e observa-se que, para o ensaio com IMS e três dissociações, a recuperação obteve valor ligeiramente maior em relação ao ensaio sem IMS, contudo, ambos estavam dentro dos critérios aceitos. Para oocistos de Cryptosporidium parvum nenhum método alcançou o padrão estabelecido.

Os ensaios de controle de qualidade apontaram que a melhor recuperação foi a cistos de Giardia spp. em relação aos oocistos de Cryptosporidium parvum. Este fato foi recorrente nos testes sem e com a etapa de separação imunomagnética. Maciel (2014) utilizando filtração em membranas sem e com IMS e água com elevada turbidez, protocolos diferentes aos utilizados na presente pesquisa, observou melhores recuperações quando a etapa de purificação por IMS não era empregada.

Para verificar se as diferenças entre os métodos avaliados são estatisticamente significativas, realizou-se os testes de hipóteses (teste-t: duas amostras em par para médias). As condições analisadas sobre o teste estão apresentadas na Tabela 32.

Tabela 32: Condições sobre os testes de hipóteses adotados a fim de comparar as recuperações dos métodos utilizados (FCCa sem e com IMS).

Hipótese nula $\left(\mathrm{H}_{0}\right)$ : as recuperações de (oo) cistos dos métodos não são estatisticamente diferentes, ou seja, os métodos possuem a mesma eficiência.

Hipótese alternativa $\left(\mathrm{H}_{\mathrm{a}}\right)$ : as recuperações de (oo) cistos dos métodos são estatisticamente diferentes, ou seja, um método é mais eficiente que o outro. 
n: número de amostras do ensaio de qualidade.

g: grau de liberdade (n-1).

Intervalo de confiança: $95 \%$

$\alpha$ : nível de confiança do teste $(1-$ intervalo de confiança $=5 \%)$.

Se o valor t estiver na região crítica, aceita-se $\mathrm{H}_{0}$.

Se o valor $t$ não estiver na região crítica, aceita-se $a H_{a}$.

Cada método foi avaliado para 4 amostras, assim como indicado pelo Método 1623.1 (USEPA 2012). Portanto, o grau de liberdade dos testes (g), é 3 (4-1=3), para ambos os protozoários. O nível de confiança dos testes adotado foi de 95\%. A Tabela 33 apresenta os resultados obtidos a partir da utilização do teste de hipótese.

Tabela 33: Dados utilizados para realização do teste de hipótese.

\begin{tabular}{cccc}
\hline Testes & Métodos & Protozoários & Valor-p \\
\hline \multirow{2}{*}{1} & $\begin{array}{c}\text { Sem IMS e com IMS e 2 } \\
\text { dissociações }\end{array}$ & Giardia lamblia & 0,25600733 \\
\cline { 3 - 4 } 2 & \multirow{2}{*}{$\begin{array}{c}\text { Sem IMS e com IMS e 3 } \\
\text { dissociações }\end{array}$} & Cryptosporidium parvum & 0,495025346 \\
\cline { 3 - 4 } & & Giardia lamblia & 0,119164665 \\
\hline
\end{tabular}

Nota: Todos os ensaios foram realizados com o kit Easyseed ${ }^{\circledR}$

Observando os dados apresentados na Tabela 33, o teste 1 e 2, apresentaram valores de $\mathrm{t}$ dentro da região crítica, $(\mathrm{p}>0,05)$ o que indica, que a hipótese nula deve ser aceita, que significa que as recuperações de (oo) cistos dos métodos não são estatisticamente diferentes, ou seja, os métodos possuem a mesma eficiência, para ambos os protozoários.

A determinação quanto à utilização do método de identificação de protozoários com e sem a separação imunomagnética deve avaliar alguns fatores, como, o tempo utilizado para análise, a complexidade operacional e, principalmente, a viabilidade econômica.

A realização da separação imunomagnética apresenta vantagens no sentido de que a amostra é integralmente analisada, o que dispensou analisar somente uma pequena parcela da alíquota, o que influencia nos resultados e é um potencial fator de erro. E, também, por ser uma etapa de purificação, a etapa de IMS, auxilia na leitura das 
lâminas, como visto anteriormente. Em contrapartida, o método possui vários passos, o que gera perda de (oo) cistos, resultando em baixas recuperações ao utilizar o método, como apresentado nesta pesquisa. Outra hipótese para a baixa identificação de oocistos de Cryptosporidium parvum é a dificuldade de visualização destes microrganismos na microscopia, devido ao seu tamanho reduzido.

Estas perda de (oo) cistos foram relatadas por Rochelle et al., (1999) que avaliaram 2 kits de separação imunomagnética. As perdas de oocistos foram determinadas em várias fases do processo de recuperação de ambos os métodos. Para o kit Dynal, uma porcentagem de 3,1 a 4,6\% de oocistos não foram capturados durante a separação inicial, 0,6 a 3\% permaneceram no tubo de microcentrifugação após a segunda captura e 2 a $4 \%$ de oocistos se mantiveram ligados às esferas magnéticas após a dissociação ácida.

Para realizar a comparação econômica dos métodos testados (FCCa sem e com IMS), para os testes de controle de qualidade analítica do método, o custo médio das análises foi calculado, considerando o kit Merifluor $^{\circledR}$ e o kit Easyseed $^{\circledR}$ para o método sem IMS e o acréscimo do kit Dynabeads ${ }^{\circledR}$ para o teste com IMS. Portanto, a média e o desvio padrão dos orçamentos dos produtos utilizados (Apêndice E) foram calculados, e os dados foram atualizados para abril de 2016, conforme correções do índice IGP - M (FGV) (Tabela 34).

Tabela 34: Orçamento dos materiais utilizados para uma única amostra (1 de abril de 2016).

\begin{tabular}{cccc}
\hline Produto & Merifluor $^{\circledR}$ & Dynabeads $^{\circledR}$ & Easyseed $^{\circledR}$ \\
\hline & 107,10 & 228,46 & 511,80 \\
Orçamento dos & 181,48 & 525,77 & 489,51 \\
preços unitários & 137,20 & 247,17 & 437,33 \\
(R\$) - Valor & 141,19 & 247,20 & 439,50 \\
avaliado para 1 & 161,80 & 833,13 & 429,39 \\
amostra & 112,75 & & \\
& 132,33 & & 461,51 \\
\hline Média $(\mathrm{R} \$)$ & 139,12 & 416,35 & 32,91 \\
\hline DP & 24,15 & 235,89 &
\end{tabular}

Na Tabela 34 pode-se observar os dados econômicos apresentados, entre os materiais utilizados, o kit Merifluor ${ }^{\circledR}$ é o que apresenta menor custo médio por aplicação e o kit Easyseed ${ }^{\circledR}$ é o que possui o valor mais elevado. O kit Dynabeads ${ }^{\circledR}$ é o que possui 
maior variedade de custo entre os orçamentos citados (alto desvio padrão), e isto é explicado devido ao tamanho dos kits, por exemplo, uns possuem 10 ou 50 amostras.

Então, a partir do custo unitário de cada produto, foi possível calcular o custo médio de cada ensaio de qualidade, para realizar a comparação dos métodos avaliados.

O cálculo foi realizado individualmente para cada método, considerando a quantidade de produto utilizada em cada teste, e 4 ensaios para cada método realizados em triplicata, que foram: i) ensaio de FCCa sem IMS: 4 unidades do Easyseed $^{\circledR}$ e 12 ${\text { unidades do } \text { kit } \text { Merifluor }}^{\circledR}$; ii) ensaio de FCCa com IMS e 2 dissociações: 4 unidades do Easyseed $^{\circledR}, 4$ unidades do kit Dynadeads $^{\circledR}$ e 8 unidades do kit $^{\text {Merifluor }}{ }^{\circledR}$ e iii) ensaio

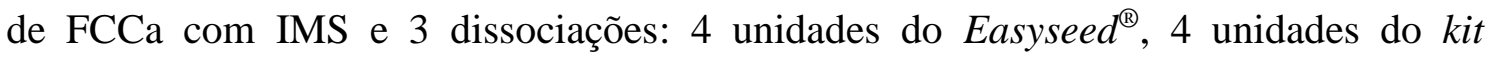
Dynabeads $^{\circledR}$ e 12 unidades do kit Merifluor ${ }^{\circledR}$ (Tabela 35).

Tabela 35: Custo médio do ensaio de controle de qualidade analítica do método de FCCa sem IMS, FCCa com IMS utilizando 2 e 3 dissociações, com dados atualizados utilizando o índice IGP-M (FGV) (1 de abril de 2016).

\begin{tabular}{cc}
\hline Método & Valor médio de cada ensaio de qualidade (R\$) \\
\hline FCCa sem IMS & $3515,50 \pm 421,47$ \\
\hline FCCa com IMS e 2 dissociações & $4624,40 \pm 1268,42$ \\
\hline FCCa com IMS e 3 dissociações & $5180,90 \pm 1365,03$ \\
\hline
\end{tabular}

Pelos valores apresentados na Tabela 35, observa-se que o método de FCCa com IMS utilizando duas dissociações ácidas tem custo $24 \%$ maior do que o custo do método sem IMS, e 32\% maior quando comparado com três dissociações. Ao comparar os testes com IMS, nos ensaios empregando a terceira dissociação ácida, o aumento é de $10,7 \%$ em relação aos ensaios com duas dissociações.

Depois de analisar os resultados das análises estatísticas dos ensaios de recuperação e dos custos envolvidos entre os métodos avaliados, é possível afirmar que o método de FCCa sem IMS é o mais viável, por ser o mais econômico e com melhor recuperação do que o método de FCCa com IMS e não apresenta diferenças significativas quando comparado ao ensaio com IMS, mesmo quando a terceira dissociação é empregada, a diferença entre os métodos não é estatisticamente significativa.

\subsection{Ensaio de Ozonização}


Para iniciar os ensaios de ozonização, foi necessário calcular a produção de ozônio que seria utilizada para as duas etapas. Para isto, utilizou-se a Equação 11 descrita no Item 4.12.2.2. Para a Etapa 1, a dosagem foi fixada em $5 \mathrm{mgO}_{3} \mathrm{~L}^{-1}$ e o tempo de contato de 1 min, e então, calculou-se a produção necessária para realizar o ensaio.

Após o cálculo, obteve-se valor de produção de $0,9 \mathrm{gO}_{3} \mathrm{~h}^{-1}$, que, pela Tabela 2 do Item 4.12.2.3, optou-se por escolher a produção de $0,63 \mathrm{gO}_{3} \mathrm{~h}^{-1}$ (valor aproximado do valor desejado) que corresponde à uma tensão do aparelho de $60 \%$ e vazão de ar de 1 L.min ${ }^{-1}$. No mesmo item, na Figura 8, foram obtidas as equações que relacionam a vazão de ozônio com a produção do mesmo, para cada tensão utilizada, ou seja, colocando os valores obtidos, encontrava-se a curva de produção que mais se aproximava dos valores desejados, que nesta etapa, foi definida pela curva de $60 \%$ (Equação 20).

$P_{60 \%}=0,4275 Q^{1,8924}$ e valor de $\mathrm{R}^{2}=0,9062$.

Equação 20

Em que:

$\mathrm{P}_{60 \%}=$ Produção de ozônio $\left(\mathrm{gO}_{3} \mathrm{~h}^{-1}\right)$ e $\mathrm{Q}=$ Vazão de $\operatorname{ar}\left(\mathrm{L} \cdot \mathrm{min}^{-1}\right)$.

Para a Etapa 2, o mesmo procedimento foi realizado, agora para a mesma dosagem utilizada e tempo de contato de $5 \mathrm{~min}$. Obteve-se valor de produção de 0,18 $\mathrm{gO}_{3} \mathrm{~h}^{-1}$, que através da Tabela 2 do Item 4.12.2.3, optou-se por escolher a produção de $0,09 \mathrm{gO}_{3} \mathrm{~h}^{-1}$ (valor aproximado do valor desejado) que corresponde à uma tensão do aparelho de $60 \%$ e vazão de ar de $0,5 \mathrm{~L} \cdot \mathrm{min}^{-1}$. A curva de produção obtida para esta segunda etapa, foi a mesma curva de 60\%, utilizada na Etapa 1 (Equação 20).

\subsubsection{Etapa 1 - Ensaios de Desinfecção Sem a Etapa de IMS}

Primeiramente, antes de dar início aos ensaios de ozonização, um ensaio foi realizado para efetuar a contagem dos (oo) cistos, a fim de conhecer o número de protozoários a serem inoculados na amostra de água filtrada (Tabela 36) e, também, para estimar a viabilidade dos organismos alvos antes da desinfecção (Tabela 37). 
Tabela 36: Determinação do valor e concentração do inóculo a ser utilizado para os 3 L de água filtrada para o ensaio de ozonização para as suspensões de Giardia spp. e Cryptosporidium parvum para a primeira etapa.

\begin{tabular}{|c|c|c|c|c|c|c|c|}
\hline Suspensão & $\begin{array}{l}\text { Poço da } \\
\text { lâmina }\end{array}$ & $\begin{array}{c}\text { Alíquota } \\
(\mu \mathrm{L})\end{array}$ & $\begin{array}{c}\text { Contagem } \\
\text { de (oo) } \\
\text { cistos }\end{array}$ & $\begin{array}{l}\text { Média de } \\
\text { (oo) cistos } \\
\pm \text { DP ou } \pm \\
\text { CV }(\%)\end{array}$ & $\begin{array}{c}\text { Volume do } \\
\text { inóculo } \\
\text { para os } 3 \mathrm{~L} \\
\text { de amostra } \\
\quad(\mu \mathrm{L})\end{array}$ & $\begin{array}{c}\text { Inóculo para } \\
\text { os } 3 \mathrm{~L} \mathrm{de} \\
\text { amostra } \\
\left.\text { [(oo)cistos.L } \text { L }^{-1}\right]\end{array}$ & $\begin{array}{c}\text { Total } \\
\text { de } \\
\text { (oo) } \\
\text { ] cistos }\end{array}$ \\
\hline \multirow{3}{*}{ Giardia spp. } & 1 & & 410 & $444 \pm$ & & & \\
\hline & 2 & 5 & 435 & $32 \mathrm{ou} \pm$ & 150 & 4440 & 13320 \\
\hline & 3 & & 487 & 7 & & & \\
\hline \multirow{3}{*}{$\begin{array}{c}\text { Cryptosporidium } \\
\text { parvum }\end{array}$} & 1 & & 357 & $374 \pm$ & & & \\
\hline & 2 & 5 & 315 & 57 ou \pm & 150 & 3744 & 11230 \\
\hline & 3 & & 451 & 15 & & & \\
\hline
\end{tabular}

Portanto, após a realização do ensaio, como o objetivo era inocular cerca de 30.000 parasitos (15.000 cistos de Giardia spp. e 15.000 oocistos de Cryptosporidium parvum) para os $3 \mathrm{~L}$ de amostra, encontrou-se o valor de $150 \mu \mathrm{L}$ de cada parasito para a inoculação, que apresentava um valor próximo ao estipulado.

Tabela 37: Dados obtidos a partir de ensaios de viabilidade do inóculo da suspensão de Giardia spp. e Cryptosporidium parvum para a primeira etapa.

\begin{tabular}{l|ccc|ccc}
\hline Protozoário & \multicolumn{3}{|c|}{ Giardia spp. } & \multicolumn{3}{c}{ Cryptosporidium parvum } \\
\hline Poço da lâmina & 1 & 2 & 3 & 1 & 2 & 3 \\
\hline $\begin{array}{l}\text { (oo) cistos inviáveis } \\
\text { (corados) }\end{array}$ & 312 & 340 & 345 & 281 & 274 & 427 \\
\hline $\begin{array}{l}\text { (oo) cistos viáveis } \\
\text { (não corados) }\end{array}$ & 98 & 95 & 142 & 76 & 41 & 24 \\
\hline Inviáveis (\%) & 76,1 & 78,2 & 70,8 & 78,7 & 86,9 & 94,7 \\
\hline Média/DP & \multicolumn{3}{|c|}{$75 / 3,08$} & & \multicolumn{3}{c}{$86,8 / 6,52$} \\
\hline Viáveis (\%) & 23,9 & 21,8 & 29,2 & 21,3 & 13,0 & 5,3 \\
\hline Média/DP & \multicolumn{3}{|c|}{$25 / 3,08$} & & \multicolumn{3}{c}{$13,2 / 6,52$} \\
\hline
\end{tabular}

Observando os dados apresentados na Tabela 37, nota-se que a suspensão apresentava $75 \%$ de cistos de Giardia spp. corados e $25 \%$ de cistos não corados. Para a suspensão de Cryptosporidium parvum, $86,8 \%$ são de oocistos corados e 13,2\% de oocistos não corados. 
A contagem dos protozoários e a estimativa da viabilidade foram realizados antes de iniciar cada etapa e o resultado foi utilizado para os seis ensaios seguintes.

A etapa 1, com FCCa sem IMS, apresenta algumas vantagens, como na questão financeira, já que o custo médio de 1 kit Dynabeads ${ }^{\circledR}$ utilizado no procedimento de purificação, no Brasil é de US\$ 5.000,00, e um kit é suficiente para apenas 50 amostras (cotação obtida em junho de 2015) (MACIEL; SABOGAL-PAZ, 2016). Outro benefício, é a demanda de menor tempo laboratorial, já que o procedimento de IMS envolve vários passos e requer pessoas treinadas e qualificadas para manusear o kit, evitando assim, perdas e erros.

\subsubsection{Primeira Parte da Etapa 1}

Primeiramente, foram medidos a cor aparente, turbidez, $\mathrm{pH}$ e a temperatura, para então, iniciar o ensaio. Ao final do ensaio, os mesmos parâmetros medidos inicialmente, foram repetidos (Tabela 38). A primeira etapa, FCCa sem IMS, foi realizada com dosagem definida de ozônio de $5 \mathrm{mg} . \mathrm{L}^{-1}$ e tempo de contato de $1 \mathrm{~min}$, e foi realizado em triplicata e os resultados serão descritos a seguir.

Tabela 38: Caracterização da água filtrada antes da desinfecção e após a ozonização dos 3 ensaios com $5 \mathrm{mgO}_{3} \mathrm{~L}^{-1}$ e tempo de contato de 1 min e sem IMS.

\begin{tabular}{lccccc}
\hline Condição & Ensaios & Turbidez $(\mathrm{uT})$ & Cor aparente $(\mathrm{uC})$ & Temperatura $\left({ }^{\circ} \mathrm{C}\right)$ & $\mathrm{pH}$ \\
\hline Antes do ensaio & \multirow{2}{*}{1} & 0,2 & 2,3 & 20 & 7 \\
Depois do ensaio & & 0,2 & 1,7 & 22 & 7,22 \\
\hline Antes do ensaio & \multirow{2}{*}{2} & 0,1 & 1,4 & 22 & 7,08 \\
Depois do ensaio & & 0,2 & 0,6 & 23 & 7,3 \\
\hline Antes do ensaio & \multirow{2}{*}{3} & 0,1 & 1,1 & 22 & 7,06 \\
Depois do ensaio & & 0,2 & 0,8 & 23 & 7,3 \\
\hline
\end{tabular}

Na primeira parte da etapa 1, nota-se que o valor de turbidez para os 3 ensaios se manteve constante até o final do ensaio, e a cor aparente diminuiu. A temperatura ambiente ficou entre 20 e $23^{\circ} \mathrm{C}$. 
As eficiências médias na transferência de massa de ozônio, a concentração média de ozônio no off-gas, no ozônio residual dissolvido e no ozônio consumido são apresentadas na Tabela 39.

Tabela 39: Concentrações de ozônio aplicado, ozônio do off-gas, ozônio residual dissolvido, ozônio consumido e eficiências na transferência de massa de ozônio para as dosagens de $5 \mathrm{mgO}_{3} \mathrm{~L}^{-1}$ e tempo de contato de 1 min sem IMS.

\begin{tabular}{ccccccc}
\hline Ensaios & $\begin{array}{c}\text { Ozônio } \\
\text { aplicado } \\
\left(\mathrm{mgO}_{3} \mathrm{~L}^{-1}\right)\end{array}$ & $\begin{array}{c}\text { Tempo } \\
\text { contato } \\
(\mathrm{min})\end{array}$ & $\begin{array}{c}\text { Ozônio do } \\
\text { off-gas } \\
\left(\mathrm{mgO}_{3} \mathrm{~L}^{-1}\right)\end{array}$ & $\begin{array}{c}\text { Ozônio } \\
\text { residual } \\
\text { dissolvido } \\
\left(\mathrm{mgO}_{3} \mathrm{~L}^{-1}\right)\end{array}$ & $\begin{array}{c}\text { Ozônio } \\
\text { consumido } \\
\left(\mathrm{mgO}_{3} \mathrm{~L}^{-1}\right)\end{array}$ & $\begin{array}{c}\text { Ozônio } \\
\text { transferido }\end{array}$ \\
\hline 1 & 5 & 1 & 0,6 & $-0,06^{(1)}$ & 4,46 & 89,2 \\
2 & 5 & 1 & 2,64 & $-0,05^{(2)}$ & 2,41 & 48,2 \\
3 & 5 & 1 & 2,97 & $-0,05^{(3)}$ & 2,07 & 41,4 \\
\hline
\end{tabular}

Nota: ${ }^{(1),(2) \text { e (3) }}=$ valores abaixo da faixa de medição.

A eficiência na transferência de massa (quantidade de ozônio consumida em relação ao ozônio aplicado) foi obtida a partir da média dos ensaios 1, 2 e 3 (Tabela 39), e obteve valor médio de 59,6\% para a dosagem de $5 \mathrm{mgO}_{3} \mathrm{~L}^{-1}$ e tempo de $1 \mathrm{~min}$, que será discutido no Item 5.7.3.

Na Tabela 40 estão apresentados os dados obtidos da desinfecção de Giardia spp. e de Cryptosporidium parvum em $\log _{10}$ para a dosagem de $5 \mathrm{mgO}_{3} \mathrm{~L}^{-1}$ e tempo de contato de $1 \mathrm{~min}$.

Tabela 40: Inativação em $\log _{10}$ de Giardia spp. e Cryptosporidium parvum em relação à dosagem de $5 \mathrm{mgO}_{3} \mathrm{~L}^{-1}$, tempo de contato de 1 min e concentração de ozônio consumido.

\begin{tabular}{ccccccc}
\hline & \multicolumn{2}{c}{ Água com inóculo } & \multicolumn{2}{c}{ Amostra ozonizada } & \multicolumn{2}{c}{ Inativação em $\log _{10}$} \\
Ensaio & & Cryptosporidium & Giardia & Cryptosporidium & Giardia & Cryptosporidium \\
& Giardia spp. & parvum & spp. & parvum & spp. & parvum \\
\hline 1 & 13320 & 11230 & 86 & 2386 & 2,19 & 0,67 \\
2 & 13320 & 11230 & 40 & 106 & 2,52 & 2,02 \\
3 & 13320 & 11230 & 93 & 66 & 2,15 & 2,22 \\
\hline
\end{tabular}


No ensaio 2, obteve-se 2,52 log de inativação, sendo o maior valor encontrado para Giardia spp. e o ensaio 3, apresentou 2,22 log de inativação para Cryptosporidium parvum. As menores desinfecções foram no ensaio 3, com 2,15 $\log$ de inativação e no ensaio 1, com 0,67 log de inativação para Giardia spp. e Cryptosporidium parvum, respectivamente.

Os dados de recuperação para a primeira parte da etapa 1 sem IMS estão apresentados na Tabela 41.

Tabela 41: Dados de recuperação dos métodos empregados de Giardia spp. e Cryptosporidium parvum para a primeira parte da etapa 1 , com dosagem de $5 \mathrm{mgO}_{3} \mathrm{~L}^{-1}$, tempo de contato de 1 min e sem IMS.

\begin{tabular}{|c|c|c|c|c|}
\hline Protozoário & Ensaio & 1 & 2 & 3 \\
\hline \multirow{7}{*}{ Giardia spp. } & Poço das lâminas & 2 & 23 & 123 \\
\hline & Inóculo na amostra & 13320 & 13320 & 13320 \\
\hline & Contagem de organismos & $\begin{array}{lll}5 & 4 & 4\end{array}$ & $\begin{array}{lll}1 & 5 & 0\end{array}$ & 257 \\
\hline & Contagem total & 13 & 6 & 14 \\
\hline & FM & 6,67 & 6,67 & 6,67 \\
\hline & Recuperação (\%) & 0,65 & 0,3 & 0,7 \\
\hline & \multicolumn{2}{|l|}{ Recuperação total (\%) } & \multicolumn{2}{|l|}{0,65} \\
\hline \multirow{7}{*}{$\begin{array}{c}\text { Cryptosporidium } \\
\text { parvum }\end{array}$} & Poço das lâminas & 2 & 23 & 123 \\
\hline & Inóculo na amostra & 11230 & 11230 & 11230 \\
\hline & Contagem de organismos & $\begin{array}{lll}134 & 85 & 139\end{array}$ & 70 & 217 \\
\hline & Contagem total & 358 & 16 & 10 \\
\hline & FM & 6,67 & 6,67 & 6,67 \\
\hline & Recuperação (\%) & 21,26 & 0,95 & 0,59 \\
\hline & \multicolumn{2}{|l|}{ Recuperação total (\%) } & \multicolumn{2}{|l|}{7,6} \\
\hline
\end{tabular}

Observando os dados apresentados na Tabela 41, nota-se que a recuperação de cistos foi extremamente baixa, apresentando valor de 0,65\%. Para os oocistos, a recuperação foi de $7,6 \%$, valor maior, porém, ainda não o suficiente. O método contou com baixas recuperações, mesmo utilizando $\mathrm{FM}=6,67$. Os valores baixos de recuperação podem ser devido ao descarte do sobrenadante contendo os protozoários na 
etapa da FCCa, pela perda dos parasitos na coluna de ozonização, devido à pouca fração de amostra, obtida na centrifugação, que é analisada, ou seja, apenas $150 \mu \mathrm{L}$ de um total de $1000 \mu \mathrm{L}$, e, principalmente, pela desinfecção com o ozônio, que pode ter danificado e/ou destruído a estrutura dos parasitos.

Medeiros (2010) também reportou esta condição, onde não foram encontrados (oo) cistos nas amostras desinfetadas com ozônio.

Os valores da estimativa de viabilidade utilizando o IP para os ensaios da primeira parte da etapa 1 estão demonstrados na Tabela 42. Os dados apresentados são referentes aos mostrados na Tabela 41, a partir da contagem dos organismos, onde foram avaliados como não corados ou corados e a porcentagem de cada um deles.

Tabela 42: Porcentagem dos organismos viáveis (não corados) e inviáveis (corados) referentes à primeira parte da etapa 1 .

\begin{tabular}{|c|c|c|c|c|}
\hline Protozoário & Ensaio & 1 & 2 & 3 \\
\hline \multirow{5}{*}{ Giardia spp. } & Poço da lâmina & $\begin{array}{lll}1 & 2 & 3\end{array}$ & $\begin{array}{lll}1 & 2 & 3\end{array}$ & 1223 \\
\hline & Cistos inviáveis (corados) & $\begin{array}{lll}5 & 4 & 4\end{array}$ & \begin{tabular}{lll|}
1 & 5 & 0
\end{tabular} & 257 \\
\hline & Cistos viáveis (não corados) & $\begin{array}{lll}0 & 0 & 0\end{array}$ & $\begin{array}{lll}0 & 0 & 0\end{array}$ & $\begin{array}{lll}0 & 0 & 0\end{array}$ \\
\hline & \% cistos inviáveis (corados) & 100 & 100 & 100 \\
\hline & \% cistos viáveis (não corados) & 0 & 0 & 0 \\
\hline \multirow{5}{*}{ Cryptosporidium parvum } & Poço da lâmina & 23 & $\begin{array}{lll}1 & 2 & 3\end{array}$ & 123 \\
\hline & Oocistos inviáveis (corados) & $\begin{array}{lll}127 & 83 & 136\end{array}$ & $\begin{array}{lll}6 & 5 & 0\end{array}$ & 207 \\
\hline & Oocistos viáveis (não corados) & 3 & $\begin{array}{lll}3 & 2 & 0\end{array}$ & $\begin{array}{lll}0 & 1 & 0\end{array}$ \\
\hline & \% oocistos inviáveis (corados) & 96,75 & 69 & 66,7 \\
\hline & \% oocistos viáveis (não corados) & 3,25 & 31 & 33,3 \\
\hline
\end{tabular}

Nota-se que no primeiro ensaio de estimativa de viabilidade após a ozonização, $100 \%$ dos cistos de Giardia estavam corados (inviáveis), e para os oocistos, uma média de $77,5 \%$ dos organismos estavam corados (inviáveis). Com estes dados, pode se dizer, que o tempo de desinfecção de 1 min, não foi suficiente para tornar todos os organismos inviáveis, devido aos resultados encontrados nos três primeiros ensaios utilizando este tempo de contato, apresentar razoável quantidade de oocistos sem a inclusão do corante.

Os resultados aqui apresentados serão discutidos no Item 5.7.4, juntamente com a segunda parte da Etapa 1, descrita a seguir. 


\subsubsection{Segunda Parte da Etapa 1}

Os dados obtidos a partir dos ensaios de caracterização da água de estudo e da amostra ozonizada estão descritos na Tabela 43.

Tabela 43: Caracterização da água filtrada antes da desinfecção e após a ozonização dos 3 ensaios com $5 \mathrm{mgO}_{3} \mathrm{~L}^{-1}$ e tempo de contato de 5 min e sem IMS.

\begin{tabular}{lccccc}
\hline Condição & Ensaios & Turbidez $(\mathrm{uT})$ & Cor aparente $(\mathrm{uC})$ & Temperatura $\left({ }^{\circ} \mathrm{C}\right)$ & $\mathrm{pH}$ \\
\hline Antes do ensaio & \multirow{2}{*}{1} & 0,2 & 1 & 21 & 7,07 \\
Depois do ensaio & & 0,2 & 0 & 25 & 7,40 \\
\hline Antes do ensaio & \multirow{2}{*}{2} & 0,1 & 1,4 & 23 & 7,04 \\
Depois do ensaio & & 0,2 & 0,2 & 24 & 7,16 \\
\hline Antes do ensaio & \multirow{2}{*}{3} & 0,1 & 2,6 & 24 & 7,27 \\
Depois do ensaio & & 0,1 & 1,8 & 27 & 7,23 \\
\hline
\end{tabular}

Observando os dados apresentados na Tabela 43, a mesma condição apontada no Item 5.7.1.1 para esta parte da etapa se repete. Os valores de turbidez permaneceram constantes e a cor aparente diminuiu. A temperatura permaneceu na faixa de 21 a $27^{\circ} \mathrm{C}$.

E igualmente, as eficiências médias na transferência de massa de ozônio, a concentração média de ozônio no off-gas, no ozônio residual dissolvido e no ozônio consumido são apresentados na Tabela 44.

Tabela 44: Concentrações de ozônio aplicado, ozônio do off-gas, ozônio residual dissolvido, ozônio consumido e eficiências na transferência de massa de ozônio para as dosagens de $5 \mathrm{mgO}_{3} \mathrm{~L}^{-1}$ e tempo de contato de 5 min sem IMS.

\begin{tabular}{ccccccc}
\hline Ensaios & $\begin{array}{c}\text { Ozônio } \\
\text { aplicado } \\
\left(\mathrm{mgO}_{3} \mathrm{~L}^{-1}\right)\end{array}$ & $\begin{array}{c}\text { Tempo } \\
\text { de } \\
\text { contato } \\
(\min )\end{array}$ & $\begin{array}{c}\text { Ozônio do } \\
\text { off-gas } \\
\left(\mathrm{mgO}_{3} \mathrm{~L}^{-1}\right)\end{array}$ & $\begin{array}{c}\text { Ozônio } \\
\text { residual } \\
\text { dissolvido } \\
\left(\mathrm{mgO}_{3} \mathrm{~L}^{-1}\right)\end{array}$ & $\begin{array}{c}\text { Ozônio } \\
\text { consumido } \\
\left(\mathrm{mgO}_{3} \mathrm{~L}^{-1}\right)\end{array}$ & $\begin{array}{c}\text { Ozônio } \\
\text { transferido } \\
(\%)\end{array}$ \\
\hline 1 & 5 & 5 & 2,3 & 0,35 & 2,35 & 47,0 \\
2 & 5 & 5 & 2,3 & 0,27 & 2,43 & 48,6
\end{tabular}


Observando os dados mostrados na Tabela 44, a eficiência na transferência de massa, a partir da média realizada com os ensaios 1, 2 e 3, obteve-se o valor de 58,3\% para a dosagem de $5 \mathrm{mgO}_{3} \mathrm{~L}^{-1}$ e tempo de 5 min.

Na Tabela 45, estão apresentados os dados obtidos da desinfecção de Giardia spp. e Cryptosporidium parvum em $\log _{10}$ para a dosagem de $5 \mathrm{mgO}_{3} \mathrm{~L}^{-1}$ e tempo de contato de $5 \mathrm{~min}$.

Tabela 45: Inativação em $\log _{10}$ de Giardia spp. e Cryptosporidium parvum em relação à dosagem de $5 \mathrm{mgO}_{3} \mathrm{~L}^{-1}$, tempo de contato de $5 \mathrm{~min}$ e concentração de ozônio consumido.

\begin{tabular}{ccccccc}
\hline & \multicolumn{2}{c}{ Água com inóculo } & \multicolumn{2}{c}{ Amostra ozonizada } & \multicolumn{2}{c}{ Inativação em $\log _{10}$} \\
Ensaio & Giardia & Cryptosporidium & Giardia & Cryptosporidium & Giardia & Cryptosporidium \\
& spp. & parvum & spp. & parvum & spp. & parvum \\
\hline 1 & 13320 & 11230 & 46 & 13 & 2,45 & 2,92 \\
2 & 13320 & 11230 & 40 & 13 & 2,52 & 2,92 \\
3 & 13320 & 11230 & 46 & 0 & 2,45 & - \\
\hline
\end{tabular}

No ensaio 2, obteve-se 2,52 log de inativação, sendo o maior valor encontrado para Giardia spp. e o mesmo obtido no Item 5.7.1.1 e o ensaio 1 e 2, apresentaram a mesma inativação de 2,92 log de inativação para Cryptosporidium parvum. As menores desinfecções foram no ensaio 1 e 3 , com o mesmo valor de 2,45 log de inativação de cistos de Giardia spp. e no ensaio 3, onde não foi encontrado nenhum oocistos de Cryptosporidium parvum.

Os dados de recuperação de Giardia spp. e Cryptosporidium parvum para a segunda parte da etapa 1 sem IMS, estão apresentados na Tabela 46. 
Tabela 46: Dados de recuperação dos métodos empregados de Giardia spp. e Cryptosporidium parvum para a segunda parte da etapa 1 , com dosagem de $5 \mathrm{mgO}_{3} \mathrm{~L}^{-1}$, tempo de contato de 5 min e sem IMS.

\begin{tabular}{|c|c|c|c|c|}
\hline Protozoário & Ensaio & 1 & 2 & 3 \\
\hline \multirow{7}{*}{ Giardia spp. } & Poço das lâminas & 123 & 123 & 123 \\
\hline & Inóculo na amostra & 13320 & 13320 & 13320 \\
\hline & Contagem de organismos & $\begin{array}{lll}0 & 5 & 2\end{array}$ & $\begin{array}{lll}2 & 3 & 1\end{array}$ & 322 \\
\hline & Contagem total & 7 & 6 & 7 \\
\hline & FM & 6,67 & 6,67 & 6,67 \\
\hline & Recuperação (\%) & 0,35 & 0,3 & 0,35 \\
\hline & Recuperação total (\%) & \multicolumn{3}{|c|}{0,33} \\
\hline \multirow{7}{*}{ Cryptosporidium parvum } & Poço das lâminas & 123 & 123 & 123 \\
\hline & Inóculo na amostra & 11230 & 11230 & 11230 \\
\hline & Contagem de organismos & $\begin{array}{lll}0 & 2 & 0\end{array}$ & $\begin{array}{lll}1 & 0 & 1\end{array}$ & $\begin{array}{lll}0 & 0 & 0\end{array}$ \\
\hline & Contagem total & 2 & 2 & 0 \\
\hline & $\mathrm{FM}$ & 6,67 & 6,67 & 6,67 \\
\hline & Recuperação (\%) & 0,12 & 0,12 & $\mathrm{NC}$ \\
\hline & \multicolumn{2}{|l|}{ Recuperação total (\%) } & 0,08 & \\
\hline
\end{tabular}

Observando os dados apresentados na Tabela 46, nota-se que as recuperações são ainda mais baixas, quando comparadas com os valores obtidos no ensaio anterior (Item 5.7.1.1). Este fato pode ser explicado pelos motivos já citados, aliado ao fato de que, o tempo de contato para esses ensaios foi maior, $5 \mathrm{~min}$, o que pode ter influenciado na baixa recuperação, pela possível deterioração dos (oo) cistos.

A porcentagem dos parasitos que penetraram ou expulsaram o corante está apresentada na Tabela 47, com base nos resultados obtidos da Tabela 46. 
Tabela 47: Porcentagem dos organismos não corados e corados referentes à segunda parte da etapa 1.

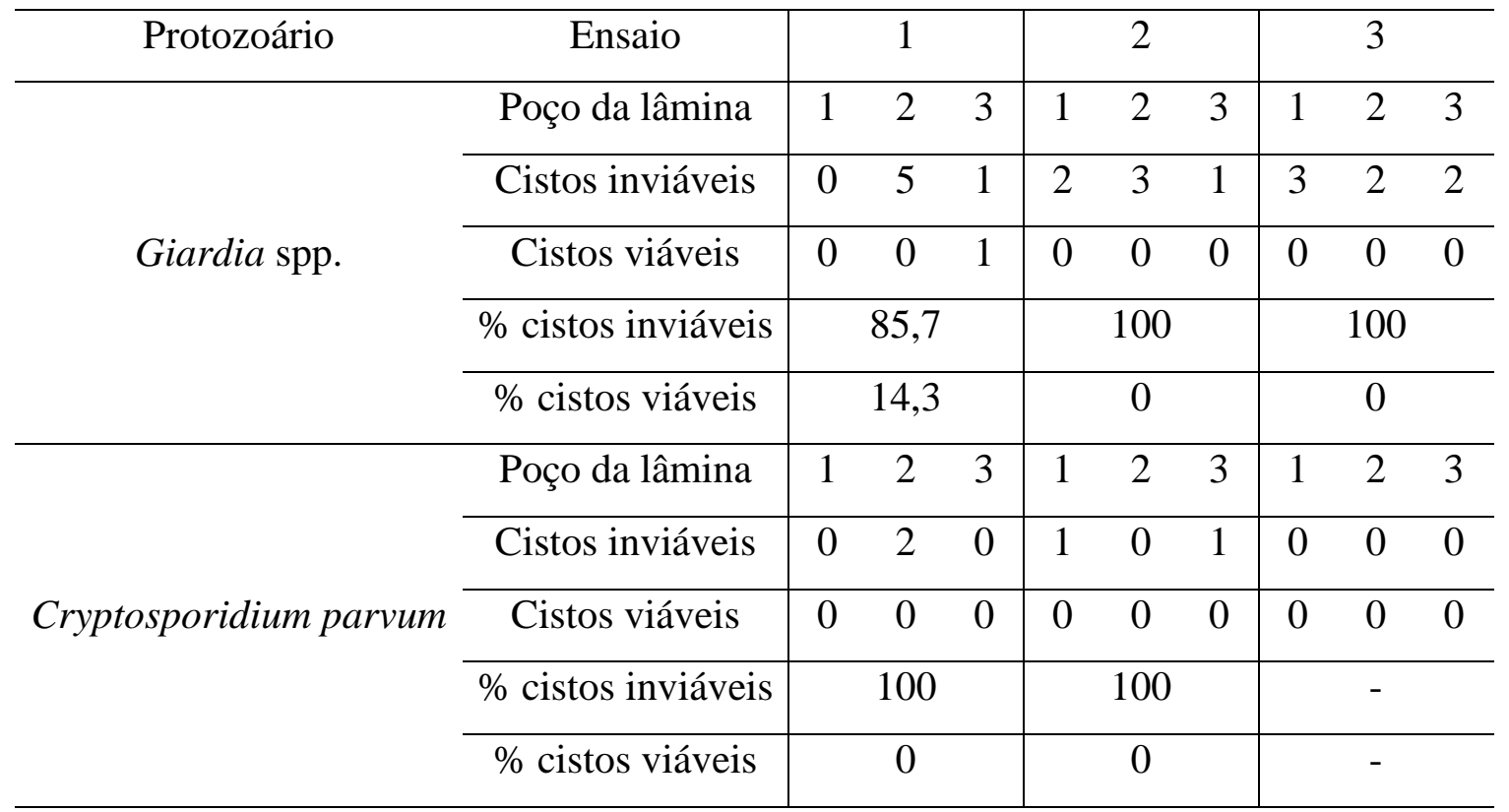

Nota: - = ausência de (oo) cistos.

Pelos dados apresentados na Tabela 47, observa-se que no segundo ensaio de estimativa de viabilidade após a ozonização, uma média de 95,3\% dos cistos de Giardia spp. estavam corados, e para os oocistos, $100 \%$ dos organismos estavam corados, sendo que no último poço não foi detectado nenhum organismo. Quando comparados com o ensaio anterior (Item 5.7.1.1) nota-se que a porcentagem de (oo) cistos não corados foi inferior, neste ensaio em que se utilizou 5 min de tempo de contato. Os resultados serão discutidos no Item 5.7.4.

\subsubsection{Etapa 2 - Ensaios de Desinfecção com o Protocolo de FCCa com IMS}

Os procedimentos de análise adotados no Item 5.7.1, foram repetidos para a etapa 2. Os resultados obtidos a partir da contagem dos (oo) cistos, a fim de conhecer o número de protozoários a serem inoculados na amostra de água filtrada (Tabela 48) e, também, para estimar a viabilidade dos organismos alvos (Tabela 49) estão apresentados a seguir. 
Tabela 48: Determinação do valor e concentração do inóculo a ser utilizado para os $3 \mathrm{~L}$ de água filtrada para o ensaio de ozonização para as suspensões de Giardia spp. e Cryptosporidium parvum para a segunda etapa.

\begin{tabular}{|c|c|c|c|c|c|c|c|}
\hline Suspensão & $\begin{array}{l}\text { Poço da } \\
\text { lâmina }\end{array}$ & $\begin{array}{l}\text { Alíquota } \\
(\mu \mathrm{L})\end{array}$ & $\begin{array}{c}\text { Contagem } \\
\text { de (oo) } \\
\text { cistos }\end{array}$ & $\begin{array}{l}\text { Média de } \\
\text { (oo) cistos } \\
\pm \text { DP ou } \pm \\
\text { CV }(\%)\end{array}$ & $\begin{array}{c}\text { Volume do } \\
\text { inóculo } \\
\text { para os 3L } \\
\text { de amostra } \\
\quad(\mu \mathrm{L})\end{array}$ & $\begin{array}{c}\text { Inóculo para } \\
\text { os } 3 \mathrm{~L} \mathrm{de} \\
\text { amostra } \\
\left.\text { [(oo)cistos.L } \text { L }^{-1}\right]\end{array}$ & $\begin{array}{l}\text { Total } \\
\text { de } \\
\text { (oo) } \\
\text { cistos }\end{array}$ \\
\hline Giardia spp. & $\begin{array}{l}1 \\
2 \\
3\end{array}$ & 5 & $\begin{array}{l}731 \\
626 \\
766\end{array}$ & $\begin{array}{c}708 \pm 59 \\
\text { ou } \pm 8\end{array}$ & 150 & 7080 & 21240 \\
\hline $\begin{array}{c}\text { Cryptosporidium } \\
\text { parvum }\end{array}$ & $\begin{array}{l}1 \\
2 \\
3\end{array}$ & 5 & $\begin{array}{c}108 \\
58 \\
106\end{array}$ & $\begin{array}{l}91 \pm 23 \\
\text { ou } \pm 25\end{array}$ & 150 & 910 & 2730 \\
\hline
\end{tabular}

Para o segundo ensaio de contagem e estimativa de viabilidade, realizado antes do início da etapa 2, observa-se que a suspensão de Giardia spp. obteve valores maiores quando comparados ao primeiro ensaio (Item 5.7.1), pois uma nova suspensão foi utilizada, enquanto que, a suspensão de Cryptosporidium parvum estava no final, portanto, a concentração diminuiu drasticamente, de 11230 oocistos (Item 5.7.1) para 2730 oocistos para os $3 \mathrm{~L}$ de amostra. Como não havia mais suspensões disponíveis, e a mesma, demorava cerca de 2 meses para chegar ao Brasil, optou-se por continuar o uso e para dar continuidade aos ensaios.

Tabela 49: Dados obtidos a partir de ensaios de viabilidade do inóculo da suspensão de Giardia spp. e Cryptosporidium parvum para a segunda etapa.

\begin{tabular}{l|ccc|ccc}
\hline Protozoário & \multicolumn{3}{|c|}{ Giardia spp. } & \multicolumn{3}{c}{ Cryptosporidium parvum } \\
\hline Poço da lâmina & 1 & 2 & 3 & 1 & 2 & 3 \\
\hline (oo) cistos inviáveis (corados) & 649 & 553 & 677 & 100 & 51 & 101 \\
\hline (oo) cistos viáveis (não corados) & 82 & 73 & 89 & 8 & 7 & 5 \\
\hline Inviáveis (\%) & 88,8 & 88,3 & 88,4 & 92,6 & 87,9 & 95,3 \\
\hline Média/DP & \multicolumn{3}{|c|}{$88,5 / 0,2$} & \multicolumn{3}{c}{$91,9 / 3,03$} \\
\hline Viáveis (\%) & 11,22 & 11,66 & 11,62 & 7,41 & 12,07 & 4,72 \\
\hline Média/DP & \multicolumn{3}{c|}{$11,5 / 0,2$} & \multicolumn{3}{c}{$8,1 / 3,03$} \\
\hline
\end{tabular}


Pelos dados observados na Tabela 49, a suspensão de Giardia spp. apresentava 88,5\% de cistos corados e a suspensão de Cryptosporidium parvum possuía 91,9\% dos oocistos corados.

Para a etapa 2, que possui a inclusão do procedimento de IMS, pode ser vantajoso porque a amostra pode ser analisada inteiramente, eliminando assim, o FM (MACIEL; SABOGAL-PAZ, 2016).

Então, visto que o procedimento exige a inclusão de vários passos no protocolo, ao escolher utilizar o IMS, algumas condições devem ser consideradas, como, as características da amostra, o tempo de duração da análise e a sua viabilidade econômica.

\subsubsection{Primeira Parte da Etapa 2}

A caracterização da água de estudo foi realizada e os resultados estão nas Tabelas 50 e 51. A segunda etapa, agora com FCCa e IMS, foi realizada com dosagem definida de ozônio de $5 \mathrm{mg} . \mathrm{L}^{-1}$ e tempo de contato de $1 \mathrm{~min}$, e foi realizado em triplicata e os resultados serão descritos a seguir.

Tabela 50: Caracterização da água filtrada antes da desinfecção e após a ozonização dos 3 ensaios com $5 \mathrm{mgO}_{3} \mathrm{~L}^{-1}$ e tempo de contato de 1 min e com IMS.

\begin{tabular}{cccccc}
\hline Condição & Ensaios & Turbidez (uT) & Cor aparente $(\mathrm{uC})$ & Temperatura $\left({ }^{\circ} \mathrm{C}\right)$ & $\mathrm{pH}$ \\
\hline Antes do ensaio & \multirow{2}{*}{1} & 0,1 & 3,2 & 25 & 7,3 \\
Depois do ensaio & & 0,2 & 3 & 27 & 7,37 \\
\hline Antes do ensaio & \multirow{2}{*}{2} & 0,1 & 1,8 & 23 & 7,24 \\
Depois do ensaio & & 0,1 & 0 & 25 & 7,38 \\
\hline Antes do ensaio & \multirow{2}{*}{3} & 0,1 & 2,4 & 25 & 7,05 \\
Depois do ensaio & & 0,1 & 0 & 28 & 7,3 \\
\hline
\end{tabular}

$\mathrm{Na}$ Tabela 50, observando os dados de turbidez e cor aparente, nota-se que o mesmo fato apontado no item 5.7.1, repete-se. A temperatura manteve-se entre 23 a $28^{\circ} \mathrm{C}$ nesta etapa.

As eficiências médias na transferência de massa de ozônio, a concentração média de ozônio no off-gas, no ozônio residual dissolvido e no ozônio consumido são apresentados na Tabela 51. 
Tabela 51: Concentrações de ozônio aplicado, ozônio do off-gas, ozônio residual dissolvido, ozônio consumido e eficiências na transferência de massa de ozônio para as dosagens de $5 \mathrm{mgO}_{3} \mathrm{~L}^{-1}$ e tempo de contato de $1 \mathrm{~min}$ com IMS.

\begin{tabular}{ccccccc}
\hline Ensaios & $\begin{array}{c}\text { Ozônio } \\
\text { aplicado } \\
\left(\mathrm{mgO}_{3} \mathrm{~L}^{-1}\right)\end{array}$ & $\begin{array}{c}\text { Tempo } \\
\text { contato } \\
(\mathrm{min})\end{array}$ & $\begin{array}{c}\text { Ozônio do } \\
\text { off-gas } \\
\left(\mathrm{mgO}_{3} \mathrm{~L}^{-1}\right)\end{array}$ & $\begin{array}{c}\text { Ozônio } \\
\text { residual } \\
\text { dissolvido } \\
\left(\mathrm{mgO}_{3} \mathrm{~L}^{-1}\right)\end{array}$ & $\begin{array}{c}\text { Ozônio } \\
\text { consumido } \\
\left(\mathrm{mgO}_{3} \mathrm{~L}^{-1}\right)\end{array}$ & $\begin{array}{c}\text { Ozônio } \\
\text { transferido } \\
(\%)\end{array}$ \\
\hline 1 & 5 & 1 & 2,97 & 0,01 & 2,02 & 40,4 \\
2 & 5 & 1 & 0,18 & 0,16 & 4,66 & 93,2 \\
3 & 5 & 1 & 0,30 & 0,02 & 4,68 & 93,6 \\
\hline
\end{tabular}

A eficiência na transferência de massa, a partir da média realizada com os ensaios 1,2 e 3, disponíveis na Tabela 51 , obteve valor de $75,7 \%$ para a dosagem de 5 $\mathrm{mgO}_{3} \mathrm{~L}^{-1}$ e tempo de $1 \mathrm{~min}$.

Na Tabela 52, estão apresentados os dados obtidos da desinfecção de Giardia spp. e Cryptosporidium parvum em $\log _{10}$ para a dosagem de $5 \mathrm{mgO}_{3} \mathrm{~L}^{-1}$ e tempo de contato de $1 \mathrm{~min}$.

Tabela 52: Inativação em $\log _{10}$ de Giardia spp. e Cryptosporidium parvum em relação à dosagem de $5 \mathrm{mgO}_{3} \mathrm{~L}^{-1}$, tempo de contato de 1 min e concentração de ozônio consumido.

\begin{tabular}{ccccccc}
\hline & \multicolumn{2}{c}{ Água com inóculo } & \multicolumn{2}{c}{ Amostra ozonizada } & \multicolumn{2}{c}{ Inativação em $\log _{10}$} \\
Ensaio & \multicolumn{2}{c}{\begin{tabular}{c} 
Cryptosporidium \\
\cline { 3 - 6 }
\end{tabular}} & Giardia & Cryptosporidium & Giardia & Cryptosporidium \\
& & parvum & spp. & parvum & spp. & parvum \\
\hline 1 & 21230 & 2720 & 0 & 1666 & - & 0,21 \\
2 & 21230 & 2720 & 113 & 1706 & 2,27 & 0,2 \\
3 & 21230 & 2720 & 306 & 0 & 1,84 & - \\
\hline
\end{tabular}

No ensaio 2, obteve-se 2,27 log de inativação, maior valor encontrado para cistos de Giardia spp. e o ensaio 1 apresentou inativação de 0,21 log de inativação para Cryptosporidium parvum. As menores desinfecções foram nos ensaios 1 e 3, onde não foram encontrados cistos de Giardia e oocistos de Cryptosporidium, respectivamente. 
Os dados obtidos de recuperação de Giardia spp. e Cryptosporidium parvum para a primeira parte da etapa 2 estão apresentados na Tabela 53.

Tabela 53: Dados de recuperação dos métodos empregados de Giardia spp. e Cryptosporidium parvum para a primeira parte da etapa 2, com dosagem de $5 \mathrm{mgO}_{3} \mathrm{~L}^{-1}$, tempo de contato de 1 min e com IMS.

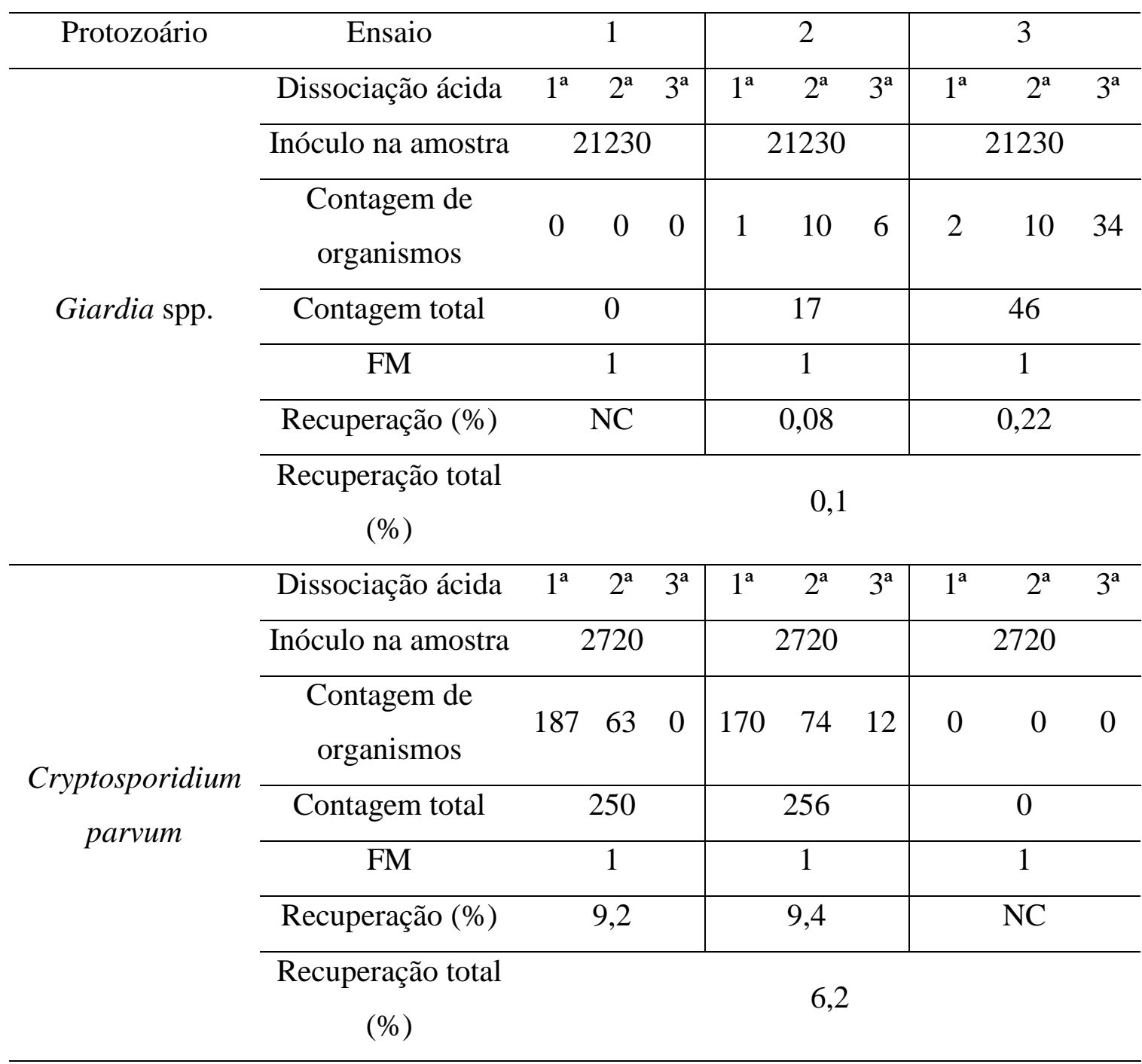

Pelos dados observados na Tabela 53, nota-se que a recuperação para cistos de Giardia spp. ainda continuam baixas e houve um aumento para oocistos, valores similares ao Item 5.7.1.1, onde o tempo de 1 min foi empregado.

Nesta etapa 2, esperava-se maiores recuperações dos parasitos, pois como a amostra toda foi processada durante o procedimento do IMS, as perdas supostamente seriam menores, porém não obteve sucesso. A realização da terceira dissociação ácida 
aumentou o número de protozoários contabilizados no ensaio 2 e 3 para Giardia spp. e no ensaio 2 para Cryptosporidium parvum.

As porcentagens de organismos não corados e corados referentes à primeira parte da etapa 2 estão apresentadas na Tabela 54, baseado nos resultados de recuperação demonstradas na Tabela 53.

Tabela 54: Porcentagem dos organismos não corados e corados referentes à primeira parte da etapa 2.

\begin{tabular}{|c|c|c|c|c|c|c|}
\hline Protozoário & Ensaio & & 1 & & 2 & 3 \\
\hline \multirow{5}{*}{ Giardia spp. } & Poço da lâmina & & 23 & 1 & 2 & 12 \\
\hline & Cistos inviáveis & 0 & $\begin{array}{ll}0 & 0\end{array}$ & 1 & 10 & $\begin{array}{lll}2 & 10 & 34\end{array}$ \\
\hline & Cistos viáveis & 0 & $\begin{array}{ll}0 & 0\end{array}$ & 0 & 0 & 0 \\
\hline & \% cistos inviáveis & & - & & 100 & 100 \\
\hline & \% cistos viáveis & & - & & 0 & 0 \\
\hline \multirow{5}{*}{ Cryptosporidium parvum } & Poço da lâmina & & 23 & & 2 & 2 \\
\hline & Cistos inviáveis & 172 & 600 & 164 & $\begin{array}{ll}73 & 10\end{array}$ & 0 \\
\hline & Cistos viáveis & 15 & 30 & 6 & 1 & 0 \\
\hline & \% cistos inviáveis & \multicolumn{2}{|c|}{93,6} & \multicolumn{2}{|r|}{92,8} & - \\
\hline & \% cistos viáveis & \multicolumn{2}{|c|}{6,4} & \multicolumn{2}{|r|}{7,2} & - \\
\hline
\end{tabular}

Nota: - = ausência de (oo) cistos.

Pelos dados apresentados na Tabela 54, observa-se que no primeiro ensaio de estimativa de viabilidade após a ozonização, uma média de $100 \%$ dos cistos de Giardia spp. estavam corados e no primeiro poço não foi observado nenhum cisto, e para os oocistos, 93,2\% dos organismos estavam corados, sendo que no último poço também não foi detectado nenhum oocisto. Novamente, comparando estes ensaios ao Item 5.7.1.1, onde se utilizou o mesmo tempo de contato de $1 \mathrm{~min}$, verifica-se que há oocistos que não coraram, portanto, este tempo utilizado não foi suficiente para tornar todos os (oo) cistos corados, ou seja, sem a capacidade de contaminar. 


\subsubsection{2. $\quad$ Segunda Parte da Etapa 2}

Os resultados da caracterização da água de estudo estão na Tabela 55 e os dados referentes à segunda etapa, com IMS, foi realizada com dosagem definida de ozônio de $5 \mathrm{mg} . \mathrm{L}^{-1}$ e tempo de contato de $5 \mathrm{~min}$, e foi realizado em triplicata e os resultados serão descritos a seguir.

Tabela 55: Caracterização da água filtrada antes da desinfecção e após a ozonização dos 3 ensaios com $5 \mathrm{mgO}_{3} \mathrm{~L}^{-1}$ e tempo de contato de 5 min e com IMS.

\begin{tabular}{cccccc}
\hline \multicolumn{1}{c}{ Condição } & Ensaios & Turbidez $(\mathrm{uT})$ & Cor aparente $(\mathrm{uC})$ & Temperatura $\left({ }^{\circ} \mathrm{C}\right)$ & $\mathrm{pH}$ \\
\hline Antes do ensaio & \multirow{2}{*}{1} & 0,1 & 0,7 & 25 & 7,07 \\
Depois do ensaio & & 0,1 & 0 & 27 & 7,19 \\
\hline Antes do ensaio & \multirow{2}{*}{2} & 0,1 & 2 & 24 & 7,11 \\
Depois do ensaio & & 0,2 & 0,3 & 25 & 7,13 \\
\hline Antes do ensaio & \multirow{2}{*}{3} & 0,1 & 1,7 & 24 & 7,06 \\
Depois do ensaio & & 0,1 & 0,8 & 25 & 7,28 \\
\hline
\end{tabular}

Na Tabela 55, observando os dados de turbidez e cor aparente, nota-se que o mesmo fato apontado no item 5.7.1.1, repete-se. A temperatura manteve-se entre 24 a $27^{\circ} \mathrm{C}$ nesta última etapa.

As eficiências médias na transferência de massa de ozônio, a concentração média de ozônio no off-gas, no ozônio residual dissolvido e no ozônio consumido são apresentados na Tabela 56.

Tabela 56: Concentrações de ozônio aplicado, ozônio do off-gas, ozônio residual dissolvido, ozônio consumido e eficiências na transferência de massa de ozônio para as dosagens de $5 \mathrm{mgO}_{3} \mathrm{~L}^{-1}$ e tempo de contato de 5 min com IMS.

\begin{tabular}{|c|c|c|c|c|c|c|}
\hline Ensaios & $\begin{array}{c}\text { Ozônio } \\
\text { aplicado } \\
\left(\mathrm{mgO}_{3} \mathrm{~L}^{-1}\right)\end{array}$ & $\begin{array}{c}\text { Tempo } \\
\text { de } \\
\text { contato } \\
\text { (min) }\end{array}$ & $\begin{array}{c}\text { Ozônio do } \\
\text { off-gas } \\
\left(\mathrm{mgO}_{3} \mathrm{~L}^{-1}\right)\end{array}$ & $\begin{array}{c}\text { Ozônio } \\
\text { residual } \\
\text { dissolvido } \\
\left(\mathrm{mgO}_{3} \mathrm{~L}^{-1}\right)\end{array}$ & $\begin{array}{c}\text { Ozônio } \\
\text { consumido } \\
\left(\mathrm{mgO}_{3} \mathrm{~L}^{-1}\right)\end{array}$ & $\begin{array}{c}\text { Ozônio } \\
\text { transferido } \\
(\%)\end{array}$ \\
\hline 1 & 5 & 5 & 0,56 & 0,31 & 4,13 & 82,6 \\
\hline 2 & 5 & 5 & 0,90 & $-0,01^{(1)}$ & 4,11 & 82,2 \\
\hline
\end{tabular}


Nota: ${ }^{(1)}=$ valor abaixo da faixa de medição.

A eficiência na transferência de massa, a partir da média realizada com os ensaios 1,2 e 3 (Tabela 56), obteve o valor de $84 \%$ para a dosagem de $5 \mathrm{mgO}_{3} \mathrm{~L}^{-1}$ e tempo de $5 \mathrm{~min}$.

Na Tabela 57, estão apresentados os dados obtidos da desinfecção de Giardia spp. e Cryptosporidium parvum em $\log _{10}$ para a dosagem de $5 \mathrm{mgO}_{3} \mathrm{~L}^{-1}$ e tempo de contato de $5 \mathrm{~min}$.

Tabela 57: Inativação em $\log _{10}$ de Giardia spp. e Cryptosporidium parvum em relação à dosagem de $5 \mathrm{mgO}_{3} \mathrm{~L}^{-1}$, tempo de contato de 5 min e concentração de ozônio consumido.

\begin{tabular}{ccccccc}
\hline \multirow{2}{*}{ Ensaio } & \multicolumn{2}{c}{ Água com inóculo } & \multicolumn{2}{c}{ Amostra ozonizada } & \multicolumn{2}{c}{ Inativação em $\log _{10}$} \\
& Giardia spp. & $\begin{array}{c}\text { Cryptosporidium } \\
\text { parvum }\end{array}$ & Giardia & Cryptosporidium & Giardia & Cryptosporidium \\
& & spp. & parvum & spp. & parvum \\
\hline 1 & 21230 & 2720 & 26 & 0 & 2,9 & - \\
2 & 21230 & 2720 & 60 & 533 & 2,54 & 0,7 \\
3 & 21230 & 2720 & 0 & 13 & - & 2,33 \\
\hline
\end{tabular}

No ensaio 1, obteve-se 2,9 log de inativação, maior valor encontrado para cistos de Giardia spp. e o ensaio 3 apresentou inativação de 2,33 log de inativação para Cryptosporidium parvum. As menores desinfecções foram no ensaio 3 e 1, onde não foram encontrados cistos e oocistos, respectivamente.

Os dados obtidos de recuperação de Giardia spp. e Cryptosporidium parvum para a segunda da etapa 2 estão apresentados na Tabela 58. 
Tabela 58: Dados de recuperação dos métodos empregados de Giardia spp. e Cryptosporidium parvum para a segunda parte da etapa 2, com dosagem de $5 \mathrm{mgO}_{3} \mathrm{~L}^{-1}$, tempo de contato de 5 min e com IMS.

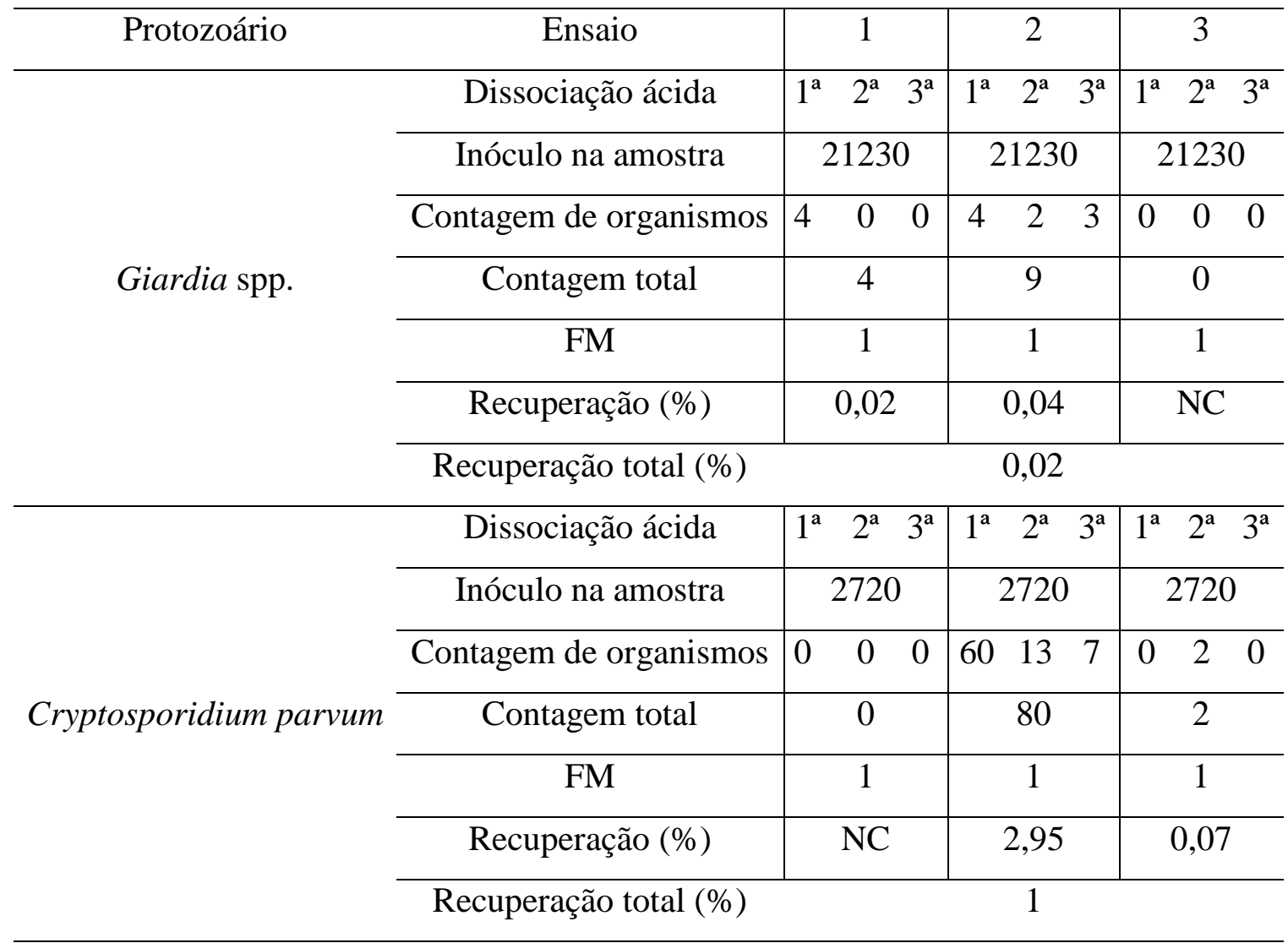

Nota: NC = não calculado.

Pelos dados apresentados na Tabela 58, a mesma condição se repete quando comparado ao Item 5.7.1.2, nota-se baixíssimas recuperações para ambos os parasitos, apesar do uso da IMS.

As porcentagens de organismos não corados e corados referentes à segunda parte da etapa 2, estão apresentados na Tabela 59, baseado nos resultados de recuperação demonstrados na Tabela 58. 
Tabela 59: Porcentagem dos organismos não corados e corados referentes à segunda parte da etapa 2.

\begin{tabular}{|c|c|c|c|c|c|}
\hline Protozoário & Ensaio & & 1 & 2 & 3 \\
\hline \multirow{5}{*}{ Giardia spp. } & Poço da lâmina & 1 & 23 & 123 & 23 \\
\hline & Cistos inviáveis & 4 & $\begin{array}{ll}0 & 0\end{array}$ & 23 & $\begin{array}{ll}0 & 0\end{array}$ \\
\hline & Cistos viáveis & 0 & $\begin{array}{ll}0 & 0\end{array}$ & $\begin{array}{ll}0 & 0\end{array}$ & 00 \\
\hline & \% cistos inviáveis & & 100 & 100 & - \\
\hline & \% cistos viáveis & & 0 & 0 & 0 \\
\hline \multirow{5}{*}{ Cryptosporidium parvum } & Poço da lâmina & 1 & 2 & 23 & 23 \\
\hline & Cistos inviáveis & 0 & 0 & $\begin{array}{lll}59 & 13 & 7\end{array}$ & 20 \\
\hline & Cistos viáveis & & 0 & $\begin{array}{ll}0 & 0\end{array}$ & 0 \\
\hline & \% cistos inviáveis & & - & 99,4 & 100 \\
\hline & \% cistos viáveis & & - & 0,6 & 0 \\
\hline
\end{tabular}

Nota: - = ausência de (oo) cistos.

Pelos dados apresentados na Tabela 59, observa-se que o último ensaio de estimativa de viabilidade após a ozonização, uma média de 100\% dos cistos de Giardia spp. estavam corados e no último poço não foi observado nenhum cisto, e para os oocistos, 99,7\% dos organismos penetraram o corante, sendo que no primeiro poço também não foi detectado nenhum oocisto. Comparando estes ensaios com o Item 5.7.1.2, observa-se que, o tempo de contato de $5 \mathrm{~min}$ apresentou maior eficiência na inativação dos (oo) cistos, relatando $14,3 \%$ de cistos não corados (Tabela 47) e uma pequena porcentagem de $0,3 \%$ de oocistos não corados no presente ensaio.

\subsubsection{Eficiências na transferência de massa, Temperatura e pH}

Pelos dados apresentados nas Tabelas 39, 44, 51 e 56, pode-se observar que, como a dosagem de $5 \mathrm{mgO}_{3} \mathrm{~L}^{-1}$ foi fixada e o que variou foi o tempo de contato, para o valor de $1 \mathrm{~min}$, as eficiências na transferência de massa para a primeira etapa (sem IMS) foram de 59,6\% e para a segunda (com IMS), 75,7\%. Para o tempo de $5 \mathrm{~min}$, na primeira etapa (sem IMS), a eficiência foi de 58,3\% e na segunda etapa (com IMS) foi de $84 \%$. Lembrando que, estes dados correspondem à eficiência média obtida a partir da triplicata realizada. 
Miranda (2014) em ensaios de ozonização com efluente proveniente de alagados construídos, obteve para a dose de $5 \mathrm{mgO}_{3} \mathrm{~L}^{-1}$ e tempos de contato de 5 e 10 min, eficiência na transferência de massa de $94,4 \%$, valor maior ao encontrado nesta pesquisa, utilizando a mesma dose e tempo de contato de 5 min. Silva et al., (2010) obtiveram uma eficiência na transferência de massa de $76 \%$ para a dose de $5 \mathrm{mgO}_{3} \mathrm{~L}^{-1} \mathrm{e}$ tempo de contato de 5 min, na desinfecção de efluentes de esgoto sanitário com ozônio. Neste caso, os pesquisadores encontraram valor maior ao desta pesquisa, quando comparado com a primeira etapa e menor, em relação à segunda etapa.

A menor eficiência, encontrada tanto na primeira parte da etapa 1, utilizando 1 min, $(59,6 \%)$ quanto na segunda parte da mesma etapa $(58,3 \%)$, pode ser devido às condições empregadas, como a temperatura, que pode afetar a solubilidade do ozônio, ou seja, o aumento da temperatura da água reduz a solubilidade do ozônio, que influencia a taxa de reação.

Miranda (2014) trabalhou com temperatura ambiente de 17 a $24^{\circ} \mathrm{C}$, e Silva et al., (2010) utilizaram em sua pesquisa, temperatura ambiente de 20 a $30^{\circ} \mathrm{C}$.

Nesta pesquisa, as temperaturas referentes ao início do ensaio permaneceram entre 20 e $25^{\circ} \mathrm{C}$, o que, a princípio, não foi um fator que influenciou na desinfecção com o ozônio, pois na segunda etapa dos ensaios, descrito no Item 5.7.2, a média das temperaturas foi de $24^{\circ} \mathrm{C}$ e também, foram as maiores eficiências de transferência $(75,7$ e $84 \%$ para primeira e segunda parte, respectivamente).

Silveira (2004) e Lapolli et al., (2010) reportaram que o aumento da temperatura não altera consideravelmente a taxa de desinfecção do ozônio. Wickramanayake, Rubin e Sproul (1984) dizem que a resistência dos cistos de Giardia lamblia parece aumentar quando a temperatura cai de 25 para $5^{\circ} \mathrm{C}$ em $\mathrm{pH}$ neutro $(\mathrm{pH}$ 7). E, quando comparado com a cloração para a desinfecção de cistos de Giardia lamblia, o ozônio é menos afetado pela temperatura.

A eficiência de transferência de massa de ozônio da fase gasosa para a líquida é controlada por fatores tais como, a concentração do ozônio na fase gasosa, a vazão do gás, as condições de mistura, o tamanho, a concentração e a velocidade bas bolhas, a geometria da câmara de contato e as características físicas e químicas da água ou esgoto (SOARES, 2007).

Outro fator que, a priori, não influenciou na desinfecção com o ozônio foi o pH. Os valores de pH para esta pesquisa ficaram na faixa de 7 a 7,4. Lapolli et al., (2010) afirmam que, a maioria dos dados disponíveis na literatura indicam que a eficiência da 
desinfecção por ozônio é pouco afetada na faixa de $\mathrm{pH}$ dos efluentes domésticos (entre 6 e 8) e dizem também que, o efeito do $\mathrm{pH}$ pode estar relacionado ao tipo de microrganismo-alvo, e não a uma influência relacionada à especiação do ozônio em água, a qual é influenciada pelo pH. Soares (2007) também não notou variações significativas do $\mathrm{pH}$ e da temperatura que interferissem nos resultados da ozonização.

Em todos os ensaios, observou-se a redução de cor aparente, outra vantagem de utilizar o ozônio como desinfetante. Benetti, De Luca e Cybis (2009) citam a remoção de cor como uma das principais aplicações de ozônio no tratamento de água.

\subsubsection{Inativação, recuperação e perdas dos parasitos}

Para os ensaios realizados na Etapa 1, que se utilizou $5 \mathrm{mgO}_{3} \mathrm{~L}^{-1}$ e tempo de contato de 1 min sem a realização da etapa de IMS, as maiores inativações atingidas foram de 2,52 e 2,22 log de inativação para cistos de Giardia spp. e oocistos de Cryptosporidium parvum, respectivamente. Quando se comparou com o tempo de contato de $5 \mathrm{~min}$, as maiores inativações foram de 2,52 e 2,92 log de inativação de cistos de Giardia spp. e oocistos de Cryptosporidium parvum, respectivamente. Nota-se que para o tempo de 5 min, a inativação foi ligeiramente maior para os oocistos e manteve-se igual para Giardia spp., nos dois tempos de contato utilizado.

Passos et al., (2014) analisaram a ozonização para inativar cistos de Giardia spp. em águas residuais e utilizaram o método de concentração de FCCa, sem a etapa de IMS e relataram $75 \%$ de inativação, utilizando dosagem de $11 \mathrm{mgO}_{3} \mathrm{~L}^{-1}$ e tempo de contato de $10 \mathrm{~min}$ (CT de $110 \mathrm{mg} \cdot \mathrm{min} . \mathrm{L}^{-1}$ ). Utilizando a dosagem de $21 \mathrm{mgO}_{3} \mathrm{~L}^{-1}$ e tempo de contato de $15 \mathrm{~min}$ (CT de $110 \mathrm{mg} \cdot \mathrm{min}_{\mathrm{L}} \mathrm{L}^{-1}$ ) foi suficiente para eliminar $100 \%$ de cistos de Giardia spp.

Medeiros (2010) nos ensaios onde avaliou a ozonização de efluentes, utilizou o método de concentração por centrifugação, sem a etapa de IMS. Este método obteve boa recuperação para Giardia spp. $(57,4 \% \pm 22,4)$ mas baixa para Cryptosporidium spp. $(3,5 \% \pm 1,1)$. Os resultados para viabilidade foram prejudicados devido ao pequeno número de (oo) cistos encontrados e em alguns casos à ausência de (oo) cistos na lâmina. A inativação máxima de Giardia spp. foi de 0,06 log e para Cryptosporidium spp, que foi detectado no efluente ozonizado em apenas um ensaio, foi de $0,18 \mathrm{log}$.

Na Etapa 2, com a inclusão da etapa de IMS, utilizando a mesma dosagem e tempo de contato de $1 \mathrm{~min}$, obteve-se 2,27 e 0,21 log de inativação para cistos e 
oocistos, respectivamente. Comparando-se com o tempo de contato de $5 \mathrm{~min}$, as maiores desinfecções foram de 2,9 e 2,3 log de inativação para cistos e oocistos, respectivamente.

Para verificar se houve diferenças significativas entre os tempos de contato, ou seja, se os valores adotados de tempo são estatisticamente diferentes ou não, foram realizados testes de hipóteses (Teste-t: duas amostras em par para médias) e a Tabela 60 apresenta as hipóteses utilizadas para aplicação do teste-t, a partir dos dados de recuperação da Etapa 1 e 2, para ambos os protozoários.

Tabela 60: Considerações sobre os testes de hipóteses adotados a fim de comparar os tempos de contato de 1 e 5 min, nas Etapas 1 e 2.

Hipótese nula $\left(\mathrm{H}_{0}\right)$ : os tempos de contato adotados não são estatisticamente diferentes, ou seja, os tempos possuem a mesma eficiência.

Hipótese alternativa $\left(\mathrm{H}_{\mathrm{a}}\right)$ : os tempos de contato adotados são estatisticamente diferentes, ou seja, um tempo é melhor que o outro.

n: número de amostras do ensaio.

g: grau de liberdade (n-1).

Intervalo de confiança: $95 \%$

$\alpha$ : nível de confiança do teste $(1-$ intervalo de confiança $=5 \%)$.

Se o valor t estiver na região crítica, aceita-se $\mathrm{H}_{0}$.

Se o valor t não estiver na região crítica, aceita-se a $\mathrm{H}_{\mathrm{a}}$.

Para aplicar o teste-t, utilizou-se os valores de recuperações obtidos nas Etapas 1 e 2, e comparou-se as recuperações encontradas no tempo de 1 min e com o tempo de 5 min, na primeira etapa (sem IMS) e para a segunda etapa (com IMS), a mesma comparação foi efetuada, para ambos os protozoários e os dados estão apresentados na Tabela 61. 
Tabela 61: Dados utilizados para aplicação do teste-t e valores obtidos.

\begin{tabular}{|c|c|c|c|c|}
\hline Etapa & Métodos & Tempo de contato & Protozoários & Valor-p \\
\hline \multirow{2}{*}{1} & \multirow{2}{*}{ Sem IMS } & \multirow{2}{*}{$1-5 \min$} & Giardia spp. & 0,1859 \\
\hline & & & Cryptosporidium parvum & 0,3845 \\
\hline \multirow{2}{*}{2} & \multirow{2}{*}{ Com IMS } & \multirow{2}{*}{$1-5 \min$} & Giardia spp. & 0,3827 \\
\hline & & & Cryptosporidium parvum & 0,1994 \\
\hline
\end{tabular}

Observando os dados mostrados na Tabela 61, as Etapas 1 e 2, apresentaram valores de $\mathrm{p}$ dentro da região crítica $(\mathrm{p}>0,05)$ o que indica, que a hipótese nula deve ser aceita, e conclui-se que os tempos de contato adotados não são estatisticamente diferentes, ou seja, os tempos possuem a mesma eficiência.

Então, resumindo os dados obtidos nas etapas analisadas, não houve diferenças significativas entre os tempos de contato de 1 e $5 \mathrm{~min}$, os tempos adotados se comportaram da mesma forma na inativação de Giardia spp. e Cryptosporidium parvum.

Wickramanayake, Rubin e Sproul (1984) em seu estudo de desinfecção com ozônio, realizaram um inóculo de cistos de Giardia lamblia em água destilada, utilizando temperatura de $5^{\circ} \mathrm{C}$ e $\mathrm{pH} 7$, e concentraram a amostra utilizando centrifugação. $\mathrm{O}$ valor de $\mathrm{Ct}$ (concentração x tempo) utilizado foi de $0,53 \mathrm{mg} \cdot \mathrm{min} . \mathrm{L}^{-1} \mathrm{e}$ obtiveram 99\% de remoção, atingindo $2 \log$ de inativação para cistos de Giardia, fazendo uso da técnica de excistação para análise da viabilidade dos cistos.

Finch et al., (1993) para obter o mesmo log de inativação e eficiência para cistos de Giardia lamblia, previamente inoculados em amostra de água e concentrados por centrifugação, precisaram de valor de $\mathrm{Ct}$ de $0,65 \mathrm{mg} \cdot \mathrm{min} \cdot \mathrm{L}^{-1}$ e o estudo foi realizado com $22^{\circ} \mathrm{C}$ de temperatura e com a técnica de infectividade in vivo.

Para verificar se houve diferenças significativas entre os métodos empregados, ou seja, se os métodos de FCCa sem a etapa de purificação e com a inclusão desta fase são estatisticamente diferentes ou não, foram realizados testes de hipóteses (Teste-t: duas amostras em par para médias) e as hipóteses utilizadas para aplicação do teste-t, a partir dos dados de recuperação da Etapa 1 e 2, para ambos os protozoários estão apresentadas na Tabela 62. 
Tabela 62: Considerações sobre os testes de hipóteses adotados a fim de comparar os métodos de FCCa sem e com IMS, para os tempos de 1 e 5 min, nas Etapas 1 e 2.

Hipótese nula $\left(\mathrm{H}_{0}\right)$ : os métodos adotados não são estatisticamente diferentes, ou seja, os métodos possuem a mesma eficiência.

Hipótese alternativa $\left(\mathrm{H}_{\mathrm{a}}\right)$ : os métodos adotados são estatisticamente diferentes, ou seja, um método é mais eficiente que o outro.

n: número de amostras do ensaio.

g: grau de liberdade (n-1)

Intervalo de confiança: $95 \%$

$\alpha$ : nível de confiança do teste $(1-$ intervalo de confiança $=5 \%)$.

Se o valor t estiver na região crítica, aceita-se $\mathrm{H}_{0}$.

Se o valor $t$ não estiver na região crítica, aceita-se a $\mathrm{H}_{\mathrm{a}}$.

Tabela 63: Dados utilizados para aplicação do teste-t e valores obtidos.

\begin{tabular}{cccc}
\hline Protozoários & Tempo (min) & Método & Valor-p \\
\hline Giardia spp. & 1 & Sem e com IMS & 0,0692 \\
Cryptosporidium parvum & & & 0,8354 \\
\hline Giardia spp. & 5 & Sem e com IMS & 0,0074 \\
Cryptosporidium parvum & & & 0,4335 \\
\hline
\end{tabular}

Conforme os resultados obtidos, apenas o ensaio utilizando Giardia spp. e tempo de 5 min apresentou valor-p menor que 0,05 , ou seja, rejeita-se $\mathrm{H}_{0}$ e assume-se a hipótese $\mathrm{H}_{\mathrm{a}}$, que indica que houve diferença significativa entre os métodos testados, e o método de FCCa sem IMS apresentou melhores resultados. Em relação aos demais, não houve grandes variações entre as Etapa 1 e 2, quanto ao uso ou não do IMS, as recuperações foram baixas para ambos parasitos e ambos os métodos.

A baixa recuperação dos (oo) cistos pode ter ocorrido por várias razões, dentre elas, a grande manipulação das amostras provenientes das inúmeras etapas e procedimentos relacionados ao método, tais como, transferência de volumes entre tubos, 
retirada de volumes sobrenadantes, entre outros, podem também levar a perda de organismos (SANTOS et al., 2011; ROBERTSON et al., 2000; SANTOS, 2015).

Outra condição que pode ter contribuído para as perdas de (oo) cistos, e com isso, resultar em baixa recuperação dos parasitos, foi em relação à coluna de ozonização construída em acrílico, onde não era possível adicionar Tween 80 para enxaguar a coluna e assim evitar a aderência dos protozoários, pois resultava em formação de espuma. Medeiros (2010) em seu estudo de ozonização também relatou pequenos números de (oo) cistos encontrados, e citou que isto pode ter ocorrido devido ao arraste dos protozoários para a superfície do líquido dentro da coluna de ozonização com a formação de espuma.

Um fator muito interessante e relevante em relação à ozonização, observando a Figura 46, nota-se que o cisto de Giardia spp. visualizado após a desinfecção apresentase deformado, com ondulações na estrutura, fator que pode ser explicado pela dosagem (5 $\left.\mathrm{mgO}_{3} \cdot \mathrm{L}^{-1}\right)$ e tempo de contato $(5 \mathrm{~min}$ ) aplicados que ao atingirem o parasito, enfraqueceram o organismo e romperam a estrutura da membrana.
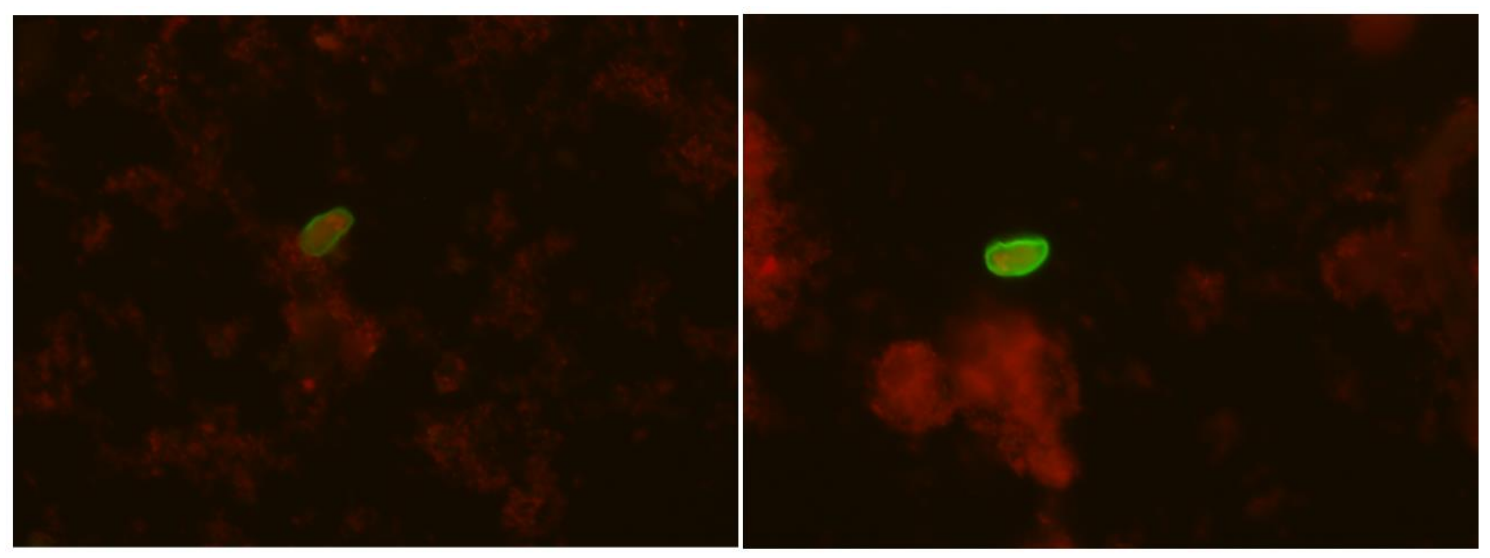

Figura 46: Cistos de Giardia spp. com deformação após a desinfecção com o ozônio (Aumento de $400 \mathrm{x}$ ).

Hsu e Yeh (2003) em seu estudo com amostras de água, utilizaram dosagens de ozônio de pré e pós-ozonização de 0,3 - 3,5 e 1,6 - 4,8 mg. $\mathrm{L}^{-1}$, respectivamente e os resultados mostraram que a pré-ozonização pode danificar/destruir eficazmente a estrutura de (oo) cistos, especialmente cistos de Giardia.

Widmer et al., (2002) avaliaram alterações estruturais e bioquímicas em cistos de Giardia lamblia expostos ao ozônio. Os cistos foram expostos a uma concentração de ozônio inicial de 1,5 mg.L. $\mathrm{L}^{-1}$ para $0,30,60,120 \mathrm{~s}$. Este tratamento resultou numa 
redução dependente da dose na concentração de cistos, a perda de infecciosidade, e profundas modificações estruturais na parede do cisto. A exposição durante $60 \mathrm{~s}$ ou mais, resultou em uma degradação extensa de proteína e no desaparecimento da parede do cisto.

Na avaliação da estimativa da viabilidade dos parasitos recuperados no método, houve a predominância de (oo) cistos que incluíram o corante, ou seja, que foram considerados inativos, tanto nos ensaios utilizando tempo de contato de 1 min quanto de 5 min. Nesta pesquisa, para a primeira etapa com tempo de 1 min sem IMS, 100\% dos cistos de Giardia spp. eram inviáveis, e para os oocistos, uma média de 77,5\% (DP 13,7) dos organismos eram inviáveis. Para o mesmo valor de tempo e agora com FCCa e IMS, uma média de $100 \%$ dos cistos de Giardia spp. eram inviáveis e para os oocistos, 93,2\% (DP 0,4) dos organismos eram inviáveis.

Para o tempo de 5 min sem IMS, obteve-se, uma média de 95,3\% (DP 6,7) dos cistos de Giardia spp. inviáveis e para os oocistos, $100 \%$ dos organismos eram inviáveis. Utilizando o mesmo tempo e agora, com FCCa e IMS, uma média de 100\% de cistos de Giardia spp. inviáveis e para oocistos de Cryptosporidium parvum, foram detectados 99,7\% (DP 0,3) oocistos inviáveis.

Essa predominância de resultados com incorporação do corante (IP+) também foi observado por Quintero-Betancourt et al., (2003), que utilizaram amostras de água que foram coletadas de quatro instalações de reuso e usaram cápsulas de filtros Envirochek, e relataram que os oocistos IP+ foram os mais detectados e contados, responsável por mais de $80 \%$ dos oocistos presentes em todas as amostras analisadas de efluentes recuperados. Os cistos de Giardia spp. foram predominantemente detectados como IP+, obtendo $100 \%$ de cistos inativos ou não viável.

No estudo de Olvera e Ilangovan (2008), referente à desinfecção de oocistos de Cryptosporidium parvum em água utilizando tratamento ultrassônico, os pesquisadores utilizaram o IP para avaliar a viabilidade após o tratamento e relataram que após 2 min de exposição a viabilidade diminuiu de 90 para $87,82 \%$ e após $4 \mathrm{~min}$, o número de oocistos não viáveis aumentou para 94,02\%.

Castro-Hermida et al., (2010) em seu estudo determinaram a concentração média de cistos de Giardia spp. e oocistos de Cryptosporidium spp. em rios de áreas recreacionais, em estações de tratamento de água e estações de tratamento de águas residuais, utilizando sistema de filtros Filta-Max para concentrar a amostra, seguido de 
IMS e uso do IP para determinar a viabilidade e a porcentagem da viabilidade dos (oo) cistos variou entre 90 e $95 \%$, em todas as amostras analisadas.

Para esta pesquisa, a mesma condição foi observada, onde houve baixíssima recuperação de parasitos após a desinfecção e a estimativa da viabilidade, a predominância de (oo) cistos inviáveis após o tratamento.

Nesta pesquisa, a quantidade de protozoários inoculados na água filtrada foi grande ( \pm 30.000 (oo) cistos) e isto ocorreu devido a finalidade da pesquisa, que foi avaliar a eficiência do ozônio e realizar a estimativa de viabilidade dos cistos de Giardia spp e de oocistos de Cryptosporidium parvum após a desinfecção, e para isto, foi necessário inocular elevada quantidade de (oo) cistos, superior ao valor encontrado em água obtida após a filtração, para efetuar a recuperação após o tratamento e ser passível de realizar as análises.

Enfim, mesmo utilizando o ozônio como desinfetante, foram encontrados (oo) cistos após o tratamento, o que indica que, a utilização do ozônio não é garantia de água segura para consumo humano, e que outras dosagens e tempos de contato devem ser avaliados, caso a caso, para assegurar a qualidada da água.

\subsection{Influência da inclusão da terceira dissociação ácida nos ensaios com IMS}

A avaliação da inclusão da terceira dissociação ácida nos ensaios com IMS foi realizada para verificar o possível aumento da recuperação de protozoários no método testado e analisar a influência desta dissociação nos ensaios.

Para iniciar, verificou-se a porcentagem de recuperação dos (oo) cistos encontrados, considerando a quantidade de (oo) cistos visualizados em cada dissociação dividido pelo somatório dos protozoários visualizados nas três dissociações realizadas para cada amostra. A influência de cada dissociação foi calculada para os ensaios da Etapa 2, de FCCa com IMS, para os tempos de contato adotados, 1 e 5 min, para cada protozoário com os dados disponíveis nas Tabelas 53 e 58. As Figuras 47 a 50 apresentam os resultados da inclusão da terceira dissociação ácida quando comparada as demais em porcentagem de recuperação. 


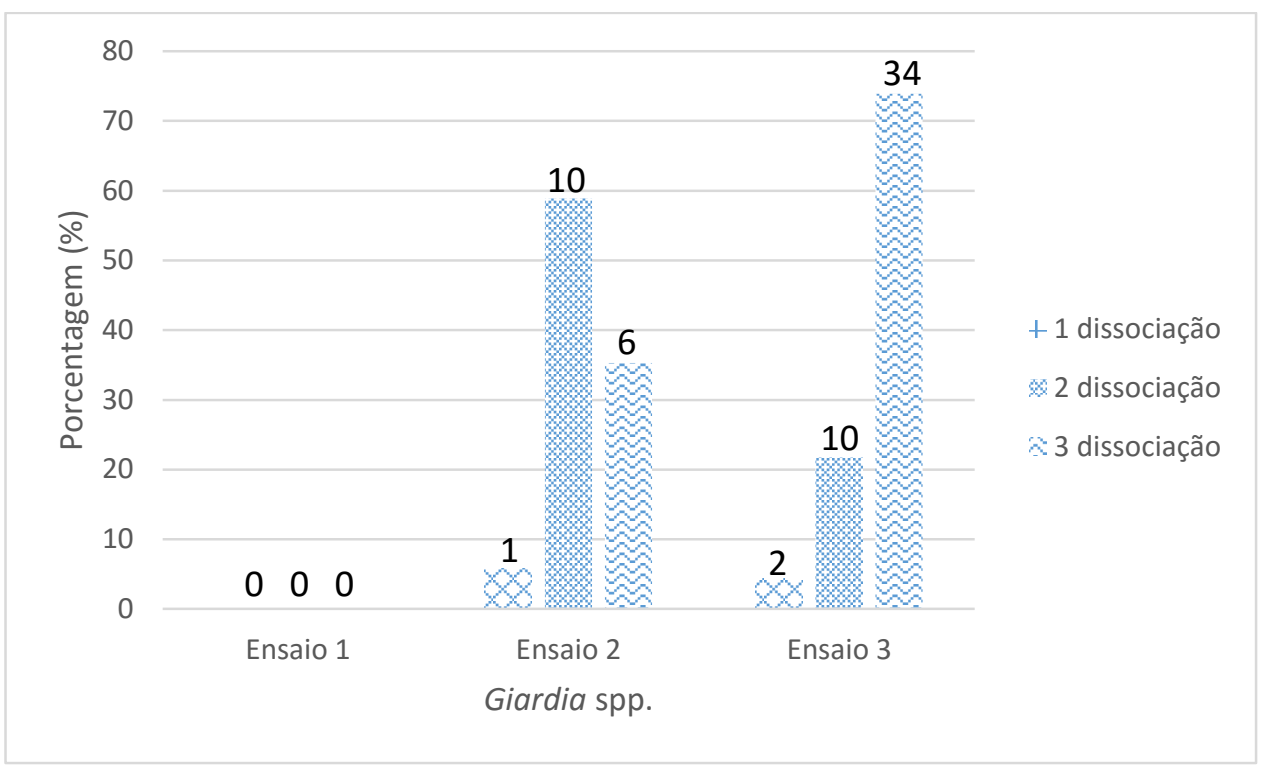

Figura 47: Porcentagem de recuperação de Giardia spp. em cada dissociação para o tempo de 1 min relacionado com o número de parasitos encontrados por dissociação.

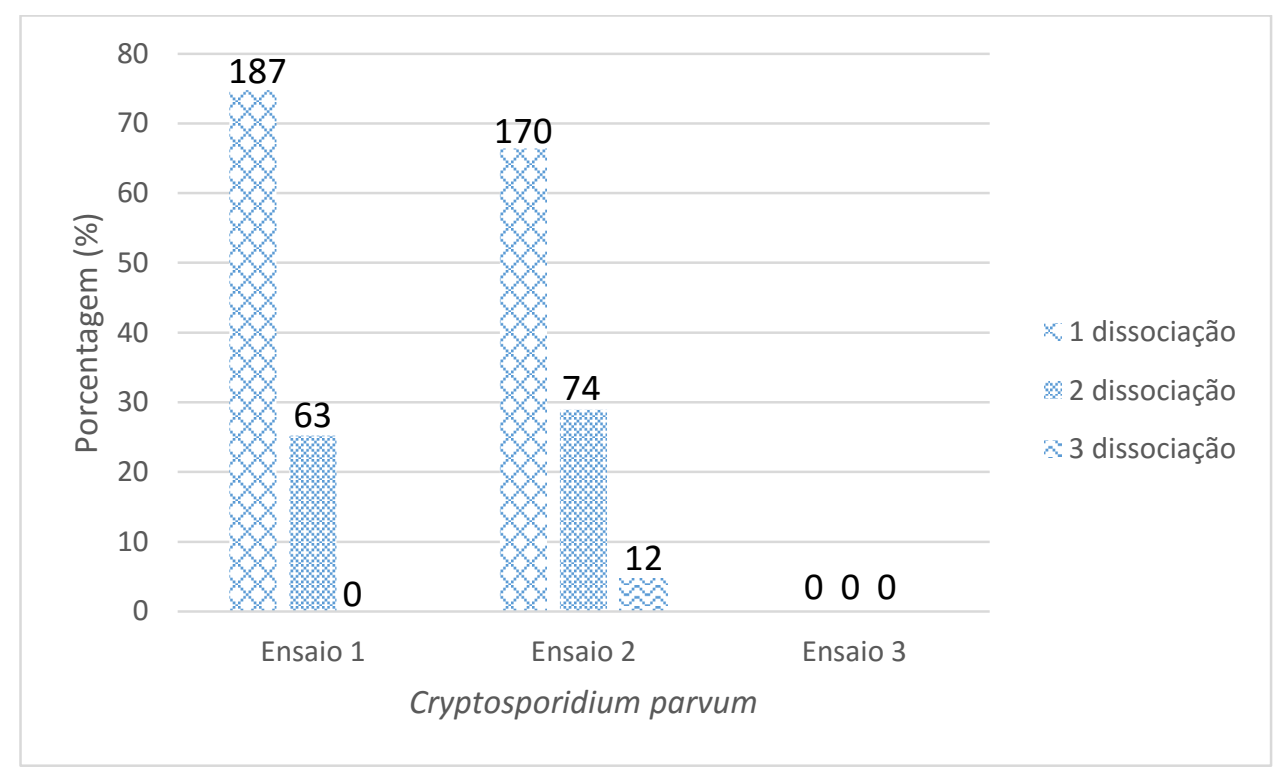

Figura 48: Porcentagem de recuperação de Cryptosporidium parvum para cada dissociação para o tempo de 1 min relacionado com o número de parasitos encontrados por dissociação. 


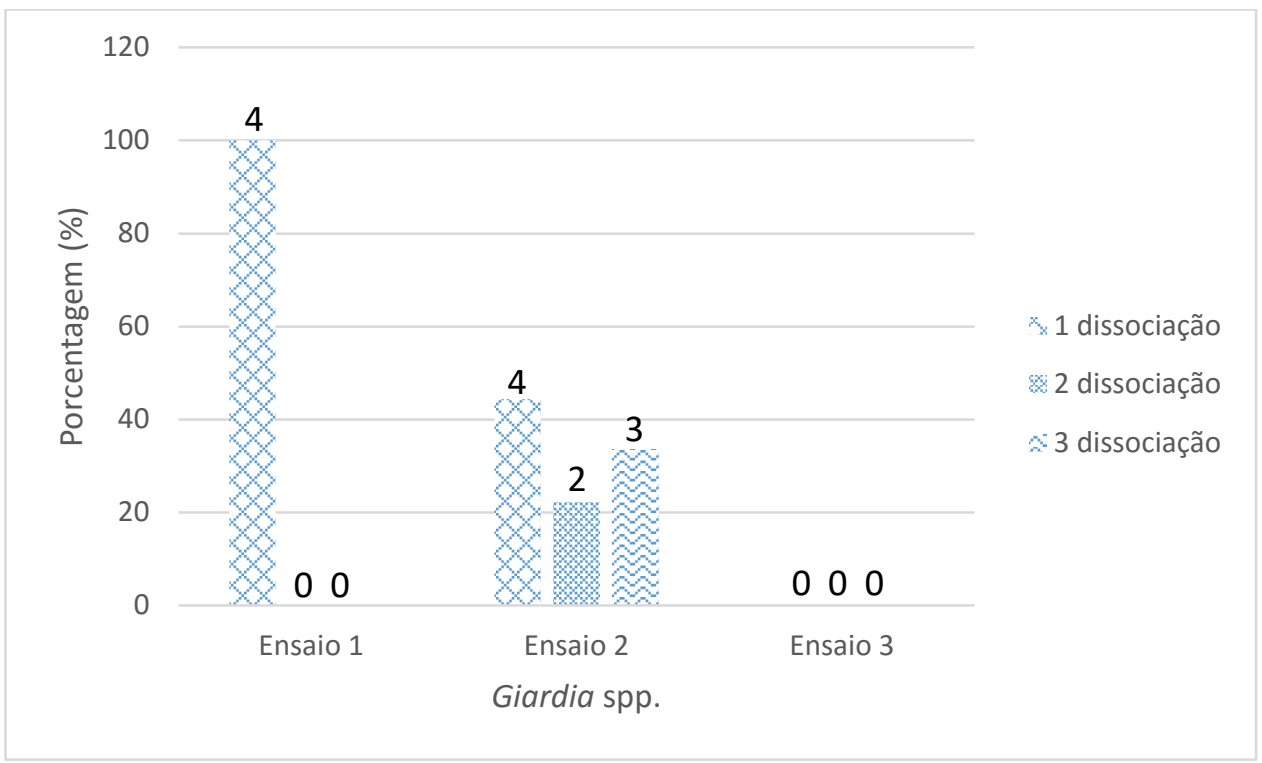

Figura 49: Porcentagem de recuperação de Giardia spp. para cada dissociação para o tempo de 5 min relacionado com o número de parasitos encontrados por dissociação.

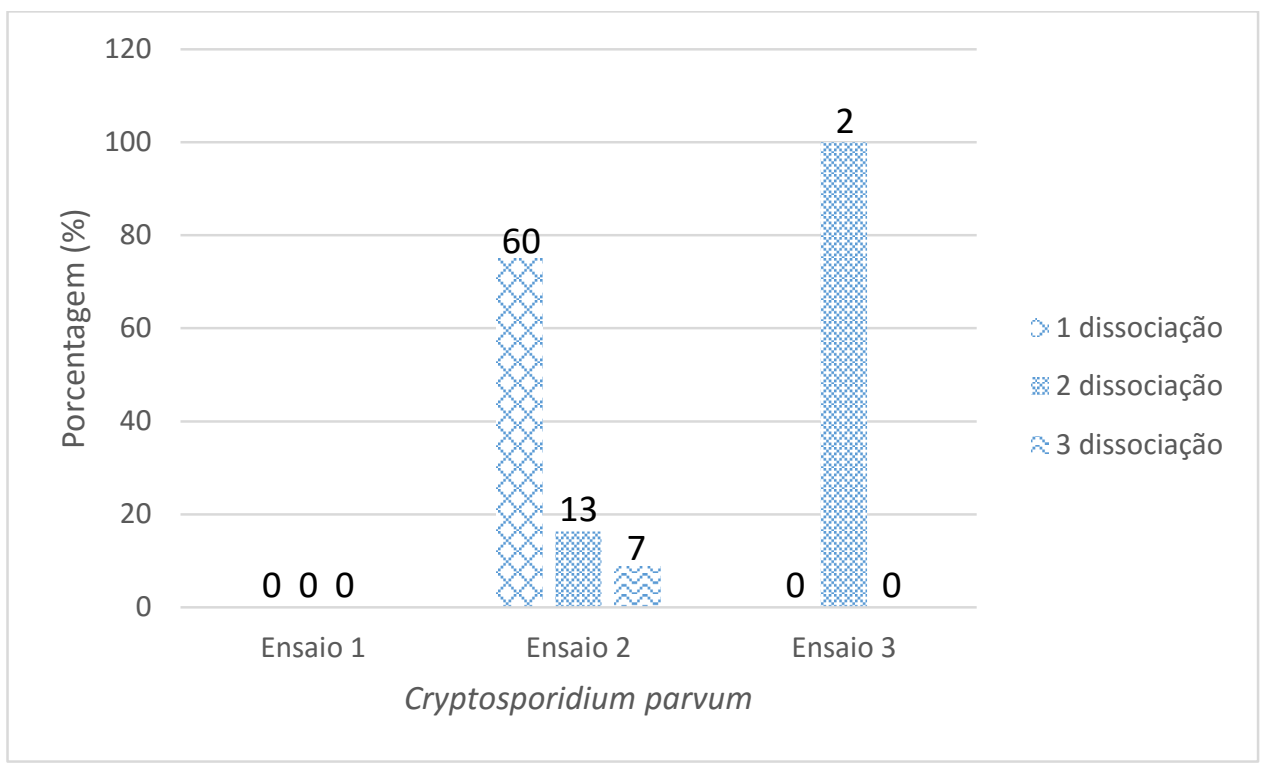

Figura 50: Porcentagem de recuperação de Cryptosporidium parvum para cada dissociação para o tempo de 5 min relacionado com o número de parasitos encontrados por dissociação.

Observa-se que, na Figura 47, a terceira dissociação contribuiu com 35,3\% no ensaio 2 e com 73,9\% no ensaio 3 na recuperação de cistos de Giardia spp. No ensaio 1 não se encontrou nenhum cisto. Para Cryptosporidium parvum, a terceira dissociação contribuiu com somente $4,7 \%$ no ensaio 2 , e para os ensaios 1 e 3 , não se encontrou 
nenhum oocisto (Figura 48). Mesmo com a inclusão da terceira dissociação, as recuperações alcançadas foram extremamente baixas.

Em relação a Figura 49, a terceira dissociação, no ensaio 2 de Giardia spp., obteve recuperação de $33,4 \%$, não sendo encontrados nenhum cisto nos demais. Na Figura 50, o valor foi ainda inferior, e a terceira dissociação contribuiu com apenas 8,7 \% no ensaio 2 e nos ensaios restantes, não houve recuperação. A condição abordada acima, se repete, e mesmo incluindo a terceira dissociação, as recuperações se mantiveram baixas.

Para confirmar se houve diferenças entre os resultados nas recuperações, com duas ou mesmo após a introdução na terceira dissociação ácida, foram realizados testes de hipóteses (teste - t: duas amostras em par para médias), utilizando os dados da Etapa 2, da FCCa com IMS, com os valores obtidos na contagem de organismos, tanto com duas e com três dissociações. As considerações utilizadas nos testes estão apresentadas na Tabela 64.

Tabela 64: Considerações sobre os testes de hipóteses utilizados para comparação entre as recuperações com duas e três dissociações ácidas.

Hipótese nula $\left(\mathrm{H}_{0}\right)$ : o número de protozoários observados com três dissociações ácidas é igual ao número observado com duas dissociações ácidas.

Hipótese alternativa $\left(\mathrm{H}_{\mathrm{a}}\right)$ : o número de protozoários contados com três dissociações

ácidas é maior do que o número contado com duas dissociações ácidas.

n: número de amostras do ensaio.

g: grau de liberdade (n-1).

Intervalo de confiança: $95 \%$

$\alpha$ : nível de confiança do teste $(1-$ intervalo de confiança $=5 \%)$.

Se o valor t estiver na região crítica, aceita-se $\mathrm{H}_{0}$.

Se o valor t não estiver na região crítica, aceita-se a $\mathrm{H}_{\mathrm{a}}$.

Tabela 65: Resultados do teste de hipóteses comparando as recuperações com duas e três dissociações ácidas.

Protozoários

Tempo (min)
Método

Valor-p 


\begin{tabular}{cccc}
\hline Giardia spp. & 1 & $\begin{array}{c}\text { com IMS - 2 e 3 } \\
\text { dissociações }\end{array}$ & 0,3311 \\
Cryptosporidium parvum & 5 & $\begin{array}{c}\text { com IMS - 2 e 3 } \\
\text { dissociações }\end{array}$ & 0,4226 \\
\hline Giardia spp. & & 0,4226 \\
Cryptosporidium parvum & & & 0,4226 \\
\hline
\end{tabular}

Observando os dados demonstrados na Tabela 65, os métodos apresentaram valores de $\mathrm{p}$ dentro da região crítica $(\mathrm{p}>0,05)$ o que indica, que a hipótese nula deve ser aceita, e conclui-se que as dissociações ácidas não são estatisticamente diferentes, ou seja, a terceira dissociação ácida não fez diferença significativa em ambos os protozoários testados.

Estes dados demonstraram que, com a inclusão da terceira dissociação ácida no procedimento de IMS, a recuperação dos (oo) cistos melhorou, contudo, ainda não foi suficiente para alcançar os padrões estabelecidos no Método 1623.1. E, ainda a introdução desta dissociação também aumenta o custo do ensaio, que será discutido no Item 5.9.

Giglio (2015) em seu ensaio de qualidade do método de FCCa com IMS e duas dissociações atendeu os critérios de aceitação, para ambos os protozoários, condição diferente da abordada nesta pesquisa, onde a inclusão da terceira dissociação não resultou em recuperações que atingissem os padrões internacionais.

Estas diversidades encontradas nos resultados das pesquisas podem estar relacionadas a vários fatores, tais como, variações nos inóculos, matrizes diferentes e, principalmente ao fato de que, nesta pesquisa, a etapa de desinfecção com o ozônio pode destruir e/ou danificar a estrutura dos parasitos, resultando assim, em baixas recuperações. Desta forma, não é possível afirmar quantas dissociações são necessárias para se atingir aos critérios de aceitação imposto pelo método.

Para analisar a influência da inclusão da terceira dissociação ácida no que diz respeito a visualização dos parasitos, algumas imagens capturadas nos ensaios serão apresentadas nas Figuras 51 e 52. 

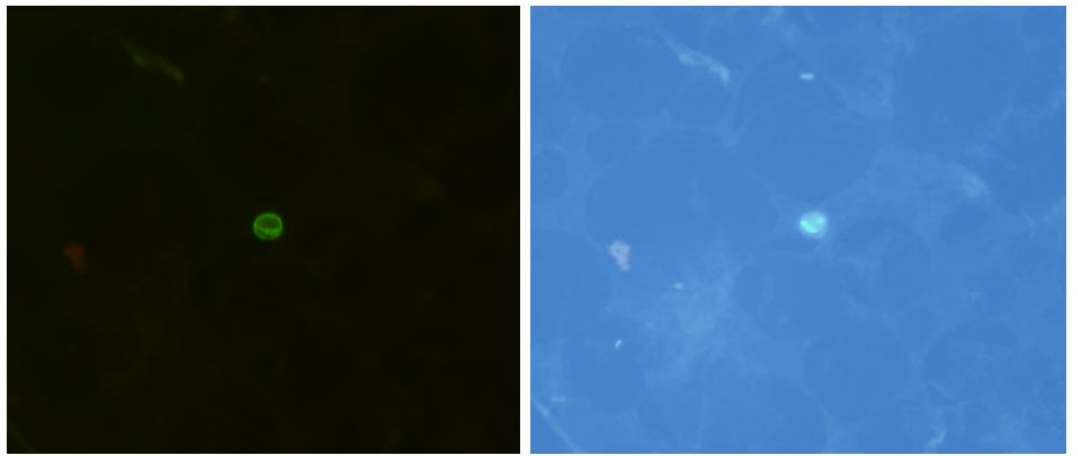

Figura 51: Visualização de oocisto de Cryptosporidium parvum em fluorescência à esquerda e visualização em DAPI à direita na primeira dissociação ácida.
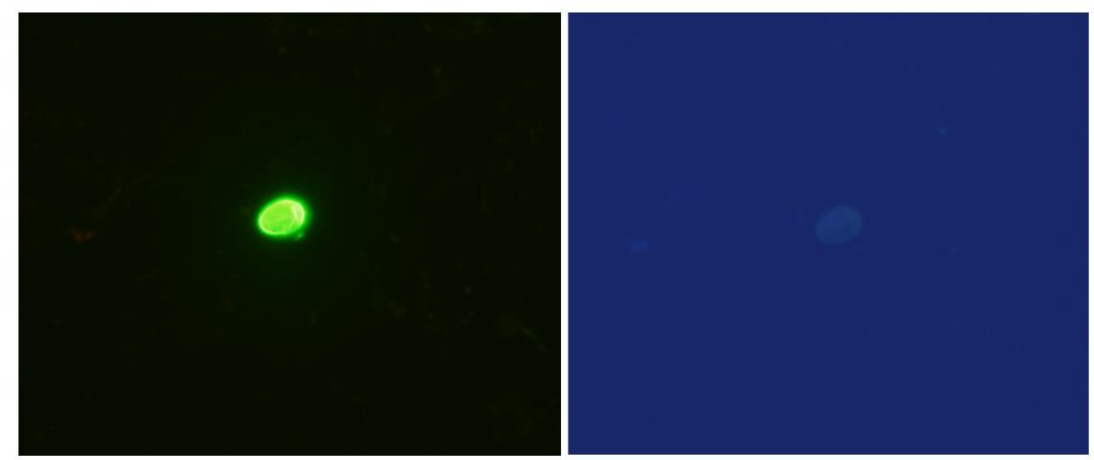

Figura 52: Visualização de cisto de Giardia spp. em fluorescência à esquerda e visualização em DAPI à direita na segunda dissociação ácida.

Nas Figuras 51 e 52 não é possível verificar a influência da primeira e segunda dissociações nos (oo) cistos.

Um fato observado na terceira dissociação, realizadas durante o procedimento de IMS, são algumas deformações na estrutura do parasito (Figura 53).

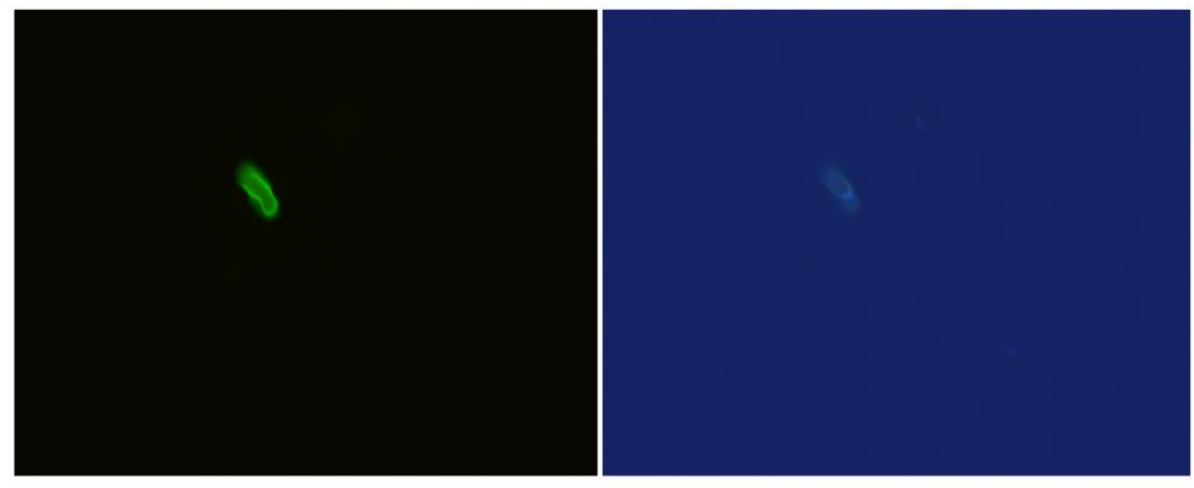

Figura 53: À esquerda, cisto de Giardia spp. com deformidade na membrana visualizado na terceira dissociação ácida e à direita, mesmo cisto visualizado em DAPI (Aumento de $400 \mathrm{x}$ ). 
Estas aparentes deformações estruturais no parasito durante a dissociação, mais precisamente na terceira, pode estar relacionada com o tempo de contato com o ácido $(\mathrm{HCl}-0,1 \mathrm{~N})$, e principalmente, no caso da terceira dissociação, que é a que fica exposta por mais tempo ao ácido.

Apesar da deformidade, em estudo realizado por Rochelle et al., (1999), os pesquisadores relatam que o IMS não interfere na infectividade do parasito, contudo eles trabalharam somente com duas dissociações.

Em vista disso, ensaios específicos sobre viabilidade e infectividade são necessários para afirmar se a introdução da terceira dissociação ácida pode inferir nestes resultados.

\subsection{Avaliação Econômica dos Ensaios Realizados}

A avaliação econômica dos ensaios foi efetuada através do custo médio unitário para a realização dos ensaios de FCCa analisados nesta pesquisa, comparando com e sem a etapa de purificação, e no caso da utilização do IMS, considerando a terceira dissociação ácida.

A análise foi realizada apenas para uma amostra de uma matriz qualquer, e considerou-se somente o uso dos reagentes do kit Merifluor ${ }^{\circledR}$ e Dynabeads ${ }^{\circledR}$. Portanto, são necessárias 3 aplicações do kit Merifluor $^{\circledR}$ para o método de FCCa sem IMS (ensaio em triplicata). Para o método de FCCa com IMS é necessária uma aplicação dos produtos do kit Dynabeads ${ }^{\circledR}$ e duas ou três do kit Merifluor ${ }^{\circledR}$, dependendo se for realizada duas ou três dissociações ácidas.

$\mathrm{Na}$ Tabela 31, do item 5.6.3, estão apresentados os custos unitários de cada aplicação desses reagentes. Com base nesses valores como referência, o custo de cada ensaio foi calculado para uma amostra, atualizado para abril de 2016 no índice IGP-M (FGV). Os resultados obtidos estão na Tabela 66. 
Tabela 66: Valor médio de uma aplicação do método de FCCa com e sem IMS, utilizando 2 ou 3 dissociações ácidas, com dados atualizados para abril de 2016, pelo índice IGP-M (FGV).

\begin{tabular}{|c|c|c|c|c|c|}
\hline Método & Produto & $\begin{array}{l}\text { Valor médio } \\
\text { unitário } \pm \\
\text { Desvio } \\
\text { padrão }(\mathrm{R} \$)\end{array}$ & $\begin{array}{l}\text { Número de } \\
\text { aplicações }\end{array}$ & $\begin{array}{c}\text { Valor por } \\
\text { produto } \pm \\
\text { Desvio } \\
\text { padrão } \\
(\mathrm{R} \$)\end{array}$ & $\begin{array}{l}\text { Valor } \\
\text { total } \\
(\mathrm{R} \$)\end{array}$ \\
\hline \multirow{2}{*}{ FCCa sem IMS } & Merifluor $^{\circledR}$ & $\begin{array}{c}139,12 \pm \\
24,15 \\
\end{array}$ & 3 & $\begin{array}{c}417,36 \pm \\
72,46 \\
\end{array}$ & \multirow{2}{*}{$\begin{array}{r}417,36 \\
\pm 72,46\end{array}$} \\
\hline & Dynabeads $^{\circledR}$ & $\begin{array}{c}416,35 \pm \\
235,89 \\
\end{array}$ & 0 & 0 & \\
\hline \multirow{2}{*}{$\begin{array}{c}\text { FCCa com IMS e } 2 \\
\text { dissociações }\end{array}$} & Merifluor $^{\circledR}$ & $\begin{array}{c}139,12 \pm \\
24,15\end{array}$ & 2 & $\begin{array}{c}278,24 \pm \\
48,31\end{array}$ & \multirow{2}{*}{$\begin{array}{r}694,60 \\
\pm 284,2\end{array}$} \\
\hline & Dynabeads $^{\circledR}$ & $\begin{array}{c}416,35 \pm \\
235,89 \\
\end{array}$ & 1 & $\begin{array}{c}416,35 \pm \\
235,89 \\
\end{array}$ & \\
\hline \multirow{2}{*}{$\begin{array}{c}\text { FCCa com IMS e } 3 \\
\text { dissociações }\end{array}$} & Merifluor $^{\circledR}$ & $\begin{array}{c}139,12 \pm \\
24,15\end{array}$ & 3 & $\begin{array}{c}417,36 \pm \\
72,46\end{array}$ & \multirow{2}{*}{$\begin{array}{c}833,71 \\
\pm \\
308,35\end{array}$} \\
\hline & Dynabeads $^{\circledR}$ & $\begin{array}{c}416,35 \pm \\
235,89 \\
\end{array}$ & 1 & $\begin{array}{c}416,35 \pm \\
235,89 \\
\end{array}$ & \\
\hline
\end{tabular}

Pelos dados demonstrados na Tabela 66, observa-se que a utilização do método FCCa com IMS e duas dissociações ácidas apresentam custo de $40 \%$ a mais, quando comparado com o ensaio de FCCa sem IMS, e ainda custo de 50\% maior, se comparado com o ensaio de FCCa com IMS e três dissociações ácidas.

E analisando os procedimentos de FCCa com IMS, com duas ou três dissociações, nota-se um aumento nos custos de aproximadamente 16,7\% quando a terceira dissociação ácida é utilizada.

Maciel e Sabogal Paz (2016) realizaram a análise de custo unitário dos reagentes, considerando somente $o$ kit Merifluor $^{\circledR}$ e Dynabeads ${ }^{\circledR}$ e reportaram aumento de aproximadamente $4 \%$ quando o IMS foi utilizado.

Enfim, essa análise torna evidente que os ensaios de FCCa com IMS possuem custos muito mais elevados, quando comparados com os ensaios sem a etapa de purificação. 


\section{CONCLUSÕES}

O tratamento de ciclo completo com flotação e filtração utilizado para água com turbidez de 50 uT e cor aparente de 80 Pt-Co, obteve valores na água final que se enquadram no padrão de potabilidade da Portaria MS no 2914/2011.

A dosagem de PAC utilizada foi eficiente na remoção de parâmetros físico-químicos presentes na água de estudo.

Ao comparar os valores de Giardia spp. para o azul de tripano e para o IP, observou-se que a diferença estatística não foi significativa ( $\mathrm{p}>0,05)$, ou seja, não houve variabilidade entre os métodos testados e os valores obtidos são similares, justificando assim o uso do IP.

Em relação ao tempo do corante IP, concluiu-se que quanto maior o tempo de contato com o IP, menor é a porcentagem de (oo) cistos não corados (viáveis), o que pode indicar resultados falso-positivos, provocados pela longa exposição ao corante, e com isso, inferir na viabilidade dos parasitos. Portanto, o tempo de contato de 5 min foi o mais indicado, pela maior porcentagem de organismos que não penetraram o corante neste período.

Para os ensaios do controle de qualidade do método FCCa, utilizando o kit Easyseed, a recuperação de Giardia spp. para os métodos sem IMS e com IMS e três dissociações, ambos alcançaram valores que atenderam aos padrões do Método 1623.1, e somente o ensaio com IMS e duas dissociações, não atendeu os padrões estabelecidos. A recuperação de Cryptosporidium parvum para os 3 métodos apresentados, não houve conformidade com os critérios do Método 1623.1.

Em relação à ozonização, para os ensaios realizados na Etapa 1, que se utilizou $5 \mathrm{mgO}_{3} \mathrm{~L}^{-1}$ e tempo de contato de 1 min sem a realização da etapa de IMS, as maiores inativações atingidas foram de 2,52 e 2,22 log de inativação para cistos de Giardia spp. e oocistos de Cryptosporidium parvum, respectivamente. Quando se comparou com o tempo de contato de $5 \mathrm{~min}$, as maiores inativações foram de 2,52 e 2,92 log de inativação de cistos de Giardia spp. e oocistos de Cryptosporidium parvum, respectivamente.

Na Etapa 2, com a inclusão da etapa de IMS, utilizando a mesma dosagem e tempo de contato de 1 min, obteve-se 2,27 e $0,21 \log$ de inativação para cistos e oocistos, respectivamente. Comparando-se com o tempo de contato de $5 \mathrm{~min}$, as 
maiores desinfecções foram de 2,9 e 2,3 log de inativação para cistos e oocistos, respectivamente.

A partir dos dados obtidos nas etapas analisadas, os tempos de contato de 1 e 5 min utilizados nos ensaios de ozonização, não apresentaram diferenças significativas entre eles, ou seja, os tempos adotados se comportaram da mesma forma na inativação de Giardia spp. e Cryptosporidium parvum.

A inclusão da terceira dissociação ácida na etapa de IMS não incrementou consideravelmente a recuperação de (oo) cistos.

Quanto ao custo individual de cada ensaio, os ensaios de FCCa sem IMS são mais econômicos em relação aos ensaios com a etapa de purificação. Ao utilizar o IMS os custos aumentam em $40 \%$ quando são empregadas duas dissociações ácidas e em 50\% quando são realizadas três dissociações ácidas. 


\section{RECOMENDAÇÕES}

Avaliar outro método de concentração, como a filtração em membranas, que também possui baixo custo, demanda menor tempo laboratorial e preserva a morfologia dos oocistos.

Substituir o procedimento de separação imunomagnética (IMS) por um processo mais acessível e viável financeiramente.

Testar outras dosagens e tempo de contato na desinfecção com ozônio. 


\section{REFERÊNCIAS BIBLIOGRÁFICAS}

ABOYTES, R., DIGIOVANNI, G. D., ABRAMS, F. A., RHEINECKER, C., MACELROY, W., SHAW N., LECHEVALLIER, M. W. Detection of infectious Cryptosporidium in filtered drinking water. Journal of the American Water Works Association, v. 96, n. 9, p. 88-98, 2004.

ALDEYARBI, H. M.; KARANIS, P. Electron microscopic observation of the early stages of Cryptosporidium parvum asexual multiplication and development in in vitro axenic culture. European Journal of Protistology, v. 52, p. 36-44, 2016.

APHA; AWWA; WEF. Standard Methods for the Examination of Water and Wastewater. 22nd ed. Washington, DC, 2012.

ASSAVASILAVASUKUL, P., LAU, B. L., HARRINGTON, G. W., HOFFMAN, R. M., BORCHARDT, M. A. Effect of pathogen concentrations on removal of Cryptosporidium and Giardia by conventional drinking water treatment. Water Research, v. 42, n. 10, p. 2678-2690, 2008.

BAStOS, R. K. X.; BEVILACQUA, P. D.; KELlER, R. Desinfecção de Efluentes Sanitários. In: GONÇALVES, R.F. (Coord.). Organismos Patogênicos e Efeitos Sobre a Saúde Humana. ABES, 2003. Cap. 2, p. 27 - 88. (Projeto PROSAB).

BASTOS, R. K. X.; BRANDÃO, C. C. S.; CERQUEIRA, D. A. Tratamento de Água e Remoção de Protozoários. In: PÁDUA, L. P. (Coord.). Remoção de microrganismos emergentes e microcontaminantes orgânicos no tratamento de água para consumo humano. Rio de Janeiro: ABES, 2009. cap. 4, p.109-150. (Projeto PROSAB).

BENETTI, A. D.; DE LUCA, S. J.; CYBIS, L. F. Tratamento de Água e Remoção de Protozoários. In: PÁDUA, L. P. (Coord.). Remoção de gosto e odor em processos de tratamento de água. Rio de Janeiro: ABES, 2009. cap. 8, p.293-326. (Projeto PROSAB). 
BETANCOURT, W. Q.; GENNACCARO, A. L.; SCOTT, T. M.; ROSE, J. B. Assessment of methods for detection of infectious Cryptosporidium oocysts and Giardia cysts in reclaimed effuents. Applied and Environmental Microbiology. Vol. 69, n.9, p. 53805388, 2003.

BEVILACQUA, P.D.; AZEVEDO, S.M.F.O.; CERQUEIRA, D. A. Microrganismos Emergentes: Protozoários e Cianobactérias. In: PÁDUA, L. P. (Coord.). Remoção de microrganismos emergentes e microcontaminantes orgânicos no tratamento de água para consumo humano. Rio de Janeiro: ABES, 2009. cap. 3, p.74-108. (Projeto PROSAB).

BONATTI, R. T. Ocorrência de cistos de Giardia spp., oocistos de Cryptosporidium spp. e ovos da família Ascarididae em amostras de lodo de esgoto. Dissertação (Mestrado) Campinas, SP - 2007.

BUKHARI, Z.; MCCUIN, R. M.; FRICKER, C. R.; CLANCY, J. L. Immunomagnetic separation of Cryptosporidium parvum from source water samples of various turbidities. Applied and Environmental Microbiology, v. 64, n. 11, p. 4495-4499, 1998.

BRESCIA, C. C.; GRIFFIN, S. M.; WARE, M.W.; VARUGHESE, E. A.; EGOROV, A. I.; VILLEGAS, E. N., Cryptosporidium Propidium Monoazide-PCR, a Molecular Biology-Based Technique for Genotyping of Viable Cryptosporidium Oocysts. Applied and Environmental Microbiology, v. 75, n. 21, p. 6856-6863, Nov 2009.

CAETANO, J. F.; LOPES, W. R. D. Avaliação da eficiência do coagulante cloreto de polialumínio na ETA Alto da Boa Vista, como alternativa ao sulfato e cloreto férricos. $19^{\circ}$ ENCONTRO TÉCNICO AESABESP. São Paulo, 2009.

CACCIÒ, S. M.; THOMPSON, R. C. A.; MCLAUCHLIN, J.; SMITH, H. V. Unravelling Cryptosporidium and Giardia epidemiology. Trends in Parasitology, v. 21, n. 9, p. 430-437, 2005.

CACCIÒ, S. M.; DE GIACOMO, M.; AUliCINO, F. A.; POZIO, E. Giardia cysts in wastewater treatment plants in Italy. Applied and Environmental Microbiology, v. 69, n. 
6, p. 3393-3398, 2003.

CACCIÒ, S. M.; SPRONG, H. Epidemiology of Giardiasis in Humans in LUJÀN, H.D.; SVARD, S. editors Giardia: A model Organism. Springer, 2011.

CACCIÒ, S.; PUTIGNANI, L. Epidemiology of human Cryptosporidiasis in CACCIÒ, S. M.; WIDMER, G. editors, 2014. Cryptosporidium: parasite and disease. Springer, 2014.

CAMEL, V.; BERMOND, A. The use of Ozone and Associated Oxidation Processes in Drinking Water Treatment. Water Research. v. 32, n. 11, p. 3208 - 3222, 1998.

CAMPBELL, A. T.; ROBERTSON, L. J.; SMITH, H. V. Viability of Cryptosporidium parvum oocysts: Correlation of in vitro excystation with inclusion or exclusion of fluorogenic vital dyes. Applied and Environmental Microbiology, v. 58, n. 11, p. 34883493, 1992.

CANTUSIO NETO, R.; SANTOS, L.U.; SATO, M.I.Z., FRANCO, R.M.B., Cryptosporidium spp. and Giardia spp. in surface water supply of Campinas, Southeast Brazil. Water Science and Technology, v. 62, n. 1, p. 217-222, 2010.

CANTUSIO NETO, R. Estudo dos métodos: floculação em carbonato de cálcio e adaptação das técnicas de filtração em membrana e separação imunomagnética para a detecção de Cryptosporidium e Giardia em amostras hidricas. 2008. 130 p. Tese (Doutorado em Parasitologia). Instituto de Biologia, Universidade Estadual de Campinas, Campinas.

CASTRO-HERMIDA, J. A.; GARCÍA-PRESEDO, I.; GONZÁLEZ-WARLETA, M.; MEZO, M. Cryptosporidium and Giardia detection in water bodies of Galicia, Spain. Water Research, v. 44, n. 20, p. 5887-5896, 2010.

CORRÊA, A. C. F.; VIANA, M.; FIGUEIREDO, T.; BORGES, J.; LIBÂNIO, M. I-137

- Perspectiva De Alteração De Coagulante Para Estação de Tratamento de Água Operando com Sobregarga. p. 1-9, 
COSTA, H.; DANIEL, L. (Coord.). Desinfecção de efluentes sanitários, remoção de patógenos e remoção de substâncias nocivas. Vitória: PROSAB, 2002.

DANIEL, L. A. (Coord.). Métodos Alternativos de Desinfecção da Água. Processos de Desinfecção e Desinfetantes Alternativos na Produção de Água Potável. São Carlos: RiMa: 2001.139 p. (Projeto PROSAB)

DA SILVA, S. B.; DE MEllo LUVIElMO, M.; GEYER, M. C.; PRÁ, I. Potencialidades do uso do ozônio no processamento de alimentos. Semina: Ciências Agrárias, v. 32, n. 2, p. 659-682, 2011.

DI BERNARDO, L.; DANTAS, A. D. B.; VOLTAN, P. E. N. Tratabilidade de água e dos resíduos gerados em estações de tratamento de água. São Carlos: Editora LDiBe, 2011.

DOWD, S. E.; PILLAI, S. D. A rapid viability assay for Cryptosporidium oocysts and Giardia cysts for use in conjunction with indirect fluorescent antibody detection. Canadian journal of microbiology, v. 43, n. 7, p. 658-662, 1997.

EDZWALD, J.; HAARHOFF, J. Dissolved air flotation for water clarification. McGraw Hill Professional, 2011.

EDZWALD, J. K.; WALSH, J. P.; KAMINSKI, G. S.; DUNN, H. J.; Flocculation and Air requeriments for dissolved air flotation. American Water Works Association, v. 84, n. 3, p. 92-100, 1992.

FAGNANI, R. A. G. Avaliação de dano morfológico em oocistos de Cryptosporidium spp. e cistos de Giardia spp. pela ação da peroxidação assistida por luz ultravioleta (H2O2/UV). Dissertação (Mestrado). Universidade Estadual de Campinas, 2010.

FAYER, R. Cryptosporidium: a water-borne zoonotic parasite. Veterinary Parasitology, v. 126, n. 1-2, p. 37-56, Dec 2004. 
FENG, Y.; XIAO, L. Zoonotic Potential and Molecular Epidemiology of Giardia Species and Giardiasis. Clinical Microbiology Reviews, v. 24, n. 1, 2011, ISSN 08938512; p. 1098-6618, 2011.

FENG, Y.; ZHAO, X.; CHEN, J.; JIN, W.; ZHOU, X.; LI, N.; WANG, L.; XIAO, L. Occurrence, source, and human infection potential of Cryptosporidium and Giardia spp. in source and tap water in Shanghai, China. Applied and environmental microbiology, v. 77, n. 11, p. 3609-16, 2011.

FERREIRA FILHO, S. S.; WAELKENS, B. E. Minimização da produção de lodo no tratamento de águas de abastecimento mediante uso do cloreto de polialumínio e sua disposição em estações de tratamento de esgotos. Engenharia Sanitária e Ambiental, v. 14, no 3, p. 317-326, 2009.

FERRARI, T. N.; DE JULIO, M.; DE JULIO, T. S. Emprego do Sulfato de alumínio e do cloreto de polialumínio em estudos de tratabilidade da água que abastece o município de São José dos Campos - SP. Engenharia Ambiental - Espírito Santo do Pinhal, v. 8, n. 4, p. 118-137, 2011.

FINCH, G. R.; BLACK, E. K.; LABATIUK, C. W.; GYUREK, L; BELOSEVIC, M. Comparison of Giardia lamblia and Giardia muris cyst inactivation by ozone. Applied and Environmental Microbiology, v. 59, n. 11, p. 3674-3680, 1993.

FRANÇA, R. B. Cryptosporidium spp., Giardia spp. e ovos de helmintos em esgoto hospitalar: destruição e analise de dano estrutural dos protozoários após o processo fotoeletroquimico. $159 \mathrm{p}$ (Mestrado em Parasitologia). Instituto de Biologia, Universidade Estadual de Campinas, Campinas, 2007.

FRANCO, R. M. B. Protozoários de veiculação hídrica: relevância em saúde pública. Revista Panamericana de Infectologia, v.4, p. 36-43, 2007.

FRANCO, R. M. B.; BRANCO, N.; LEAL, D. A. G. Parasitologia Ambiental: Métodos de Concentração e Detecção de Cryptosporidium spp. e Giardia spp. em Amostras de Água. Revista de Patologia Tropical, v. 41, n. 2, 2012. 
FRANCO, R. M. B.; ROCHA-EBERHARDT, R.; CANTUSIO NETO, R. Occurrence of Cryptosporidium oocysts and Giardia cysts in raw water from the Atibaia river, Campinas, Brazil. Revista do Instituto de Medicina Tropical de São Paulo, v. 43, n. 2, p. 109-111, 2001.

FRANCO, R. M. B.; HACHICH, E. M.; SATO, M. I. Z. S.; NAVEIRA, R. M. L.; SILVA, E. D. C.; CAMPOS, M. M. D. C.; CANTÚSIO NETO, R.; CERQUEIRA, D. A.; BRANCO, N.; LEAL, D. A. G. Avaliação da performance de metodologias de detecção de Cryptosporidium spp. e Giardia spp. em água destinada ao consumo humano, para o atendimento às demandas da Vigilância em Saúde Ambiental no Brasil. Epidemiologia e Serviços de Saúde, v. 21, n. 2, p. 233-242, 2012.

FREIRE-SANTOS, F.; OTEIZA-LÓPEZ, A. M.; VERGARA-CASTIBLANCO, C. A.; ARES-MAZÁS, E. Study of the combined influence of environmental factors on viability of Cryptosporidium parvum oocysts in water evaluated by fluorogenic vital dyes and excystation techniques. Veterinary Parasitology, v. 89, n. 4, p. 253-259, 2000.

GASSER, R. B.; O'DONOGHUE, P. E. Isolation, propagation and characterisation of Cryptosporidium. International Journal for Parasitology, v. 29, n. 9, p. 1379-1413, 1999.

GIGLIO, G. L. Avaliação de diversos métodos de detecção de cistos de Giardia spp. e Cryptosporidium parvum presentes no resíduo gerado após o tratamento de água de abastecimento com turbidez elevada. Dissertação (Mestrado). Escola de Engenharia de São Carlos, 2015.

GUERDEN, T.; OLSON, M. Giardia in pets and farm animals, and their zoonotic potential in humans in: LUJÀN, H. D.; SVÄRD, S. editors, Giardia: A model Organism. Springer, 2011.

HEIN, I.; SCHNEEWEISS, W.; STANEK C.; WAGNER, M. Ethidium monoazide and propidium monoazide for elimination of unspecific DNA background in quantitative universal real-time PCR. Journal of microbiological methods, v. 71, n. 3, p. 336-339, 2007. 
HELlER, L.; BASTOS R. K. X.; VIEIRA, M. B. C. M.; BEVILACQUA, P. D.; BRITO, L. L. A.; MOTA, M. M. M.; OLIVEIRA; A. A.; MACHADO, P. M.; SALVADOR, D. P.; CARDOSO, A. B. Oocistos de Cryptosporidium e cistos de Giardia: circulação no ambiente e riscos à Oocistos de Cryptosporidium e cistos de Giardia: circulação no ambiente e riscos à saúde humana. Epidemiologia e Serviços de Saúde, v. 13, n. 2, p. 79-92, 2004.

HSU, B. M.; YEH, H. H. Removal of Giardia and Cryptosporidium in drinking water treatment: A pilot-scale study. Water Research, v. 37, n. 5, p. 1111-1117, 2003.

KARANIS, P.; KOURENTI, C.; SMITH, H. WATERBORNE transmission of protozoan parasites: A worldwide review of outbreaks and lessons learnt. Journal of Water and Health, v. 5, n. 1, p. 1-38, Mar 2007.

KEEGAN, A.; DAMINATO, D.; SAINT, C. P.; MONIS, P. T. Effect of water treatment processes on Cryptosporidium infectivity. Water Research, v. 42, n. 6-7, p. 1805-1811, 2008

KHALIFA, A. M.; EL TEMSAHY, M. M.; ABOU, E. N. I. F. Effect of ozone on the viability of some protozoa in drinking water. Journal of the Egyptian Society of Parasitology, v. 31, n. 2, p. 603, 2001.

KORICH, D. G.; MEAD, J. R.; MADORE, M. S.; SINCLAIR, N. A.; STERLING, C. R. Effects of ozone, chlorine dioxide, chlorine, and monochloramine on Cryptosporidium parvum oocyst viability. Applied and Environmental Microbiology, v. 56, n. 5 , p. $1423-1428,1990$.

LABATIUK, C. W.; SCHAEFER, F. W.; FINCH, G. R.; BELOSEVIC, M. Comparison of animal infectivity, excystation, and fluorogenic dye as measures of Giardia muris cyst inactivation by ozone. Applied and Environmental Microbiology, v. 57, n. 11, p. 3187-3192, 1991. 
LADEIA, M. M.; HELLER, L.; VIEIRA, M. B. C. M. (2005). Pesquisa de (oo) cistos de protozoários em amostras de águas de mananciais superficiais de Montes Claros/MG. In: Congresso Brasileiro de Engenharia Sanitária e Ambiental, 23. 9p. Campo Grande. 2005.

LANGLAIS, B; RECKHOW, D. A.; BRINK, D. R. (1991) Ozone in water treatment: aplicattion and engineering. Michigan: Lewis Publishers, 298 p.

LAPOLLI, F. R.; SANTOS, L. F.; HÁSSEMER, M. E. N.; AISSE, M. M.; PIVELI, R. P. Desinfecção de efluentes sanitários por meio da ozonização. In. GONÇALVES, R. F. (Coord.). Desinfecção de efluentes sanitários, remoção de organismos patógenos e substâncias nocivas: aplicação para fins produtivos como agricultura, aqüicultura e hidropônica. Vitória: PROSAB, 2003. p. 169-208.

LeCHEVALLIER, M. W.; NORTON, W. D.; LEE, R. G. Giardia and Cryptosporidium spp. in filtered drinking water supplies. Applied and Environmental Microbiology, v. 57, n. 9, p. 2617-2621, 1991.

LEITCH, G. J.; HE, Q. Cryptosporidiosis-an overview. Journal of Biomedical Research, v.25, n.1, 2011.

LIBÂNIO, M. Fundamentos de qualidade e tratamento de água. Campinas: Editora Átomo, 2008.

LOPES, F. M. F.; CORAL, L. A.; LAPOLLI, F. R.; ALMEIDA DUARTE, E.; MARNOTO, M. J. E. Comparação da Flotação por Ar Dissolvido e Sedimentação no Tratamento de Água Utilizando Policloreto de Alumínio. In: CONGRESSO BRASILEIRO DE ENGENHARIA SANITÁRIA E AMBIENTAL, 25. 2009, Recife. Anais eletrônicos: I-111.

LOPES, G. J. R. Avaliação da turbidez e do tamanho de partículas como parâmetros indicadores da remoção de oocistos de Cryptosporidium spp. nas etapas de clarificação no tratamento da água em ciclo completo. 128 p. Dissertação (Mestrado em Engenharia Civil). Universidade Federal de Viçosa, Viçosa, 2008. 
MACIEL, P. M. F.; SABOGAL-PAZ, L. P. Removal of Giardia spp. and Cryptosporidium spp. from water supply with high turbidity: analytical challenges and perspectives. Journal of Water and Health, v. 14, n. 3, p. 369-378, 2016.

MCCUIN, R. M.; CLANCY, J. L. Modi cations to United States Environmental Protection Agency Methods 1622 and 1623 for Detection of Society, v. 69, n. 1, p. 267$274,2003$.

MACIEL, P. M. F. Remoção de Giardia spp. e Cryptosporidium spp. em águas de abastecimento com turbidez elevada utilizando cloreto de polialumínio: estudo em escala de bancada. Dissertação (Mestrado). Escola de Engenharia de São Carlos, 2014.

MALLEY, J. P. JR, Edzwald, J. K. Laboratory Comparison of DAF With Conventional Treatment. Journal-American Water Works Association, v. 83, n. 9, p. 56-61, 1991.

MARQUES, A. D.; PEREIRA, D. S. C. DE A.; COVRE, M. A.; GONÇALVES, R. F.; KELLER, R. Remoção de Cryptosporidium spp. e Giardia lamblia em águas de abastecimento. In: CONGRESSO BRASILEIRO DE ENGENHARIA SANITÁRIA E AMBIENTAL, 23. 2005, Campo Grande. Anais eletrônicos: I-053.

MEDEIROS, R. C. Comparação da resistência de protozoários patogênicos - Giardia spp. e Cryptosporidium spp. - e de microrganismos indicadores à desinfecção sequencial cloro-radiação ultravioleta e ozônio-radiação ultravioleta. 210 p. Dissertação (Mestrado em Ciências - Engenharia Hidráulica e Saneamento). Escola de Engenharia de São Carlos, Universidade de São Paulo, São Carlos, 2010.

MIRANDA, N. D. Ozonização e Peroxização de Efluente Sanitário Proveniente de Alagados Construídos e Reator Compartimentado Anaeróbio/Aeróbio Visando Reuso. Dissertação (Mestrado) - Universidade Estadual Paulista. Faculdade de Engenharia, Bauru, 2014. 
M.S (Ministério da saúde). Portaria No 2914 DE 12/12/2011 (Federal). Dispõe sobre os procedimentos de controle e de vigilância da qualidade da água para consumo humano e seu padrão de potabilidade.

OLVERA, M.; EGUÍA, A.; RODRÍGUES, O.; CHONG, E.; PILlAI, S. D.; ILANGOVAN, K. Inactivation of Cryptosporidium parvum oocysts in water using ultrasonic treatment. Bioresource Technology. Vol. 99, p. 2046-2049, 2008

OLVERA, M.; ILANGOVAN, K. Disinfection of Cryptosporidium parvum oocysts in water using ultrasonic treatment. Research Centre for Environmental Quality, ITESMCEM. v. 2, p. 118-121, 2008.

REALI, M. A. P.; MORUZZI, R. B.; PATRIZZI, L. J. Flotação Por Ar Dissolvido Aplicada Na Clarificação De Águas que Apresentam Picos de Turbidez. n. 1, p. 1-9, I022. ABES- 2003.

PASSOS, T. M.; DA SILVA, L. H. M.; MOREIRA, L. M.; ZÂNGARO, R. A.; DA SILVA SANTOS, R.; FERNANDES, F. B.; DE LIMA, C. J.; FERNANDES, A. B. Comparative Analysis of Ozone and Ultrasound Effect on the Elimination of Giardia spp. cysts from Wastewater. Ozone: Science \& Engineering, 36: 138-143. March April 2014

PAVANELLI, G (2001). Eficiência de Diferentes Tipos de Coagulantes na Coagulação, Floculação e Sedimentação de Água com Cor ou Turbidez Elevada. Dissertação (mestrado). Escola de Engenharia de São Carlos. Universidade de São Paulo EESC/USP. Brasil.

PLUMMER, J. D.; EDZWALD, J. K.; KELLEY, M. B. Removing Cryptosporidium by dissolved-air flotation. Journal-American Water Works Association, v. 87, n. 9, p. 8595, 1995.

QUINTERO-BETANCOURT, W.; GENNACCARO, A. L.; SCOTT, T. M.; ROSE, J. B. Assessment of Methods for Detection of Infectious Cryptosporidium Oocysts and Giardia Cysts in Reclaimed Effluents. Applied and Environmental Microbiology, v. 69, 
n. 9 , p. $5380-5388,1$ set. 2003.

RAKNESS, K.; GORDON， G.; LANGLAIS， B.; MASSCHELEIN， W.; MATSUMOTO, N.; RICHARD, Y.; ROBSON, C. M.; SOMIYA, I. Guideline for measurement of ozone concentration in the process gas from an ozone generator. Ozone Science and Engineering, v.18, p. 209-229, 1996.

ROBERTSON, L. J.; PATON, C. A.; CAMPBELL, A T.; SMITH, P. G.; JACKSON, M. H.; GILMOUR, R. A.; BLACK, S. E.; STEVENSON, D. A.; SMITH, H. V. Giardia cysts and Cryptosporidium oocysts at sewage treatment works in Scotland, UK. Water Research, v. 34, n. 8, p. 2310-2322, jun. 2000.

ROCHELLE, P. A.; DE LEON, R.; JOHNSON, A.; STEWART, M. H.; WOLFE, R. L. Evaluation of immunomagnetic separation for recovery of infectious Cryptosporidium parvum oocysts from environmental samples. Applied and Environmental Microbiology, v. 65, n. 2, p. 841-845, 1999.

RYAN, U.; CACCIÒ, S. M. Zoonotic potential of Giardia. International Journal for Parasitology, v. 43, n. 12-13, p. 943-956, 2013.

SALVADOR, D. P.; CARDOSO, A. B. Oocistos de Cryptosporidium e cistos de Giardia: circulação no ambiente e riscos à Oocistos de Cryptosporidium e cistos de Giardia: circulação no ambiente e riscos à saúde humana. Epidemiologia e Serviços de Saúde, v. 13, n. 2, p. 79-92, 2004.

SANTOS, L. U. dos. Ocorrência de oocistos de Cryptosporidium spp. e cistos de Giardia spp. em uma Estação de Tratamento de Esgoto: avaliação das eficiências do processo de lodo ativado na remoção e de desinfecção por luz ultravioleta na inativação desses patógenos. p. 150, 2007.

SANTOS, L. U. D.; CANTUSIO NETO, R.; FRANCO, R. M. B. Protozoários patogênicos de veiculação hídrica: as metodologias de detecção em amostras de esgoto 
e a eficiência dos tratamentos de remoção e desinfecção. Higiene Alimentar, v. 22, n. Edição Temática, p. 22-28, 2008.

SANTOS, L. U.; CANTUSIO NETO, R.; FRANCO, R. M. B.; GUIMARÃES, J. R. Detecção de oocisto de Cryptosporidium spp. e cistos de Giardia spp. em amostras de esgoto bruto ou tratado: avaliação crítica dos métodos. Engenharia Sanitária e Ambiental, v. 16, n. 2, p. 115-120, 2011.

SANTOS, P. R. Ocorrência e remoção de protozoários patogênicos Giardia spp. e Cryptosporidium spp. em sistemas de tratamento de esgoto sanitário. Dissertação (Mestrado). Universidade de São Paulo, São Carlos, 2015.

SCHUPP, D. G.; ERLANDSEN, S. L. A new method to determine Giardia cyst viability: Correlation of fluorescein diacetate and propidium iodide staining with animal infectivity. Applied and Environmental Microbiology, v. 53, n. 4, p. 704-707, 1987.

SILVA, G. H. R.; DANIEL, L. A.; BRUNING, H.; RULKENS, W. H. Anaerobic effluent disinfection using ozone: Byproducts formation. Bioresource Technology, v. 101, n. 18, p. 6981-6986, 2010.

SILVA, E. G. P.; NASCIMENTO, S. G.; AGUIAR, J. H. S. O.; SHINDO, N.; GINO, M. A. P. Uso do Cloreto de Polialumínio na Estação de Tratamento de Água - Guaraú. In: CONGRESSO BRASILEIRO DE ENGENHARIA SANITÁRIA E AMBIENTAL, 25, 2009, Recife. Anais eletrônicos: I-034.

SILVEIRA, I. C. T. Cloro e ozônio aplicados a desinfecção de efluente hospitalar tratado em contadores biológicos rotatórios, com avaliação de efeitos tóxicos em DAPHNIA SIMILIS. 2004. Dissertação (Doutorado em Recursos Hídricos e Saneamento Ambiental) - Universidade do Rio Grande do Sul, Porto Alegre.

SOARES, L. V. Ozonização de esgoto sanitário: estudo de hidrodinâmica, transferência de massa e inativação de microorganismos indicadores. (Tese de Doutorado) Programa de Pós-Graduação na área de Engenharia Hidráulica e Saneamento. Universidade de São Paulo (USP), 2007. 
SOUZA, J. B. (2006). Avaliação de métodos para desinfecção de água, empregando cloro, ácido peracético, ozônio e o processo de desinfecção combinado ozônio/cloro. Tese de Doutorado, Escola de Engenharia de São Carlos, Universidade de São Paulo.

SMITH, H. V.; GRIMASON, A. M. Giardia and Cryptosporidium in water and wastewater. In: MARA, D.; HORAN, N. (Ed.). The Handbook of Water and Wastewater Microbiology. London: Elsevier, 2003. cap 40. p. 695-756.

SMITH, H. V.; NICHOLS, R. A. B.; GRIMASON, A. M. Cryptosporidium excystation and invasion: Getting to the guts of the matter. Trends in Parasitology, v. 21, n. 3, p. $133-142,2005$.

SWERTFEGER, J.; METZ, D. H.; DEMARCO, J.; BRAGHETTA, A.; JACANGELO, J. G. Effect of filter media on cyst and oocyst removal. Journal / American Water Works Association, v. 91, n. 9, p. 90-100, 1999.

TEUNIS, P. F. M.; MEDEMA, G. J.; KRUIDENIER, L.; HAVELAAR, A. H. Assessment of the risk of infection by Cryptosporidium or Giardia in drinking water from a surface water source. Water Research, v. 31, n. 6, p. 1333-1346, 1997.

UNITED STATES ENVIRONMENTAL PROTECTION AGENCY (USEPA). Alternative Disinfectants and Oxidants Guidance Manual. Office of Water. EPA 815-R99-014. Washington, DC, 1999.

UNITED STATES ENVIRONMENTAL PROTECTION AGENCY (USEPA). Method 1623.1 Cryptosporidium and Giardia in Water by Filtration/IMS/FA. Office of Water (MS-140) EPA 816 -R-12-001. Washington, DC, January 2012.

VALADE, M. T.; BECKER, W. C.; EDZWALD, J. K. Treatment Selection Guidelines for Particle and NOM Removal, Journal of Wather Supply: Research and Technology Aqua, 2009. 
VESEY G., SLADE J. S., BYRNE M., SHEPPERD K., FRICKER C. R. A new method for the concentration of Cryptosporidium oocysts from water. Journal of Applied Bacteriology, v.75, p.82-86, 1993.

VERGARA-CASTIBLANCO, C. A.; FREIRE-SANTOS, F.; OTEIZA-LÓPEZ, A. M.; ARES-MAZÁS, M. E. Viability and infectivity of two cryptosporidium parvum bovine isolates from different geographical location. Veterinary Parasitology, v. 89, n. 4, p. 261-267, 2000.

VIEIRA, R. Remoção de microalgas por pré-ozonização e flotação por ar dissolvido. Dissertação (Mestrado). Escola de Engenharia de São Carlos, 2016.

WICKRAMANAYAKE, G. B.; RUBIN, A. J.; SPROUL, O. J. Inactivation of Giardia lamblia cysts with ozone. Applied and Environmental Microbiology, v. 48, n. 3, p. 671$672,1984$.

WIDMER, G.; ClANCY, T.; WARDT, H. D.; MILlER, D.; BATZER, G. M.; PEARSON, C. B. Structural and Biochemical Alterations in Giardia lamblia Cysts Exposed to Ozone. Journal of Parasitology v. 88, n. 6, p. 1100-1106, 2002.

WHO World Health Organization. Guidelines for Drinking - Water Quality - 4th ed. 2011

YAOYU, F.; XIAO, L. Zoonotic potential and molecular epidemiology of Giardia species and giardiasis. Clinical Microbiology Reviews, v. 24, n. 1, p. 110-140, 2011.

ZERBINI, A. M.; CHERNICHARO, C. A. L.; VIANA, E. M. Estudo Da Remoção De Ovos De Helmintos E Indicadores Bacterianos Em Um Sistema De Tratamento De Esgotos Domésticos Por Reator Anaeróbio e Aplicação Superficial no Solo. Engenharia Sanitária e Ambiental, I-159 p. 895-904, 1989. 


\section{APÊNDICES}

Apêndice A - Métodos e equipamentos utilizados para caracterização da água de estudo

\begin{tabular}{|c|c|c|}
\hline Análise & Parâmetros & Métodos e equipamentos \\
\hline \multirow{16}{*}{$\begin{array}{c}\text { Análises de rotina } \\
\text { (LATAR) }\end{array}$} & & Titulação potenciométrica com ácido \\
\hline & & sulfúrico até $\mathrm{pH} \quad 4,30$ (Método \\
\hline & Alcalinidade total & 2320B) \\
\hline & Condutividade & Condutivímetro DM-32 \\
\hline & & Colorímetro \\
\hline & Cor aparente & Digimed $^{\circledR}$ \\
\hline & & Espectrofotômet \\
\hline & Cor verdadeira & ro DR-2800 \\
\hline & Dureza & Titulação \\
\hline & Ozônio dissolvido & Espectrofotômetro DR-2800 \\
\hline & \multirow{3}{*}{$\mathrm{pH}$} & Qualxtron e eletrodo \\
\hline & & 8102BNUWP conectado ao pHmetro \\
\hline & & Digimed $®$ (Método potenciométrico) \\
\hline & Potencial zeta (pZ) & Zetasizer Nano - ZS90, Malvern \\
\hline & Temperatura & Termômetro de mercúrio \\
\hline & Turbidez & Turbidímetro Hach-2100N \\
\hline Análises ocasionais & Alumínio & Método $3111 \mathrm{D}$ \\
\hline (Laboratório de & Cálcio & \\
\hline Saneamento) & Cádmio & Método $3111 \mathrm{~B}$ \\
\hline
\end{tabular}


Chumbo

Ferro

Magnésio

Manganês

Mercúrio Método 3112 B

Coliformes totais

Escherichia coli

Método 2923 B Colilert $^{\circledR}$

Método

Dureza $2340 \mathrm{C}$

Titulação 
Apêndice B - Marcas dos restantes dos equipamentos utilizados na pesquisa

Equipamento Marca

Centrífuga

Estufa

Floteste

Microscópio

Sonda de condutividade

Vórtex
Eppendorf ${ }^{\circledR}$ Centrifuge 5810

FANEM $^{\circledR}$ modelo 320-SE

Ethik Technology modelo Flow Text 218

Olympus ${ }^{\circledR}$ BX51

Go!link

Marconi modelo 162 
Apêndice $\mathrm{C}$ - Características das suspensões de protozoários utilizadas na pesquisa

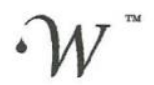

Waterborne ${ }^{\mathrm{TM}}$, Inc. Clinical and Environmental Parasitology Products * 6045 Hurst Street, New Orleans, LA 70118 USA

\section{Product Specification and Analysis Report} Giardia lamblia

Product: Suspension of cysts of Giardia lamblia, H3 isolate, for use in research.

Source of Cysts: Experimentally infected gerbils.

Species/genus identification method(s): Direct immunofluorescence microscopy with genusspecific monoclonal antibodies; also phase microscopy.

\begin{tabular}{|l|l|}
\hline Lot \#: 150601 & Date shed: $6 / 1 / 15$ \\
\hline Total number of cysts provided: $1 \times 10^{6}$ & Date purified: $6 / 1 / 15$ \\
\hline
\end{tabular}

Total volume:<smiles>CO[14CH3]</smiles>

Storage solution:

б PBS with penicillin, streptomycin, gentamicin, $0.01 \%$ Tween 20

O 5\% Formalin/PBS/0.01\% Tween 20

O other: Purification Method(s): Cysts are purified from feces by sucrose and Percoll density gradient
centrifugation.

Quantitation Method(s): Neubauer hemacytometer counting, using red blood cell method.

Storage Condition(s): $4^{\circ}$ Celcius

Expiration Date: Suspensions of live cysts expire 21 days after the date of shipment; formalinized cysts expire 6 months after the date of shipment.

The organisms enclosed in this package are infectious to humans and animals by oral ingestion. The safe handling and disposal of the contents of this package are the responsibility of the recipient. 

Clinical and Environmental Parasitology Products * 6045 Hurst Street, New Orleans, LA 70118 USA
Waterborne TEL / FAX: 504-895-3338 or Toll-Free: 866-895-3338* Ey Products * 6045 Hurst Street, New Orleans, LA 70118 USA $W^{\prime \prime}$

Product Specification and Analysis Report Cryptosporidium parvum

Product: Suspension of Oocysts of Cryptosporidium parvum, Iowa isolate, for use in research.

Source of the oocysts: Experimentally infected calves.

Species/genus identification method(s): Direct immunofluorescence microscopy with genus-specific monoclonal antibodies; also phase microscopy.

\begin{tabular}{|l|l|} 
Lot \#: $10-15$ & Date shed: $5 / 8 / 15$ \\
\hline Total number of oocysts provided: $1 \times 10^{6}$ & Date purified: $5 / 10 / 15$ \\
\hline
\end{tabular}

Total volume:

$$
64 \mathrm{~mL}
$$

$$
\mathrm{O} \mathrm{mL}
$$

other:

Storage solution:

$\varnothing$ PBS with penicillin, streptomycin, gentamicin, Amphotericin B, 0.01\% Tween 20

O 5\% Formalin/PBS \& $0.01 \%$ Tween 20

Other:

Purification method(s): Oocysts are purified from feces by sucrose and Percoll density gradient centrifugation, after initial extraction of feces with diethyl ether.

Quantitation Method: Neubauer hemacytometer counting, using red blood cell method.

Storage Conditions: 4 to 6 degrees Celcius (i.e. refrigerator temperature)

Expiration date: The shelf life of live C. parvum oocysts is guaranteed up to 2 months after the date of shipment; however, viability and useful life of oocysts for research may continue for a much longer period provided oocysts are stored at refrigerator (4-8 deg. C) temperatures in the presence of antibiotics, including Amphotericin B as fungicide ( $0.25 \mathrm{ug}$ per ml). Formalinized oocysts are guaranteed for 6 months after date of receipt.

The organisms enclosed in this package are infectious to humans and animals by oral ingestion. The safe handling and disposal of the contents of this package are the responsibility of the recipient. 
Apêndice D - Características do kit Easyseed ${ }^{\circledR}$

EasySEed $d^{\text {rn }} \quad$ Certificate of Analysis

Batch Number: B 547

$\begin{array}{ll}\begin{array}{l}\text { General } \\ \text { Safety: }\end{array} & \text { This product is non-hazardous. } \\ \text { Storage: } & 2-8^{\circ} \mathrm{C} . \text { Do not freeze. } \\ \text { Catalogue Number: } & \text { ESCG100 } \\ \text { Preparation Date: } & 10 \text { September } 2015 \\ \text { Expiration Date: } & 8 \text { January } 2016 \\ \text { Volume: } & 1.274 \mathrm{ml}+/-21 \text { ul } \\ \text { Suspension media: } & \text { Buffered saline solution. } \\ \text { Sterilisation method: Gamma irradiation. }\end{array}$

\begin{tabular}{|l|c|c|}
\hline $\begin{array}{l}\text { Counts } \\
\text { akthod fet: Esco-001) }\end{array}$ & Mean & St.Dev. \\
\hline Cryptosporidium count: & 99 & 1.4 \\
\hline Giardia count: & 99 & 1.5 \\
\hline DAPl staining: & & \\
\hline Cryptosporidium \% +ve & 100 & $\%$ \\
\hline Giardia \% +ve & 100 & $\%$ \\
\hline
\end{tabular}

Stock specifics

$\begin{array}{ll}\text { Organism: } & \text { Cryptosporidium parvum } \\ \text { Strain: } & \text { lowa } \\ \text { Source: } & \text { Bovine } \\ \text { Shed date: } & 22 \text { August } 2015\end{array}$

Purification method: Discontinuous sucrose and cesium chloride centrifugation gradients.

$\begin{array}{ll}\text { Organism: } & \text { Giardia lamblia } \\ \text { Strain: } & \text { H3 } \\ \text { Source: } & \text { Gerbil } \\ \text { Shed date: } & 27 \text { August 2015 }\end{array}$

Purification method: Sucrose and Percoll density gradient centrifugation

\section{Quality Assurance Officer:}

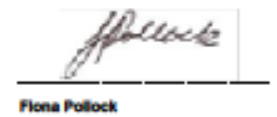

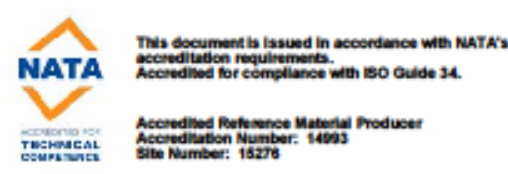

$\because \equiv \mathrm{T}=$

A oidmeracux companr

Water Industry Enquilres:

BTF Pty und

Sychey Australa

Te. 61 (0) 288779150

wnwwbtholo.00m

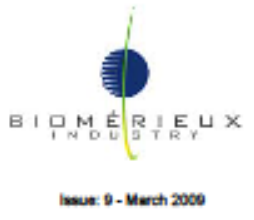


Apêndice E - Orçamentos dos reagentes utilizados para análises de protozoários

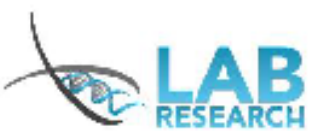

Lab-Research do Brasil Com. de Produtos P/ Pesquisa Ltda.

CNPJ: 07.912.701/0001-46

Av. Itaberaba , 2052 - Sala 11 - Freguesia do Ó

São Paulo - SP CEP - 02739000

Fone: 11-3991-9033 11-3854-8865 - Fax 3976-7157

E-mail: labresearch@labresearch.com.br

\begin{tabular}{|c|c|c|c|c|c|c|c|c|c|}
\hline \multicolumn{2}{|c|}{ DATA } & COTAÇ̃̃o No & VALIDADE & PAGAMEN & ITO & $\begin{array}{l}\text { PEDIDO } \\
\mathbf{N}^{\circ}\end{array}$ & ENTREGA & \multicolumn{2}{|c|}{ REPRESENTANTE } \\
\hline \multicolumn{2}{|c|}{$05 / 10 / 2015$} & $2286-15$ & $\cdots$ & Á VISTA & & $\cdots$ & 45 a 60 dias & \multicolumn{2}{|c|}{ Samanta Costa } \\
\hline \multicolumn{10}{|c|}{$\begin{array}{c}\text { FORMAS DE PAGAMENTOS : Banco Bradesco: Ag. 1756-6 C/C } 31.998-8 \text { - Banco do Brasil Ag. } 6844-6 \text { C/C 1453-2 } \\
\text { Banco Santander: Ag. } 3372 \mathrm{C} / \mathrm{C} 130051500 \text { ou CARTÄO DE CREDITO }\end{array}$} \\
\hline \multicolumn{10}{|c|}{ Registro na Anvisa $N^{\circ} 25351.566930 / 2014-58$} \\
\hline \multicolumn{10}{|c|}{$\begin{array}{c}\text { Devido a instabilidade económica atual, principalmente no que tange ao valor do dólar nossas propostas estáo } \\
\text { valida para compra imediata. }\end{array}$} \\
\hline \multirow{2}{*}{\multicolumn{5}{|c|}{$\begin{array}{l}\text { DADOS DO CLIENTE } \\
\text { Lyda Patricia Sabogal Paz } \\
\text { Profa. Dra, do Departamento de Hidráulica e Saneamento } \\
\text { Escola de Engenharia de São Carlos } \\
\text { Universidade de São Paulo, Brasil. } \\
\text { Tel: (55) (16) } 33739548 \text { Fax: (55) (16) } 33739550\end{array}$}} & \multicolumn{5}{|c|}{ LOCAL DE ENTREGA } \\
\hline & & & & & \multicolumn{3}{|c|}{ LULAL DE LININEGA } & & \\
\hline Item & Qt & Embalagem & Código & \multicolumn{4}{|l|}{ Descrição } & $\begin{array}{r}\text { Preco Unit } \\
\text { (Rs) }\end{array}$ & $\begin{array}{l}\text { Valor Total } \\
\text { (Rs) }\end{array}$ \\
\hline \multirow[t]{4}{*}{01} & 2 & $\begin{array}{c}50 \\
\begin{array}{c}\text { Determinatio } \\
\mathrm{ns}\end{array} \\
\end{array}$ & 250050 & \multicolumn{4}{|c|}{$\begin{array}{l}\text { MERIFLUOR@ Cryptosporidium/Giardia } \\
\text { Marca: MERIDIAN }\end{array}$} & $4.987,00$ & $9.974,00$ \\
\hline & & & & & & \multicolumn{3}{|c|}{$\begin{array}{l}\text { VALOR DOS PRODUTOS (R\$) } \\
\end{array}$} & $9,974,00$ \\
\hline & & & & & & \multicolumn{3}{|c|}{ FRETE (R\$) } & 0,00 \\
\hline & & & & & & \multicolumn{3}{|c|}{ VALOR TOTAL DA PROPOSTA (R\$) } & $9.974,00$ \\
\hline
\end{tabular}

Preços válidos para ordem completa será alterado o valor caso queira cancelar algum item.

\section{Interprise}

At. Doutor Alesmo Mentims Laroca, 20

Jd. Amsrica - Paulmia - SP - CEP: 13140-677

CNPJ: $14.813 .8340001-20-$ IF. 513.057 .482 .114

Fone: 19-3833-6800-Fax: 19-3833 6901

\section{Orçamento}

$N^{\bullet} 0098853 \quad 13 / 10 / 2015$

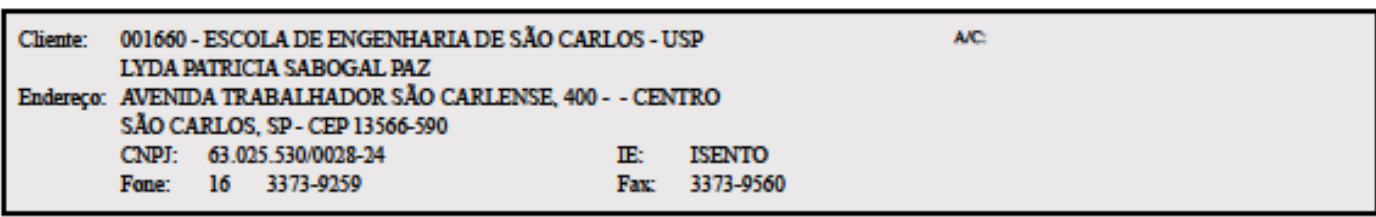

Validade da Proposta: 10 dias Forma de Pagamento: 15 DIAS Moeda:REAL Frete: CIF

\begin{tabular}{|c|c|c|c|c|c|}
\hline Item & Cod. Produto & ON & Quantidade & Unitário & Vend. \\
\hline
\end{tabular}

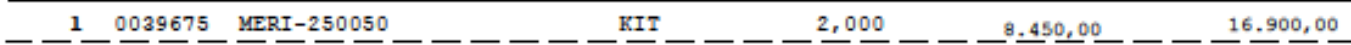

KIT MERIFLUOR CRYPTOSPORIDIUM/GIARDIA - 50 TESTES - MarCa: MERIDIAN BIOSCIENCE - NCM:

2942.00.00- Entrega em ate: 45 dias 
$2905 / 2015$

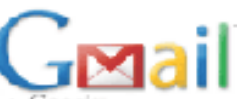

Gmall - cotaçato

Lyda Patricia Sabogal Paz <lysaboga@gmail.com>

\section{cotação}

WMLabnet <wmlabnet (Quol.com.br>

Para: lysaboga@sc.usp.br

29 de maio de 2015 17:37

Prezada Profa. Lyda,

boa tarde!

Em resposta à sua solicitação segue a cotação:

DYNABEADS GC COMBO $5 \mathrm{ml}, 50$ testes (73012) _..RS 23760,00

DYNABEADS GC COMBO 1ml, 10 testes (73012) _..RS 7530,00

Meridian Bioscience ${ }^{m m}$ MeriFluor $^{\mathrm{m}}$ Cryptosporidium/Giardia Test Kit (250050)

1 unidade: R\$ 6200,00

2 unidades: R\$ 11960,00

$07 / 12 / 2015$

Gmall - cotacto

Gmail

Lyda Patricia Sabogal Paz <lysaboga@gmail.com>

cotação

WMLabnet <wmlabnet@uol.com.br>

7 de dezembro de 2015 14:51

Para: Lyda Patricia Sabogal Paz <lysaboga@sc.usp.br>

Prezada Dra. Lyda,

boa tarde!

Segue a cotação solicitada:

EasySeed (ESCG100-PK/10) _..R\$ 4930,00

Kit Merifluor Crypto/Giardia. 50 testes (250050)_.. R\$ 6800,00 
SANBIO CIENTIFICA LTDA.

FUNC: 0008

AV. MAURO KREPSKI 107

JARDIM YPE - PAULINIA - SP - CEP: 13140-542

TEL: (0XX19) 3884-1293 FAX: (0XX19) 3884-1293 CNPJ: 11.326.087/0001-08

IE: $513.468 .358-113$

05/10/15 ORÇAMENTO \# 006919 MR. MANAGER GOLD

IQSC-INSTITUTO DE QUÍMICA DE SÃO CARLOS - 00010

AV. TRAB. SÃO-CARLENSE 400

PARQ ARNOLD SCHMIDT - SÃO CARLOS - SP - CEP: 13566-590

TEL: (OXX16) 3373-9646

DESCRIÇÃO DO PRODUTO

CÓDIGO QUANTIDADE UNIDADE \$UNTTÁRIO SUB-TOTAL

01) MERIFLUOR CRYPTOSPORIDIUM/GIARDIA KIT, 50 TESTS - MARCA: MERIDIAN

$\begin{array}{llll}\text { MERI-250050 } 2 \mathrm{KIT} & \text { R } \$ 7.534,00 & \text { R\$ 15.068,00 }\end{array}$

TOTAL GERAL $->\quad$ R\$ 15.068,00

\begin{tabular}{lc}
\hline VENCIMENTO & VALOR \\
\hline PARA 015 DIAS & $R \$ 15.068,00$
\end{tabular}

FORMA DE ENTREGA: 45/60 DIAS DEVIDO IMPORTAÇÃO DOS USA

OBSERVAÇÕES: PROFa LYDA PATRICIA SABOGAL PAZ

VALIDADE DO ORÇAMENTO: 15/10/15 


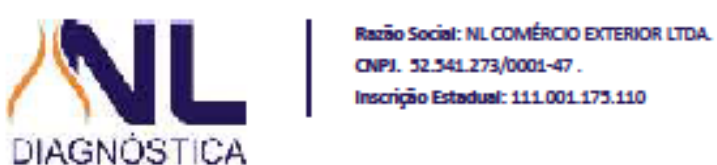

São Paulo, 05 de Outubro de 2015.

PROPOSTA 007-2015

A

Escola de Engenharia de São Carlos

Universidade de São Paulo

A/C: Sra. Lyda Patricia Sabogal Paz

Profe. Dr2. do Departamento de Hidráulica e Saneamento

Tel: (55) (16) 33739548 / Fax: (55) (16) 33739550

E-mail: lysaboga@gmail.com

\begin{tabular}{|c|c|c|c|c|c|}
\hline ITEM & CAT. & DESCRIÇÃOO & QTDE. & $\begin{array}{l}\text { PREÇO } \\
\text { UNIT. }\end{array}$ & $\begin{array}{l}\text { PREÇO } \\
\text { TOTAL }\end{array}$ \\
\hline 01 & 250050 & $\begin{array}{l}\text { Merifluor Cryptosporidium/Giardia - } 50 \text { ensaios } \\
\text { Kit de imunofluorescência direta para a deteç̧äo } \\
\text { simultânea de oocistos do Cryptosporidium spp e } \\
\text { cistos de Giardia spp. Utiliza anticorpos monoclonais } \\
\text { para aumentar a sensibilidade. O procedimento } \\
\text { todo leva uma hora e meia. O kit contem } 25 \text { lâminas } \\
\text { com } 3 \text { cavidades por lâmina. } \\
\text { Marca: Meridian Bioscience }\end{array}$ & $\begin{array}{l}02 \\
\text { KIT }\end{array}$ & $\begin{array}{c}\text { RS 5.250,00 } \\
\text { (Cinco mil, } \\
\text { Duzentos e } \\
\text { Cinquenta } \\
\text { Reais) }\end{array}$ & $\begin{array}{c}\text { RS } \mathbf{1 0 . 5 0 0 , 0 0} \\
\text { (Dez mil e } \\
\text { Quinhentos } \\
\text { Reais) }\end{array}$ \\
\hline
\end{tabular}


SANBIO CIENTIFICA LTDA.

FUNC: 0008

AV. MAURO KREPSKI 107

JARDIM YPE - PAULINIA - SP - CEP: 13140-542

TEL: (0XX19) 3884-1293 FAX: (0XX19) 3884-1293 CNPJ: 11.326.087/0001-08

IE: 513.468.358-113

$19 / 08 / 15 \quad$ ORÇAMENTO \# 007507 MR. MANAGER GOLD

ESCOLA DE ENGENHARIA DE SÃO CARLOS - 00724

AVENIDA TRABALHADOR SANCARLENSE 400

CENTRO - SÃO CARLOS - SP - CEP: 13566-590

CNPJ: 63.025.530/0028-24 IE: ISENTO

\begin{tabular}{|c|c|c|c|}
\hline $\begin{array}{l}\text { DESCRIÇÃO DO } \\
\text { CÓDIGO }\end{array}$ & $\begin{array}{l}\text { PRODUTO } \\
\text { QUANTIDADE UNIDADE }\end{array}$ & \$ UNITÁRIO & SUB-TOTAL \\
\hline \multicolumn{4}{|c|}{ 01) EASYSEED - 10 KIT - MARCA: BTFBIO } \\
\hline BTFB-ESCG100 & $1 \mathrm{KIT}$ & $R \$ 4.043,00$ & $\mathrm{R} \$ 4.043,0$ \\
\hline \multicolumn{3}{|c|}{ TOTAL GERAL --> } & R\$ 4.043,00 \\
\hline
\end{tabular}

PARA 015 DIAS R\$4.043,00

FORMA DE ENTREGA: 45/60 DIAS DEVIDO IMPORTAÇÃO DOS USA

OBSERVAÇÕES: SRA. LYDA PATRICIA SABOGAL PAZ

VALIDADE DO ORÇAMENTO: 31/08/15 
Interprise

ciencia o nos za prioriasa

Atr. Doutor Alesnotro Martins Laroca, 20

Jd. Amsrica - Paulmia - SP - CEP: 13140-677

CNPJ: 72949.4490001-01 - IF 513.026267 .114

Fone: 19-3833-6800 - Fax: 19-3833 6801

\section{Orçamento}

$\begin{array}{ll}N^{\circ} 0097647 & 21 / 08 / 2015\end{array}$

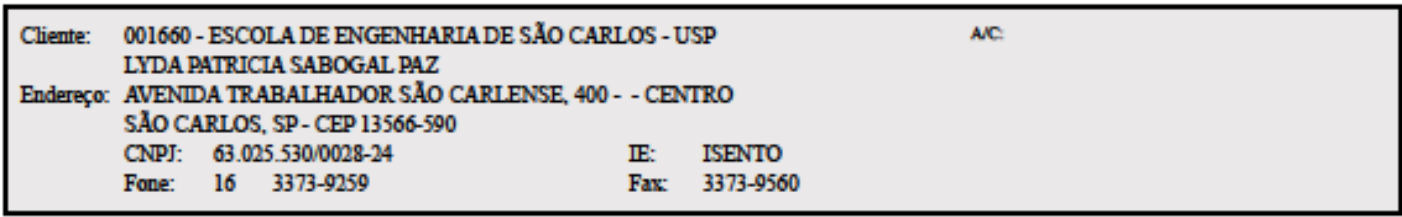

Validade da Proposta: 10 dias Forma de Pagamento: 15 DIAS Moeda: REAL Frete: CIF

\begin{tabular}{|c|c|c|c|c|c|}
\hline Item & Cod. Produto & ons & Quantidade & Unitário & Venda \\
\hline
\end{tabular}

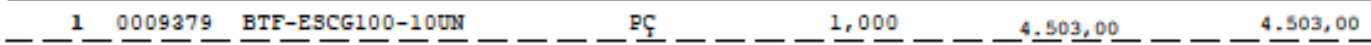
EAsYSEED CG $100-$ CX/10 vials - Marca: BTF BIO - NCM: 2942.00.00- Entrega em ate: 45 dias

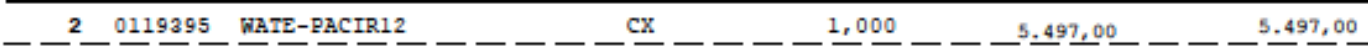
GIARDIA E CRYPTOSPORIDIUM EM SOLUÇAO - 12 vIALs - Marca: WATERBORNE - Entrega em ate: 45 dias

VWR 娄 SOVEREIGN We Enable Science
Orçamento 8302011425 de 28.05.2015

Sovereign Com. de Prod. para Laboratório Ltda

Vossa Referência: A/C Prof ${ }^{a}$ Lyda Patricia Válido desde 28.05.2015 até 07.06.2015

\begin{tabular}{llll}
\hline Item Referência & Quantidade & Preço Unit & Preço S/IPI Tot
\end{tabular}
$10 \quad$ IDEX73012
$1 \times 50$ unid
$1 \times 10.366,50$
$10.366,50$

DYNABEADS GC COMBO $5 \mathrm{ML}$

Preco Unitario: $10.366,50$ BRL DEZ UM MIL TREZENTOS E SESSENTA E SES REAIS CINQÜENTA CENTAVOS

Preco Total: $10.366,50$ BRL DEZ UM MIL TREZENTOS E SESSENTA E SEIS REAIS CINQŪENTA CENTAVOS

ICMS: $18.00 \%$

IPI: $0.00 \%$

Marca: IDEXX LABORATORIES LTD

Prazo de entrega estimado em 60 dias.

NCM code: 3821.00 .00

(EUA) 